\title{
Dynamika procesów politycznych i społecznych w państwach południowej \\ i wschodniej Azji
}

\author{
Redakcja naukowa \\ Joanna Marszałek-Kawa \\ Andrzej Stelmach
}




\author{
Seria \\ Biblioteka Azji i Pacyfiku \\ Redaktor Serii \\ Joanna Marszałek-Kawa \\ Sekretarz Serii \\ Bartosz Ptotka \\ Rada Serii \\ Kamal M. Abdulla (Azerbejdzan), Daulet L. Baideldinov (Kazachstan), \\ Marceli Burdelski (Gdańsk), He Yaomin (Chiny), \\ Hassan A. Jamsheer (Łódź), Vasyl Marchuk (Ukraina), \\ Joanna Marszatek-Kawa (Toruń), Miao Huashou (Chiny), \\ Vladimir I. Nifadiev (Kirgistan), Ewa Oziewicz (Gdańsk), \\ Zdzisław Puślecki (Poznań), Akmal Saidov (Uzbekistan), \\ Grażyna Strnad (Kraków), Peter Vorel (Czechy) \\ Recenzenci tomu \\ prof. dr hab. Zdzisław Puślecki \\ prof. dr hab. Grażyna Strnad \\ Redaktor prowadzący: Daniel Kawa \\ Redakcja techniczna: Ryszard Kurasz \\ Korekta: Zespót \\ Projekt okładki: Krzysztof Galus \\ (C) Copyright by Wydawnictwo Adam Marszałek
}

Wszystkie prawa zastrzeżone. Książka, którą nabyłeś, jest dziełem twórcy i wydawcy. Żadna jej część nie może być reprodukowana jakimkolwiek sposobem - mechanicznie, elektronicznie, drogą fotokopii itp. - bez pisemnego zezwolenia wydawcy. Jeśli cytujesz fragmenty tej książki, nie zmieniaj ich treści i koniecznie zaznacz, czyje to dzieło

Toruń 2020

\title{
ISBN 978-83-8180-491-2
}

VII Międzynarodowy Kongres Azjatycki „Budowanie przyszłości państw: Tradycja,

Teraźniejszość, Przyszłość" - zadanie dofinansowane w ramach umowy

nr DNK/SP/4662466/2020 ze środków Ministra Edukacji i Nauki przeznaczonych na działalność upowszechniającą naukę

Wydawnictwo prowadzi sprzedaż wysyłkową:

tel./fax 56 644 22 35, marketing@marszalek.com.pl

Wydawnictwo Adam Marszałek, ul. Lubicka 44, 87-100 Toruń

tel. 5666422 35, e-mail: info@marszalek.com.pl,www.marszalek.com.pl

Drukarnia, ul. Warszawska 54, 87-148 Łysomice, tel. 566783478 


\section{Spis treści}

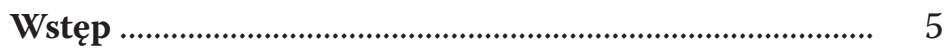

\section{Jerzy Sielski}

Polityczne wzory przywódców współczesnej

władzy w Japonii

\section{Izabela Bojko, Karolina Sówka}

Ewolucja współpracy japońsko-australijskiej

w dziedzinie bezpieczeństwa

35

\section{Tadeusz Detyna}

Perspektywy demograficzne Filipin

\section{Vindensius Adi Gunawan, Janusz Mariański}

Modernizacja społeczna a religie (przypadek

Indonezji)

\section{Kamila Rezmar-Płotka}

Naruszanie wolności religijnej w kontekście demokracji opancerzonej: studium przypadku Indii 


\section{Zbigniew Wiktor, Dorota Jarema}

Kontrowersje ideowo-polityczne w kwestii

chińskiej drogi do socjalizmu

\section{Leszek Krzysztof Sadurski}

Wpływ duńsko-grenlandzkiego konfliktu

o samorządność Grenlandii na współczesne

bezpieczeństwo w euroatlantyckiej części Arktyki 


\section{Wstęp}

Otaczająca nas rzeczywistość zmienia się w zawrotnym tempie. Nie tylko przewartościowaniu ulegają relacje międzypaństwowe, ale zmieniają się uwarunkowania wewnętrzne funkcjonowania poszczególnych państw. Aby nadążyć za dynamiką przemian i zrozumieć zachodzące zjawiska i procesy, należy niejednokrotnie sięgnąć do przeszłości. Poznać genezę, specyfikę i uwarunkowania tego, co dzisiaj obserwujemy jako otaczającą nas rzeczywistość. Główna oś dynamiki współczesnego świata wyraźnie przesuwa się w stronę Azji. Szczególna, ciągle rosnąca rola Chin w gospodarce światowej oznacza również dynamiczny wzrost znaczenia ChRL w polityce międzynarodowej. Ambicje mocarstwowe Państwa Środka znajdują potwierdzenie w rosnącym wpływie Chin w strukturach organizacji międzynarodowych, ekspansji gospodarczej w różnych regionach świata i zacieśnianiu bilateralnych relacji z coraz to nowymi państwami.

W regionie Azji Południowo-Wschodniej zmienia się dynamicznie charakter wzajemnych relacji pomiędzy państwami. W poszczególnych artykułach przedstawiono zarówno uwarunkowania wewnętrzne, genezę, ewolucję i dynamikę zmian w systemie społecznym i politycznym poszczególnych państw, jak i ich reperkusje o charakterze międzynarodowym.

W przedstawionym poniżej zestawie artykułów naukowych znajdzie Czytelnik odniesienia do zarysowanych po- 
wyżej tez. Niekiedy w sposób bezpośredni, w innych przypadkach jako ważny wątek przedstawianych analiz i dociekań naukowych.

W artykule Jerzego Sielskiego Polityczne wzory przywódców współczesnej wtadzy w Japonii zaprezentowano szczegółową analizę politycznych wzorów przywództwa w Japonii. W Kraju Kwitnącej Wiśni tradycyjnie są dwie drogi do władzy politycznej. Pierwsza z nich to kariera biurokratyczna - podążają nią ludzie wywodzący się ze środowiska biurokratycznego. Druga droga to „ludzie partii” - wiedzie ona przez „szczeble” partyjne do władzy państwowej.

Autor rozpatruje problem z perspektywy trzech kryteriów przywództwa: politycznego, kulturowego i ekonomicznego. Ponadto w przywództwie politycznym, w oparciu o czynnik ideologiczno-doktrynalno-programowy, wyróżnia cztery subwzory. W efekcie tworzy cztery typy przywódzców: umiarkowani konserwatyści, liberałowie, rewizjoniści, demokraci/socjaliści. W przywództwie kulturowym wyodrębnia dwa subwzory: „śmierć kulturową” i „korupcję kulturową". Podobnie czyni w przypadku przywództwa ekonomicznego, gdzie wyróżnia dwa subwzorce: „ojciec cudu gospodarczego" oraz Abe Shinzō - wizjoner polityki gospodarczej.

W dalszej części rozważań Autor wyróżnia trzy poziomy walki o władzę. Pierwszym poziomem jest rywalizacja między frakcjami Partii Liberalno-Demokratycznej. Drugi poziom to rywalizacja między politykami, biurokratami i ludźmi biznesu. Trzeci natomiast to układy lokalne między elektoratem, politykami i organizacjami lokalnymi. Te dwa ostatnie poziomy wskazuje Jerzy Sielski to walka nie tylko o poparcie, ale przede wszystkim o pieniądze. Partie w Japonii nie są finansowane przez państwo. To rodzi afery 
i korupcję. Dlatego też japońską politykę nazywa się często "polityką pieniądza" (kinkan seiji).

W kolejnym artykule Ewolucja wspótpracy japońsko-australijskiej $w$ dziedzinie bezpieczeństwa Izabela Bojko i Karolina Sówka przedmiotem badań uczyniły stosunki japońsko-australijskie w dziedzinie bezpieczeństwa. Wskazały na wyjątkowo złożoną i trudną historię stosunków japońsko-australijskich związaną z II wojną światową i ich wpływ na kształt relacji między obydwoma państwami.

Japonia i Australia to jedne z najstabilniejszych demokracji w regionie Azji i Pacyfiku. Od dziesięcioleci podzielają te same wartości oraz wizję globalnego ładu opartego na prawie międzynarodowym. Początkowa współpraca miała ograniczony charakter i cechowała ją niechęć wynikająca z doświadczeń wojennych. Na przestrzeni lat przerodziła się w silne, ważne dla obu stron partnerstwo. Jak można przeczytać w artykule: „Autorki poszukują odpowiedzi na problem badawczy zawarty w pytaniu: jak i dlaczego ewoluowała japońsko-australijska współpraca w dziedzinie bezpieczeństwa?".

Po zakończeniu II wojny światowej Australia optowała za surowym traktowaniem Japonii, jej demilitaryzacją oraz neutralnością. Jednak jeszcze w okresie zimnej wojny, ze względu na korzyści wynikające z wymiany gospodarczej między obydwoma państwami, w 1976 r. podpisano Traktat o przyjaźni i współpracy - Basic Treaty of Friendship and Co-operation between Japan and Australia. Jego celem było podkreślenie przyjaznych relacji między stronami i stworzenie podstaw do rozwijania współpracy w kolejnych obszarach.

Koniec zimnej wojny przyniósł diametralne zmiany w środowisku międzynarodowym. Ogłoszona przez USA 
w kwietniu 1990 r. Wschodnioazjatycka Inicjatywa Strategiczna (East Asia Strategy Initiative, EASI), której celem było ograniczenie obecności wojskowej USA w Azji, zmusiła demokratyczne państwa regionu do zacieśnienia współpracy mającej na celu zwiększenie poczucia bezpieczeństwa. Również dynamiczne zmiany zachodzące w środowisku międzynarodowym w ostatnich latach spowodowały, że współpraca japońsko-australijska wyraźnie się nasiliła.

Kolejne opracowanie to Perspektywy demograficzne Filipin. Jego autor Tadeusz Detyna dokonuje bardzo skrupulatnej i wielowątkowej analizy sytuacji demograficznej jednego z najbardziej dynamicznie zwiększającego swoją populację państwa świata. Jeszcze 150 lat temu w kraju tym żyło ok. $5 \mathrm{mln}$ osób, a obecnie Filipiny liczą ponad $109 \mathrm{mln}$ mieszkańców. Aktualne prognozy wskazują na to, że do 2050 r. Filipiny mają zwiększyć swą liczbę ludności nawet o $42 \mathrm{mln}$. W niedalekiej przyszłości pod tym względem najprawdopodobniej wyprzedzą najpierw Japonię, a potem być może Rosję. Prognozy przewidują, że szczyt populacji Filipiny osiągną około 2100 r., po czym przyrost naturalny zacznie spadać.

Wprawdzie na przestrzeni ostatnich lat naturalny przyrost ludności zdecydowanie wyhamował, jednak nadal jest to ogromne wyzwanie dla władz Filipin. Dziś Filipiny nie są krajem z kilkuprocentowym wzrostu PKB, stając się krajem gwałtownie rosnącym bezrobociem. Jest to także konsekwencja pandemii Covid-19. To również sprawia, że przyszłość demograficzna jest znacznie trudniejsza do przewidzenia - stwierdza Tadeusz Detyna.

Autor wskazuje, iż na demografię Filipin od lat wpływa pozycja Kościoła katolickiego, który w dużej mierze kształtuje system prawny kraju, głównie w zakresie planowania 
rodziny. Niewątpliwie wstydliwym tematem jest nielegalna aborcja, która ma ogromny zasięg. Innymi czynnikami kształtującymi populację Filipin jest spadająca dzietność, powolne starzenie się społeczeństwa oraz ograniczony dostęp do nowoczesnej antykoncepcji.

Tadeusz Detyna wskazuje również na degradację środowiska naturalnego jako przyczynę obniżania się poziomu życia na Filipinach. Szczególnie dotyczy to najuboższych mieszkańców wysp.

Vindensius Adi Gunawan i Janusz Mariański w opracowaniu Modernizacja społeczna a religie (przypadek Indonezji) najpierw określają, czym jest modernizacja społeczna, a następnie szczegółowo analizują relacje modernizacji społecznej i religii. Zasadnicza część opracowania dotyczy historii religii w Indonezji oraz religijności Indonezyjczyków w świetle sondaży opinii publicznej i badań socjologicznych. Modernizacja społeczna, stwierdzają Autorzy artykułu, prowadząca do ponowoczesności wydaje się charakteryzować większość wysoko rozwiniętych społeczeństw współczesnych, a nawet wykazuje pewne znamiona zjawiska ogólnoświatowego. Wiąże się ona często z pluralizacją, indywidualizacją i sekularyzacją jako ważnymi siłami tego procesu oraz detradycjonalizacją jako jej skutkiem. W fazie ponowoczesnej modernizacja niesie ze sobą nie tylko zagrożenia dla religii, ale i pewne nowe szanse związane z odradzaniem się religijności w jej zróżnicowanych kształtach.

Indonezja jest państwem różnorodnym etnicznie, kulturowo, językowo i pod względem religijnym. Zdecydowaną większość jej mieszkańców stanowią muzułmanie (około 88\%). Katolików jest około $3 \%$.

Autorzy stawiają tezę, iż modernizacja społeczna nie prowadzi w Indonezji do coraz bardziej skutecznego usu- 
wania religii z przestrzeni publicznej. Do sytuacji w tym państwie nie pasują teorie socjologiczne, które powstały w europejskim kontekście kulturowym lub co najmniej wymagają znacznej modyfikacji. Religia była i pozostaje jednym z najważniejszych filarów życia publicznego w Indonezji.

Kolejny artykuł pt. Naruszanie wolności religijnej w kontekście demokracji opancerzonej: studium przypadku Indii autorstwa Kamili Rezmer-Płotka także dotyczy sfery religijnej życia społecznego, ale tym razem w Indiach. Autorka stawia tezę, iż Indie tylko formalnie są państwem świeckim. W raportach amerykańskiej Komisji ds. Międzynarodowej Wolności Religijnej (USCIFR) pojawiają się jako jedno z państw, gdzie nagminnie ograniczana i łamana jest wolność religijna. To szczegółowa analiza zawartości raportu tej organizacji z lat 2019-2021 stała się podstawą do odpowiedzi na pytanie, w jaki sposób naruszano wolność religijną w Indiach. Kategorią zastosowaną w badaniu jest demokracja opancerzona, ponieważ ograniczanie wolności religijnej stanowi jeden ze wskaźników mogących świadczyć o występowaniu w danym państwie tego procesu. W Indiach za rządów premiera Narendry Modiego systematycznie ogranicza się wolność mniejszości religijnych, a także dochodzi do prób stworzenia państwa wyznaniowego. W ostatnim raporcie z 2021 r. ponownie wskazano na działania podejmowane przeciwko wyznającym inne religie niż hinduizm, m.in. wykorzystywanie mediów społecznościowych czy innych kanałów komunikacji do szerzenia dezinformacji i nienawiści odnoszącej się do mniejszości takich jak muzułmanie, chrześcijanie czy dalici. Wolność religijna, oprócz tego, że stanowi jedno z podstawowych praw człowieka, może również stanowić jeden ze wskaźników występowania 
w danym państwie procesu opancerzania się demokracji stwierdza Kamila Rezmer-Płotka.

W bardzo obszernym i wnikliwym studium Kontrowersje ideowo-polityczne w kwestii chińskiej drogi do socjalizmu Zbigniew Wiktor i Dorota Jarema dokonują analizy źródeł i ewolucji specyfiki chińskiej drogi do socjalizmu. Przedstawiają uwarunkowania historyczne, ideologiczne i polityczne źródeł, podstaw teoretyczno-ideologicznych i praktycznego wdrażania koncepcji chińskiej drogi do socjalizmu.

Autorzy stwierdzają, iż obecne różnice i rozbieżności między Komunistyczną Partią Chin a innymi partiami komunistycznymi nie są tylko wynikiem wdrożenia i realizacji „socjalistycznej gospodarki rynkowej” przez następcę Mao Zedonga Deng Xiaopinga i kolejne generacje chińskich komunistów, ale mają głębsze przyczyny i uzasadnienie w różnicach rozwoju gospodarczego i kulturalno-cywilizacyjnego Chin, ich odrębnej, liczącej wiele tysięcy lat drogi rozwojowej, które Marks w połowie XIX w. określał jako „azjatycki sposób produkcji” i w związku z tym wszelkie próby przeniesienie rozwiązań oraz instytucji z innych kręgów kulturowych zawodziły i przynosiły fiasko. Chiny musiały poszukiwać własnej drogi do socjalizmu i jego budowy.

Wptyw duńsko-grenlandzkiego konfliktu o samorzadność Grenlandii na współczesne bezpieczeństwo w euroatlantyckiej części Arktyki to tytuł artykułu Leszka Krzysztofa Sadurskiego. Autor porusza w nim problem poszerzenia autonomii Grenlandii jako części składowej królestwa Danii. Analizuje przebieg procesów związanych z poziomem jej samorządności i przewiduje skutki nie tylko dla mieszkańców tej wyspy, ale również dla układu sił w regionie.

Wynikiem dążeń Grenlandczyków do zapewnienia potrzeb związanych z istnieniem własnego samorządu oraz 
możliwości decydowania o własnym losie i kontrolowania zasobów naturalnych znajdujących się na wyspie było uzyskanie statusu autonomii w 1979 r. Zaś w 2009 r. w wyniku referendum przeniesiono na Grenlandczyków dodatkowe kompetencje, związane z zarządzaniem wewnętrznym na wyspie, pozostawiając Kopenhadze jedynie możliwość decydowania w kwestiach obronności, prowadzenia polityki zagranicznej oraz polityki monetarnej.

Grenlandia stanowi ważny komponent bezpieczeństwa euroatlantyckiego w regionie arktycznym. To skutek przynależności Danii do NATO. Konflikt na linii Nuuk-Kopenhaga wpływa na współczesny poziom bezpieczeństwa w tym regionie. Daje on m.in. możliwość wykorzystywania tychże napięć przez Chiny biorące udział w eksploatacji surowców na wyspie. Problematyka artykułu dotyczy przede wszystkim konfliktu duńsko-grenlandzkiego w sprawie zwiększenia samorządności Grenlandii i znacznego ograniczenia zależności tej wyspy od władz Danii. Na tym tle Autor analizuje różne scenariusze, które mogą być konsekwencją tego konfliktu i mieć wpływ na bezpieczeństwo w regionie. Leszek Krzysztof Sadurski przewiduje następujące możliwości: zachowanie obecnego statusu quo, uzyskanie niepodległości przez Grenlandię i wejście pod kuratelę USA, uzyskanie niepodległości przez Grenlandię i wejście pod kuratelę Chin.

Wnioski z badań Autora pokazują, iż relacje między Duńczykami a Grenlandczykami są konfliktogenne. Spory między tymi nacjami są wykorzystywane przez USA i Chiny, które chcą realizować własne interesy w Arktyce. Oddziaływanie konfliktu wpływa negatywnie na bezpieczeństwo struktur NATO.

W szerszym ujęciu euroatlantycki region Arktyki mógłby podnieść potencjał bezpieczeństwa przez głębsze wejście 
mocarstwa, jakim są Stany Zjednoczone. Chociaż z drugiej strony musiałyby one zaangażować więcej swoich sił na tym obszarze, na co niekoniecznie byłyby gotowe.

Joanna Marszałek-Kawa Andrzej Stelmach 



\section{Jerzy Sielski}

Uniwersytet Szczeciński

ORCID ID: https://orcid.org/0000-0002-1900-6870

\section{Polityczne wzory przywódców współczesnej władzy w Japonii}

\section{Wstęp}

Celem pracy jest zaprezentowanie określonych politycznych wzorów przywództwa z perspektywy trzech kryteriów: przywództwa politycznego, kulturowego i ekonomicznego. Ponadto w przywództwie politycznym wyróżniłem cztery subwzory w oparciu o czynnik ideologiczno-doktrynalno-programowy: 1. umiarkowani konserwatyści; 2. liberałowie; 3. rewizjoniści; 4. demokraci/socjaliści. W przywództwie kulturowym przedstawiłem dwa subwzory: „śmierć kulturową" i „korupcję kulturową", podobnie gdy chodzi o przywództwo ekonomiczne mamy dwa subwzorce: „ojciec cudu gospodarczego" oraz Abe Shinzō - wizjoner polityki gospodarczej.

Pomijam w tym tekście rolę cesarza, o którym pisałem w 2017 r. ${ }^{1}$ i skupiłem się na wzorach przywództwa związanych z szefami rządu po II wojnie światowej. Pozostaje jeszcze do wyjaśnienia problem wyróżnienia określonych przywódców jako wzorców do zaprezentowania w tej pracy.

1 J. Sielski, Polityczne wzory przywództwa i władzy w Japonii, [w:] Japońskie realia, red. J. Marszałek-Kawa, T. Bodio, Toruń 2017, s. 9 i n. 
Pierwszy wyróżnik to związek danego przywódcy z analizowanych wzorcem. Przyjąłem zasadę, aby w każdym wzorcu lub subwzorcu było dwóch reprezentantów. Gdy jest ich więcej przywódców, wtedy wchodzi drugi wyróżnik - długość stażu szefa rządu, im dłuższy stażem tym bardziej dany polityk jest wyeksponowany w tej pracy. We wzorcu liberałów został przedstawiony pierwszy premier japoński po II wojnie światowej. Polityk ten nie wyróżniał się długim stażem premierostwa, ale tym, że był pierwszy według mnie warte jest wyeksponowania. Premier Abe został przeze mnie dwa razy wyróżniony, raz jako umiarkowany konserwatysta, drugi jako reprezentant dość głośnej polityki gospodarczej, która nawet w mediach zagranicznych doczekała się swoistej interpretacji i został nazwana „abanomiką"2.

\section{Polityczne wewnętrzne uwarunkowania Japonii po 1945 r.}

Japonia w 1945 r. w wyniku przegranej wojny została okupowana przez Stany Zjednoczone i stała się państwem z gospodarką rynkową. Pierwszy okres po przegranej wojnie (1945-1960) to przetrwanie i reorientacja polityki zarówno wewnętrznej, jak i zagranicznej.

W 1947 r. przyjęto nową Konstytucję sformułowaną przez ludzi gubernatora Japonii gen. Douglasa MacArthura, desygnowanego przez prezydenta USA Trumana.

Cesarz przetrwał, ale stracił swoją boskość, bowiem zgodnie z nową Konstytucją „został symbolem państwa i jedności narodu". Ustanowiono nowy ustrój polityczny demokrację. Wprowadzono system monarchii parlamen-

2 J. Młodawska-Bronowska, Jak wyjść z pułapki wieloletniej stagnacji? Japońskie realia 2016, [w:] ibidem, s. 118 i n. 
tarnej oparty na wzorach brytyjskich, dodając też niektóre elementy władzy typu amerykańskiego.

Shintoizm - rodzimą religię oddzielono od państwa. Uznano ją za jeden z filarów japońskiego militaryzmu, imperializmu i totalitaryzmu oraz czynnik hamujący rozwój demokracji ${ }^{3}$.

System partyjny przechodził różne fazy: ale prawie zawsze na czele lub ma swoich przedstawicieli w rządzie jedna partia. Dlatego też uformował się system partii dominują$\mathrm{cej}^{4}$. Ugrupowaniem tym jest Partia Liberalno-Demokratyczna (PLD) 5 (od 1955 r.) z jednym wyjątkiem (w okresie od września 2009 do 2012 r. na czele stała Demokratyczna Partia Japonii). Od 2012 r. ponownie dominującą była PLD, która zmonopolizowała rynek wyborczy, będąc konglomeratem mniejszych partii prawicowych i centrowych. $Z$ tego też powodu utworzyły się dwie duże frakcje: liberalna i konserwatywna, w ramach których często dochodziło do tworzenia się subfrakcji. W tej ostatniej frakcji można wyróżnić umiarkowanych konserwatystów i rewizjonistów.

3 K. Starecka, Problem rozdziału religii od państwa jako wyraz tendencji do przezwyciężania japońskiego nacjonalizmu po II wojnie światowej, [w:] Różne oblicza nacjonalizmów. Polityka, religia, etos, red. B. Grott, Kraków 2010, s. 490.

4 Zob. S. Greszta-Kowalczuk, Etapy ksztattowania się systemu partyjnego Japonii, 15.06.2010, Centrum Studiów Polska-Azja, http://www. polska-azja.pl/etapy-ksztaltowania-sie-systemu-partyjnego-japonii/ [dostęp: 22.11.2020]: P. Kaczmarek, Partia Liberalno-Demokratyczna w systemie partyjnym po 1993 roku, [w:] Japońskie realia Polityka i gospodarka, red. J. Marszałek-Kawa, T. Bodio, Toruń 2017, s. 28 i n.

5 W polskiej literaturze przedmiotu na temat wewnętrznych uwarunkowań frakcyjności w PLD zab. Karol Żakowski m.in. w: Wewnatrzpartyjne uwarunkowania polityki japońskiej Partii Liberalno-Demokratycznej wobec Chin w latach 1955-2006, Łódź 2012; idem, Przekonania a rzeczywistość. Podziat Partii Liberalno-Demokratycznej na skrzydta liberalne i konserwatywne a japońska polityka zagraniczna, [w:] Meandry japońskiej polityki, red. J. Marszałek-Kawa, Toruń 2012, s. 7-24. 
Zaprezentowana frakcyjność PLD ma też ważną zaletę: gdy następował kryzys na stanowisko premiera powoływano reprezentanta konkurencyjnej frakcji („zasada wahadła”). To działanie polityczne było i jest skuteczną metodą utrzymania przez PLD władzy w państwie. Partia ta nie będąc monolitem, zawsze jednak ma szansę na współtworzenie gabinetu rządzącego. Pozwala to na utrwalenie struktury elit rządzących (przykładem niech będą powiązania członków elity japońskiej: premier Nobusuke Kishi był bratem premiera Eisaku Satō. Natomiast jego córka Yoko Kishi poślubiła Shintarō Abe, który w latach 1982-1986 był ministrem spraw zagranicznych. Ich synem jest Shinzō Abe, który w latach 2006-2007 i 2012-2020 był premierem) i zabezpieczenie kontaktów pomiędzy władzą, biurokracją i biznesem (tzw. żelazny trójkąt władzy). Wynika to z jednej strony z konserwatyzmu konfucjańskiego (tradycjonalizmu), nakazu harmonii w społeczeństwie, jak i także wbudowanych instytucji, które utrudniają dyskurs publiczny, ograniczenia źródeł informacji i konformizmu japońskiego społeczeństwa ${ }^{6}$.

Tradycyjnie są dwie drogi do władzy politycznej - biurokratyczna, a więc ludzie wywodzący się ze środowiska biurokratycznego (zob. drogę premiera Sato). Druga droga to „ludzie partii”, przez „szczeble” partyjne do władzy państwowej.

Politykiem numer jeden w tym systemie politycznym jest premier. Ale jego pozycja polityczna z reguły jest słaba. „Primus Inter Pares". Od 1945 r. było aż 28 premierów, ale tylko siedmiu z nich urzędowało na stanowisku premiera ponad trzy lata. To pokazuje dużą inflację szefów rządu, a zarazem ich słabą pozycję w systemie politycznym.

6 P. Wiszniuk, Obywatel $i$ władza we wspótczesnej Japonii. Wyzwania dla demokracji, Łódź 2017, s. 274. Praca doktorska obroniona na UŁ. 
Dlatego też, przedstawię znaczących premierów z punktu widzenia politycznego, gospodarczego czy kulturowego.

\section{Wzorce polityczne}

\section{Umiarkowani konserwatyści}

Shidehara Kijūrō - okres premierostwa 1945-1946 pierwszy premier - stworzył w październiku 1945 r. nowy rząd przy pomocy amerykańskiego generała Douglasa MacArthura. Jako konserwatywny reformator cieszył się poparciem okupacyjnych władz amerykańskich, które chętnie z nim współpracowały, szczególnie w sprawie rezygnacji z boskiej godności cesarza Hirohito i przy zachowaniu instytucji cesarza jako symbolu suwerenności i jedności Japonii. Shidehara to również autor art. 9 japońskiej Konstytucji, który delegalizował wojnę i zobowiązywał Japonię do nieutrzymywania sił wojskowych.

Koizumi Jun'ichirō - premier 2001-2006 - reformator partyjny i gospodarczy w duchu konserwatywnym. Charyzmatyczna osobowość (został przewodniczącym PLD w wyniku prawyborów wśród wszystkich członków partii). Był mentorem duchowym dla polityków konserwatywnych m.in. Abe Shinzō. Jego przywództwo określano jako „fenomen Koizumiego"7. W wielu sprawach przeciwstawił się własnej partii. Chciał likwidacji powiązań frakcyjnych oraz reform strukturalnych (sprywatyzował pocztę). Stworzono w parlamencie Komisje ds. Konstytucji, które po raz pierwszy skupiły przed-

7 K. Karolak, Proces decyzyjny i wywieranie wptywu w japońskiej polityce na przykładzie rzadów Partii Liberalno-Demokratycznej, [w:] Wspótczesna Japonia. Dylematy $i$ wyzwania, red. J Marszałek-Kawa, K. Skonieczka, Toruń 2014, s. 103. 
stawicieli różnych środowisk politycznych. W wyniku tych działań zmieniono m.in. paragraf 2 art. 9. Od tej pory Armia Samoobrony mogłaby prowadzić akcje na rzecz społeczności międzynarodowej, a na przełomie 2006/2007 Agencja Obrony została zastąpiona Ministerstwem Obrony. Jednak reformy partyjne nie udało się zrealizować.

Abe Shinzō - premier 2006-2007, 2012-2020 - charyzmatyczny wizjoner $w$ duchu konserwatywnym. Zanim został szefem PLD napisał książkę Ku pięknemu krajowi ${ }^{8}$, w której roztaczał przez społeczeństwem wizję „pięknego kraju”. Abe uważał, że należy dostosować dzisiejszą Konstytucję do realiów współczesnych, przede wszystkim uwzględnić problem obronności (rakiety wystrzeliwane z Korei Północnej w kierunku Japonii). Na tym polu Abe wiele zdziałał, twierdząc, że występuje deficyt bezpieczeństwa w systemie prawnym Japonii i zaproponował sposoby naprawienia tej sytuacji ${ }^{9}$. W 2013 r. została przyjęta m.in. Narodowa Strategia Bezpieczeństwa, której celem było wzmocnienie możliwości i roli Japonii w sojuszu z Stanami Zjednoczonymi, poprzez działania dyplomatyczne i współpracy w kwestiach bezpieczeństwa z partnerami dla zachowania pokoju i stabilności ${ }^{10}$. Było to związane z promowaną przez niego ideą proaktywnego pacyfizmu ${ }^{11}$. Oprócz problemów z obronnością Abe pro-

8 Zob. E. Nowicka, „Piękny kraj” Shinzō Abe - japońska wizja przyszłości, [w:] Japonia na początku XXI wieku, red. K. Gawlikowski, M. Ławacz, Toruń 2008, s. 108 i n.

9 A. Ziętek, Kultura strategiczna Japonii, „Teka Komisji Politologii i Stosunków Międzynarodowych” 2016, nr 11/3, s. 29, http:// cejsh.icm.edu.pl/cejsh/element/bwmeta1.element.ojs-doi-10_17951_ teka_2016_11_3_19.

10 National Security Strategy /NSS/, https://www.mofa.go.jp/fp/nsp/ page1we_000081.html [dostęp: 24.11.2020].

11 A. Ziętek, op.cit., s. 24. 
ponował także reformę szkolnictwa, systemu emerytalnego oraz polityki ekonomicznej, tzw. abanomikę. Mimo usilnych starań reformy ekonomiczne i większość reform strukturalnych nie dały oczekiwanych dodatnich efektów w działalności państwa i gospodarki. Z tego też powodu i niezaleczonej choroby ustępuje z urzędu, 16 września 2020 r. Był to polityk najdłużej piastujący stanowisko premiera - ponad dziewięć lat.

\section{Liberałowie}

Yoshida Shigeru - stał na czele urzędu w latach 1946-1947, 1948-1954) - uważany za najwybitniejszego powojennego premiera. Podczas wojny wspierał działania grup anglo-amerykańskich, dlatego też w 1945 r. był więziony przez rząd japoński. Wyznaczony na premiera przez Douglasa MacArthura, współpracował z nim na rzecz odbudowy japońskiej tożsamości: ekonomicznej, politycznej i kulturowej. Był twórcą „doktryny Yosidy”, która przez wiele lat była wyznacznikiem polityki Japonii. Opierała się ona na całkowitej orientacji na współpracę z USA i innymi państwami Zachodu. Partnerstwo z USA opłaciło się. Duży impuls rozwoju gospodarki przyszedł wraz z wojną koreańską. Po zawieszeniu broni w 1953 r. Stany Zjednoczone i państwa Zachodu zdecydowały się na odbudowę Korei Południowej i utrzymaniu tam dużych sił wojskowych. Te wszystkie czynniki potrafił świetnie wykorzystać premier Joshida dla rozwoju gospodarki Japonii, którabędąc blisko geograficznie i politycznie, dostawała zlecenia inwestycyjne i handlowe. „W 1955 roku cała gospodarka Japonii powróciła do poziomu produkcji z połowy lat $30 .{ }^{\prime 12}$.

12 C. Totman, Historia Japonii, tłum. J. Hunia, Kraków 2009, s. 594. 
Wielu po nim premierów przyznawało się do kontynuacji jego myśli politycznej, m.in. Ikeda Hayato, Sato Eisako. Był „przywódcą duchowym” liberalnego skrzydła PLD.

Sato Eisako (okres premierostwa - 1964-1972) - dzialacz pokojowy, przeciwnik broni nuklearnej - laureat Pokojowej Nagrody Nobla (1974).

Sato przebył jedną z dwóch dróg kariery polityka japońskiego zanim został premierem (droga biurokratyczna). Ukończył Uniwersytet Cesarski w Tokio. Potem kolejne szczeble władzy biurokratycznej. 24 lata pracy w Ministerstwie Kolei. Następnie awans na wiceministra transportu (1947-1948). Przełomowym momentem kariery politycznej było stanowisko szefa kancelarii premiera Sihgeru Yosidy (1948). W tymże roku wstąpił do Partii Liberalnej, a potem do Partii Liberalno-Demokratycznej z chwilą jej powstania (1955). Od tego momentu „wspinał” się po szczeblach władzy partyjnej, dochodząc do stanowiska sekretarza generalnego Partii Liberalnej (1950-1954), by potem obejmować stanowiska rządowe, m.in. ministra nauki i technologii, szefa przygotowań do XVIII Olimpiady w Tokio (1963-1964). W listopadzie 1964 r. Hayata Ikeda ustąpił ze stanowiska premiera i na jego miejsce parlament powołał Sato, który w tym czasie był także przewodniczącym PLD. W 1974 r. otrzymał Pokojową Nagrodę Nobla - za rezygnację z opcji atomowej dla Japonii (m.in. w okresie jego premierostwa, przy dużym jego osobistym zaangażowaniu, w 1970 r. Japonia przystąpiła do układu o nierozprzestrzenianiu broni jądrowej) i wysiłku na rzecz pojednania w regionie, m.in. z Koreą Południową ${ }^{13}$.

13 Zob. L. Chmielewska, Eisaku Sato, [w:] Laureaci Pokojowej Nagrody Nobla, red. W. Michowicz, R. Łoś, Łódź 2008, s. 288-290. 


\section{Rewizjoniści (nacjonaliści, jastrzębie)}

Prawicowe skrzydło na prawo od umiarkowanych konserwatystów. Ich główne postulaty to zmiana Konstytucji, szczególności art. 9, rozbudowa sił militarnych, przywrócenie Japonii należytego jej miejsca.

Kishi Nobusuke - premier - 1957-1960 - rewizjonista. W czasie wojny w latach 1941-1942 sprawował funkcję ministra przemysłu i handlu. Za działalność w czasie II wojny światowej był więziony przez aliantów (1945-1948). W 1953 r. powrócił do polityki. Najpierw był ministrem spraw zagranicznych, potem został premierem, a także przewodniczącym Partii Liberalno-Demokratycznej. Jako premier, doprowadził do podpisania układów ze Stanami Zjednoczonymi, a także bezskutecznej próby rewizji pacyfistycznej Konstytucji, co wywołało masowe demonstracje przeciw układowi i jego dymisję. Zwolennik polityki rewizjonistycznej, optował za odbudowę pozycji militarnej Japonii i zajęcia należnego jej miejsca ${ }^{14}$.

Nakasone Yasuhiro - premier 1982-1987 - nacjonalista („jastrząb”). Znany był jako rzecznik zbliżenia japońsko-amerykańskiego, miał dobre kontakty z Ronaldem Reaganem.

Opowiadał się za prywatyzacją. Miał opinię nacjonalisty (porucznik cesarskiej marynarki w czasie wojny) ${ }^{15}$. Chciał rewizji Konstytucji, przede wszystkim art. 9. Głosił hasło „osta-

14 A. Ziętek, op.cit., s. 32.

15 E. Potocka, Japonia w poszukiwaniu nowej pozycji w społeczności międzynarodowej, [w:] Azja Wschodnia na przełomie XX i XXI wieku, red. K. Gawlikowski, we współpracy M. Ławacz, Warszawa 2004, s. 95. 
tecznego rozrachunku z powojenną polityką" ${ }^{16}$. Zwiększył wydatki wojskowe, które w 1987 r. przekroczyły 1\% budżetu. W 1985 r. premier odwiedził chram Yasukuni (miejsce ku czci pamięci japońskich bohaterów wojennych, do grona których zaliczono też niektórych zbrodniarzy wojennych, straconych w 1948 r. na mocy wyroku Międzynarodowego Trybunału Wojskowego dla Dalekiego Wschodu). Spowodowało to negatywny oddźwięk na arenie międzynarodowej, szczególności u sąsiadów: w Chinach i Korei Południowej.

\section{Demokraci/socjaliści}

Tomiichi Murayama - premier 1994-1996 - demokrata-pacyfista. Przywódca Japońskiej Partii Socjaldemokratycznej, a od 1996 r. Japońskiej Partii Socjalistycznej. Jako pierwszy polityk japoński przeprosił za wywołanie II wojny światowej. Opowiadał się przeciwko paktowi bezpieczeństwa ze Stanami Zjednoczonymi, uważając go za niezgodny z pacyfistyczną Konstytucją. Niemniej w czasie swojego urzędowania na stanowisku premiera (był szefem rządu koalicyjnego PLD i SPJ), poparł porozumienie japońsko-amerykańskie oraz uznał Oddziały Samoobrony jako zgodne z Konstytucją. Niemniej nie popierał projektów rewizji art. $9^{17}$.

Hatoyama Yukio - premier 2009-2010 - zwolennik tożsamości azjatyckiej. Przedstawiciel Partii Demokratycznej, który doprowadził ją do największego w historii sukcesu wyborczego. W wyborach parlamentarnych 30 sierpnia

16 K. Żakowski, Przekonania a rzeczywistość..., op.cit.,s. 21.

17 K. Starecka, Ciężar dziewiątego artykutu, [w:] Dzieje Japonii, red. L. Będkowski, „Polityka. Pomocnik Historyczny” 2019, nr 4, s. 106. 
2009 r. jego partia zdobyła 308 z 480 miejsc w Izbie Reprezentantów. PLD przegrała te wybory i przeszła do opozycji. Kampania wyborcza szefa PD opierała się na obiecywaniu zwiększenia świadczeń socjalnych ${ }^{18}$. Miał też odmienne spojrzenie na politykę zagraniczną, uważał, że należy inaczej budować sojusz ze Stanami Zjednoczonymi. Był zwolennikiem azjatyckiej tożsamości politycznej Japonii ${ }^{19}$.

Partia Demokratyczna razem z Partią Socjaldemokratyczną i Nową Partią Ludową we wrześniu 2009 r. utworzyła koalicję rządzącą, co pozwoliło na uzyskanie większości także w izbie wyższej ${ }^{20}$.

W czerwcu 2010 r., po ośmiu miesiącach sprawowania rządów, premier Yukio Hatayoma ogłosił swoją rezygnację ze stanowiska ${ }^{21}$. Była to także porażka Partii Demokratycznej. Główna przyczyną było niespełnienie obietnic wyborczych, nienawiązania odpowiednich relacji z sąsiadami (szczególności z Chinami), nieumiejętne rozwiązania problemów z konsekwencjami trzęsienia ziemi w Tohoku oraz likwidacji lub przeniesienia amerykańskiej bazy wojskowej na wyspie Okinawa, a także poprawy sytuacji gospodarczej $\mathrm{kraju}^{22}$. Dwaj premierzy po Hatoyamie z nadania PD (Naoto Kan i Yoshihko Noda) w swoich wystąpieniach nie wspo-

185 Democratic Party wins landslide in legislative elections, France24, 31.08.2009.

19 A. Ziętek, op.cit., s. 27; Japan's Hatoyama sweeps to power, http:// news.bbc.co.uk/2/hi/asia-pacific/8229988.stm [dostęp: 23.11.2020].

20 Yukio Hatoyama elected as Japan's PM, new cabinet formally launched, http://en.people.cn/90001/90777/90851/6759697.html [dostęp: 23.11.2020].

21 K. Żakowski, Od euforii do rozczarowania. Analiza rząów premiera Hatoyamy Yukio, „Azja-Pacyfik” 2012, t. 15, s. 218 i n.

22 S. Yazawa, Crisis of Democracy In Japan, „Open Democracy”, 16.07.2015, https://wwwopendemocracy.net/shujiro-yazawa/crisis-of-democracy-in-japan [dostęp: 23.11.2020]. 
minali o tożsamości azjatyckiej, orientujący się raczej na wartości zachodnie.

\section{Przywódcy kulturowi}

\section{Kulturowa śmierć}

Obuchi Keizō - premier w latach 1998-2000 - polityk, który wyróżnił się „kulturową śmiercią”. Obuchi zmarł 14 maja 2000 r., była to śmierć w wyniku przepracowania tzw. karōshi. W Japonii według niektórych szacunków ten rodzaj śmierci spotyka 10 tys. osób rocznie. Socjomedyczne zjawisko, związane z nagłym zgonem w wyniku przepracowania i stresu, dotyka zwykle pracowników umysłowych pracujących 60 godzin tygodniowo i niewykorzystujących urlopów. Z kulturowego punktu widzenia ten rodzaj śmierci postrzegany jest jako powód do dumy dla członków rodziny i oznaka człowieka sukcesu ${ }^{23}$.

\section{Kulturowa korupcja}

Kulturowa korupcja polityków wiąże się często z powiązaniami między nimi a Yakuzą. Z tego powodu państwo japońskie dużo traci, ale żaden premier nie potrafił tego problemu rozwiązać ${ }^{24}$.

23 T. Olejniczak, Zarządzanie po japońsku, [w:] Dzieje Japonii..., op.cit., s. 117.

24 A. Fallone, Impuissant Islands: Yakuza Influencing Japanese Sovereignty, https://www.theworldmind.org/home/2018/7/28/impuissant-islands-yakuza-influencing-japanese-sovereignty [dostęp: 27.11.2020]. 
Tanaka Kakuei - premier 1972-1974. W Japonii korupcja zwana jest kozo oshoku (korupcja strukturalna). Polityk ten zasłynął z udowodnionej korupcji. Przez sąd tokijski został uznany winnym (i skazany w 1983 r.) przyjęcia łapówki (4,5 mln dolarów) w okresie pełnienia funkcji premiera od koncernu lotniczego północnoamerykańskiego Lockheed ${ }^{25}$. W Japonii łapówka jest na porządku dziennym wśród elit i szeroko akceptowana. Niemniej jednak przyjął pieniądze od wroga-okupanta, dlatego też została ujawniona. Polityk, mimo skazania, nie „siedział” w więzieniu ze względu na kolejne apelacje, aż do jego śmierci.

Noboru Takeshita - w latach premier 1987-1989. 2 czerwca 1989 r. ustąpił w związku z aferą korupcyjną w Partii Liberalno-Demokratycznej i rządzie (afera z firmą wydawniczą Recruit Co.). Śledztwo w tej sprawie nie potwierdziło udziału w niej premiera, tylko jego pracowników.

\section{Przywódcy polityki gospodarczej}

\section{Ojciec „cudu gospodarczego”}

Ikeda Hayato - premier w okresie 1960-1964 - ojciec cudu gospodarczego Japonii (liberał). Był tym, któremu udało się zrealizować swoje zamierzenia gospodarcze, które rozpoczęły „pochód” Japonii do czołowych miejsc światowej gospodarki. Już nigdy potem, mimo deklarowanych ambitnych programów gospodarczych: Miyazawy Kiichi (premier

25 K. Karolczak, Korupcja strukturalna (koza oshoku) - kinken seiji (polityka pieniądza), [w:] Meandry japońskiej polityki, red. J. Marszałek-Kawa, Toruń 2012, s. 52-54. 
1991-1993) czy Abe Shinzō - (premier 2006-2007, 2012-2020), nie udało się dokonać tego, co uczynił Ikeda.

Był on zwolennikiem ścisłej współpracy gospodarczej i wojskowej ze Stanami Zjednoczonymi. Jest uznawany za jednego z najwybitniejszych autorów japońskiego cudu gospodarczego. Lata sześćdziesiąte to złoty okres gospodarki japońskiej. Wspólny wysiłek na rzecz odbudowy kraju zjednoczył społeczeństwo i stworzył cud gospodarczy. W dużym stopniu było to dziełem Ikedy, który wierzył, że Japonia będzie bogata ${ }^{26}$. Dążył do podwojenia PKB w ciągu dziesięciu lat (w rzeczywistości stało się to już 1967 r.), rozwijając wydatki publiczne, obniżając podatki oraz likwidując bariery dla towarów japońskich na rynkach zagranicznych. W 1962 r. podpisał układ handlowy z ChRL ${ }^{27}$.

\section{Wizjoner polityki gospodarczej}

Abe Shinzō - premier w latach 2006-2007, 2012-2020. W 2013 r. zaprezentował kierunki polityki gospodarczej mającą pobudzić wzrost gospodarczy, czego efektem ma być wyprowadzenie Japonii z długotrwałej stagnacji trwającej już ponad dwie dekady. Polityka ta w światowych mediach została nazwana „abanomiką"

Opierała się ona na trzech filarach, tzw. „trzech strzałach" luzowaniu polityki pieniężnej monetarnej BOJ (Banku Japonii), stymulacji fiskalnej państwa i reformach struktu-

26 C. Andressen, Krótka historia Japonii, tłum. A. Śledzińska, Warszawa 2009, s. 118.

27 K. Żakowski, Przekonania a rzeczywistość..., op.cit., s. 17.

28 J. Młodawska-Bronowska, Jak wyjść z pułapki wieloletniej stagnacji? Japońskie realia 2016, [w:] Japońskie..., op.cit., s. 118 i n. 
ralnych. Niemniej reformy zaproponowane przez premiera nie poprawiły sytuacji ekonomicznej kraju ${ }^{29}$.

\section{Zakończenie}

Jak na wstępie stwierdziłem, że politykiem numer jeden w systemie politycznym Japonii jest szef rządu. W polityce wewnętrznej jego rola jest słaba, ograniczona Konstytucją, szeregiem instytucji czyli biurokracją, zasobami finansowy-mi.

Można wyróżnić trzy poziomy walki o władzę. Rywalizacja między frakcjami PLD jest pierwszym poziomem walki o przywództwo w partii i państwie. Drugi poziom to rywalizacja między politykami, biurokratami i ludźmi biznesu. Trzeci poziom to układy lokalne między elektoratem, politykami i organizacjami lokalnymi. Te dwa ostatnie poziomy to walka nie tylko o poparcie, ale przede wszystkim o pieniądze. Partie w Japonii nie są finansowane przez państwo. To rodzi afery i korupcję. Dlatego też japońską politykę nazywa się „polityką pieniądza” (kinkan seiji) ${ }^{\mathbf{3 0}}$.

W polityce zagranicznej premier ma o wiele większą swobodę manewru, decyduje o kształtowaniu celów polityki zagranicznej „(...) i w jakim kierunku należy ją przekształcić w obliczu nowych wyzwań" ${ }^{31}$. Berger ${ }^{32}$ wprost twierdzi, to

29 Więcej zob. https://businessinsider.com.pl/finanse/makroekono$\mathrm{mia} /$ shinzo-abe-premier-japonii-odchodzi-kim-jest-i-co-zrobil-dla-gospodarki/3g7lgk9 [dostęp: 27.11.2020].

30 K. Karolczak, Korupcja strukturalna (koza ashoku) - kinkan seiji (polityka pieniadza), [w:] Meandry japońskiej..., op.cit., s. 41-68.

31 A. Ziętek, op.cit., s. 27.

32 T.U. Berger, Cultures of Antymilitaryzm: National Security In Germany and Japan, Baltimore 1998, cyt. za: J.S. Lantis, D. Howlett, Kultura strategiczna, [w:] Strategia we wspótczesnym świecie, red. J. Baylis, J. Wirtz, C.S. Gray, E. Cohen, tłum. W. Nowicki, Kraków 2009, s. 99. 
liderzy i elity polityczne tworzą doktryny polityczne, z których wywodzą potem decyzje polityczne „otwierające” nowe wyzwania lub też odnoszą się do starych głęboko zakorzenionych wartości, takich jak multilateralizm czy odpowiedzialność historyczna. Warto tu przypomnieć dwie doktryny japońskie związane z polityką zagraniczną. Pierwszą, tzw. „doktrynę Yosidy”, która przez wiele lat była wyznacznikiem polityki Japonii. Opierała się ona na całkowitej orientacji na współpracę z USA i innymi państwami Zachodu. Partnerstwo z USA opłaciło się Japonii w tym czasie. Ale nowe wyzwania związane $\mathrm{z}$ atakami terrorystycznymi, a także z próbami rakietowymi Korei Północnej, spowodowały zwrot do modernizacji własnej obronności ${ }^{33}$. Przykładem jest tutaj doktryna premiera Abe - proaktywnego pacyfizmu, która dziś jest podstawą zarówno polityki wewnętrznej, jak i zagranicznej.

Z zaprezentowanych premierów można wyróżnić czterech, którzy według mnie spełniają kryteria wybitnych przywódców sceny politycznej w Japonii. To z jednej strony dwaj liberałowie: Yoshida Shigeru i Sato Eisako, po drugiej stronie mamy dwóch konserwatystów: Koizumi Jun'ichirō i Abe Shinzō. Co ciekawe, mamy tutaj relacje mistrz - uczeń. Yoshida był uważany za najwybitniejszego powojennego premiera (19461947, 1948-1954). Sato uważał się za jego ucznia, zdobył sobie duży szacunek i uznanie na arenie międzynarodowej, czego wynikiem było przyznanie mu Pokojowej Nagrody Nobla.

Koizumi zdobył uznanie bezkompromisowością w działaniach politycznych. Jego uczeń Abe przerósł mistrza, uważany jest dziś za mistrza marketingu politycznego, wizjonera, który potrafił przekonać do siebie większość społeczeństwa japońskiego, skutkiem tego rządził Japonią najdłużej ze

33 J. S. Lantis, D. Howlett, Kultura strategiczna..., op.cit., s. 97. 
wszystkich szefów rządu. Obaj politycy konserwatywni, jak i obaj liberałowie to osobowości charyzmatyczne, jedni z najdłużej rządzących premierów, zdobyli sobie charyzmatyczne uznanie w społeczeństwie japońskim.

\section{Bibliografia}

Andressen C., Krótka historia Japonii, tłum. A. Śledzińska, Warszawa 2009.

Berger U.T., Cultures of Antymilitaryzm: National Security In Germany and Japan, Baltimore 1998.

Będkowski L.(red.), Dzieje Japonii, „Polityka. Pomocnik Historyczny" 2019, nr 4.

Democratic Party wins landslide in legislative elections, France24, 31.08.2009.

Fallone A., Impuissant Islands: Yakuza Influencing Japanese Sovereignty, https://www.theworldmind.org/home /2018/7/28/impuissant-islands-yakuza-influencing-japanese-sovereignty.

Gawlikowski K., współpraca M. Ławacz (red.), Azja Wschodnia na przetomie XX i XXI wieku, Warszawa 2004.

Gawlikowski K., Ławacz M. (red.), Japonia na początku XXI wieku, Toruń 2008.

Greszta-Kowalczuk S., Etapy ksztattowania się systemu partyjnego Japonii, 15.06.2010, Centrum Studiów Polska-Azja, http://www.polska-azja.pl/etapy-ksztaltowania-sie-systemu-partyjnego-japonii/.

Grott B. (red.), Różne oblicza nacjonalizmów. Polityka, religia, etos, Kraków 2010.

https://businessinsider.com.pl/finanse/makroekonomia/ shinzo-abe-premier-japonii-odchodzi-kim-jest-i-co-zrobil-dla-gospodarki/3g7lgk9. 
Japan's Hatoyama sweeps to power, http://news.bbc.co.uk/2/ hi/asia-pacific/8229988.stm.

Marszałek-Kawa J. (red.), Meandry japońskiej polityki, Toruń 2012.

Marszałek-Kawa J., Bodio T. (red.), Japońskie realia. Polityka i gospodarka, Toruń 2017.

Marszałek-Kawa J., Skonieczka K .(red.), Wspótczesna Japonia. Dylematy $i$ wyzwania, Toruń 2014.

Michowicz M., Łoś R. (red.), Laureaci Pokojowej Nagrody Nobla, Łódź 2008.

National Security Strategy /NSS/ https://www.mofa.go.jp/ $\mathrm{fp} / \mathrm{nsp} /$ page1we_000081.html.

Totman C., Historia Japonii, tłum, J. Hunia, Kraków 2009.

Yazawa S., Crisis of Democracy In Japan, „Open Democracy”, 16.07.2015, https://wwwopendemocracy.net/shujiro-yazawa/crisis-of-democracy-in-japan.

Yukio Hatoyama elected as Japan's PM, new cabinet formally launched, http://en.people.cn/90001/90777/908 51/6759697.html.

Wiszniuk P., Obywatel $i$ wtadza we wspótczesnej Japonii. Wyzwania dla demokracji, Łódź 2017, praca doktorska obroniona na UŁ.

Ziętek A., Kultura strategiczna Japonii. „Teka Komisji Politologii i Stosunków Międzynarodowych" 2016, nr 11/3, http://cejsh.icm.edu.pl/cejsh/element/bwmeta1.element. ojs-doi-10_17951_teka_2016_11_3_19.

Żakowski K., Od euforii do rozczarowania. Analiza rzadów premiera Hatoyamy Yukio, „Azja-Pacyfik” 2012, t. 15.

Żakowski K., Wewnatrzpartyjne uwarunkowania polityki japońskiej Partii Liberalno-Demokratycznej wobec Chin w latach 1955-2006, Łódź 2012. 


\begin{abstract}
Abstrakt
Celem pracy jest zaprezentowanie określonych politycznych wzorów przywództwa związanych z władzą premiera z perspektywy trzech kryteriów: przywództwa politycznego, kulturowego i gospodarczego. W przywództwie politycznym wyróżniłem cztery subwzory w oparciu o czynnik ideologiczno-doktrynalno-programowy: umiarkowani konserwatyści, liberałowie, rewizjoniści, demokraci/socjaliści. W przywództwie kulturowym przedstawiłem dwa subwzory: „śmierć kulturową" i „korupcję kulturową”. Podobnie, gdy chodzi o przywództwo ekonomiczne, mamy dwa subwzorce: „ojciec cudu gospodarczego" oraz Abe Shinzō - wizjoner polityki gospodarczej.
\end{abstract}

Słowa kluczowe: Japonia, władza premiera, wzory przywództwa politycznego, wzory przywództwa kulturowego, wzory przywództwa polityki gospodarczej

\begin{abstract}
The aim of the work is to present specific political patterns of leadership related to the prime minister's power from the perspective of three criteria: political, cultural and economic leadership. In political leadership, I distinguished four sub-patterns based on the ideological-doctrinal-programmatic factor: moderate conservatives, liberals, revisionists, democrats / socialists. In cultural leadership, I presented two sub-patterns: "cultural death" and "cultural corruption", similarly, when it comes to economic leadership, we have two sub-patterns: the "father of the economic miracle" and Abe Shinzō - a visionary of economic policy.
\end{abstract}

Keywords: Japan, the power of the prime minister, patterns of political leadership, patterns of cultural leadership, patterns of economic policy leadership 


\section{Izabela Bojko}

Uniwersytet Przyrodniczo-Humanistyczny w Siedlcach

ORCID ID: https://orcid.org/0000-0001-8894-2753

Karolina Sówka

Uniwersytet Przyrodniczo-Humanistyczny w Siedllcach

\section{Ewolucja współpracy japońsko-australijskiej w dziedzinie bezpieczeństwa}

\section{Wstęp}

Japonia i Australia to jedne z najstabilniejszych demokracji w regionie Azji i Pacyfiku. Od dziesięcioleci podzielają te same wartości oraz wizję globalnego ładu opartego na prawie międzynarodowym. Początkowa współpraca miała ograniczony charakter i cechowała ją niechęć wynikająca z doświadczeń wojennych. Na przestrzeni lat przerodziła się w silne, ważne dla obu stron partnerstwo.

Celem niniejszego artykułu jest analiza relacji między Japonią i Australią w dziedzinie bezpieczeństwa. Autorki poszukują odpowiedzi na problem badawczy zawarty w pytaniu: jak i dlaczego ewoluowała japońsko-australijska współpraca w dziedzinie bezpieczeństwa? W pierwszej i drugiej części opisano współpracę między Canberrą a Tokio w okresie zimnej wojny i po zimnej wojnie. Trzecia część skupia się na analizie relacji po 2007 r., kiedy to przywódcy obu państw nadali nową jakość intensywnie rozwijającemu się partnerstwu. 


\section{Powojenna wspólpraca japońsko-australijska}

Po zakończeniu II wojny światowej Australia, która została zaatakowana przez obce państwo po raz pierwszy w swojej historii, opowiadała się za surowym traktowaniem Japonii, jej demilitaryzacją oraz neutralnością ${ }^{1}$. W wyniku niekorzystnych zmian zachodzących w środowisku międzynarodowym (m.in. konflikt koreański oraz rewolucja komunistyczna w Chinach) Stany Zjednoczone, które przez pierwszych sześć lat po wojnie okupowały tereny Japonii, zdecydowały, iż oba państwa zostaną związane sojuszem, a japońskie wyspy staną się dalekowschodnią bazą dla wojsk amerykańskich. Takie stanowisko nie zadowalało Canberry. Jednak australijskie obawy o bezpieczeństwo państwa zostały szybko złagodzone przez USA, które zapewniły gwarancje bezpieczeństwa Australii oraz Nowej Zelandii w postaci traktatu ANZUS (Pacific Security Treaty) z 1951 r. ${ }^{2}$

W okresie zimnej wojny współpraca japońsko-australijska koncentrowała się przede wszystkim na sprawach gospodarczych. Kwestie bezpieczeństwa były na dalszym planie relacji między państwami ${ }^{3}$. Po podpisaniu traktatu pokojowego z Japonią przywrócono stosunki dyploma-

1 A. Knap, Naturalny i niezbędny zwrot-azjatycki wektor w polityce zagranicznej Nowej Zelandii, „Gdańskie Studia Azji Wschodniej” 2014, z. 6, s. 157.

2 Y. Ishihara, Japan-Australia security relations and the rise of China: pursuing the "bilateral-plus” approaches, „UNISCI Discussion Papers” 2013, nr 32, s. 83-84.

3 L.J. Ghee, The Australia-Japan Security Relationship: valuable partnership or much ado about nothing much?, „Indo-Pacific Strategic Papers", lisstopad 2015, s. 1, https://www.defence.gov.au/ADC/Publications/documents/IndoPac/2015/Ghee_nov15.pdf [dostęp: 30.11.2020]. 
tyczne oraz otworzono ambasady - australijską w Japonii w 1952 r., a w kolejnym roku japońską w Australii. Pierwsze oficjalne wizyty szefów rządów odbyły się w 1957 r. W kwietniu premier Robert Menzies odwiedził Japonię, natomiast w grudniu premier Kishi Nobusuke - Australię. W tym samym roku podpisano pierwszą umowę handlową - Agreement on Commerce between Japan and the Commonwealth of Australia. Jej zawarcie nie wynikało jednak z nagłego ocieplenia stosunków między państwami (australijska opinia publiczna nadal prezentowała nastroje antyjapońskie), a z pragmatyzmu Australii. Zgodnie z zapisami art. 12 Traktatu Pokojowego w okresie do czterech lat od podpisania dokumentu Japonia zobowiązana była do stosowania klauzuli najwyższego uprzywilejowania (most favoured nation, MFN) w stosunku do stron traktatu ${ }^{4}$, w tym Australii. Po upływie tego okresu Tokio, ze względu na brak stosownych regulacji, miało możliwość wprowadzenia ograniczeń w imporcie towarów australijskich. Byłoby to wysoce niekorzystne dla rozwijającej się gospodarki Australii, dla której rynek japoński stawał się coraz ważniejszy ${ }^{5}$ i tworzył alternatywę dla brytyjskiego, skupiającego się coraz bardziej na Europie ${ }^{6}$. Wypracowanie porozumienia było istotne również dla Japonii, bowiem była to pierwsza dwustronna

4 Treaty of Peace with Japan (with two declarations). Signed at San Francisco, on 8 September 1951, https://treaties.un.org/doc/Publication/UNTS/Volume\%20136/volume-136-I-1832-English.pdf [dostęp: 30.11.2020].

5 M. Sprengel, Gospodarczo-polityczne wspótczesne relacje Australii z Japonią. Wzorzec dla stosunków międzynarodowych $w$ regionie Azji i Pacyfiku, Kraków 2012, s. 157.

6 Trading with the enemy: the Australia-Japan Agreement on Commerce, https://www.abc.net.au/radionational/programs/rearvision/trading-with-the-enemy-the-australia-japan/3393730 [dostęp: 30.11.2020]. 
umowa handlowa zawarta po wojnie i stanowiła ważny krok w kierunku odbudowy japońskiej gospodarki oraz kreowania wizerunku zaufanego partnera ${ }^{7}$.

Rosnąca współpraca gospodarcza oraz podzielanie obaw związanych z polityką azjatycką USA za prezydentury Richarda Nixona (ograniczanie obecności Stanów Zjednoczonych w Azji) ${ }^{8}$, sprzyjały poszerzaniu relacji japońsko-australijskich o kolejne płaszczyzny. Podczas zimnej wojny głównym obszarem kooperacji w zakresie bezpieczeństwa była współpraca wywiadowcza, ustanowiona z inicjatywy Australii. Początkowo miała ona charakter tajny, jednak z czasem zaczęto rozważać oficjalne porozumienie z japońskim wywiadem. W efekcie, w drugiej połowie lat 70. podpisano dwa porozumienia': między Australijską Tajną Służbą Wywiadowczą (Australian Secret Intelligence Service, ASIS) i japońskim Urzędem Wywiadu i Badań Rady Ministrów (Naikaku jōhō chōsashit, Naichō) oraz australijską Połączoną Organizacją Wywiadu (Joint Intelligence Organisation, JIO) i Japońską Agencją Obrony (Bōeishō).

W 1972 r. podpisano Agreement between the Government of the Commonwealth of Australia and the Government of Japan for Co-operation in the Peaceful Uses of Atomic Energy. Dokument dotyczył kwestii związanych z promowaniem pokojowego użycia energii atomowej, uwzględniał wymianę ekspertów oraz jawnych informacji (unclassified information), wymianę sprzętu, obiektów, materiałów i usług w celu

7 Ibidem.

8 E.G. Ravenal, The Nixon Doctrine and Our Asian Commitments, https://www.foreignaffairs.com/articles/asia/1971-01-01/nixon-doctrineand-our-asian-commitments [dostęp: 30.11.2020].

9 D. Ball, Whither the Japan-Australia security relationship?, https:// nautilus.org/apsnet/0632a-ball-html/ [dostęp: 30.11.2020]. 
pokojowego wykorzystania energii atomowej ${ }^{10}$. Dekadę po sygnowaniu umowy, w marcu 1982 r., podpisano Agreement between the Government of Australia and the Government of Japan for Co-operation in the Peaceful Uses of Nuclear Energy. W części głównej porozumienie zawierało treści zbliżone do wcześniejszej umowy. Nowy dokument zawierał trzy aneksy dotyczące: a) poziomów ochrony fizycznej;

b) ponownego przetwarzania materiałów jądrowych oraz c) reaktorów jądrowych ${ }^{11}$.

Ze względu na korzyści wynikające $\mathrm{z}$ wymiany gospodarczej między Tokio a Canberrą w 1976 r. (po trzech latach negocjacji) podpisano Traktat o przyjaźni i współpracy Basic Treaty of Friendship and Co-operation between Japan and Australia. Jego celem było podkreślenie przyjaznych relacji między stronami, stworzenie podstaw do rozwijania współpracy w kolejnych obszarach (m.in. politycznym, społecznym, kulturowym) ${ }^{12}$ oraz wzmocnienie powiazań in-

10 Agreement between the Government of the Commonwealth of Australia and the Government of Japan for Co-operation in the Peaceful Uses of Atomic Energy (Canberra, 21.02.1972), http://www.austlii.edu. $\mathrm{au} / \mathrm{au} /$ other/dfat/treaties/ATS/1972/9.html?stem $=0 \&$ synonyms $=0 \&$ query=Agreement $\% 20$ between $\% 20$ the $\% 20$ Government $\% 20$ of $\% 20 J a p a n \% 20$ and\%20the\%20Government\%20 of\%20Australia\%20for\%20Co-operation\%20in\%20the\%20Peaceful\%20Uses\%20of\%20Nuclear\%20Energy\%20 when\%20was\%20signed [dostęp: 30.11.2020].

11 Agreement between the Government of Australia and the Government of Japan for Co-operation in the Peaceful Uses of Nuclear Energy (Canberra, 5.03.1982), http://www.austlii.edu.au/cgi-bin/sinodisp/ $\mathrm{au} /$ other$/ \mathrm{dfat} /$ treaties/ATS $/ 1982 / 22$ html? stem $=0 \&$ synonyms $=0 \&$ query=Agreement $\% 20$ between\%20the\%20Government $\% 20$ of $\% 20$ Japan $\% 20$ and $\% 20$ the $\% 20$ Government $\% 20$ of $\% 20$ Australia $\% 20$ for $\% 20$ Co-operation\%20in\%20the\%20Peaceful\%20Uses\%20of\%20Nuclear\%20Energy\%20 when\%20was\%20signed\#fn0 [dostęp: 30.11.2020].

12 Basic Treaty of Friendship and Co-operation between Australia and Japan, https://www.dfat.gov.au/geo/japan/Pages/basic-treaty-of-friendship-and-co-operation-between-australia-and-japan [dostęp: 30.11.2020]. 
stytucjonalnych (institutional linkages). Dokument ten stanowił podłoże dla przyszłej współpracy między państwami, a także umożliwiał renegocjację dotychczasowych umów, co nadawało mu charakter traktatu parasolowego (umbrella treaty $)^{13}$.

Relacje japońsko-australijskie w latach 1950-1990 obejmowały również fora wielostronne związane z tworzeniem regionalnych mechanizmów współpracy i przyczyniły się m.in. do utworzenia w 1989 r. Wspólnoty Gospodarczej Azji i Pacyfiku (APEC) $)^{14}$.

\section{Relacje japońsko-australijskie po zimnej wojnie}

Koniec zimnej wojny przyniósł diametralne zmiany w środowisku międzynarodowym. Mimo malejącej groźby globalnego konfliktu nuklearnego, niepokój społeczności międzynarodowej w dalszym ciągu budziły: konflikt na Półwyspie Koreańskim i program nuklearny Korei Północnej, konflikt w Cieśninie Tajwańskiej czy proliferacja broni masowego rażenia. Obawy sojuszników Waszyngtonu wiązały się również z ogłoszoną w kwietniu 1990 r. Wschodnioazjatycką Inicjatywą Strategiczną (East Asia Strategy Initiative, EASI), której celem było ograniczenie obecności wojskowej USA w Azji. Japonia i Australia podjęły działania mające na celu zwiększenie ich zaangażowania w zapewnianie bezpieczeństwa regionalnego oraz nawiązanie współpracy z innymi państwami

13 M. Dee, Friendship and co-operation: the 1976 Basic Treaty between Australia and Japan, Australia 2006, s. 13, https://www.dfat.gov.au/ sites/default/files/basic-treaty-between-australia-and-japan.pdf [dostęp: 30.11.2020].

14 Y. Ishihara, op.cit., s. 84. 
regionu $^{15}$. Pierwszymi oznakami rosnącego zaangażowania było wsparcie przez oba państwa koalicji antyirackiej podczas I wojny w Zatoce Perskiej (1990-1991). Australia wysłała w miejsce misji dwa niszczyciele i jeden statek dostawczy, a także zapewniła wsparcie wywiadowcze, pomoc w usuwaniu min i wsparcie medyczne dla wielonarodowych sił pod dowództwem USA ${ }^{16}$. Japonia natomiast, ze względu na ograniczenia związane z działalnością Sił Samoobrony (SDF), przekazała pomoc finansową w wysokości 13 mld \$. Mimo dużego wkładu w misję społeczność międzynarodowa krytykowała Japonię za działania zbyt małe, zbyt późne ${ }^{17}$. Zrodziło to frustrację japońskiego rządu, który zaczął podejmować kroki w celu umożliwienia Siłom Samoobrony uczestnictwa w misjach zagranicznych. Po zakończeniu konfliktu Japonia zdecydowała się na wysłanie niszczycieli min w rejon Zatoki Perskiej (kwiecień-wrzesień 1991 r.). Udział Japończyków w rozminowywaniu Zatoki okazał się sukcesem i początkiem zmian w japońskiej polityce bezpieczeństwa ${ }^{18}$.

W 1992 r. Japonia po raz pierwszy w historii wzięła udział w operacji pokojowej (PKO). Jednostki SDF wysłane do Kambodży znalazły się pod dowództwem porucznika armii australijskiej generała Johna Sandersona. Pozytywne doświadczenia wynikające ze współpracy stały się impulsem dla rozwoju i wzmocnienia bilateralnych relacji między państwami. Australia z zadowoleniem postrzegała zmiany

15 T. Satake, J. Hemmings, Japan-Australia security cooperation in the bilateral and multilateral contexts, „International Affairs” 2018, nr 94 (4), s. 819.

16 Ibidem, s. 819.

17 A. Sado, The End of the Cold War and Japan's Participation in Peacekeeping Operations: Overseas Deployment of the Self-Defense Forces, "Japan's Diplomacy Series" 2015, nr 638, s. 2-5.

18 Ibidem, s. 2-5. 
zachodzące w japońskim zaangażowaniu w kwestie bezpieczeństwa regionalnego i podobnie jak Cesarstwo dążyła do dalszego wzmacniania kooperacji. Elementem świadczącym o rosnącym znaczeniu partnerstwa było umieszczenie Australii w opublikowanej w 1997 r. Białej Księdze Obronności Japonii (Defense of Japan) w sekcji państw, z którymi Japonia blisko współpracuje na płaszczyźnie bezpieczeństwa. W kolejnych latach oba państwa współdziałały podczas misji PKO w Timorze Wschodnim (2000 r.), w Sudanie Południowym (2012 r.) oraz podczas misji w Iraku (2004 r.) ${ }^{19}$.

Ważnym obszarem współpracy australijsko-japońskiej jest pomoc humanitarna i pomoc w przypadku katastrof (HA/ DR). W 2004 r., po uderzeniu tsunami w część Azji Południowo-Wschodniej, Japonia, Australia, Stany Zjednoczone i Indie utworzyły grupę, której zadaniem było zapewnienie niezbędnej pomocy oraz podstawowego zaopatrzenia na obszarze dotkniętym katastrofą. Prawdziwym testem dla kooperacji w tym zakresie okazało się wsparcie udzielone przez Australię po tsunami, które uderzyło w największą japońską wyspę - Honsiu w 2011 r. Australijczycy wysłali wówczas zespół poszukiwawczo-ratowniczy, trzy Boeingi C-17 oraz trzy zdalnie sterowane pompy wodne. Australijskie Siły Obronne (ADF) były - obok sił amerykańskich - najbardziej zaangażowane w udzielanie pomocy Japończykom ${ }^{20}$. Państwa współpracowały także podczas niesienia pomocy Filipińczykom po przejściu tajfunu Haiyan (2013 r.) oraz poszukiwań wraku malezyjskiego samolotu, który zaginął w marcu $2014 \mathrm{r}^{21}$

19 Y. Ishihara, op.cit., s. 84.

20 Ibidem, s. 82.

21 Prime Minister Shinzo Abe's Interview with The Australian "Special relationship" between Australia and Japan begins July $8^{\text {th }} 2014$, https:// www.mofa.go.jp/p_pd/ip/page4e_000114.html [dostęp: 30.11.2020]. 
Nie bez znaczenia dla rozwijającej się współpracy japońsko-australijskiej było utworzenie, wraz ze Stanami Zjednoczonymi, w 2002 r. Trójstronnego Dialogu Strategicznego (Trilateral Strategic Dialogue, TSD) będącego pierwszym formalnym trójstronnym mechanizmem bezpieczeństwa w regionie Azji i Pacyfiku². W 2006 r. Dialog zinstytucjonalizowano, ustalono, że spotkania przedstawicieli państw członkowskich będą odbywać się na poziomie ministerial$n^{23}{ }^{23}$. Głównym celem powołanego mechanizmu jest koordynacja stanowisk politycznych obejmujących kwestie regionalne, pogłębianie współpracy między stronami Dialogu (w obszarach bezpieczeństwa i obrony), wymiany informacji wywiadowczych, kwestiach pomocy rozwojowej oraz HA/ DR. Dialog ten umożliwił wzmocnienie relacji trójstronnych między członkami. O ile w momencie powstania stosunki dwustronne i współpraca w zakresie bezpieczeństwa między USA a Japonią oraz USA a Australią posiadały solidne podstawy i były uważane za jedne z najważniejszych wzajemnych relacji dla tych państw, o tyle relacja japońsko-australijska stanowiła najstabsze ogniwo trójkąta strategicznego ${ }^{24}$. W kwietniu kolejnego roku, w celu wzmocnienia Trójstronnego Dialogu Strategicznego utworzono Forum Bezpieczeństwa i Współpracy Obronnej (SDCF). W przeciwieństwie do TSD, nowo powstała inicjatywa została powołana do poprawy interoperacyjności taktycznej i strategicznej mię-

22 A. Shearer, U.S.-Japan-Australia strategic cooperation in the trump era: Moving from Aspiration to Action, [w:] South East Asia Affairs 2017, red. D. Singh, M. Cook, Singapore 2017, s. 83.

23 K. Ashizawa, Australia-Japan-U.S. trilateral strategic dialogue and the ARF. Extended bilateralism or a new minilateral option?, [w:] Cooperative Security in the Asia-Pacific: The ASEAN Regional Forum, red. J. Haacke, N.M. Morada, London 2010, s. 92.

24 A. Shearer, op.cit., s. 83. 
dzy armią australijską, japońską oraz amerykańską, a także zwiększenia dostępu do zasobów wywiadowczych i technologicznych ${ }^{25}$.

\section{Nowa jakość współpracy po 2007 r.}

Rosnące zaufanie między Japonią i Australią przyczyniło się do podpisania w marcu 2007 r. Wspólnej Deklaracji Współpracy w dziedzinie Bezpieczeństwa (Joint Declaration on Security Cooperation, JDSC). Dokument podpisany przez premierów Shinzō Abe i Johna Howarda stał się znaczącym krokiem w kierunku budowania pokoju i bezpieczeństwa w regionie oraz stworzył podstawy dla dalszego rozwoju współpracy obu państw na płaszczyźnie politycznej i wojskowej $^{26}$. Sfera polityczna obejmuje spotkania w tzw. formacie $2+2$ (ministrów obrony i spraw zagranicznych obu państw). Australia stała się drugim państwem - po USA, z którym Japonia prowadzi tego typu dialog. Pierwsze spotkanie w tej formule odbyło się 6 czerwca 2007 r. w Tokio. We wspólnym komunikacie ministrowie obu państw potwierdzili, iż rola „partnerstwa strategicznego w ostatnich latach znacznie wzrosła, a stosunki dwustronne nigdy nie były silniejsze"27. Podkreślono również, że łączą ich wspólne wartości, takie jak demokracja oraz dążenie do zapewnienia pokoju i stabilności w regionie ${ }^{28}$. W kolejnych latach zorga-

25 T. Satake, J. Hemmings, op.cit., s. 825.

26 Y. Ishihara, op.cit., s. 85.

27 Japan-Australia Joint Foreign and Defence Ministerial Consultations Joint Statement 2007, https://www.mofa.go.jp/region/asia-paci/ australia/joint0706.html [dostęp: 30.11.2020].

28 Ibidem. 
nizowano kilka spotkań ${ }^{29} \mathrm{w}$ formacie $2+2$, ostatnie odbyło się 10 października 2018 r. w Sydney. Sfera wojskowa współpracy japońsko-australijskiej obejmuje wspólne ćwiczenia wojskowe, takie jak Nichi Gou Trident, których celem jest ułatwienie współdziałania w operacjach morskich ${ }^{30}$. Obok wspólnych ćwiczeń wojskowych, Japonia i Australia brały również udział w ćwiczeniach organizowanych we współpracy z USA, np. ćwiczenia lotnicze Cope North Guam w $2011 \mathrm{r}^{31}$

W 2007 r. premier Japonii Shinzō Abe zaproponował utworzenie Czterostronnego Dialogu Bezpieczeństwa (Quatrilateral Secutiry Dialogue, QUAD), obejmującego Japonię, Australię, USA i Indie. Inicjatywa powstała w odpowiedzi na rosnącą potęgę Chin. Ponadto miała na celu wzmocnienie dialogu między państwami, ustanowienie efektywnej współpracy oraz promocję wspólnych wartości w Azji ${ }^{32}$. Niestety współdziałanie w ramach tej Inicjatywy nie powiodło się i wkrótce została zawieszona. Pod koniec 2007 r. premierem Australii został sceptycznie do niej nastawiony Kevin Rudd, który nie ukrywał, iż podczas swoich rządów będzie dążył do wzmacniania więzi z Chinami ${ }^{33}$.

29 Australijsko-japońskie spotkania w formule $2+2$ odbywały się w latach: 2008, 2010, 2012, 2014, 2015, 2017, 2018.

30 Australia-Japan bilateral exercise concludes, https://news.navy. gov.au/en/Apr2016/Fleet/2878/Australia-Japan-bilateral-exercise-concludes.htm\#.XdrWo9XdjIU [dostęp: 30.11.2020].

31 T. Satake, J. Hemmings, op.cit., s. 830.

32 A. Rai, Quadrilateral Security Dialogue 2 (Quad 2.0) - a credible strategic construct or mere "foam in the ocean"?, "Maritime Affairs: Journal Of The National Maritime Foundation Of India" 2018, vol. 14, nr 2, s. 139.

33 A. Singh, India-Australia relations: Getting over the Quad blues, https://www.lowyinstitute.org/the-interpreter/india-australia-relations-getting-over-quad-blues [dostęp: 30.11.2019]. 
Dodatkowym katalizatorem rozpadu QUAD'u stała się decyzja Australii, która, aby nie narażać się na niezadowolenie Chin, odmówiła sprzedaży uranu Indiom.

W kolejnych latach rządzący zarówno w Japonii, jak i w Australii skupiali się głównie na utrzymaniu władzy i kwestiach wewnętrznych, poświęcając mniej uwagi sprawom zagranicznym ${ }^{34}$. Nie wiązało się to jednak z pogorszeniem relacji między Tokio a Canberrą. W oficjalnych dokumentach strategicznych obu państw podkreślano znaczenie partnerstwa. Biała Księga Obronności Australii z 2009 r. określiła Japonię jako kluczowego partnera strategicznego ${ }^{35}$ w regionie. Z kolei Japonia w opublikowanych rok później National Defense Program Guidelines zauważyła, iż doszło do zmiany równowagi sił na świecie oraz wzrostu potęgi Chin, Rosji i Indii, na co odpowiedzią powinno stać się wzmacnianie współpracy i zacieśnianie relacji z demokracjami podzielającymi te same wartości, takimi jak Austra$\operatorname{lia}^{36}$.

Coraz mocniejsze więzy łączące Japonię i Australię w zakresie bezpieczeństwa pozwoliły na podpisanie szeregu umów. W 2010 r. zawarto umowę nabycia i wzajemnych Usług (Acquisition and Cross Servicing Agreement, ACSA). Dokument wszedł w życie trzy lata później i dotyczy logistyki

34 S.W. Harold, D. Grossman, B. Harding (i in.), The Thickening Web of Asian Security Cooperation: Deepening Defense Ties Among U.S. Allies and Partners in the Indo-Pacific, s. 32, https://www.rand.org/content/ $\mathrm{dam} / \mathrm{rand} /$ pubs/research_reports/RR3100/RR3125/RAND_RR3125.pdf [dostęp: 30.11.2019].

35 Defending Australia in the Asia Pacific Century: Force 2030, s. 95, https://www.defence.gov.au/whitepaper/2009/docs/defence_white_paper_2009.pdf [dostęp: 30.11.2019].

36 National Defense Program Guidelines for FY 2011 and beyond, s. 3-4, https://www.mod.go.jp/e/d_act/d_policy/pdf/guidelinesFY2011. pdf [dostęp: 30.11.2019]. 
- określa ramy współpracy między państwami w kwestiach, takich jak: operacje pokojowe, ćwiczenia i szkolenia, HA/ DR czy transport ludności w sytuacjach wyjątkowych ${ }^{37}$. Dla Japonii umowa tego typu była pierwszą podpisaną z innym państwem niż USA. Ze względu na charakter powiązań w zakresie bezpieczeństwa łączących Tokio z Waszyngtonem oraz Tokio z Canberrą, umowy różniły się pod względem sytuacji, w których miały zastosowanie oraz wykazem towarów i wzajemnych usług ${ }^{38}$. Na skutek zmian w japońskim ustawodawstwie w 2015 r., będących wynikiem polityki proaktywnego pacyfizmu oraz poszerzenia roli i zdolności SDF, przywódcy obu państw zdecydowali się na uaktualnienie ACSA w 2017 r. Zaktualizowana umowa rozszerza katalog sytuacji, w których możliwa jest wymiana dóbr i usług między państwami ${ }^{39}$. Przewiduje m.in. możliwość udostępnienia amunicji podczas ćwiczeń czy operacji HA/DR, a nie jak do tej pory wyłącznie żywności czy surowców ${ }^{40}$. W 2012 r. podpisano kolejną ważną dla bilateralnej współpracy umowę o bezpieczeństwie informacji (Information Security Agreement, ISA). Dokument ułatwił wzajemne udostępnianie informacji niejawnych i ustanowił nowe procedury niezbędne dla ich ochrony ${ }^{41}$.

37 The Signing of the Japan-Australia Acquisition and Cross-servicing Agreement (ACSA), https://www.mofa.go.jp/announce/announce/2010/5/0519_02.html [dostęp: 30.11.2020].

38 Zob. szerzej: Y. Ishihara, Japan-Australia Defence Cooperation in the Asia-Pacific Region, s. 102, http://www.nids.mod.go.jp/english/publication/joint_research/series10/pdf/06.pdf [dostęp: 30.11.2020].

39 Defense of Japan 2018, s. 357, https://www.mod.go.jp/e/publ/w_ paper/pdf/2018/DOJ2018_Full_1130.pdf.

40 P. Parameswaran, Why the New Japan-Australia Military Pact Matters. A closer look at the significance of the signing of a new defense pact, https://thediplomat.com/2017/01/why-the-new-japan-australiamilitary-pact-matters/ [dostęp: 30.11.2020].

41 Y. Ishihara, Japan-Australia Defence Cooperation in the Asia-Pa- 
W 2014 r. premierzy Shinzō Abe i Tony Abbott nadali nowe znaczenie partnerstwu, podnosząc je do rangi specjalnego partnerstwa strategicznego. We wspólnym komunikacie podkreślono, iż oba państwa „łączy wieloletnia i głęboka przyjaźń (...) oparta na wspólnych wartościach i strategicznych interesach, w tym demokracji, prawach człowieka, praworządności, otwartych rynkach i wolnym handlu"42. W tym samym roku podjęto również pierwsze negocjacje w celu podpisania umowy o wzajemnym dostępie (Reciprocal Access Agreement, RAA). Jest ona istotna dla Japonii, ponieważ będzie wzorem dla kolejnych tego typu porozumień z innymi państwami. RAA związana jest z ustanowieniem ram prawnych do prowadzenia działań na obcej ziemi. Dotyczy kwestii, takich jak opodatkowanie, zasady wjazdu i wyjazdu personelu wojskowego i sprzętu, jurysdykcja karna oraz reagowanie na nieszczęśliwe wypadki. Przedłużające się negocjacje między Canberrą a Tokio oraz brak porozumienia w kwestii ostatecznego kształtu umowy wynikały z obecności kary śmierci w katalogu środków karnych, które mogą zostać użyte wobec australijskiego żołnierza, który popełnił, wymagającą szczególnego potępienia, zbrodnię na terenie Japonii. Australijski rząd nie zgadzał się na narażanie obywatela na karę śmierci, ponieważ jest to niezgodne z obowiązującym prawem (kara śmierci została zniesiona w 1985 r. $)^{43}$. Podpisanie dokumentu

cific Region, s. 102, http://www.nids.mod.go.jp/english/publication/joint_ research/series10/pdf/06.pdf [dostęp: 30.11.2020].

42 Prime Minister Abbott and Prime Minister Abe Joint Statement "Special Strategic Partnership for the $21^{\text {st }}$ Century", s. 1, https://www.mofa. go.jp/files/000044543.pdf [dostęp: 30.11.2020].

43 M.M. Bosack, Blazing the way forward in Japan-Australia security ties, https://www.japantimes.co.jp/opinion/2019/04/15/commentary/ japan-commentary/blazing-way-forward-japan-australia-security-ties/\#. XdwK19XdjIU [dostęp: 30.11.2020]. 
przyczyni się do usprawnienia organizacji wspólnych ćwiczeń i operacji wojskowych oraz do zwiększenia interoperacyjności między SDF i ADF. Po sześciu latach negocjacji rządy obu państw osiągnęły konsensus w tej sprawie. W listopadzie 2020 r. podczas wizyty premiera Morrisona w Tokio (był pierwszym przywódcą przyjętym przez premiera Yoshihide Sugę po objęciu urzędu) liderzy poinformowali o wypracowaniu porozumienia ${ }^{44}$.

Przedłużające się negocjacje dotyczące RAA nie stanowiły przeszkody dla dalszego wzmacniania więzi na płaszczyźnie bezpieczeństwa i obronności między państwami. Na przełomie września i października 2019 r. japońscy i australijscy piloci myśliwców wzięli udział w ćwiczeniach Bushido Guardian obywających się w Japonii. Joe Iervasi, wicemarszałek Royal Australian Air Force (RAAF) stwierdził, iż „ćwiczenie (...) daje Australii i Japonii możliwości nie tylko przetestowania i oceny istniejącej interoperacyjności, ale także zwiększenia wzajemnej świadomości na temat wymagań w zakresie projekcji siły, w tym przebazowania dalekiego zasięgu"45. W 2020 r. zaplanowano, że Japonia (po raz pierwszy) weźmie udział w australijskich ćwiczeniach Pitch Black, jednakże ze względu na rozprzestrzenianie się COVID-19 zostały one odwołane ${ }^{46}$.

Oprócz zaawansowanej współpracy bilateralnej i trójstronnej (z USA) w 2017 r. wznowiono rozmowy w ramach

44 Verdict still out on Morrison's whirlwind Tokyo trip, https://www. eastasiaforum.org/2020/11/23/verdict-still-out-on-morrisons-whirlwindtokyo-trip/ [dostęp: 7.01.2021].

45 Bushido Guardian 19, https://www.altair.com.pl/news/view? news_id=29051 [dostęp: 7.01.2021].

46 CANCELLED - Exercise Pitch Black 2020, https://www.airforce.gov.au/news-and-events/events/general/cancelled-exercise-pitchblack-2020 [dostęp: 7.01.2021]. 
Czterostronnego Dialogu Bezpieczeństwa. W listopadzie na marginesie Szczytu ASEAN (ASEAN Summit) w Manili odbyło się spotkanie przywódców Japonii, Australii, USA i Indii. Pomimo braku wspólnego komunikatu zdecydowano - po niemal dekadzie - o reaktywacji QUAD-u, określanego QUAD-em 2.0. Podczas listopadowych rozmów skupiono się na tematach, takich jak: poszanowanie prawa międzynarodowego, bezpieczeństwo morskie, zagrożenie ze strony Korei Północnej, kwestie nieproliferacji BMR, terroryzm oraz swoboda żeglugi ${ }^{47}$. Nie ulega wątpliwości, że nowe otwarcie QUAD-u wiąże się z asertywnym i budzącym niezadowolenie zachowaniem Chin w regionie, w kwestii Morza Południowochińskiego, zasiedlania sztucznych wysp oraz nierespektowania prawa międzynarodowego ${ }^{48}$. O ponownym przyłączeniu się do Dialogu Canberry zdecydowała ponadto chęć budowania bliższych stosunków gospodarczych i strategicznych z Indiami.

W kolejnych latach członkowie Dialogu spotykali się kilkakrotnie. 26 września 2019 r. przy okazji 74. sesji Zgromadzenia Ogólnego ONZ w Nowym Jorku odbyło się pierwsze spotkanie QUAD-u na szczeblu ministerialnym, do tej pory odbywały się na niższym poziomie i miały miejsce tylko w Azji. Potwierdzono wówczas zaangażowanie na rzecz wolnego i otwartego Indo-Pacyfiku opartego na wspólnych wartościach i poszanowaniu prawa międzynarodowego ${ }^{49}$. O wzroście znaczenia współpracy między czterema naj-

47 A. Rai, op.cit., s. 140.

48 D. Zdziech, Quad-Australia. Nowe otwarcie, „Krakowskie Studia Międzynarodowe" 2018, vol. XV, nr 4, s. 228.

49 A. Panda, US, India, Australia, Japan 'Quad' Holds Senior Officials Meeting in Bangkok. The "quad" continues its consultative process, https://thediplomat.com/2019/11/us-india-australia-japan-quad-holdssenior-officials-meeting-in-bangkok/ [dostęp: 14.12.2019]. 
większymi demokracjami Azji świadczy również zaproszenie Australii (po trzynastu latach) do udziału w ćwiczeniach morskich Malabar $2020^{50}$.

\section{Podsumowanie}

Dynamiczne zmiany zachodzące w środowisku międzynarodowym w ostatnich latach spowodowały, że współpraca japońsko-australijska nabrała tempa. Pierwotnie ograniczona do wymiany informacji i wzajemnych wizyt, ostatecznie przybrała formę, często określaną mianem quasi-sojuszu. Niechęć będąca pokłosiem II wojny światowej została zastąpiona współpracą. Początkowo oba państwa angażowały się w przedsięwzięcia służące zapewnianiu pokoju i bezpieczeństwa międzynarodowego. Wraz z zakończeniem zimnej wojny oraz wzrostem obaw o amerykańską obecność w regionie i asertywną postawę Chin, decydenci w Tokio i Canberrze dostrzegli korzyści wynikające z tejże współpracy również dla podniesienia ich własnego poziomu bezpieczeństwa narodowego.

W 2013 r. australijski premier Tony Abbott określił Japonię mianem najlepszego przyjaciela w Azji (best friend in Asia). Określenie to potwierdza nie tylko znaczenie partnerstwa między państwami, pokazuje również jak bardzo - na przestrzeni ostatnich 70 lat - ewoluowały relacje japońsko-australijskie.

50 Pierwotnie ćwiczenia Malabar (przeprowadzane w Zatoce Bengalskiej lub na Pacyfiku) były wspólnymi ćwiczeniami marynarek indyjskiej i amerykańskiej. W 2014 r. zostały one rozszerzone na ćwiczenia trójstronne $\mathrm{z}$ udziałem JSDF. 


\section{Bibliografia}

Agreement between the Government of Australia and the Government of Japan for Co-operation in the Peaceful Uses of Nuclear Energy (Canberra, 5.03.1982).

Agreement between the Government of the Commonwealth of Australia and the Government of Japan for Co-operation in the Peaceful Uses of Atomic Energy (Canberra, 21.02.1972).

Ashizawa K., Australia-Japan-U.S. trilateral strategic dialogue and the ARF. Extended bilateralism or a new minilateral option?, [w:] Cooperative Security in the Asia-Pacific: The ASEAN Regional Forum, red. J. Haacke, N.M. Morada, London 2010.

Australia-Japan bilateral exercise concludes, https://news. navy.gov.au/en/Apr2016/Fleet/2878/Australia-Japan-bilateral-exercise-concludes.htm\#.XdrWo9XdjIU.

Ball D., Whither the Japan-Australia security relationship?, https://nautilus.org/apsnet/0632a-ball-html/.

Basic Treaty of Friendship and Co-operation between Australia and Japan.

Bosack M.M., Blazing the way forward in Japan-Australia security ties, https://www.japantimes.co.jp/opinion/2019/04/15/commentary/japan-commentary/blazing-way-forward-japan-australia-security-ties/\#.Xdw K19XdjIU.

Bushido Guardian 19, https://www.altair.com.pl/news/view? news_id=29051.

CANCELLED - Exercise Pitch Black 2020, https://www.airforce.gov.au/news-and-events/events/general/cancelled-exercise-pitch-black-2020.

Dee M., Friendship and co-operation: the 1976 Basic Treaty between Australia and Japan, Australia 2006, https:// 
www.dfat.gov.au/sites/default/files/basic-treaty-between-australia-and-japan.pdf.

Defending Australia in the Asia Pacific Century: Force 2030, https://www.defence.gov.au/whitepaper/2009/docs/defence_white_paper_2009.pdf.

Defense of Japan 2018, https://www.mod.go.jp/e/publ/w_ paper/pdf/2018/DOJ2018_Full_1130.pdf.

Ghee L.J., The Australia-Japan Security Relationship: valuable partnership or much ado about nothing much?, "Indo-Pacific Strategic Papers", listopad 2015, https:// www.defence.gov.au/ADC/Publications/documents/IndoPac/2015/Ghee_nov15.pdf.

Harold S.W., Grossman D., Harding B. (et al.), The Thickening Web of Asian Security Cooperation: Deepening Defense Ties Among U.S. Allies and Partners in the Indo-Pacific, https://www.rand.org/content/dam/rand/pubs/ research_reports/RR3100/RR3125/RAND_RR3125.pdf. Ishihara Y., Japan-Australia Defence Cooperation in the Asia-Pacific Region, http://www.nids.mod.go.jp/english/ publication/joint_research/series10/pdf/06.pdf.

Ishihara Y., Japan-Australia security relations and the rise of China: pursuing the "bilateral-plus” approaches, „UNISCI Discussion Papers" 2013, nr 32.

Japan-Australia Joint Foreign and Defence Ministerial Consultations Joint Statement 2007, https://www.mofa.go.jp/ region/asia-paci/australia/joint0706.html.

Knap A., Naturalny i niezbędny zwrot - azjatycki wektor w polityce zagranicznej Nowej Zelandii, „Gdańskie Studia Azji Wschodniej" 2014, z. 6.

National Defense Program Guidelines for FY 2011 and beyond, https://www.mod.go.jp/e/d_act/d_policy/pdf/ guidelinesFY2011.pdf. 
Panda A., US, India, Australia, Japan 'Quad' Holds Senior Officials Meeting in Bangkok. The "quad" continues its consultative process, https://thediplomat.com/2019/11/ us-india-australia-japan-quad-holds-senior-officials-meeting-in-bangkok/.

Parameswaran P., Why the New Japan-Australia Military Pact Matters. A closer look at the significance of the signing of a new defense pact, https://thediplomat. com/2017/01/why-the-new-japan-australia-military-pact-matters/.

Prime Minister Abbott and Prime Minister Abe Joint Statement "Special Strategic Partnership for the 21st Century", https://www.mofa.go.jp/files/000044543.pdf.

Prime Minister Shinzo Abe's Interview with The Australian "Special relationship" between Australia and Japan begins July 8th 2014, https://www.mofa.go.jp/p_pd/ip/page4e_000114.html.

Rai A., Quadrilateral Security Dialogue 2 (Quad 2.0) a credible strategic construct or mere "foam in the ocean”?, „Maritime Affairs: Journal Of The National Maritime Foundation Of India" 2018, vol. 14, nr 2.

Ravenal E.G., The Nixon Doctrine and Our Asian Commitments, https://www.foreignaffairs.com/articles/ asia/1971-01-01/nixon-doctrine-and-our-asian-commitments.

Sado A., The End of the Cold War and Japan's Participation in Peacekeeping Operations: Overseas Deployment of the Self-Defense Forces, „Japan's Diplomacy Series” 2015, nr 638.

Satake T., J. Hemmings, Japan-Australia security cooperation in the bilateral and multilateral contexts, "International Affairs" 2018, nr 94 (4). 
Shearer A., U.S.-Japan-Australia strategic cooperation in the trump era: Moving from Aspiration to Action, [w:] South East Asia Affairs 2017, red. D. Singh, M. Cook, Singapore 2017.

Singh A., India-Australia relations: Getting over the Quad blues, https://www.lowyinstitute.org/the-interpreter/india-australia-relations-getting-over-quad-blues.

Sprengel M., Gospodarczo-polityczne wspótczesne relacje Australii z Japonią. Wzorzec dla stosunków międzynarodowych w regionie Azji i Pacyfiku, Kraków 2012.

The Signing of the Japan-Australia Acquisition and Crossservicing Agreement (ACSA), https://www.mofa.go.jp/ announce/announce/2010/5/0519_02.html.

Trading with the enemy: the Australia-Japan Agreement on Commerce, https://www.abc.net.au/radionational/programs/rearvision/trading-with-the-enemy-the-australia-japan/3393730.

Treaty of Peace with Japan (with two declarations). Signed at San Francisco, 8.09.1951.

Verdict still out on Morrison's whirlwind Tokyo trip, https:// www.eastasiaforum.org/2020/11/23/verdict-still-out-on-morrisons-whirlwind-tokyo-trip/.

Zdziech D., Quad-Australia. Nowe otwarcie, „Krakowskie Studia Międzynarodowe” 2018, vol. XV, nr 4.

\begin{abstract}
Abstrakt
Przedmiotem badań w niniejszym artykule są stosunki japońsko-australijskie w dziedzinie bezpieczeństwa oraz ich ewolucja. Trudna historia stosunków japońsko-australijskich związana z II wojną światową wpłynęła na kształt relacji między państwami. W okresie zimnej wojny współpraca między Tokio a Canberrą utrzymywała
\end{abstract}


się na niskim poziomie. Impulsem do pogłębienia relacji stały się zmiany zachodzące w środowisku międzynarodowym obu państw oraz dostrzeżenie wzajemnych korzyści płynących ze współpracy. Celem artykułu jest analiza relacji japońsko-australijskich w dziedzinie bezpieczeństwa z uwzględnieniem ich uczestnictwa $\mathrm{w}$ dialogach wielostronnych.

Słowa kluczowe: Japonia, Australia, bezpieczeństwo, bezpieczeństwo międzynarodowe

\begin{abstract}
The subject of research in this article is the Japanese-Australian security relationship and its evolution. The difficult history of Japanese-Australian relations connected with World War II significantly influenced the development of relations in the field of security between the countries. During the Cold War cooperation between Tokyo and Canberra was low. The changes taking place in the international environment of both countries and the perception of the mutual benefits of cooperation have become an impulse to deepen relations. The aim of the article is to analyze Japanese-Australian relations in the field of security, including their participation in multilateral dialogues.
\end{abstract}

Keywords: Japan, Australia, security, international security 


\section{Tadeusz Detyna}

Uniwersytet Opolski

\section{Perspektywy demograficzne Filipin}

W latach 70. ubiegłego wieku Wacław Zbyszewski, polski emigracyjny publicysta, współpracownik Rozgłośni Polskiej Radia Wolna Europa, w jednym z felietonów z cyklu „Wędrówki po Europie" podkreślał przeludnienie północnych Włoch, wskazując głównie na gęstą zabudowę oraz wszechobecną infrastrukturę komunikacyjną. To subiektywne odczucie jest z pewnością nieobce milionom turystów odwiedzających ten kraj, szczególnie pochodzącym z państw znacznie rzadziej zaludnionych.

Jest na Pacyfiku archipelag o powierzchni niemal identycznej jak Włochy, czyli kraj nieco mniejszy od Polski - Filipiny. Jego populacja w 1986 r. zrównała się z liczbą mieszkańców Włoch, by dynamicznie odskoczyć, osiągając obecnie ponad $109 \mathrm{mln}$ mieszkańców (dane dla Włoch to „jedynie” ponad $60 \mathrm{mln}$ ). Co pewien czas w mediach pojawiają się alarmistyczne informacje o setkach uchodźców z Afryki na wyspie Lampedusie, którzy są ogromnym wyzwaniem, szczególnie że z pewnością pojawią się kolejne fale nielegalnych imigrantów.

Aktualne prognozy wskazują na to, że do 2050 r. Filipiny mają zwiększyć swą liczbę ludności nawet o prawie $42 \mathrm{mln}$. To tak jakby cała populacja Polski oraz Litwy przeniosła się w tym czasie na terytorium Włoch. Dla państwa włoskiego byłby to niewyobrażalny koszmar, a tymczasem taka wła- 
śnie jest perspektywa demograficzna Filipin. Nie będą to oczywiście uchodźcy z Afryki ani Polacy z Litwinami, lecz Filipińczycy, którzy muszą gdzieś mieszkać, którym trzeba będzie w lepszym lub gorszym stopniu zapewnić wyżywienie, zaopatrzenie w wodę pitną, edukację, ochronę zdrowia, zatrudnienie itd. - i to w sytuacji i tak już dużej gęstości zaludnienia - na obecnym poziomie między Belgią a Holandią dla całego kraju. Tyle że w Belgii czy Holandii eksplozja demograficzna to już odległa przeszłość.

Może wydać się dziwne, że Filipinom ma przybyć $42 \mathrm{mln}$ obywateli, skoro drastycznie spadła dzietność, a zatem przyrost naturalny istotnie spowolnił, lecz matematyki nie da się oszukać, więc nawet ten zredukowany przyrost, biorąc pod uwagę obecny stan wyjściowy i tzw. procent składany - wywołuje takie perspektywiczne efekty. Jeżeli oczywiście nie wystąpią jakieś nieprzewidziane wydarzenia i procesy, a prognozy zasadniczo okażą się trafne.

W 2020 r. liczba ludności Filipin urosła o 1597000 i osiągnie 111303000 ludzi pod koniec 2021 r. Migracja ludności w ostatnich latach zmniejsza populację o ok. 100 tys. rocznie, uwzględniając saldo emigracji i imigracji (w tym reemigracji). Były lata, w których to saldo wynosiło ok. 130 tys., a nawet znacznie więcej. Średnia liczba urodzeń na Filipinach wynosi ponad $2 \mathrm{mln} 440$ tys. rocznie, liczba zgonów to ponad 720 tys. Przyrost naturalny wyniesie w 2021 r. około 1,48\% (różne szacunki nieznacznie różnią się od siebie). Nastąpi wzrost o 1594000 mieszkańców, mimo ponad 700 tys. zgonów. W 2022 r. liczba ludności ma osiągnąć 112902 000. Od 1980 r. gęstość zaludnienia Filipin uległa zmianie z 159 na ponad 360 osób na km². W 2050 r. nastąpi zwiększenie gęstości zaludnienia do 507,4 osób na kilometr kwadratowy. Gęstość zaludnienia przewyższy za- 
tem obecny wskaźnik dla Korei Południowej (aktualnie taką gęstość zaludnienia posiada polskie miasto Zielona Góra).

Struktura społeczna Filipin wskazuje na podział 54566 tys. kobiet oraz 55137 tys. mężczyzn, co daje średnio 1011 mężczyzn na 1000 kobiet. Rozkład wiekowy populacji: 40,4\% ludności (44 363 893) poniżej 20. roku życia, 54,4\% ludności (59667 462) pomiędzy dwudziestym a 64. rokiem życia oraz 5,2\% osób (5 682615 ) powyżej 65. lat.

Według większości szacunków w 2050 r. liczba ludności ma wzrosnacć do 151 mln 293 tys. osób. Szacowana długość życia w chwili urodzenia wyniesie wówczas 73,6 lat (69,9 lat dla mężczyzn i 77,4 lat dla kobiet). Utrzymywać się będzie jeszcze przez lata lekka liczebna przewaga mężczyzn nad kobietami.

Liczba mieszkańców filipińskich miast wzrosła z 37400857 (48,0\%) w 2000 r. do 48555000 (44,3\%) w 2020 r., a zatem $\mathrm{w}$ ujęciu procentowym dokonała się dezurbanizacja kraju, gdyż wieś charakteryzuje się wyższą dzietnością, a przemieszczanie się ludności ze wsi do miast jest mimo wszystko ograniczone. Wielu Filipińczyków przekonało się bowiem, że zamieszkanie w mieście nie gwarantuje lepszych perspektyw. Wybierają zatem pozostanie na obszarze wiejskim. Mimo to w przyszłości przewiduje się wzrost wskaźnika urbanizacji.

Tabela 1. Ludność Filipin na przestrzeni lat

\begin{tabular}{|l|c|c|c|c|c|}
\hline \multicolumn{1}{|c|}{ Rok } & Ludność & Przyrost & Średnia wieku & Dzietność & Gęstość na $1 \mathrm{~km}^{2}$ \\
\hline 1960 & 26273025 & $3,3 \%$ & 21,9 & 7,15 & 88 \\
\hline 1965 & 30913933 & $3,1 \%$ & 21,7 & 6,78 & 104 \\
\hline 1970 & 35804729 & $2,8 \%$ & 21,8 & 6,26 & 120 \\
\hline 1975 & 41295124 & $2,8 \%$ & 22,0 & 5,72 & 138 \\
\hline 1980 & 47396968 & $2,7 \%$ & 22,3 & 5,18 & 159 \\
\hline 1985 & 54323648 & $2,7 \%$ & 22,7 & 4,71 & 182 \\
\hline
\end{tabular}




\begin{tabular}{|l|c|c|c|c|c|}
\hline 1990 & 61947348 & $2,5 \%$ & 23,1 & 4,32 & 208 \\
\hline 2000 & 77991569 & $2,1 \%$ & 24,4 & 3,81 & 262 \\
\hline 2010 & 93726624 & $1,6 \%$ & 26,7 & 3,16 & 314 \\
\hline 2015 & 101716359 & $1,6 \%$ & 27,6 & 2,96 & 341 \\
\hline 2020 & 109703000 & $1,5 \%$ & 28,4 & 2,81 & 368 \\
\hline 2021 & 111303000 & $1,4 \%$ & 28,6 & - & 373 \\
\hline
\end{tabular}

Źródło: opracowanie na podstawie: https://www.populationof. net/pl/philippines/ [dostęp: 17.01.2021]. Dane dotyczą końca podanych lat.

W 1866 r. całkowita populacja Filipin liczyła 4411261 (dane szacunkowe). Gęstość zaludnienia wynosiła wówczas ok. 15 osób na km², przypominając współczesną Norwegię. Na przestrzeni pond 150 lat dokonał się zatem gigantyczny, wręcz skokowy wzrost populacji. W ostatnich 60. latach jest to wzrost wręcz ponadczterokrotny. Jednakże dzietność oraz stopa przyrostu sukcesywnie spadają. Rośnie zatem średnia wieku dla całej populacji (28,6 lat), choć i tak można ciągle mówić o bardzo młodym społeczeństwie (średni wiek populacji Włoch to 45,7 lat, ale jest to drugie najstarsze społeczeństwo na świecie). Dla Polski wiek ten na przestrzeni 60 lat wzrósł z 29,1 lat do 42,2. Można zatem stwierdzić, że średni wiek populacji Filipin przypomina Polskę z 1960 r.

Tabela 2. Przewidywana liczba ludności 2025-2050

\begin{tabular}{|c|c|c|c|c|c|c|c|}
\hline Rok & Populacja & $\begin{array}{c}\text { Zmiana } \\
\text { roczna }\end{array}$ & Migracja & $\begin{array}{c}\text { Średnia } \\
\text { wieku }\end{array}$ & Dzietność & $\begin{array}{c}\text { Gęstość } \\
\left(\mathrm{os}^{2} / \mathrm{km}^{2}\right)\end{array}$ & $\begin{array}{c}\text { Populacja } \\
\text { miejska }\end{array}$ \\
\hline 2025 & 117665000 & $\begin{array}{c}1579000 \\
(1,3 \%)\end{array}$ & -90 tys. & 29,3 & 2,67 & 395 & $\begin{array}{c}52850000 \\
(44,9 \%)\end{array}$ \\
\hline 2030 & 125372000 & $\begin{array}{c}1512000 \\
(1,2 \%)\end{array}$ & -90 tys. & 30,3 & 2,55 & 421 & $\begin{array}{c}58096000 \\
(46,3 \%)\end{array}$ \\
\hline 2035 & 132668000 & $\begin{array}{c}1421000 \\
(1,1 \%)\end{array}$ & -90 tys. & 31,2 & 2,44 & 445 & $\begin{array}{c}64357000 \\
(48,5 \%)\end{array}$ \\
\hline 2040 & 139448000 & $\begin{array}{c}1312000 \\
(0,9 \%)\end{array}$ & -90 tys. & 32,1 & 2,34 & 468 & $\begin{array}{c}71256000 \\
(51,1 \%)\end{array}$ \\
\hline
\end{tabular}




\begin{tabular}{|c|c|c|c|c|c|c|c|}
\hline 2045 & 145665000 & $\begin{array}{c}1197000 \\
(0,8 \%)\end{array}$ & -90 tys. & 33,0 & 2,25 & 489 & $\begin{array}{c}78200000 \\
(53,7 \%)\end{array}$ \\
\hline 2050 & 151293000 & $\begin{array}{c}1080000 \\
(0,7 \%)\end{array}$ & -90 tys. & 33,9 & 2,17 & 507 & $\begin{array}{c}85104000 \\
(56,3 \%)\end{array}$ \\
\hline
\end{tabular}

Źródło: https://www.populationof.net/pl/philippines/ [dostęp: 17.01.2021]. Dane dotyczą końca podanych lat.

Wysuwając prognozy bardzo długoterminowe przewiduje się, że w 2100 r. dzietność na kobietę na poziomie 1,83. Ludność Filipin w owym roku ma wynieść $168 \mathrm{mln}$, a nawet mniej. Skończy się zatem zastępowalność pokoleń i rozpocznie (może nawet już wcześniej) spadek liczby ludności tego wówczas już bardzo gęsto zaludnionego kraju (560 osób na $\mathrm{km}^{2}$ ).

Co do bilansu migracyjnego, to trudno tu o rzetelne prognozy. Zależy to bowiem od polityk wizowych różnych państw. Chętnych są miliony, ale podczas gdy w latach 2010-2019 legalnie emigrowało nawet 130 tys. osób, ostatnio jest to około 100 tys., a przewidywany bilans dla lat następnych to ok. 90 tys. rocznie. W 1995 r. saldo migracji wyniosło ok. 153 tys. osób; pięć lat później było to już 219 tys., a w rekordowym 2005 r. aż ok. 300 tys. O zainteresowaniu emigracją niewątpliwie mogą świadczyć ciągłe kolejki do ambasady USA.

Tabela 3. Bieżąca populacja Filipin według wieku i płci dla początku roku 2021

\begin{tabular}{|l|l|l|l|}
\hline \multicolumn{1}{|c|}{ Kategoria wiekowa } & Mężczyźni & $\%$ & Kobiety \\
\hline $0-4$ & 6183574 & $\Leftarrow+9 \%$ & 5672856 \\
\hline $5-9$ & 5650726 & $\Leftarrow+2 \%$ & 5540805 \\
\hline $10-14$ & 5378759 & $\Leftarrow+6 \%$ & 5072673 \\
\hline $15-19$ & 5331656 & $\Leftarrow+10 \%$ & 4846446 \\
\hline $20-24$ & 5312639 & $\Leftarrow+4,5 \%$ & 5085700 \\
\hline $25-29$ & 4789922 & $\Leftarrow+1,9 \%$ & 4701333 \\
\hline
\end{tabular}




\begin{tabular}{|l|r|r|r|}
\hline $30-34$ & 3980451 & $\Leftarrow+1,4 \%$ & 3924964 \\
\hline $35-39$ & 3587797 & $\Leftarrow+0,7 \%$ & 3564163 \\
\hline $40-44$ & 3243577 & $\Leftarrow+1,1 \%$ & 3208257 \\
\hline $45-49$ & 2893008 & $+1 \% \Rightarrow$ & 2921126 \\
\hline $50-54$ & 2544499 & $+3,1 \% \Rightarrow$ & 2622481 \\
\hline $55-59$ & 2079938 & $+6,6 \% \Rightarrow$ & 2217190 \\
\hline $60-64$ & 1585110 & $+9,1 \% \Rightarrow$ & 1728964 \\
\hline $65-69$ & 1093439 & $+17,2 \% \Rightarrow$ & 1281870 \\
\hline $70-74$ & 654861 & $+32,2 \% \Rightarrow$ & 865444 \\
\hline $75-79$ & 347865 & $+47,8 \% \Rightarrow$ & 514031 \\
\hline $80-84$ & 213919 & $+60,3 \% \Rightarrow$ & 342911 \\
\hline $85-89$ & 85015 & $+73,3 \% \Rightarrow$ & 147355 \\
\hline $90-94$ & 19421 & $+116,4 \% \Rightarrow$ & 42029 \\
\hline $95-99$ & 2100 & $+47,8 \% \Rightarrow$ & 3104 \\
\hline $100+$ & 108 & $+10,2 \% \Rightarrow$ & 119 \\
\hline
\end{tabular}

Źródło: Organizacja Narodów Zjednoczonych, Departament Spraw Gospodarczych i Społecznych, Wydział Ludności (2015). Światowe Perspektywy Ludności: Wersja z 2015 r. Dane są szacunkami i prognozami na podstawie średniej płodności. Wykorzystany za zgodą Organizacji Narodów Zjednoczonych, http:// populacja.population.city/filipiny/\#1 [dostęp: 17.01.2021].

Na ruch naturalny ludności Filipin, oznaczający zmiany w populacji ludzkiej na skutek zdarzeń naturalnych, takich jak zawieranie związków małżeńskich, rozwodów, urodzeń i zgonów, ogromny wpływ ma Kościół katolicki, choć paradoksalnie postrzeganie społeczeństwa filipińskiego jako ultrakatolickiego jest w niemałym stopniu nieuzasadnione. Na przestrzeni lat nierzadko wielką popularnością cieszyli się różni politycy liberalni, kontrowersyjni, antyklerykalni, a nawet kryminalno-skandaliczni. Zdumienie może wywoływać popularność obecnego prezydenta Rodrigo Duterte, którego skandaliczne wypowiedzi nie mają sobie równych w świecie współczesnym, a Kościół katolicki podczas kampanii prezydenckiej określił go jako najgorszego kandydata na prezydenta. 
Na Filipinach od wielu lat ścierają się, rzutując na kwestie demograficzne, dwie zasadnicze koncepcje: konserwatywno-katolicka: im więcej dzieci, tym lepiej; liberalna: konieczność edukacji seksualnej, powstrzymanie przeludnienia, planowanie rodziny (z legalizacją aborcji włącznie), odpowiedzialność oraz zwracanie znacznie większej uwagi na kwestie ekologiczne. Powodzie w latach 80. ubiegłego wieku są czasem uznawane za cezurę, po której zaczęto na szeroką skalę uświadamiać sobie destrukcyjne skutki niszczenia lasów i wiązać tego typu działania z nadmiernym przyrostem populacji (konieczność pozyskiwania nowych terenów pod uprawy, rabunkowa gospodarka leśna).

W 2013 r. po trudnej debacie (16-letnie zmagania) została uchwalona przez parlament ustawa o zdrowiu reprodukcyjnym. Sąd Najwyższy nakazał jednak przełożenie jej wejścia w życie, aby wysłuchać argumentów dotyczących jej konstytucjonalności. Kontrowersje budziła zgodność ustawy z jednym z artykułów filipińskiej Konstytucji, który na równi stawia ochronę życia matki i nienarodzonego dziecka ${ }^{1}$. Paragraf 16 tej ustawy dotyczy obowiązkowej edukacji seksualnej oraz odnoszącej się do zdrowia reprodukcyjnego. Edukacji tej miałyby podlegać dzieci od piątej klasy. Z kolei paragraf 18 głosi, że małżeństwo może być zaaprobowane tylko w przypadku przyjęcia specjalnego certyfikatu wydawanego przez lokalny Urząd Planowania Rodziny. Przed uzyskaniem pozwolenia na ślub przyszli małżonkowie mają być poinstruowani na temat „odpowiedzialnego rodzicielstwa". Paragraf 20 z kolei dekre-

1 Ustawa ta wywołała liczne uliczne protesty, w tym tysięcy młodych, co zaskoczyło hierarchów kościelnych. Reakcje na nią były wielce emocjonalne, a lider jednej z największych charyzmatycznych grup chrześcijańskich Mike Velarde uznał nawet, że nowe prawo, jeżeli wejdzie w życie, doprowadzi do eliminacji Filipińczyków jako rasy i narodu, gdyż kraj wpadnie w moralny i ekonomiczny kryzys. 
tuje idealny rozmiar rodziny. Idealna rodzina to taka, która posiada dwoje dzieci. Za złamanie zasad tej ustawy są przewidziane kary wymienione w paragrafie 29. Może to być miesiąc do sześciu miesięcy więzienia lub grzywna w wysokości od 10 do 50 tysięcy peso. W niektórych przypadkach grzywna może być połączona z więzieniem². W lipcu 2014 r. Sąd Najwyższy, zatwierdzając ustawę legalizującą antykoncepcję, uznał jednak prawo lekarzy i placówek prywatnych do sprzeciwu sumienia. Najistotniejsze jest bowiem niedookreślenie, jakie środki są antykoncepcyjne, zaś jakie można zaliczyć do wczesnoporonnych.

Cechą charakterystyczną współczesnych Filipin jest ogromna dominacja (ludnościowa i nie tylko) rejonu stołecznego nad resztą kraju. Są oczywiście kraje, gdzie ta procentowa dominacja jest jeszcze bardziej znacząca, lecz sytuacja, gdy np. 42\% mieszkańców niewielkiego Urugwaju mieszka w stolicy, zdecydowanie różni się od tej na Filipinach, gdzie w Mega Manili (zespół siedemnastu miast Metro Manili oraz innych przyległych) wytwarzającej 90\% produkcji przemysłowej kraju żyje „tylko” 22\% Filipińczyków, skoro jest to populacja aż ok. 24-milionowa ${ }^{3}$. Mimo znaczącego postępu i istnienia w ramach rejonu stołecznego obszarów nowoczesności, a nawet luksusu, efektem wieloletniej eksplozji demograficznej jest ciągle chaotyczna, zaniedbana, niewydolna komunikacyjnie, niesterowna megametropolia straszliwych kontrastów, w której wegetują miliony Filipińczyków, a w związku z pandemią koronawirusa ich sytuacja już zdecydowanie się pogorszyła, zaś znaczące zmiany na lepsze należałoby odłożyć na bardziej od-

2 Aborcja na Filipinach, „The Guardian”, 19.07.2011, https://pl.qaz. wiki/wiki/Abortion_in_the_Philippines [dostęp: 17.01.2021].

3 Gęstość zaludnienia Manili (samej stolicy) to $43079 \mathrm{os} . / \mathrm{km}^{2}$. 
ległą przyszłość. Nasuwa się tu pytanie czy można sprawić, by stała się metropolią przyjazną człowiekowi nie za 100 lat, lecz już znacznie wcześniej. Oczywiście jest to pytanie, które można i należy kierować pod adresem całego szeregu współczesnych trzecioświatowych metropolii.

Polski pisarz, podróżnik i publicysta Olgierd Budrewicz w 1981 r. pisał: „W ciągu ostatnich dziesięciu lat przybyło w Manili kilka milionów ludzi (jest ich dzisiaj 7,5 mln) i wypiętrzyły się całe góry betonu. [...] Tondo, do którego dociera nie tyle oddech Miami, co Kalkuty. Trzęsawisko nędzy, rozległa dzielnica zasiedlona przez ludzi-szczury. Jeszcze jeden przykład skupiska istot pełzających w błocie i poniżeniu. [...] Tondo nie jest jedyne, takich obozowisk biedoty z dziećmi-szkieletami, trzydziestoletnimi zgrzybiałymi staruszkami, apatycznymi mężczyznami ma metropolis Manila tuziny"4. Wówczas populacja Filipin liczyła jedynie 46,5 mln. Była to populacja w większości niedożywiona. Stolica liczyła wówczas $7 \mathrm{mln}$ mieszkańców, a stopa bezrobocia wynosiła w wielkiej Manili jedynie 12\%. 35\% mieszkańców wielkiej Manili było pozbawionych wody i kanalizacji. Roczny przyrost ludności metropolii wynosił 4,4\%. Na 2000 r. prognozowano $15 \mathrm{mln}$. 30\% dzieci w kraju cierpiało na niedożywienie, a w najbiedniejszych prowincjach odsetek ten osiągał $80 \%^{5}$.

W pewnym stopniu alternatywą dla aglomeracji stołecznej jest położone ponad $200 \mathrm{~km}$ na północ miasto Baguio - niegdyś formalnie, dziś już nieformalnie letnia stolica kraju. Średnie temperatury o 8 stopni niższe niż w stolicy oraz inne walory klimatyczne sprawiają, że niejeden urzędnik czy nauczyciel jest skłonny wydać jedną czwartą swych miesięcznych docho-

4 O. Budrewicz, W cieniu bomby „D”, Warszawa 1982, s. 102.

5 Ibidem, s. 106. 
dów, by spędzić w tym mieście jeden weekend, odpoczywając od zgiełku, upału, smogu i innych niedogodności stołecznej metropolii. To sprawiło, że Baguio również wkroczyło w fazę chaotycznego rozwoju, zgiełku, hałasu, boomu budowlanego, a już wkrótce osiągnie 400 tys. mieszkańców. Na przykładzie tego miasta można obserwować charakterystyczną dla wielu filipińskich miast antropopresję (widoczną szczególnie spektakularnie na wzgórzach). Coraz więcej wzgórz - niegdyś pokrytych bujną roślinnością - przemienia się w osiedla z gęstą zabudową. Proces ten będzie niewątpliwie postępował, będąc żywym przykładem zwycięstwa człowieka nad przyrodą w nie najlepszym tego słowa znaczeniu.

Tabela 4. Ludność wybranych miast w latach 1990-2021

\begin{tabular}{|l|c|c|c|c|}
\hline \multicolumn{1}{|c|}{ Miasto } & 1990 & 2000 & 2010 & 2021 (prognoza) \\
\hline Manila & 1601230 & 1581080 & 1652170 & 1946872 \\
\hline Davao City & 849950 & 1147120 & 1449300 & 1884412 \\
\hline Quezon City & 1669780 & 2173830 & 2761720 & 3159988 \\
\hline Zamboanga & 442350 & 601790 & 807130 & 932313 \\
\hline Cebu City & 610420 & 718820 & 866170 & 995214 \\
\hline Lapu-Lapu & 146190 & 217020 & 350470 & 489935 \\
\hline Puerto Princesa & 92150 & 161910 & 222670 & 300346 \\
\hline Taguig & 266640 & 467380 & 644470 & 1051004 \\
\hline Antipolo & 205096 & 470870 & 677740 & 913891 \\
\hline Pasig & 397680 & 505060 & 669770 & 872468 \\
\hline Iloilo City & 309510 & 366390 & 424620 & 477744 \\
\hline General Santos & 250390 & 411820 & 538090 & 669924 \\
\hline Bacolod & 364180 & 429080 & 511820 & 628444 \\
\hline Baguio & 183140 & 252390 & 318680 & 380361 \\
\hline Legaspi & 121116 & 157010 & 182201 & 215483 \\
\hline
\end{tabular}

Źródło: opracowanie własne na podstawie: http://populacja.population.city/filipiny/\#cities [dostęp: 31.01.2021]; https://pl.qaz. wiki/wiki/Antipolo [dostęp: 31.01.2021]; https://www.google. $\mathrm{com} / \mathrm{search}$ ?ei=a0AXYJOeMcX0kgXcmqO4DA\&q=Legaspi [dostęp: 31.01.2021]. 
Mimo dużej gęstości zaludnienia, nawet na wyspie Luzon (prawie 600 osób na $\mathrm{km}^{2}$ ) są ogromne obszary zielone, górskie, gdzie ludzkie osady występują rzadko. Udając się ze stołecznej metropolii na północ można zadawać sobie pytanie, gdzie to filipińskie przeludnienie. Jednakże podróżując na południe - w kierunku Legaspi - doświadcza się subiektywnego odczucia przeludnienia, gdyż na 600-kilometrowej trasie dominują wsie-ulicówki, zatem ciągnie się teren zabudowany, rzadko przerywany obszarami zielonymi.

Należy zauważyć, że ciągle część nawet większych filipińskich wysp odznacza się rzadkim zaludnieniem. Dla wyspy Samar jest to ok. 100 osób na km², a dla modnej turystycznie i wysoko notowanej w światowych rankingach wyspy Palawan - jedynie ok. 70 osób na $\mathrm{km}^{2}$. Z kolei wyspa Cebu charakteryzuje się już zdecydowanie dużą gęstością zaludnienia - ponad 700 osób na $\mathrm{km}^{2}$.

Wielkość populacji Filipin sprawia, że prowadzona przez prezydenta Duterte wojna z narkobiznesem (giną handlarze narkotyków, narkomani oraz osoby postronne), nawet jeżeli pochłonęła już być może kilkadziesiąt tysięcy ofiar, nie wpływa istotnie na sytuację demograficzną kraju. Niewielkie znaczenie ma również osiedlanie się na Filipinach rezydentów zazwyczaj emerytów z zamożnych krajów oraz rosnąca liczba samobójstw wywołanych kryzysem. Znacznie większy, a nawet ogromny wpływ na sytuację demograficzną ma natomiast aborcyjne podziemie. Aborcja została uznana za przestępstwo przez Kodeks karny z 1870 r. pod hiszpańskimi rządami kolonialnymi, a przepisy karne zostały włączone do zrewidowanego Kodeksu karnego uchwalonego w 1930 r., gdy Filipiny były pod panowaniem amerykańskim. W 2008 r. szacowano, że karny zakaz aborcji doprowadził do śmierci jedynie w tym jednym roku co najmniej 1000 kobiet i do powikłań u 90 tys. 
kolejnych. Lekarzom i położnym, którzy dokonują aborcji na Filipinach za zgodą kobiety w ciąży, grozi nawet sześć lat więzienia według znowelizowanego Kodeksu karnego. Z kolei kobietom, które z jakiegokolwiek powodu poddają się aborcji, grozi kara pozbawienia wolności od dwóch do sześciu lat ${ }^{6}$.

Mimo nielegalności aborcji kupno środków aborcyjnych nie stanowi problemu, a - paradoksalnie - miejscem, gdzie są powszechnie dostępne jest teren znanego kościoła Quiapo w Manili.

Od lat 70. XX w. istnieje filipiński program planowania rodziny, lecz poniósł klęskę podczas administracji pani prezydent Corazon Aquino (1986-1992), kiedy wsparcie dla tego programu zostało osłabione w wyniku silnego wpływu Kościoła katolickiego. Ponadto, w wyniku decentralizacji świadczeń zdrowotnych na rzecz jednostek samorządu terytorialnego w 1993 r., samorządy lokalne przejęły główną odpowiedzialność za świadczenie usług planowania rodziny.

Właśnie ze względu na ogromną siłę Kościoła katolickiego - rząd nie ma jasnej polityki dotyczącej aborcji. Politycy filipińscy nigdy nie wspominają o tym w swoich publicznych wystąpieniach, z wyjątkiem potępienia tego zjawiska. W międzyczasie pojawiają się doniesienia o kobietach umierających lub hospitalizowanych z powodu aborcji oraz o płodach znalezionych na wysypiskach śmieci lub wręcz w kościołach katolickich i wokół nich.

Oficjalne szacunki informują o rocznej liczbie aborcji w przedziale od 400 tys. do pół miliona. Według szacunków WHO liczba ta wynosi prawie 800 tys. Według przedstawiciela WHO Jeana-Marca Olivé 70\% niechcianych ciąż

6 Fakty dotyczace aborcji na Filipinach: kryminalizacja i ogólny zakaz aborcji (PDF). Centrum Praw Reprodukcyjnych. 
na Filipinach kończy się aborcją. Z kolei według organizacji antyaborcyjnej Pro-Life Philippines jedna z czterech ciąż na Filipinach kończy się aborcją, a to już ogromnie rzutuje na kwestię demograficzną kraju. Według WHO problem komplikuje fakt, że 36\% filipińskich kobiet zachodzi w ciążę przed ślubem, a 45\% wszystkich ciąż jest niechcianych lub w niewłaściwym czasie. „Wygląda na to, że rodziny chciałyby mieć przynajmniej jedno dziecko mniej niż to, co mają" - stwierdził Jean-Marc Olivé7.

Filipiny, z ciągle wysokim tempem wzrostu populacji i niskim wskaźnikiem stosowania środków antykoncepcyjnych (szacunkowo 35\%), również odnotowują rosnącą liczbę ciąż wśród nastolatek. Według Departamentu Zdrowia, aż 17\% wszystkich nielegalnych aborcji jest wykonywanych $\mathrm{u}$ nastoletnich lub młodych matek.

Według badania przeprowadzonego przez University of the Philippines, około 4 na 5 aborcji na Filipinach ma miejsce z przyczyn ekonomicznych. Jocelyn Pacete, rzeczniczka prasowa Likhaan, organizacji zajmującej się zdrowiem kobiet z siedzibą w Manili, mówi że w wielu przypadkach „matki nie stać na kolejne dziecko, więc ostatecznie wybiera pięcioro żyjących dzieci zamiast płodu w jej łonie" ${ }^{8}$. Narodowy Rejon Stołeczny ma najwyższy odsetek ciąż kończących się aborcją (jedna na trzy), w porównaniu z około jedną piątą w pozostałej części wyspy Luzon i około jedną na osiem w Visayas i na Mindanao. Na Filipinach wyraźnie widać duże różnice w rodzajach stosowanych metod aborcyjnych, bezpieczeństwie zabiegu i prawdopodobieństwie powikłań, w zależności od

7 C.H. Conde, Filipiński kryzys aborcyjny, „The New York Times”, https://www.nytimes.com/2005/05/16/world/asia/philippines-abortioncrisis.html [dostęp: 16.05.2005].

8 Ibidem. 
poziomu dochodów kobiety, klasy społecznej i miejsca zamieszkania.

Niewątpliwie interesującą informacją na temat zachowań seksualnych młodych Filipinek są dane pochodzące z reprezentatywnego badania z 1994 r. Wówczas jedynie około 9\% samotnych kobiet w wieku 15-24 lat deklarowało, że kiedykolwiek odbyło stosunek płciowy. Dziś wyniki takich badań mogłyby być zdecydowanie odmienne.

Filipińskie prawo zakazuje bezwzględnie przerywania ciąży, aczkolwiek aborcja dokonana w celu ratowania życia matki jest uważana za legalną w oparciu o zasadę stanu wyższej konieczności. Zakaz aborcji (de facto nawet w przypadku gwałtu czy kazirodztwa) jest potwierdzony przez odpowiedni zapis w art. 12 Konstytucji kraju z 1987 r. „Państwo uznaje świętość życia rodzinnego oraz chroni i wzmacnia rodzinę jako podstawową niezależną instytucję społeczną. Chroni ona w równym stopniu życie matki i życie nienarodzonych od poczęcia”. Art. 256, 258 i 259 znowelizowanego Kodeksu karnego Filipin nakazują karę pozbawienia wolności kobietom poddającym się aborcji, a także każdej osobie, która pomaga w procedurze. Art. 258 nakłada ponadto na kobietę lub jej rodziców wyższą karę pozbawienia wolności, jeżeli aborcja została podjęta „w celu ukrycia hańby [kobiety]”. Kościół katolicki sprzeciwiał się propozycjom liberalizacji filipińskich przepisów dotyczących aborcji. Jednak konstytucyjność ograniczeń aborcyjnych nie została jeszcze zakwestionowana przed filipińskim Sądem Najwyższym. Przepis Konstytucji, że „[Państwo] chroni w równym stopniu życie matki i życie nienarodzonego dziecka od poczęcia” został opracowany przez Komisję Konstytucyjną, która opracowała projekt karty z zamiarem zapewnienia konstytucyjnej ochrony zakazu aborcji, chociaż 
uchwalenie bardziej radykalnego przepisu sankcjonującego zakaz nie powiodło się. Przepis ten jest wymieniony wśród kilku polityk państwowych, które są powszechnie uważane w prawie za niewykonalne w przypadku braku przepisów wykonawczych. Analiza przeprowadzona przez Wydział Ludności Departamentu Spraw Gospodarczych i Społecznych ONZ wykazała, że chociaż w zmienionym Kodeksie karnym nie wymieniono konkretnych wyjątków od ogólnego zakazu aborcji, zgodnie z ogólnymi zasadami prawa karnego, określonymi w art. 11 (4) Kodeksu można legalnie dokonać aborcji w celu ratowania życia kobiety ciężarnej9.

Niektórzy lekarze potajemnie przeprowadzają aborcje w klinikach, pobierając za tę „usługę” opłatę od 37 do 93 USD. Cena jest zbyt wysoka dla wielu kobiet, więc zamiast tego kupują środki poronne na czarnym rynku lub szukają rozwiązań u praktykujących medycynę ludową. W 1994 r. 12\% wszystkich zgonów matek było spowodowanych aborcją. Pomimo surowości prawa aborcja na Filipinach wydaje się być szeroko praktykowana. Badania z połowy lat 90. wskazują, że kobiety ze wszystkich klas społecznych i środowisk dokonywały aborcji w różnych okolicznościach - począwszy od bezpiecznych zabiegów medycznych wykonywanych dla zamożniejszych kobiet przez wyszkolony personel po zabiegi w skrajnie niebezpiecznych warunkach - dla biednych kobiet. Trudny dziś do oszacowania kryzys wywołany pandemią i rządowymi reakcjami na nią może zdecydowanie nasilić zasięg aborcji wykonywanych w niebezpiecznych warunkach, tym bardziej że cena nowoczesnych środków antykoncepcyjnych dla znacznie większej liczby kobiet okaże się ceną zaporową.

9 Aborcja na Filipinach, „The Guardian”, 19.07.2011, https://pl.qaz. wiki/wiki/Abortion_in_the_Philippines [dostęp: 17.01.2021]. 
Niemal pół miliona wywołanych aborcji, które mają miejsce każdego roku na Filipinach, nie może być rozumianych w oderwaniu od ogólnie restrykcyjnego klimatu społecznego i politycznego, otaczającego świadczenie nowoczesnych usług antykoncepcyjnych. Ponadto decentralizacja świadczenia usług zdrowotnych najprawdopodobniej przyczynia się do trudności kobiet filipińskich w uzyskaniu informacji, usług i materiałów antykoncepcyjnych. Co więcej, negatywne nastawienie mężów do planowania rodziny oraz błędne wyobrażenie kobiet o skutkach ubocznych tych metod uniemożliwia wielu kobietom stosowanie antykoncepcji ${ }^{10}$.

Kościół katolicki krytycznie odnosił się do administracji prezydenta Fidela Ramosa (1992-1998), która promowała stosowanie sztucznych lub nowoczesnych metod kontroli urodzeń i prowadził kampanię przeciwko politykom popierającym nowoczesne planowanie rodziny. Z kolei pod przewodnictwem pani prezydent Glorii Macapagal-Arroyo (2001-2010) narodowy program dotyczący populacji i zdrowia reprodukcyjnego popierał tradycyjne metody planowania rodziny, ponieważ „promują one wartości rodzinne” ${ }^{11}$.

Obecnie Kościół katolicki kwestionuje projekt ustawy o rozszerzeniu dostępności określonych środków antykoncepcyjnych. Jednakże jest już od lat wdrażany przez Departament Zdrowia Narodowy Program Planowania Rodziny, „mający na celu pomóc rodzinom osiągnąć pożądaną wielkość rodziny poprzez powszechny dostęp do wysokiej jakości informacji i usług w zakresie planowania rodziny. Obej-

10 https://pl.qaz.wiki/wiki/Abortion_in_the_Philippines [dostęp: 18.01.2021].

11 F. Juarez, J. Cabigon, S. Singh, R. Hussain, Częstość występowania aborcji indukowanej na Filipinach: obecny poziom i najnowsze trendy, Istytut Guttmachera, wrzesień 2005, s. 140-149. 
muje to dostarczanie produktów do planowania rodziny, które są bezpieczne z medycznego punktu widzenia, legalne, niepowodujące poronienia, skuteczne i akceptowalne kulturowo. Usługi te są świadczone w szpitalach i innych placówkach służby zdrowia. To właśnie ten Narodowy Program Planowania Rodziny spowolnił wzrost populacji Filipin" ${ }^{12}$.

Z pewnością pocieszający jest trend, który doprowadził do tego, iż jedynie 11,9\% dzieci rodzą kobiety w wieku 15-19 lat i aż 35,6\% dzieci to dzieci, które rodzą kobiety po 30. roku życia. W wielu państwach Trzeciego Świata sytuacja pod tym względem przedstawia się zdecydowanie inaczej.

Każdy demograf czy człowiek zabierający głos w dyskusji na tematy demograficzne posiada określone poglądy, które nakłada na interpretację faktów, kreśląc postulaty, pragnienia, ocenę rzeczywistości, więc bardzo trudno tu o obiektywizm. Inaczej podchodzi do tej kwestii analityk zorientowany bardziej ekologicznie, a inaczej konserwatywny hurapatriota, który pragnie, by jego kraj był ludnościową potęgą, za którą powinna podążać odpowiednia siła polityczna i gospodarcza. W wielu przypadkach można nawet mówić o pragnieniu wygrywania wyścigów demograficznych, głównie z sąsiadami. Czy Filipiny są krajem, w którym potencjał demograficzny ma przełożenie na potęgę polityczno-gospodarczo-militarną $\mathrm{w}$ regionie? W pewnym stopniu zapewne tak. Oczywiście nie chodzi tu o skuteczną rywalizację z Chinami czy Indiami, ale już z Malezją, Tajlandią, Wietnamem czy Birmą z pewnością tak. Nie mówiąc nawet o państwach zdecydowanie mniejszych, przede wszystkim w ramach ASEAN-u.

12 Close watch urged on population dev'ts, "Manila Bulletin”, 18.02.2020, s. 4 . 
Na trendy demograficzne wpływa cały szereg czynników, które często są trudne do przewidzenia, jak choćby obecna pandemia. To sprawia, że przyszłość jest także w tym wymiarze pełna niewiadomych. Współczesne Filipiny (jeszcze przed pandemią) to kraj ogromnego ukrytego bezrobocia. Nie było ono ukrywane propagandowo (ideologicznie), jak w realnym socjalizmie, lecz - nazwijmy to - technicznie. Reakcja na pandemię sprawiła, że pojawiły się nawet szacunki, według których w lipcu 2020 r. bezrobocie doszło do rekordowego poziomu 45,5\%, a dziś może wynosić nawet $50 \%$ siły roboczej. Wystarczy odnotować, że z 55 tys. jeepneyów w Manili jeździ tylko kilkaset. Ludzie umierają z niedożywienia i różnych innych chorób podczas kwarantanny. Mimo wielkich pieniędzy pompowanych w gospodarkę, PKB Filipin skurczył się w trzecim kwartale 2020 r. o 11,5\%, a przecież był to kraj rozwijający się w tempie nawet $7 \%$ rocznie. Kryzys sprzed trzynastu lat uderzył najdotkliwiej w Indonezję; obecny w Filipiny - spośród jedenastu państw regionu, a to dopiero początek.

W zestawieniach statystycznych dotyczących Filipin mieliśmy przez dziesiątki lat miliony podmiotów gospodarczych, miliony samozatrudnionych. W praktyce trudno zachwycać się sklepem czy warsztatem usługowym, w którym czasem przez cały dzień żaden klient nie zostawił choćby kilku pesos. Bieda-podmiotów gospodarczych jest tak duża, gdyż miliony Filipińczyków nie mają innego pomysłu na biznes czy po prostu na życie. Pandemia sprawiła, że sytuacja uległa drastycznemu pogorszeniu, wywołując efekt krzyżujących się kryzysów.

Oczywiście nawet głęboka recesja nie oznacza dosłownego cofnięcia gospodarki, np. w sferze technologicznej, a zbiednienie nie musi oznaczać powrotu do wcześniej- 
szych postaw, wzorców i zachowań prokreacyjnych. Brak oszczędności u milionów rodzin, znacznie niższe dochody i zarazem chęć obrony określonego standardu życia prawdopodobnie sprawią, że nawet głęboki kryzys nie wpłynie znacząco na przewidywane przed kryzysem tendencje demograficzne. Miliony Filipińczyków przekonały się już, że rodzina z dwojgiem dzieci żyje z reguły na znacznie wyższym poziomie konsumpcyjnym niż rodzina wielodzietna, a drastyczne ograniczenie konsumpcji to ogromny dyskomfort. Dane z Indonezji z lata 2020 r. wskazują jednak na lekki wzrost przyrostu naturalnego, wiązany nie tyle z pauperyzacją, ile ze spędzaniem w domu większej ilości czasu niż poprzednio.

Współczesne Filipiny to także kraj refleksji demograficznych, które mogą zaskakiwać. Dzieci rodzi się za mało! - nie brakuje takich, którzy tak twierdzą - i nie są to tylko wybrani hierarchowie Kościoła katolickiego. Kategoria wiekowa seniorów - 60 lat i więcej rośnie bowiem w szybszym tempie niż pozostałe kategorie wiekowe i stanowi już 8,8\% całej populacji. Dla porównania kategoria wiekowa od 0 do 14 lat spadła z 34\% w 2010 r. do 30,14\% w 2020 r. ${ }^{13}$ To może wywołać perturbacje na rynku pracy, gdyż osoby w wieku poprodukcyjnym (formalnie) będą stanowiły coraz większe obciążenie dla pracujących. Zamiast miękkiego już można zaobserwować twarde spowolnienie przyrostu populacji. Inni dodają, że w zasadzie społeczeństwo powinno być wiecznie młode, a starzenie się każdego społeczeństwa to zło (dziś średnia wieku to „aż” 28,4 lata, a było 21,9$)^{14}$.

13 Ibidem.

14 Rządzący rzadko deklarują optymalną liczbę ludności krajów, w których sprawują władzę. Deng Xiaoping, twierdzący w końcu lat 70., że dla Chin 700 mln mieszkańców to wielkość optymalna, był tu wyjąt- 
Wśród wielu demografów funkcjonuje dyrektywa głosząca, że nigdzie (w żadnym kraju) liczba ludności nie powinna spaść poniżej poziomu już raz osiągniętego, a ponieważ idealna stabilizacja jest niemożliwa, należy postulować bezterminowy wzrost. Do tego można jeszcze dodać refleksję dwojga ekonomistów (Ester Boserup i Julian Simon), niektórych hierarchów Kościoła na Filipinach oraz określonych polityków - głoszących, że znaczący przyrost naturalny to szansa, a nie zagrożenie. Więcej ludzi to więcej umysłów (mądrość) i rąk do pracy (zmienianie kraju na lepsze). Będąc nawet w wieku przedprodukcyjnym dzieci mogą stymulować rozwój, gdyż jako osoby na utrzymaniu rodziców motywują ich do wydajniejszej pracy. Aspekt ekologiczny jest tu całkowicie pominięty. Tymczasem współczesne Filipiny to kraj zniszczonych lasów pierwotnych, przełowionych łowisk, brudnych plaż. Ogromny wzrost populacji w niszczeniu przyrody odegrał tu rolę decydującą. Odpowiedzialność człowieka za siebie, za rodzinę, za kraj, a tym bardziej za świat to postawa, która pojawia się dopiero wraz ze wzrostem zamożności. Trudno jednak osiągnąć zamożność w sytuacji, gdy prokreacją bardziej rządzą żywiołowe instynkty niż działania racjonalne.

kiem. Prezydent Iranu Hasan Rouhani z kolei opowiedział się w 2020 r. za podwojeniem liczby ludności. Nietrudno się domyślić, że chodzi tu głównie o wzmocnienie roli islamskiego szyizmu w świecie. Niekiedy można było usłyszeć z ust polityków niższego szczebla w Polsce, że „przecież chcemy być stumilionowym narodem w środku Europy”. Zasadniczo dominuje wśród polityków oraz publicystów czy duchownych w różnych krajach świata stanowisko, że liczba ludności nie powinna spadać, szczególnie w dłuższej perspektywie czasowej. Taka opinia stanowi swoisty polityczny dogmat w zakresie demografii, a nawet niewielki spadek liczby ludności nazywany jest wymieraniem narodu. 


\section{Bibliografia}

Aborcja na Filipinach. „The Guardian”, 19.07.2011, https://

pl.qaz.wiki/wiki/Abortion_in_the_Philippines.

Budrewicz O., W сіеniu bomby „D”, Warszawa 1982.

Close watch urged on population dev'ts, „Manila Bulletin”, 18.02.2020.

Fakty dotyczace aborcji na Filipinach: kryminalizacja i ogól$n y$ zakaz aborcji (PDF). Centrum Praw Reprodukcyjnych. Forsaken Lives: Szkodliwy wptyw filipińskiego zakazu aborcji (PDF). Centrum Praw Reprodukcyjnych.

Juarez F., Cabigon J., Singh S., Hussain R., Czestość występowania aborcji indukowanej na Filipinach: obecny poziom $i$ najnowsze trendy, Instytut Guttmachera, wrzesień 2005, t. 31, https://www.guttmacher.org/journals/ ipsrh/2005/09/incidence-induced-abortion-philippinescurrent-level-and-recent-trends.

Owsiany T., Pod ciemnq skórą Filipin, Warszawa 2017.

Rights Group potępia nielegalność aborcji na Filipinach, „The New York Times”, 2.08.2010.

Singh S., Juarez F., Cabigon J., Ball H., Hussain R., Nadeau J., Niezamierzona ciaża i aborcja wywotana na Filipinach: przyczyny i konsekwencje, Instytut Guttmachera (PDF).

\section{Netografia}

Conde C.H., Filipiński kryzys aborcyjny, „The New York Times", https://www.nytimes.com/2005/05/16/world/asia/ philippines-abortion-crisis.html.

Edukacja na Filipinach, https://pl.qaz.wiki/wiki/Education_ in_the_Philippines.

Na-Filipinach-epidemia-poglebia-glod-i-ubostwo, https:// kosciol.wiara.pl/doc/6263759.

Troje-dzieci-wystarczy, https://kosciol.wiara.pl/doc/3266282. 
https://news.abs-cbn.com/nation/metro-manila/09/15/10/ dead-babies-discovered-near churches.

https://kosciol.wiara.pl/doc/6263759.Na-Filipinach-epidemia-poglebia-glod-i-ubostwo.

https://www.nytimes.com/2005/05/16/world/asia/philippines-abortion-crisis.html.

https://pl.qaz.wiki/wiki/Abortion_in_the_Philippines.

https://www.populationof.net/pl/philippines/.

Organizacja Narodów Zjednoczonych, Departament Spraw Gospodarczych i Społecznych, Wydział Ludności (2015). Światowe Perspektywy Ludności: Wersja z 2015 r. Dane są szacunkami i prognozami na podstawie średniej płodności. Wykorzystany za zgodą Organizacji Narodów Zjednoczonych, http://populacja.population.city/filipiny/\#1.

https://wiadomosci.wp.pl/kosciol-przeciw-ustawie-o-planowaniu-rodziny-6032726731100801a.

https://reproductiverights.org/sites/crr.civicactions.net/files/documents/pub_fac_philippines_1\%2010.pdf. http://populacja.population.city/filipiny/\#cities. https://pl.qaz.wiki/wiki/Antipolo [dostęp: 31.01.2021]. https://www.google.com/search?ei=a0AXYJOeMcX0kgXcmqO4DA\&q=Legaspi.

Wspótpraca mimo prób kompromitacji, https://kosciol.wiara.pl/doc/899621.Wspolpraca-mimo-prob-kompromitacji.

\section{Abstrakt}

Filipiny, kraj wielkości Włoch, z populacją około 5 milionów 150 lat temu, są teraz zdecydowanie potęgą demograficzną. W przyszłości pod względem liczby ludności najprawdopodobniej wyprzedzą naj- 
pierw Japonię, a potem być może Rosję. Naturalny wzrost na przestrzeni lat zdecydowanie wyhamował, ale nadal jest to ogromne wyzwanie dla polityków filipińskich, osób odpowiedzialnych za politykę społeczną, ochronę zdrowia, edukację i ekologię. Ogromnym problemem związanym ze stale rosnącą populacją jest ubóstwo milionów obywateli, w tym dzieci. Mimo ogromnego postępu, jaki dokonał się w ostatnich dziesięcioleciach, oazy nowoczesności wciąż stanowią wyjątek, a tym bardziej kontrastują z dzielnicami skrajnej biedy. Zarośnięta metropolia stolicy łączy w sobie zarówno pozytywne, jak i negatywne cechy w filipińskiej rzeczywistości, będąc ogromnym wyzwaniem na kolejne dziesięciolecia. Dziś Filipiny szybko przestały być krajem 6-7\% wzrostu PKB, stając się krajem gwałtownie rosnącego bezrobocia - oczywiście z powodu pandemii. To również sprawia, że przyszłość demograficzna jest znacznie trudniejsza do przewidzenia. Na demografię Filipin od lat wpływa pozycja Kościoła katolickiego, który w dużej mierze kształtuje system prawny kraju, głównie w zakresie planowania rodziny. Niewątpliwie wstydliwym tematem jest nielegalna aborcja, która ma ogromny zasięg. Innymi czynnikami kształtującymi populację Filipin jest spadająca dzietność, powolne starzenie się społeczeństwa oraz ograniczony dostęp do nowoczesnej antykoncepcji - z przyczyn materialnych, związanych z poziomem wykształcenia i miejscem zamieszkania. Religia i tradycje niereligijne mają również istotny wpływ na postawy prokreacyjne. Pod pewnymi względami Filipiny są podobne do krajów Ameryki Łacińskiej. Można to sobie uświadomić, gdy dowiemy się, że mężowie często nie pozwalają swoim żonom na stosowanie środków antykoncepcyjnych, a tym bardziej są skłonni pozwolić kobiecie na nielegalne przerwanie ciąży. Filipiny to kraj, w którym przyroda od dawna przegrywa z rosnącą populacją. Wielkie powodzie w latach 80. XX wieku postrzegane są przez niektórych jako przełom w myśleniu. Wtedy wreszcie zauważono, że niszczenie lasów prowadzi do powodzi, a przyczyną takiego rabunku jest stale rosnąca populacja, która potrzebuje nawet nowych gruntów pod uprawę. Na szczęście populacja wysp filipińskich jest bardzo nierównomierna, więc nadal istnieje wiele obszarów o prawie nienaruszonej przyrodzie; nadal istnieją wyspy (niekoniecznie bardzo małe) o niskiej gęstości zaludnienia, a prognozuje się, że szczyt populacji osiągnie około 2100 r., po czym zacznie spadać. 
Słowa kluczowe: Filipiny, populacja, perspektywy demograficzne, aborcja, Manila

\begin{abstract}
The Philippines, a country the size of Italy, with a population of around 5 million 150 years ago, is now definitely a demographic power. In the future, in terms of population, it will most likely overtake Japan first and then perhaps Russia. Natural increase over the years has decisively slowed down, but it is still a huge challenge for Filipino politicians, people responsible for social policy, health protection, education and ecology. The huge problem associated with an evergrowing population is the poverty of millions of citizens, including children. Despite the enormous progress made in recent decades, the oases of modernity are still exceptions, so they contrast all the more with districts of extreme poverty. The overgrown metropolis of the capital brings together both the positive and the negative in the Filipino reality, being a huge challenge for the next decades. Today, the Philippines has quickly stopped being a country of $6-7 \%$ GDP growth, becoming a country of rapidly growing unemployment - of course due to the pandemic. This also makes the demographic future much more difficult to predict. The demographics of the Philippines has been influenced for years by the position of the Catholic Church, which largely shapes the country's legal system, mainly with regard to family planning. Undoubtedly, an embarrassing topic is illegal abortion which has a huge scope. Other factors shaping the population of the Philippines are the declining fertility rate, slow aging of the population, and limited access to modern contraception - for material reasons, related to the level of education and place of residence. Religion and non-religious traditions also have a significant impact on procreative attitudes. In some ways, the Philippines is similar to Latin American countries. This can be realized when we learn that husbands often refuse to allow their wives to use contraceptives, even more inclined to let the woman terminate the pregnancy illegally. The Philippines is a country where nature has long been losing out to a growing population. The great floods of the $1980 \mathrm{~s}$ are seen by some as a breakthrough in thinking. At that time, it was finally noticed that the destruction of forests leads to floods, and the cause of such robbery is the constantly growing population, which
\end{abstract}


needs even new land for cultivation. Fortunately, the population of the Philippine islands is very uneven, so there are still many areas of almost untouched nature; there are still islands (not necessarily very small) with a low population density, and the population is forecast to peak around 2100 , after which it will start to decline.

Keywords: Philippines, population, demographic prospects, abortion, Manila 


\author{
Vindensius Adi Gunawan \\ Catholic University of Kupang \\ Janusz Mariański \\ Katolicki Uniwersytet Lubelski \\ ORCID ID: https: / / orcid.org/0000-0002-0620-8000
}

\title{
Modernizacja społeczna a religie (przypadek Indonezji)
}

Modernizacja społeczna prowadząca do ponowoczesności czy zmodernizowanej nowoczesności wydaje się charakteryzować większość wysoko rozwiniętych społeczeństw współczesnych, a nawet wykazuje pewne znamiona zjawiska ogólnoświatowego. Wiąże się ona często z pluralizacją, indywidualizacją i sekularyzacją jako ważnymi siłami tego procesu oraz detradycjonalizacją jako jej skutkiem. W fazie ponowoczesnej modernizacja niesie ze sobą nie tylko zagrożenia dla religii, ale i pewne nowe szanse związane z odradzaniem się religijności w jej zróżnicowanych kształtach. Transcendencja nie jest skazana na ostateczną zagładę. Ponowoczesne losy religii - jak to określa Zygmunt Bauman - są o wiele bardziej skomplikowane, niż domyślali się jej nowocześni krytycy ${ }^{1}$. Modernizacja społeczna jest - być może - w jakimś stopniu stałym stanem ludzkiego sposobu życia, nawet jeżeli jej przyszłość jest wciąż wieloznaczna, niejasna i pełna niespodzianek.

1 A. Zeidler-Janiszewska (red.), O szansach i putapkach ponowoczesnego świata. Materiały z seminarium Profesora Zygmunta Baumana w Instytucie Kultury (jesień 1995-wiosna 1996), Warszawa 1997, s. 130-170 . 
Teorie modernizacji społecznej zakładają na ogół zmiany kulturowe dotyczące przekonań ludzi, m.in. od wartości przetrwania do wartości swobodnej ekspresji i od wartości tradycyjnych do wartości świecko-racjonalnych. Proces sekularyzacji, który towarzyszy modernizacji społecznej, osłabia w społeczeństwach postindustralnych siłę wartości religijnych. Według teorii sekularyzacji „modernizacja prowadzi do osłabienia wiary religijnej, na co wskazuje mniejsza liczba wiernych w kościele, mniejsze posłuszeństwo wobec obrządku, osłabienie wiary w autorytety religijne, coraz wyraźniejsze oddzielenie Kościoła od państwa oraz fakt, że symbole religijne, doktryny i instytucje tracą swój prestiż i wpływy. Teorie modernizacji sugerują, że coraz wyższy poziom edukacji i szerząca się umiejętność czytania i pisania, coraz bogatsze źródła informacji umocniły racjonalną wiarę w wiedzę naukową, autorytet ekspertów i technologiczny knowhow, a księża, pastorzy, rabini i mułłowie są tylko jednym z autorytetów, niekoniecznie najważniejszym, który w dodatku konkuruje z wiedzą ekspertów i profesjonalistów, takich jak psychologowie, fizycy czy lekarze"2.

Postępy sekularyzacyjne są najbardziej widoczne w spadku regularnej frekwencji na mszach i w nabożeństwach kościelnych. Niepodważalny aksjomat zapowiadający zmierzch religii i Kościołów wyrażał się w formule: im bardziej jest nowoczesne społeczeństwo, tym staje się ono bardziej zsekularyzowane. Sekularyzacja społeczeństwa i kultury, ich instytucji, ale także osób ludzkich, wydawała się procesem nieodwracalnym („więcej nowoczesności oznacza mniej religii").

2 R. Inglehart, P. Norris, Wzbierająca fala. Równouprawnienie ptci a zmiana kulturowa na świecie, tłum. B. Hellmann, Warszawa 2009, s. 64-65. 
Religia w warunkach nowoczesności traci - według tej teorii - swoją zdolność legitymizowania oraz konstruowania porządku społecznego i moralnego, ustawicznie zmniejsza się jej znaczenie społeczne, może się utrzymać jedynie w szczelinach i niszach głównego nurtu życia społecznego. Sekularyzacja nie jest ubocznym „produktem” pewnych form życia społecznego, lecz jego cechą konstytutywną. Sacrum zniknie z życia codziennego ludzi, co najwyżej może utrzymać się w sferze prywatnej. Upowszechniający się sekularyzm, znajdujący swój wyraz w doktrynach filozoficznych, konstytucjach i strukturach państwowych, upodabnia się pod wieloma względami do religii zinstytucjonalizowanej ${ }^{3}$.

W swoich skrajnych formach sekularyzm odmawia religii prawa i zdolności kształtowania spraw publicznych i losu ludzi w przyszłości. Filozofowie i socjologowie Oświecenia atakowali tradycję, autorytet religijny i zastane poglądy. Twierdzili, że postęp ludzkości może dokonać się jedynie poprzez racjonalne myślenie i wykorzystanie metod naukowych oraz dążenie do wolności i równości ${ }^{4}$. Klasycy socjologii przypisywali ważną rolę religii, ale równocześnie prezentowali pogląd, że jej znaczenie w nowoczesnych społeczeństwach będzie się zmniejszać. W tym kontekście ukształtowała się teoria (paradygmat) sekularyzacji, która wydawała się najbardziej odpowiednią do wyjaśniania zmian w religijności.

Przez wiele dziesięcioleci w socjologii dominowała teza sekularyzacyjna, według której następowała w społeczeństwach nowoczesnych autonomizacja różnych dziedzin życia społecznego, czyli wyzwalanie się poszczególnych sektorów

3 J. Beckford, Teoria społeczna a religia, tłum. M. Kunz, T. Kunz, Kraków 2006, s. 267.

4 A. Giddens, P.W. Sutton, Socjologia. Kluczowe pojęcia, tłum. O. Siara, P. Tomanek, Warszawa 2014, s. 22. 
społeczeństwa i kultury spod władzy instytucji i symboli religijno-kościelnych. Ten obiektywny proces przemian oddziaływał stopniowo na świadomość ludzi i przekształcenia $\mathrm{w}$ uniwersum religijnym. Religia traciła swoją dawną wiarygodność, popadała w różnorodne kryzysy. Tradycyjne religijne definicje rzeczywistości były zastępowane przez wyjaśnienia racjonalne, naukowe, techniczne. W tym kontekście proklamowano niekiedy tezę o zanikaniu religii, o słabnięciu społecznego stanu posiadania religii i nadchodzeniu bezreligijnego społeczeństwa, co rozwinęło się w końcu w globalną tezę sekularyzacyjną. W niektórych wersjach skrajnej tezy sekularyzacyjnej traktuje się religię jako przejaw epoki przednowoczesnej i wyraz irracjonalnego stylu życia. Nowoczesne społeczeństwa stają się niejako z konieczności świeckie. Sekularyzacja stała się tezą wyjaśniającą procesy dechrystianizacji społeczeństw Europy Zachodniej.

Relacja nowoczesności i religii była ujmowana według scenariusza kryzysu, a sekularyzację traktowano jako nieodłącznie związaną z modernizacją społeczną, powodującą spadek praktyk religijnych i obniżenie świadomości religijnej społeczeństwa. Część socjologów w XX w. ogłaszała triumf sekularyzacji („im bardziej zmodernizowane społeczeństwo, tym bardziej zsekularyzowane"). W warunkach postępujących techniczno-ekonomicznych i kulturowych procesów modernizacji, społeczeństwa stawały się coraz bardziej „odkościelnione” (spadek znaczenia Kościołów chrześcijańskich i osłabienie więzi kościelnych). Bez wątpienia napięcie między nowoczesnością a religią przyczyniło się do odchodzenia wielu ludzi od Kościołów chrześcijańskich $^{5}$.

5 G. Pickel, Religion, Religiosität, Religionslosigkeit und religiöse Indifferenz. Religionssoziologische Perspektiven im vereinigten Deutschland, 
Do niedawna przyjmowano w socjologii dość powszechnie tezę, że między modernizacją społeczną a religijnością istnieje współzależność, najczęściej jednokierunkowa: im więcej modernizacji, tym mniej religijności, im społeczeństwo jest bardziej modernizowane, tym bardziej zsekularyzowane. Fenomen sekularyzacji nie był kwestionowany, chociaż jego skutki były oceniane w zróżnicowany sposób. Zasadniczy problem można sformułować następująco, czy sekularyzacja jest nieodłączną cechą procesu modernizacji społecznej, czy też jest zjawiskiem - przynajmniej częściowo - od niego odrębnym? Stawianie takiego pytania jest usprawiedliwione do pewnego stopnia tym, że we współczesnym świecie, także częściowo i w Europie, ulegają zahamowaniu procesy sekularyzacyjne i coraz wyraźniej zaznacza się swoisty powrót religii w nowoczesnym świecie (rewitalizacja). Dominuje w socjologii teza o niemożności pogodzenia religijności z nowoczesnością (modernizacją). Są i tacy socjologowie, którzy prezentują tezę, że sekularyzacja jest niezależna od procesu modernizacji i że można być człowiekiem w pełni nowoczesnym i w pełni religijnym. Potrzebne są więc nowe paradygmaty i teorie uwzględniające tę sytuację.

Z socjologicznego punktu widzenia modernizację społeczną można opisywać na kilku płaszczyznach: wzrostu dobrobytu materialnego, demokratyzacji życia społecznego i politycznego, dyferencjacji strukturalnej i pluralizmu społeczno-kulturowego oraz analizować jej wpływ na religijność współczesną. Modernizacja społeczna nie musi prowadzić do coraz bardziej skutecznego usuwania religii z przestrzeni życia publicznego oraz ze świadomości ludzi, aż do jej całkowitego wygaszenia. W naszym referacie zwró-

[w:] Konfessionslosigkeit heute, Zwischen Religiosität und Säkularität, red. M. Rose, M. Wermke, Leipzig 2014, s. 47. 
cimy uwagę na relacje między modernizacją społeczną a religią (teza ogólna) oraz na relacje modernizacji społecznej i religii w Indonezji, zwłaszcza na islam, buddyzm i chrześcijaństwo (teza szczegółowa). Modernizacja społeczna nie musi prowadzić do coraz bardziej skutecznego usuwania religii z przestrzeni publicznej, aż do jej całkowitego wygaszenia. Do sytuacji w Indonezji nie pasują teorie socjologiczne, które powstawały w kontekście europejskim lub co najmniej wymagają one znacznej modyfikacji.

\section{Pojęcie modernizacji społecznej}

Ogólnie modernizacja to zbliżanie się społeczeństwa w sposób zamierzony, celowy, planowany do uznanego modelu nowoczesności. Jest nim najczęściej wzorzec jakiegoś istniejącego społeczeństwa uznanego za najbardziej rozwinięte ${ }^{6}$. Podstawowe założenia teorii modernizacji zostały wypracowane w socjologii zachodniej w latach 50. XX w. Modernizacja jako proces unowocześniania może być rozumiana na trzy sposoby: „1) upowszechnienie różnorodnych innowacji techniczno-technologicznych - zakłada się tu, że zmiany w technice powodują zmiany społeczne; 2) wszelkie zmiany (nie tylko technologiczne) prowadzące do nowocześniejszych i doskonalszych form organizacji danego społeczeństwa, jego gospodarki, polityki, kultury; 3) przekształcenie społeczeństwa typu tradycyjnego w społeczeństwo »nowoczesne«, utożsamiane zazwyczaj z społeczeństwem przemysłowym"?

6 P. Sztompka, Stownik socjologiczny. 1000 pojęć, Kraków 2020, s. 187.

7 A. Słaboń, Modernizacja, [w:] Słownik pojęć socjologicznych, red. M. Pacholski, A. Słaboń, Kraków 2010, s. 123. 
Przez modernizację społeczną rozumie się także ogół sytuacji, zjawisk i procesów społecznych, których analizy ułatwiają wyjaśnienie całościowego (globalnego) przekształcenia się społeczeństwa tradycyjnego (przednowoczesnego, przedprzemysłowego) w społeczeństwo nowoczesne i przemysłowe, a następnie w społeczeństwo postindustrialne (poprzemysłowe) i postnowoczesne (ponowoczesne). Wyróżnia się w tym procesie przekształceń kilka płaszczyzn (wymiarów): a) modernizacja ekonomiczna oznaczająca przewartościowanie i społeczną restrukturyzację sfery ekonomiczno-gospodarczej oraz rynku usług i wytwarzania (także podziału pracy), wprowadzenie nowych technologii, stylów i sposobów produkcji i pracy, a także nowoczesnego zarządzania; b) modernizacja kulturowa polega głównie na pojawieniu się w kulturze społeczeństwa tradycyjnego pluralizmu i sekularyzacji; c) modernizacja polityczna wyraża się w powstawaniu licznych partii politycznych, pojawienia się nowoczesnego parlamentu, wprowadzenia powszechnego prawa wyborczego oraz zróżnicowanych form głosowania i podejmowania decyzji politycznych; d) modernizacja społeczna oznacza przekształcenia prowadzące do industrializacji i urbanizacji, co wiąże się z osłabieniem lub zanikiem tradycyjnych autorytetów, z rozpadem dawnych struktur społecznych oraz rozpowszechnianiem się umiejętności czytania i pisania ${ }^{8}$.

Według Neil J. Smelsera cechą podstawową modernizacji jest zróżnicowanie strukturalne, czyli ustanowienie bardziej wyspecjalizowanych i autonomicznych jednostek społecznych, zróżnicowanie mechanizmów regulacyjnych we wszystkich sferach życia, zróżnicowanie się systemów

8 K. Olechnicki, P. Załęcki, Stownik socjologiczny, Toruń 2002, s. 132. 
wartości i społecznej stratyfikacji, zróżnicowanie się czynności rodzinnych. W wyniku modernizacji stary ład ulega dezaktualizacji, integracja nabiera nowego charakteru. Procesy te nie przebiegają jednakowo, zaznacza się pluralizm dróg rozwojowych w różnych krajach czy regionach. Różnice te dotyczą warunków poprzedzających modernizację, dynamiki zmian, dróg modernizacji, zwłaszcza na etapach zaawansowanej modernizacji, wystąpienia dramatycznych wydarzeń w okresie modernizacji (np. wojny, rewolucje, klęski żywiołowe). Różnorodne doświadczenia narodowe warunkują odmienność form uniwersalnych cech procesów modernizacji ${ }^{9}$.

W literaturze przedmiotu istnieje ogromna liczba najrozmaitszych definicji i twierdzeń dotyczących modernizacji, w których eksponuje się różne jej etapy, elementy składowe i korelaty. Za punkt odniesienia w naszych rozważaniach przyjmujemy zwięzłą charakterystykę procesu modernizacji za Markiem S. Szczepańskim. „Za naczelną charakterystykę strukturalną procesu modernizacji uznaje się dyferencjację, bezustanne zróżnicowanie. Proces różnicowania dokonuje się na wszystkich płaszczyznach, poczynając od osobowości jednostki poprzez płaszczyznę społeczną, kulturową, ekonomiczną, na politycznej kończąc. Proces ten polega na pojawianiu się nowych jakościowo, nowoczesnych, zmodernizowanych form organizacji w każdej z wymienionej dziedzin"10.

9 N.J. Smelser, Przyczynek do teorii modernizacja, [w:] Elementy teorii socjologicznych. Materiaty do dziejów wspótczesnej socjologii zachodniej, red. W. Derczyński, A. Jasińska-Kania, J. Szacki, Warszawa 1975, s. 324-326.

10 M.S. Szczepański, Modernizacja, [w:] Encyklopedia socjologii, t. 2, red. W. Kwaśniewicz, Warszawa 1999, s. 271. 
Europejska nowoczesność (modernizacja) nie jest jedyną, jest jedną z wielu odmian we współczesnym świecie. Wszystkie one podlegają procesom nieustannej rekonstrukcji. Z jednej strony mamy do czynienia z ciągłą ekspansją gospodarki, wynikającą z działania sił globalizacyjnych; z drugiej strony z rosnącym zaniepokojeniem stanem środowiska naturalnego, ryzykiem w jego różnych postaciach, a także z wzorcami życia połączonymi z lękiem i niepewnością. Dość powszechny jest obecnie pogląd, że nie istnieje już żaden uniwersalny model modernizacji, odnoszący się do wszystkich państw świata. W niektórych wizjach rozwoju podkreśla się, że rozwój powinien opierać się na zasobach i możliwościach konkretnych państw („poleganie na własnych siłach”, „samorozwój”), a działania zewnętrzne powinny jedynie go wspierać $\mathrm{i}$ katalizować pożądane procesy ${ }^{11}$.

\section{Modernizacja społeczna a religijność - zmienne relacje}

Od samego początku swego istnienia socjologia wiązała pozycję i rolę religii w społeczeństwie z procesami modernizacji. Wielu socjologów było przekonanych, że w wyniku procesów modernizacyjnych (zmiany cywilizacyjne, zmiany w strukturze społecznej, kultura masowa, nowe formy spędzania czasu wolnego, komercja i konsumpcja) następują zmiany sekularyzacyjne prowadzące do osłabienia, a nawet zanikania religii w życiu społecznym ${ }^{12}$. W ramach teorii modernizacji społecznej lansowano tezę o sekularyzacji, czyli

11 Ibidem, s. 274.

12 M. Wohlrab-Sahr, Religion, [w:] Lexikon Soziologie und Sozialtheorie. Hundert Grundbegriffe, red. S. Farzin, S. Jordan, P. Reclam jun, Stuttgart 2008, s. 238-241. 
o stopniowym zanikaniu religijności wiążącej się z warunkami tradycyjnymi odchodzącymi w przeszłość. „Odczarowanie świata”, jak to określał Max Weber, wiązało się z trzema procesami: a) z procesem racjonalizacji, czyli dominującej roli rozumu, nauki i argumentów empirycznych; b) z procesem zróżnicowania strukturalnego i funkcjonalnego prowadzącego do oddzielenia Kościoła, obrzędów i wiary od codziennego życia; c) zanik znaczenia religii wiąże się z modernizacją cywilizacyjną i zmianami struktury społecznej, przede wszystkim z masową kulturą, z atrakcyjnymi formami spędzania czasu wolnego, komercją i konsumpcją ${ }^{13}$.

Sekularyzacja jako zjawisko społeczne była i jest wyjaśniana głównie poprzez procesy modernizacji. Wskazywano także na takie przyczyny, jak industrializacja i urbanizacja, dyferencjacja społeczna, rozwój techniczny i ekonomiczny, rozpad tradycyjnych środowisk społecznych, pluralizm społeczno-kulturowy, rozwój nauki, procesy racjonalizacji, liberalizacja stosunków Kościół - państwo. Modernizacja społeczna oddziaływała $\mathrm{z}$ reguły negatywnie na religię i jej znaczenie w społeczeństwie, na atrakcyjność wspólnot religijnych, niosła ze sobą efekty sekularyzacyjne. W sytuacjach, w których ludziom żyje się coraz lepiej, trudniej jest im koncentrować się na tym, co przyjdzie w przyszłości („po tamtej stronie”). Niekiedy ujmowano wpływ modernizacji jako jednokierunkowy i nieodwracalny. Religię i religijność pojmowano jako zmienną zależną, poddaną wpływom wielu czynników społecznych i ekonomicznych, określanych terminem zbiorczym jako modernizacja społeczna.

Teoria sekularyzacji miała do pewnego stopnia charakter samospełniającego się proroctwa. Jeżeli nawet współcześnie

13 P. Sztompka, Socjologia. Analiza społeczeństwa, Kraków 2012, s. $372-373$. 
dochodzi do pewnego zahamowania procesów sekularyzacyjnych, to jest to zjawisko przejściowe - twierdzą zwolennicy nieuchronnego związku modernizacji społecznej i sekularyzacji. W końcu dojdzie do tego, że bycie nowoczesnym będzie z konieczności oznaczać bycie świeckim. Fakt, że do takiej sytuacji doszło tylko w niektórych częściach świata, nie podważa tezy o nieuniknionym i nieodłącznym związku między tymi procesami ${ }^{14}$. W nowoczesnym świecie postępuje proces słabnięcia roli i znaczenia religii, nie jest ona już potężną siłą, nowe formy religijności mają niewielki zakres i siłę oddziaływania. Co więcej, zachodnioeuropejską sekularyzację traktowano jako miarodajną reprezentację procesów globalnych.

Do niedawna przyjmowano w socjologii dość powszechnie tezę, że między modernizacją społeczną a religijnością istnieje współzależność, najczęściej jednokierunkowa: im więcej modernizacji, tym mniej religijności, im społeczeństwo jest bardziej modernizowane, tym bardziej zsekularyzowane. Dzisiaj coraz częściej mówi się o wielu odmianach modernizacji i tylko niektóre z nich łączą się nieuchronnie z sekularyzacją. Część socjologów w dalszym ciągu jednak zakłada niemożność pogodzenia religijności z nowoczesnością i modernizacją społeczną (sekularyzacja jako integralna część modernizacji). Według nich sekularyzacja jest zjawiskiem towarzyszącym modernizacji społecznej, jest do pewnego stopnia ogólnym trendem cywilizacyjnym. Sekularyzację uznano za coś pozytywnego, co należy po prostu przyjąć bez zastrzeżeń, a kulturową marginalizację religii jako proces nieunikniony i nieodwracalny ${ }^{15}$.

14 G. Davie, Socjologia religii, tłum. R. Babińska, Kraków 2010, s. 342 .

15 A. Kasperek, Teoria sekularyzacji i jej wrogowie. Próba apologii 
Współczesna modernizacja dopuszcza wiele dróg jej realizacji. Alain Tournaine mówi o jednej nowoczesności, ale o wielu ścieżkach prowadzących do modernizacji1 ${ }^{16}$. Europejska modernizacja społeczna jest jedną z nich, pierwszą, ale być może w przyszłości nie najważniejszą. Nie musi być także tak - jak głoszą dotychczasowe teorie modernizacji - że wraz z modernizacją społeczną ustępują całkowicie wartości tradycyjne na rzecz tego co nowoczesne. Niektóre wartości tradycyjne zachowują swoją trwałość, mimo pewnych przekształceń i modyfikacji. Zarówno modernizacja społeczna, jak i sekularyzacja przebiegają w różnych społeczeństwach na różne sposoby, nie ma pomiędzy nimi deterministycznych zależności. Teza sekularyzacyjna nie tłumaczy wszystkich aspektów dokonujących się przemian w religijności.

Modernizacja społeczna i związane z nią różnorodne trendy społeczne nie działają na jakiejś nieuchronnej i deterministycznej zasadzie, niezależnej od idei i działań ludzi. Nie ma takiej z góry ustalonej konieczności, według której nowoczesne społeczeństwa muszą być - niejako z natury - świeckie i niereligijne. Czy takimi się stają czy nie, zależy od decyzji ludzi, od ich świadomych wyborów, od niezamierzonych konsekwencji tych wyborów, od konkurencyjności i wpływów między rozmaitymi grupami, od rozmaitych kontekstów społeczno-kulturowych. Uwarunkowania zewnętrzne związane z dyferencjacją społeczną, dobrobytem, pluralizmem i indywidualizmem odgrywają pewną rolę współkształtującą kondycję religijną społeczeństw. Współ-

niepopularnej teorii, [w:] Między socjologia i teologia. Pola zainteresowań i badań naukowych Janusza Mariańskiego, red. J. Baniak, Poznań 2010, s. 218-220.

16 A. Touraine, Po kryzysie, tłum. M. Frybes, Lublin 2013, s. 83. 
czesne społeczeństwa nie są areligijne, tylko inaczej niż dawniej religijne ${ }^{17}$.

W warunkach poszerzającej się ustawicznie możliwości kształtowania własnego życia jednostka jest zmuszona podejmować wciąż nowe decyzje („od losu do wyboru”, upodmiotowienie, autonomia, emancypacja, samostanowienie). W codzienności ujawniają się nie tylko zinstytucjonalizowane formy religijności, ale i różnorodne formy nowej religijności i duchowości, które mogą charakteryzować zarówno członków, jak i nie, członków organizacji religijno-kościelnych. Można przyjąć założenie, że w warunkach modernizacji społecznej religijność nie upada, lecz podlega dynamicznym przemianom, zarówno w kierunku podtrzymywania konsensu religijnego, jak i dissensu. Z trzech konkurencyjnych hipotez: a) o utracie funkcji religii (przesuwanie się religii z życia społecznego do prywatnego); b) o zmierzchu, a nawet upadku religii (agnostycyzm, indyferentyzm, ateizm); c) o dynamice i transformacji form religijności, wydaje się, że najbardziej empirycznie uprawomocniona jest hipoteza trzecia.

W XXI w. socjolog amerykański Peter L. Berger wyrażał pogląd, że nowoczesność nie przyniosła ze sobą upadku religii, lecz doprowadziła do jej przekształceń. Nie jesteśmy świadkami upadku religii. Teoria sekularyzacji bazowała na założeniu, że modernizacja społeczna prowadzi nieuchronnie do zaniku religii. Socjologowie poddawali nadinterpretacji pewne fakty świadczące o sekularyzacji, także pluralizm społeczny i religijny interpretowano jako przejaw sekularyzacji. Teoria sekularyzacyjna przyjmowała - mniej lub bardziej wyraźnie tezę, że modernizacja społeczna prowadzi

17 J. Paulas, J. Šebek (red.), Anselm Grün odpowiada na pytania, tłum. J. Zychowicz, Kraków 2003, s. 157. 
nieuchronnie do zaniku religii. Na podstawie wyników badań socjologicznych ta teoria już dzisiaj w swojej klasycznej formie jest nie do utrzymania, potrzebujemy dzisiaj innego paradygmatu, a jest nim teoria pluralizmu, opierająca się na koegzystencji różnych religii i koegzystencji sekularnego oraz religijnego dyskursu ${ }^{18}$. Przykład Indonezji wydaje się potwierdzać tezę Petera L. Bergera. Pomimo znaczących postępów modernizacyjnych sytuacja religijna w Indonezji nie uległa pogorszeniu, co więcej istnieje wiele oznak desekularyzaji, np. w katolicyzmie. Religie są jednym z ważnych filarów życia publicznego.

Świat współczesny charakteryzuje nie tyle sekularyzacja, ile raczej ważniejszy od niej fenomen pluralizacji religijnej. „Podstawowe procesy modernizacji - takie jak powszechne szkolnictwo, urbanizacja, rozwój środków masowego przekazu - prowadzą do współwystępowania obok siebie na pokojowych warunkach różnych punktów widzenia i systemów wartości. To niezwykle ważne zjawisko, które zmienia naturę religii, ale niekoniecznie jest tożsame z jej zanikiem. Pluralizm i rozmnożenie dostępnych możliwości oraz związana z tym konieczność wyboru nie muszą prowadzić do wyboru laicyzmu. Równie dobrze człowiek nowoczesny może wybrać religię choć warunki, w jakich tego dokonuje, zmieniają zarówno strukturę instytucjonalną poszczególnych kościołów, jak również indywidualne doświadczenie religijne. [...]. Żadna tradycja religijna czy kulturowa nie jest już uznawana za niepodważalny pewnik. Zamiast tego nieustannie podlega kwestionowaniu, czyli innymi słowy zostaje zrelatywizowana. To bardzo powszechne zjawisko,

18 P.L. Berger, Altäre der Moderne. Religion in pluralistischen Gesellschaften, Frankfurt am Main 2015, s. 7. 
nie tylko w Europie"19. Nowoczesność prowadzi do pluralizmu, który podważa oczywistość religijną, ale otwiera również mnóstwo poznawczych i normatywnych możliwości wyboru. Pluralizm jest dla wiary ważnym wyzwaniem, ale nie musi on prowadzić do sekularyzacji. Pluralizm religijny rozwija się na płaszczyźnie indywidualnej i zbiorowej (kolektywnej), ma swoje różnorodne oblicza.

W warunkach pluralizmu społeczno-kulturowego tożsamość religijna nie jest we współczesnym świecie tym, co jest dane, lecz tym, co jest zadane. Jednostki samodzielnie konstruują własne tożsamości, swoje światopoglądy, swój system wartości moralnych. Pluralizm społeczny oraz jego społeczna i psychologiczna dynamika sprawiają, że jednostkom coraz trudniej jest utrzymać pewność światopoglądową, nie angażując się w nieustanny proces walki z samym sobą i światem zewnętrznym. Religijność przestaje być częścią kulturowego dziedzictwa, wybór religii staje się świadomą decyzją jednostki. W warunkach ponowoczesności tożsamości religijne są mocno zróżnicowane.

Modernizacja społeczna nie tyle niszczy, co przekształca religię i religijność. „Podstawowe procesy modernizacji - takie jak powszechne szkolnictwo, urbanizacja, rozwój środków masowego przekazu - prowadzą do współwystępowania obok siebie na pokojowych warunkach różnych punktów widzenia i systemów wartości. To niezwykle ważne zjawisko, które zmienia naturę religii, ale niekoniecznie jest tożsame z jej zanikiem. Pluralizm i mnożenie dostępnych możliwości oraz związana z tym konieczność wyboru nie muszą prowadzić do laicyzmu. Równie dobrze człowiek

19 Religia i nowoczesność. Rozmowa $z$ amerykańskim socjologiem religii Peterem Bergerem, „Europa. Miesięcznik Idei” 2012, nr 5, s. 24. 
nowoczesny może wybrać religię, choć warunki, w jakich tego dokonuje, zmieniają zarówno strukturę instytucjonalną poszczególnych kościołów, jak również indywidualne doświadczenie religijne. Człowiek wybiera dziś religię bardziej samodzielnie niż jeszcze kilkadziesiąt lat temu. Robert Wuthnow, amerykański socjolog religii z Uniwersytetu Princeton, bardzo trafnie określa to zjawisko mianem »kolażu religijnego« [...]. Żadna tradycja religijna czy kulturowa nie jest już uznawana za niepodważalny pewnik. Zamiast tego nieustannie podlega kwestionowaniu, czyli innymi słowy zostaje zrelatywizowana. To bardzo powszechne zjawisko, nie tylko w Europie"20.

Jeżeli nawet modernizacja społeczna nie zawsze prowadzi do wyraźnych i postępujących procesów sekularyzacyjnych, to jej obecność we współczesnym świecie nie może podlegać zakwestionowaniu. Także teorie sekularyzacyjne w swoich zmodyfikowanych kształtach są w dalszym ciągu przydatne $\mathrm{w}$ wyjaśnianiu zmian $\mathrm{w}$ religijności, ale nie na zasadzie jedynego paradygmatu. Wielokierunkowe zmiany w religijności współczesnej wymagają wielu modeli wyjaśniających. Socjologia religii jest nauką wieloparadygmatyczną, a teoria sekularyzacji może być także przydatna $\mathrm{w}$ interpretacjach transformacji religijnych we współczesnym świecie. Trzeba jednak wyraźnie podkreślić, że różne postaci modernizacji społecznej korespondują z różnymi formami zmian w religijności. Jeżeli nawet modernizacja społeczna w pewnych państwach przyczyniała się do osłabienia religijności, to z drugiej strony oznacza ona zwiększoną różnorodność i pluralizm, co wywiera na ogół pozytywny wpływ na religijność.

20 Ibidem, s. 24. 


\section{Religie w Indonezji}

Indonezja jest olbrzymim archipelagiem, rozciągającym się od Oceanu Indyjskiego po Nową Gwineę i od kontynentu azjatyckiego po Australię. Kraj jest złożony z ponad 13487 wysp położonych wokół równika. Około 3 tys. spośród nich jest zamieszkałe. Zarówno etniczne, jak i językowo Indonezja jest ogromnie zróżnicowana. Szacuje się, że liczba grup etnicznych waha się od 300 do 500, z których każda ma swój język i swoją kulturę. W 2010 r. - według spisu ludności liczba mieszkańców wynosiła $237556363^{21}$.

Religia w Indonezji odgrywa ważną rolę w życiu ludzi. Stwierdza się to w ideologii narodu indonezyjskiego, Pancasila. Jest to kompromis między ideą państwa islamskiego a państwem świeckim. Pancasila zawiera pięć zasad: wiara w jedynego Boga, sprawiedliwy i oświecony humanitaryzm, jedność Indonezji, demokracja oparta na wewnętrznej mądrości przywódców i ich otwartość na dyskusję, sprawiedliwość społeczna dla wszystkich obywateli. Można je traktować jako sposób życia Indonezyjczyków, jako filozofię Republiki Indonezji lub jako narodową ideologię ${ }^{22}$.

Wiele religii w Indonezji ma zbiorowy wpływ na politykę, gospodarkę i kulturę. Według wyników indonezyjskiego spisu ludności z 2010 r., 87,18\% ludności Indonezji to muzułmanie (Nusantara jest regionem o największej populacji

21 J. Glinka, Sto lat Werbistów w Indonezji, „NURT SVD” 2014, nr 2, S. 190.

22 M. Arenhövel, Die Erfindung der Panacasila. Zur Konstruktion einer staatsreligiösen Einheitsvision in Indonesien, [w:] Unfriedliche Religionen, red. M. Hildebrandt, Wiesbaden 2005 s. 139-152; J. Wojnowski (red.), Wielka encyklopedia PWN, t. 12, Warszawa 2002, s. 97. 
muzułmanów na świecie), 6,96\% chrześcijanie protestanccy, 2,90\% chrześcijanie katoliccy, 1,69\% hindusi, 0,72\% buddyści, 0,05\% konfucjanie, 0,13\% inne religie, a 0,38\% pominięci lub niezapytani ${ }^{23}$. Konstytucja z 1945 r. stanowi, że „każdy obywatel otrzymuje wolność wyboru i praktykowania swojej wiary” i „gwarantuje wszelką wolność kultu, zgodnie z jego religią lub przekonaniami"24.

W dekrecie prezydenckim nr 1 z 1965 r. dotyczącym zapobiegania nadużyciom i/lub bluźnierstwom religii, oficjalnie uznaje się jednak tylko sześć religii, a mianowicie: islam, protestantyzm, katolicyzm, hinduizm, buddyzm i konfucjanizm $^{25}$. Ostatnio system przekonań (religia ojczysta archipelagu) został również uznany zgodnie z orzeczeniem Trybunału Konstytucyjnego Republiki Indonezji z 7 listopada 2017 r. ${ }^{26}$ Ze względu na liczbę religii i przekonań w Indonezji, konflikty między religiami są często nieuniknione. Co więcej, przywództwo polityczne Indonezji odgrywa ważną rolę w stosunkach między grupami religijnymi. Program transmigracji pośrednio spowodował szereg konfliktów we wschodniej Indonezji.

\section{Historia}

Aż do początku ery chrześcijańskiej ludność archipelagu (grupy etniczne australijskie i papuańskie) podążała za prze-

23 Badan Pusat Statistik. Jakarta, 15.05.2010.

24 Undang-undang Dasar 1945, Konstytucje Narodowe z 1945 roku.

25 Dian A.H. Shah, Constitutions, Religion and Politics in Asia: Indonesia, Malaysia and Sri Lanka, Cambridge-London 2017.

26 R.A. Siregar, „Kebijakan Publik bila Mencantumkan Aliran Kepercayaan dalam Admininistrasi Kependudukan sebagai Bentuk Revitalisasi Pancasila" (PDF); L. Naibaho, D. Jura, Revitalisasi Indonesia melalui Identitas Kemajemukan Berdasarkan Pancasila, Jakarta 2018, s. 173-77. 
konaniami i zwyczajami rdzennych plemion. Z historycznego punktu widzenia, grupy imigrantów były główną siłą napędową różnorodności religijnej i kulturowej w kraju, z imigrantami z subkontynentu indyjskiego, Chin, Portugalii, Arabii i Holandii. Zmieniło się to jednak od czasu wprowadzenia kilku zmian w kulturze Indonezji. Świątynia Prambanan - wielkie piękno hinduizmu w Jawie Środkowej - powstała w IX w. Hinduizm i buddyzm zostały sprowadzone do Indonezji ok. II i IV w. n.e., kiedy to handlarze z Indii przybyli na Sumatrę, Jawę i Sulawesi ze swoją religią. Hinduizm zaczął się rozwijać na wyspie Jawa w piątym wieku n.e. $\mathrm{z}$ kastą Braminów, którzy czcili Sivę. Handlarze rozwinęli również buddyzm w kolejnych wiekach, a wiele buddyjskich i hinduistycznych nauk wpłynęło na bogate królestwa, takie jak Kutai, Sriwijaya, Majapahit i Sailendra.

Największa świątynia buddyjska na świecie, Borobudur, została zbudowana przez Królestwo Sailendry w tym samym czasie, podobnie jak hinduistyczna świątynia, Prambanan. Szczyt hinduistyczno-jawajskiej chwały, Królestwo Majapahit, przypadł na XIV w. n.e., który był również złotym wiekiem $\mathrm{w}$ historii Indonezji ${ }^{27}$. Hinduizm miał decydujący wpływ na ideologię jednego z rządów króla ${ }^{28}$. Islam wszedł do Indonezji w XIII w. za pośrednictwem handlarzy w Gudżaracie w Indiach, natomiast naukowcy podtrzymują teorię, że przybyli oni także z Arabii i Persji. Islam rozprzestrzenił się na zachodnie wybrzeże Sumatry, a następnie rozwinął się na wschód od wyspy Jawa. W tym okresie

27 A.Andrea, H. Creese, A. Griffiths, From Lanka Eastwards: The Ramayana in the Literature and Visual Arts of Indonesia, Leiden 2011.

28 R. Heine-Geldern, Conceptions of State and Kingship in Southeast Asia. Southeast Asia Program Publications of Cornell University, Ithaca-New York 1956. 
istniało kilka królestw islamskich, a mianowicie królestwa Demaka, Pajanga, Matarama i Bantena. Pod koniec XV w. n.e. powstało dwadzieścia imperiów islamskich, odzwierciedlających dominację islamu w Indonezji ${ }^{29}$.

Chrześcijaństwo, czyli Kościół Wschodnioazjatycki z Nestorianizmem, było obecne na archipelagu na Sumatrze Północnej w VII w. ${ }^{30}$ Dokument Abu Salih al-Arminiego stwierdza, że miasto Barus, które wcześniej było znane jako Pancur, a obecnie znajduje się na terenie diecezji Sibolga na Sumatrze Północnej, jest siedzibą najstarszych katolików w Indonezji. W Barus powstał również Kościół o nazwie Bunda Perawan Murni Maria ${ }^{31}$. Katolicyzm został sprowadzony do Indonezji za sprawą Portugalczyków, szczególnie na wyspach Flores i Timor ${ }^{32}$. Protestantyzm został po raz pierwszy wprowadzony przez Holendrów w XVI w. n.e. pod wpływem nauk kalwińskich i luterańskich. Animistyczne obszary wschodniej Indonezji, jak i inne, były głównymi celami podróży Holendrów, w tym Moluki, Nusa Tenggara, Papua i Kalimantan. Później chrześcijaństwo rozprzestrzeniało się poprzez porty przybrzeżne Borneo, misjonarze przybyli do Toradża, Sulawesi. Obszar Sumatry był w tym czasie również celem dla misjonarzy, szczególnie dla ludu Bataków, z których wielu jest obecnie protestantami ${ }^{33}$.

29 M.C. Ricklefs, Polarising Javanese society: Islamic and other visions c. 1830-1930, Honolulu, Hawaii 2007.

30 J. Aritonang, J.S. (Pdt. Dr. Jan S. Aritonang), Berbagai aliran di dalam dan di sekitar gereja, Singapore 1995, s. 11.

31 Kościót Katolicki w Indonezji, seria 1, wydany przez KWI.

32 Huub J.W.M. Boelaars, Indonesianisasi, dari Gereja Katolik di Indonesia menjadi Gereja Katolik Indonesia, Yogyakarta 2005.

33 K. Steenbrink, Catholics in Indonesia: A documented history 1808-1942, t. 2: The Spectacular Growth of a Self Confident Minority, 1903-1942, Leiden 2007. 
Okres tzw. Starego Porządku (Orde Lama) pod prezydenturą Sukarno (od 1945 do 1965 r.) był zakłóceniem relacji między religią a państwem ${ }^{34}$. Istotne zmiany w religiach nastąpiły również w okresie Nowego Porzadku, czyli Orde Baru pod militarną dyktatura Suharto. W latach 1964-1965 napięcia między komunistyczną partią, znana jako PKI (Partai Komunis Indonesia), a rządem indonezyjskim, wraz z kilkoma organizacjami, doprowadziły do najcięższych konfliktów i zabójstw XX w. Na podstawie tych wydarzeń rząd Suharto próbował rozprawić się ze zwolennikami PKI, prowadząc politykę, która wymagała od każdego wyboru religii, ponieważ większość zwolenników PKI była ateistami. W rezultacie każdy obywatel Indonezji jest zobowiązany do posiadania przy sobie dowodu osobistego, który identyfikuje jego religię. Polityka ta doprowadziła do masowej konwersji religii, z których większość nawróciła się na chrześcijaństwo protestanckie i katolickie. Ponieważ konfucjanizm nie jest identyfikatorem religijnym, wielu Chińczyków nawróciło się również na chrześcijaństwo lub buddyzm ${ }^{35}$.

\section{Glówne religie Indonezji}

Na podstawie wyjaśnienia dekretu prezydenckiego $\mathrm{nr} 1$ z 1965 r. dotyczącego zapobiegania nadużyciom i/lub bluźnierstwom religii: „Religie przyjęte przez ludność Indonezji to islam, chrześcijaństwo prostestanckie, katolicyzm, hinduizm, buddyzm i konfucjanizm" (art.1).

34 B.F. Intan, Public religion and the Pancasila-based state of Indonesia: an ethical and sociological analysis, New York 2006, s. 44-50.

35 J. Bertrand, Nationalism and Ethnic Conflict in Indonesia, Cambridge 2004, s. 34-104. 


\section{Islam}

Indonezja jest krajem o największej populacji muzułmanów na świecie, gdzie $87,18 \%$ ludności to wyznawcy nauk islamskich ${ }^{36}$. Większość muzułmanów znajduje się w zachodniej Indonezji (np. na Jawie i Sumatrze), aż po tereny przybrzeżne wyspy Kalimantan (Borneo). Tymczasem we wschodniej Indonezji odsetek wyznawców nie jest tak duży, jak w regionie zachodnim ${ }^{37}$. Historia islamu w Indonezji jest bardzo złożona i odzwierciedla tę różnorodność kulturową. W XIII w. większość muzułmańskich kupców z Gujarat w Indiach przybyła na wyspy Sumatra, Jawa i Kalimantan (np. około 1297 r. istniało zgromadzenie w Peureulak we wschodnim Aceh). Dominujące hinduskie i buddyjskie królestwa, takie jak Majapahit i Srivijaya, utraciły swoje wpływy, a wielu wyznawców przeszło na islam. Część hinduistów wyemigrowało na Bali, część Jawy i Sumatry.

W niektórych przypadkach nauki islamskie w Indonezji są praktykowane $\mathrm{w}$ innej formie $\mathrm{w}$ porównaniu $\mathrm{z}$ islamem na Bliskim Wschodzie ${ }^{38}$. Absolutna większość, około 98\% muzułmanów w Indonezji, to wyznawcy sunnickiej sekty szkoły Shafi'i i kilku innych szkół sunnickich oraz ruchu Salafi ${ }^{39}$. Dwa główne kierunki sunnickie to islam tradycjonalistyczny (np. organizacja Nahdlatul ,Ulama') i modernizm islamski (Muhammadiyah i inne). Istnieje szereg tarekatów

36 N. Laskowska, Indonezja, Warszawa 2012, s. 153-155.

37 A. Azyumardi, Islam in the Indonesian World: An Account of Institutional Formation, Bandung 2006, s. 31-42.

38 C. Geertz, Abangan, santri, priyayi: dalam masyarakat Jawa [Religion of Java], Jakarta 1960.

39 B. Hauser-Schäublin, D.D. Harnish (red.), Between Harmony and Discrimination. Negotiating Religious Identities within Majority-minority Relationships in Bali and Lombok, Leiden 2004. 
z sufizmu (sufizm). W niektórych obszarach ludzie kontynuowali swoje stare wierzenia i przyjęli synkretyczną wersję islamu, na przykład Abangan na Jawie ${ }^{40}$.

\section{Shia}

Szyici w Indonezji odegrali ważną rolę we wczesnym okresie rozprzestrzeniania się islamu na Sumatrze Północnej (Aceh). Obecnie reszta, ponad 1\% wyznawców, czyli 1-3 mln osób, to Syiasz z Dwunastu Imamów, szyici w Indonezji mieszkają na Sumatrze, Jawie, Madurze i Sulawesi, a także szkoła Ismaili na Bali, np. wśród arabsko-indyjskiej subpartyfikatu Hadhrami ${ }^{41}$. Głównym stowarzyszeniem jest „Indonezyjskie Stowarzyszenie Ahlulbait Jamaah" (IJABI).

\section{Ahmadiyyah}

Ahmadiyyah w Indonezji Istnieje również około 400 tys. $(0,2 \%)$ członków sekty Ahmadiyyah („Indonezyjska Wspólnota Muzułmańska Ahmadiyya, JMAI"), których obecność była ostatnio często kwestionowana. Ahmadiyyah w Indonezji jest obecna od 1925 r. W dniu 9 czerwca 2008 r. rząd Indonezji wydał dekret praktycznie zakazujący Ahmadiyah prowadzenia działalności poza granicami kraju. Dekret ten stanowil, że Ahmadiyah ma zakaz rozpowszechniania swoich nauk ${ }^{42}$. Oddzielny od Ahmadiyiya Ruch Ahmadiyah Lahore Indonesia (GAI) znajduje się na Jawie od 1924 r.

40 M. Woodward, Java, Indonesia and Islam, Dordrecht 2011; A.M. Maćkowiak, Religijno-etniczny pluralizm w Indonezji. Przykład Lomboku, „Przegląd Kulturoznawczy” 2016, nr 4, s. 420-434.

41 J. Frode, Hadrami Arabs in Present-day Indonesia, London 2009, S. 19.

42 Burhani Ahmad Najib, The Ahmadiyya and the Study of Comparative Religion in Indonesia: Controversies and Influences, „Islam and Christian-Muslim Relations" 2014, nr 2, s. 141-158. 


\section{Hinduizm}

Kultura i religia hinduska pojawiły się w Indonezji w I w. n.e. wraz z pojawieniem się buddyzmu, który później zaowocował powstaniem wielu królestw hindusko-buddyjskich, takich jak Kutai, Mataram i Majapahit. Świątynia Prambanan to hinduska świątynia, która została zbudowana w czasach królestwa Majapahitów, za czasów dynastii Sandżaja. Królestwo to funkcjonowało aż do XVI w. n.e., kiedy to islamskie imperium zaczęło się rozwijać. Okres ten, znany jako Archipelag Hindusko-Buddyjski, trwał pełne szesnaście wieków ${ }^{43}$. Hinduizm w Indonezji różni się od innych hinduistów na świecie. Na przykład hinduizm w Indonezji, formalnie oznaczony jako religia hinduskiej Dharmy, nigdy nie przyjął systemu kastowego. Innym przykładem jest to, że hinduskie eposy religijne Mahabharata (Bitwa Potomków Bharaty) i Ramajana (Podróż Ramy) są ważnymi tradycjami wyznawców hinduizmu w Indonezji, które wyrażają się w postaci wayangu i przedstawień tanecznych. Wszyscy praktykujący hinduską Dharmę podzielają przekonania wielu zwykłych ludzi, z których większość to Pięć Wyznań Panca Srada. Obejmuje to wiarę w jednego Wszechmogącego Boga, wiarę w duszę i ducha oraz karmę lub wiarę w karę wzajemnego działania. Zamiast wiary w cykl odrodzenia i reinkarnacji, hinduizm w Indonezji jest bardziej związany z wielością pochodzenia duchowych przodków. Ponadto hinduizm skupia się tutaj bardziej na sztuce i ceremoniach religijnych niż na Piśmie Świętym, prawie i wierze ${ }^{44}$.

43 A.R. Kinney, M.J. Klokke, L. Kieven, Worshiping Siva and Buddha: The Temple Art of East Java, Honolulu, Hawaii 2003, s. 17-20.

44 D.J. Stuart-Fox, Pura Besakih: Pura, agama, dan masyarakat Bali [Pura Besakih: Temple, religion and society in Bali], Jakarta 2002. 
Według danych, liczba hinduistów w Indonezji w 2010 r. wynosiła 4 mln osób, co stanowiło 1,7\% ludności tego kraju i było czwartym co do wielkości wyznań religijnych. Liczba ta została jednak zakwestionowana przez przedstawicieli hinduizmu, którzy szacowali, że w Indonezji jest $10 \mathrm{mln}$ hinduistów. Zdecydowana większość hinduistów mieszka na Bali i jest zjednoczona w Indonezji paryskiej Dharmy Hinduskiej (PHDI). Oprócz Bali, są oni też na Sumatrze, Jawie (zwłaszcza w rejonie Jabodetabek), Lombok, Kalimantan i Sulawesi, która ma także sporą populację balijskich imigrantów. Innym ważnym skupiskiem hinduistów jest tamilskie plemię Indyjsko-Indonezyjczyków w Medan. W środkowej części Kalimantanu żyje hinduski lud Kaharingan, rdzenna religia ludów Dayak, które są włączone do hinduizmu (nie wszyscy wyznawcy się z tym zgadzają). Istnieje również jawajski hinduizm plemienia Tengger, hinduski Tołotang plemienia Bugis oraz Aluk Todolo z plemienia Toraja. Jawajski hinduizm został ukształtowany w inny sposób, tak że jest bardziej pod wpływem ich własnej wersji islamu, znanej jako islam Abangan lub islam Kejawen. Istnieje również kilka międzynarodowych ruchów Neo-Vedanta/Neohindu, takich jak International Society of Krishna Consciousness i organizacje Sathya Sai Baba, Chinmaya Mission, Brahma Kumaris, Ananda Marga, Sahaja Yoga i Haidakhandi Samaj.

\section{Buddyzm}

Buddyzm jest drugą najstarszą religią w Indonezji, pojswił sie tu ok. V w. n.e. lub wcześniej wraz z działalnością handlową, która rozpoczęła się na początku I w. Szlakiem Jedwabnym między Indiami a archipelagiem. Historia buddyzmu w Indonezji jest ściśle związana z historią hindu- 
izmu, wokół tego samego okresu powstało wiele buddyjskich królestw: Sailendra, Sriwijaya i Mataram. W Indonezji można znaleźć wiele dziedzictw, w tym świątynię Borobudur i posągi lub napisy z wcześniejszej historii królestwa buddyjskiego ${ }^{45}$. W połowie lat 60 . ubiegłego wieku Pancasila ponownie podkreślił uznanie jednego Boga (monoteizm). W rezultacie założyciel Perbuddhi (Indonezyjskiego Stowarzyszenia Buddystów), Bhikku Ashin Jinarakkhita, zaproponował istnienie jednego najwyższego bóstwa, Sanghyang Adi Buddy i jednej zjednoczonej sekty Buddhayana. Jest to poparte historią stojącą za indonezyjską wersją buddyzmu w przeszłości według starożytnych rękopisów jawajskich oraz kształtem świątyni Borobudur ${ }^{46}$.

Wśród indonezyjskich buddystów znajdują się wszystkie główne tradycje buddyjskie: Mahajana, Wajrayana i Theravada. Większość Chińczyków-Indonezyjczyków podąża za synkretycznym prądem z chińskimi wierzeniami, a mianowicie, Tridharmą i Ikuanizmem (Maytreya) ${ }^{47}$. Według narodowego spisu ludności z 2000 r., około 2\% całkowitej populacji Indonezji to buddyści, czyli około $4 \mathrm{mln}$ osób. Większość buddystów mieszka w Dżakarcie, choć są też inne prowincje, takie jak Riau, Sumatra Północna i Borneo Zachodni. Liczba ta może być jednak zbyt duża, biorąc pod uwagę, że konfucjanizm (do 1998 r.) i taoizm nie są uważane

45 A.R Kinney, M.J. Klokke, L. Kieven, Worshiping Siva and Buddha: The Temple Art of East Java, Honolulu, Hawaii 2003, s. 17-20.

46 B. Kimura, Present Situation of Indonesian Buddhism: In Memory of Bhikkhu Ashin Jinarakkhita Mahasthavira, „Nagoya Studies in Indian Culture and Buddhism: Sambhasa" 2003, nr 23, s. 53-72.

47 B. Hauser-Schäublin, D.D. Harnish (red.), Between Harmony and Discrimination. Negotiating Religious Identities within Majority-minority Relationships in Bali and Lombok, Leiden 2014, s. 84-112. 
za oficjalne religie w Indonezji, a więc w spisie powszechnym są uważane za buddystów ${ }^{48}$.

\section{Konfucjanizm}

Konfucjanizm wywodzi się z Chin kontynentalnych i został sprowadzony przez chińskich handlarzy i imigrantów, pochodzących z III w. naszej ery. W przeciwieństwie do innych religii, konfucjanizm skupia się bardziej na indywidualnych przekonaniach i praktykach, niż na kodeksie etycznym ${ }^{49}$. W 1883 r. w Surabaya powstało konfucjańskie miejsce kultu - Boen Tjhiang Soe, a później Boen Bio (Wen Miao). W 1900 r. konfucjanie utworzyli konfucjańską instytucję Khong Kauw Hwee. A Indonezyjska Wysoka Rada Konfucjańska (MATAKIN) powstała w 1955 r. w Surakarcie ${ }^{50}$. Po odzyskaniu niepodległości przez Indonezję w 1945 r., społeczność Konfucjan w Indonezji została uwikłana w kilka politycznych zamieszek i została wykorzystana do kilku celów politycznych. W 1965 r. Soekarno wydał dekret prezydencki nr 1 / Pn.Ps / 19651 / Pn.Ps / 1965, według którego jest sześć oficjalnych religii w Indonezji, w tym konfucjanizm. Soeharto wydał instrukcję prezydencką nr 14/1967, dotyczącą chińskiej kultury, kultu, chińskich uroczystości i wzywającą Chińczyków do zmiany prawdziwych nazwisk.

48 A. Syukur, Keterlibatan etnis Tionghoa dan agama Buddha: Sebelum dan Sesudah Reformasi 1998, [w:] Wibowo dan Thung Ju Lan, red. Lan, Thung Ju. Setelah air mata kering: masyarakat Tionghoa pasca-peristiwa Mei 1998, Jakarta 2010, s. 105-38.

49 Tong Cheu Hock, Chinese Beliefs and Practices in Southeast Asia: Studies on the Chinese Religion in Malaysia, Singapore and Indonesia, Singapore 1999..

50 Leo Suryadinata, Buddism and Confucianism in Contemporary Indonesia: Recent Developments, [w:] Chinese Indonesians: Remembering, Distorting, Forgetting, red. T. Lindsey, H. Pausacker, Singapore 2005, s. 77-94. 
Jednak wiedział on jak kontrolować Chińczyków-Indonezjan, którzy stanowili zaledwie 3\% ludności Indonezji, ale mieli dominujący wpływ na indonezyjską gospodarkę. W tym samym roku Soeharto stwierdził na konferencji PKTHI, że „konfucjanizm ma prawo do odpowiedniego miejsca w kraju".

W 1969 r. została wydana ustawa nr 5/1969 - zastępująca dekret prezydencki z 1967 r. - dotycząca sześciu oficjalnych religii. Różni się ona jednak w praktyce. W 1978 r. minister spraw wewnętrznych wydał dekret, w którym uznał, że jest tylko pięć oficjalnych religii, z wyłączeniem konfucjanizmu. W dniu 27 stycznia 1979 r. na posiedzeniu rządu zdecydowano, że konfucjanizm nie jest religią. Dekret ministra spraw wewnętrznych wydany w 1990 r. potwierdził, że w Indonezji istnieje tylko pięć oficjalnych religii. Dlatego też status konfucjanizmu w Indonezji w czasach Nowego Zakonu nigdy nie był jasny. Prawo wyższe zezwala na konfucjanizm, ale prawo niższe go nie uznaje. De facto konfucjanizm nie jest uznawany przez rząd i jego wyznawcy są zobowiązani do nawrócenia się na inne religie (zwykle chrześcijaństwo lub buddyzm), aby utrzymać swoje obywatelstwo. Praktyka ta jest stosowana $\mathrm{w}$ wielu sektorach, $\mathrm{w}$ tym $\mathrm{w}$ dowodach osobistych, $\mathrm{w}$ rejestracji małżeństw, a nawet w edukacji obywatelskiej w Indonezji, która wprowadza tylko pięć z nich.

\section{Tradycyjne religie}

Istnieje pewna liczba przodków australijskich grup etnicznych, które dominowały na całym archipelagu przed wejściem obcych religii. Niektóre z nich nadal żyją jako czyste lub synkretyczne zwyczajowe przekonania, a mianowicie: Adat Musi (plemię Talaud); Aluk Todolo (plemię Toraja); Arat Sabulungan (plemię Mentawai, szczególnie Sakuddei); 
Asmat (plemię Asmat); Jingi Tiu (plemię Sabu); Kaharingan (plemię Dayak); Kejawen (jawajskie); Marapu (plemię Sumba); Masade (plemię Sangir); Naurus (plemię Manusela); Parmalim (plemię Batak); Pelebegu (plemię Nias); Pemena (plemię Batak Karo); Sunda Wiwitan (plemię Sundanese, zwłaszcza Kanekes uranu); Tolotang (plemię Bugis); Tonaas Walian (plemię Minahasa); Wetu Telu (plemię Sasak); Wor (plemię Biak) ${ }^{51}$. Liczba tych nieoficjalnych wiernych w Indonezji sięga $20 \mathrm{mln}$.

Religia przodków zawiera animizm, wiarę w przedmioty nieożywione, wiarę w pewne przedmioty, takie jak drzewa, ryż, kamienie czy ludzie. Wiara ta istniała w najwcześniejszej historii Indonezji, ok. I w., tuż przed przybyciem hinduizmu do tego kraju. Mimo pojawienia się islamu, chrześcijaństwa, hinduizmu, buddyzmu, konfucjanizmu i innych religii wielbiciele przedmiotów martwych nadal pozostają w kilku regionach Indonezji. Natomiast czciciele przedmiotów martwych nie wierzą w niektórych bogów.

Istnieje jeszcze kilka innych religii i wierzeń w Indonezji, a mianowicie: sikhizm, dżinizm, judaizm, bahaizm, taoizm i tradycyjne wierzenia chińskie oraz nowe ruchy religijne, takie jak teozofia ${ }^{52}$.

\section{Żydzi}

Wczesne osadnictwo żydowskie na tym archipelagu pochodziło z Portugalii i Hiszpanii (Sefardyjczycy) w XVII w. W XIX w. Żydzi z Holandii, Niemiec i Indii zajmowali się handlem przyprawami i mieszkali w Dżakarcie, Semarangu

51 C. Geertz, Religion of Java, Glencoe, IL 1960.

52 I. Popov, Buku rujukan semua aliran dan perkumpulan agama di Indonesia, Singaraja 2017, s. 105-113. 
(subetniczni Żydzi aszkenazyjscy) i Surabai (Sefardyjczycy i Mizrachijczycy bagdadzcy). W 1945 r. w Indonezji mieszkało około 2 tys. holenderskich Żydów. W 1957 r. odnotowano, że w Dżakarcie i Sefardimie w Surabai było jeszcze około 450 Żydów, głównie aszkenazyjskich. W 1963 r. społeczność została zredukowana do 50 osób. W 1997 r. w Dżakarcie było tylko 20 Żydów, część z nich w Dżakarcie, a kilka rodzin Bagdadim w Surabai. Żydzi w Surabai posiadali kiedyś synagogę (miejsce kultu). Mieli niewielki kontakt z Żydami spoza Indonezji. W synagodze nie świadczono żadnych usług religijnych. Synagoga została zamknięta przez muzułmanów, którzy sprzeciwili się wojnie w Gazie w latach 2008-2009. Jedyna pozostała synagoga znajduje się w mieście Tondano, w północnej części Celebes, w którym przebywa około dziesięciu ortodoksyjnych Żydów (chasydzka grupa judaistyczna Chabad-Labawicz). W Indonezji The United Indonesian Jewish Community - the Association of Indonesian Jews and Hebrew Descendants (UIJC) została utworzona przez społeczność indonezyjską pochodzenia żydowskiego ze wszystkich sekt. Organizacja ta istnieje od 2009 r., ale została zainaugurowana dopiero w październiku 2010 r. UIJC jest prowadzona przez rodzinę Verbrugge’ów. Według źródła z UIJC, obecnie żydowskim pochodzeniem w Indonezji legitymuje się blisko 2 tys. osób, są oni rozmieszczeni niemal równomiernie w całej Indonezji. W 2015 r. pierwsze oficjalne centrum żydowskie rabina Tovii Singera, Beit Torat Chaim w Dżakarcie, zostało zainaugurowane przez Ministerstwo Religii.

\section{Bahaizm}

W 2005 r. w Indonezji było około 22 tys. osób, będących wyznawcami nowej religii bahaizmu. Dokładna liczba tych 
osób nie jest znana, ponieważ często doświadczają oni presji i odrzucenia ze strony otaczającej ich społeczności. Od 2014 r. nastąpiła poprawa w planach rządu dotyczących ewentualnego uznania tej religii (istnieje błędne przekonanie, że oficjalne uznanie bahaizmu nastąpiło w 2014 r.).

\section{Sikhizm}

Migracja Sikhów do Indonezji rozpoczęła się w latach 70. ubiegłego wieku (kustosze i handlarze). Istnieje kilka gurdwarów (miejsc kultu) i szkół na Sumatrze i Jawie, takich jak gurdwara w Medan, która została zbudowana w $1911 \mathrm{r}$. W 2005 r. została założona Indonezyjska Rada Religijna Sikhów (Matasi), licząca około 7 tys. osób (lub 10-15 tys.). Sikhowie nie należą do sześciu uznanych religii w Indonezji, a Sikhowie wypełniają kolumnę religijną na swoich KTP słowem „hinduski”. Oprócz ortodoksyjnych Sikhów w Indonezji, reprezentują oni także reformatorski ruch Sikh Radha Soami Satsang Beas (RSSB).

\section{Dżinizm}

W Dżakarcie istnieje niewielka grupa starożytnej religii dżinizmu - Jain Social Group Indonesia (JSG Indonesia) wśród Hindu-Indonezyjczyków.

\section{Nowe ruchy religijne}

Najbardziej znanymi nowymi ruchami religijnymi w Indonezji są: Stowarzyszenie Teozoficzne, Medytacja Transcendentalna, Falun Gong i pochodzący z Indonezji Subud i Wspólnoty Eden. 


\section{Chrześcijaństwo}

\section{Protestantyzm}

Chrześcijaństwo protestanckie rozwinęło się w Indonezji w holenderskim okresie kolonialnym administrowanym przez Holenderską Kompanię Wschodnioindyjską (niderl. Vereenigde Oostindische Compagnie - VOC) od około XVI w. Polityka VOC, polegająca na reformowaniu katolicyzmu, skutecznie przyczyniła się do zwiększenia liczby protestantów w Indonezji. Religia ta rozwinęła się bardzo szybko w XX w., co naznaczone było przybyciem misjonarzy z Europy do kilku regionów Indonezji, np. do zachodniego regionu Papui i do Małych Wysp Sundajskich (Nusa Tenggara). W 1965 r., kiedy to toczyła się walka o władzę, ludzie bez religii byli uważani za bezbożnych, a zatem nie uzyskali pełnych praw obywatelskich. W związku z tym Kościół protestancki doświadczył rosnącej liczby członków ${ }^{53}$. Protestanci tworzą ważne stowarzyszenie mniejszościowe na kilku obszarach. Na przykład na wyspie Sulawesi, 17\% populacji stanowią protestanci. W Indonezji są trzy prowincje, gdzie większość ludności to protestanci, a mianowicie Papua, Północna Sulawesi i Zachodnia Papua, z odpowiednimi udziałami: $65,48 \%, 63,60 \%$ i 53,77\% całej populacji. W Papui nauki protestanckie były dobrze przyjmowane przez rdzennych mieszkańców. W Ambon protestantyzm odnotował bardzo duży rozwój wraz z islamem. W Północnym Sulawesi, Minahasa, ludność przeszła na protestan-

53 J. Sihar Aritonang, K. Steenbrink, A History of Christianity in Indonesia, Leiden 2008. 
tyzm około XVIII w. Dziś większość mieszkańców plemienia Batak (Toba, Karo, Simalungun, Pakpak i części Angkola) oraz Nias na Sumatrze Północnej wyznaje kilka sekt protestanckich. Ponadto zaczęli przybywać również muzułmańscy transmigranci z Jawy i Madury. Obecnie 6,69\% ludności Indonezji to protestanci. Fellowship of Churches in Indonesia (PGI) jest jedyną organizacją patronacką dla większości Kościołów protestanckich na tym archipelagu.

„Protestanci w Indonezji są rozbici na ponad czterysta niezależnych kościołów, co jest skutkiem liberalnej interpretacji Pisma Świętego. Niektóre z nich liczą tylko kilkuset wiernych. Część działa w ramach Rady Kościołów w Indonezji, inne ugrupowania nie są zrzeszone i niewiele mają wspólnego z głoszeniem Ewangelii. Ruch ekumeniczny jest słaby i właściwie rozwija się jedynie wśród elit. W terenie, pomiędzy wspólnotami poszczególnych wyznań chrześcijańskich, często dochodzi do aktów wrogości i prozelityzmu"54.

\section{Prawosławni chrześcijanie}

W XX w. Wschodnia Cerkiew Prawosławna oficjalnie istniała pod nazwą Indonezyjskiej Cerkwi Prawosławnej (GOI), gdzie kapłani prawosławni w Indonezji pochodzili z dwóch regionów, a mianowicie, pierwotnie z Greckiej Cerkwi Prawosławnej Patriarchy Konstantynopola, a następnie z Rosyjskiej Cerkwi Prawosławnej poza rosyjskim patriarchatem moskiewskim. Generalnym przewodniczącym Indonezyjskiej Cerkwi Prawosławnej jest Daniel Bambang Dwi Byantoro, który jest pierwszym indonezyjskim księdzem prawosławnym w Indonezji. Ponadto w Indonezji istnieje

54 J. Glinka, Sto lat Werbistów w Indonezji, „NURT SVD” 2014, nr 2, s. 190. 
Orientalna Cerkiew Prawosławna, a mianowicie Syryjska Cerkiew Prawosławna i Koptyjska Cerkiew Prawosławna ${ }^{55}$.

\section{Katolicyzm}

W XIV i XV w., czy to jako kontynuacja ludu w Barusie, czy też nie, istniały dowody na to, że na Sumatrze Południowej byli chrześcijanie katoliccy. Chrześcijanie katoliccy pojawili się w Indonezji wraz z przybyciem Portugalczyków, a następnie Hiszpanów, którzy handlowali przyprawami. Portugalczycy probowali szerzyć katolicyzm w Indonezji, począwszy od Moluków w 1534 r. ${ }^{56}$ W latach 1546-1547 wyspę odwiedził pionierski misjonarz chrześcijański, Franciszek Ksawery, który ochrzcił kilka tysięcy miejscowych mieszkańców ${ }^{57}$. W XVI w. Portugalczycy i Hiszpanie zaczęli rozszerzać swoje wpływy w Manado i regionie Minahasa, docierając do Flores i Timoru. Portugalczycy i Hiszpanie odegrali pewną rolę w szerzeniu katolickiego chrześcijaństwa, ale nie trwało to długo, ponieważ holenderskim władzom VOC udało się wyrzucić Hiszpanów i Portugalczyków z Północnego Sulawesi i Moluków. VOC zaczeły przejmować kontrolę nad Północnym Sulawesi, aby chronić swoją pozycję na Molukach. W okresie VOC wielu rzymskokatolickich propagatorów i wyznawców zostało aresztowanych. Holandia była protestanckim państwem bazowym, a katolicy byli uważani za wspólników Hiszpanii i Portugalii, politycznych i ekonomicznych wrogów VOC. Z tego właśnie

55 I. Popov, Buku rujukan semua aliran dan perkumpulan agama di Indonesia, Singaraja 2017.

56 J. Sihar Aritonang, K. Steenbrink (red.), A History of Christianity in Indonesia, Leiden 2008.

57 M.C. Ricklefs, A History of Modern Indonesia Since c. 1300, London 1993, s. 25. 
powodu VOC zaczęło wdrażać politykę, która ograniczała i zabraniała rozprzestrzeniania się katolicyzmu. Najbardziej poszkodowani są katolicy w Północnym Sulawesi, Flores i Timorze. Dziś w Północnym Sulawesi większość stanowią protestanci. Mimo to katolicy nadal stanowią większość we Flores, do tej pory katolicyzm jest religią większościową we wschodniej Nusa Tenggara. Dyskryminacja katolików zakończyła się, gdy Holandia została pokonana przez Francję podczas wojen napoleońskich. W 1806 r. Ludwik Bonaparte, młodszy brat Napoleona I, który był katolikiem, został mianowany królem Holandii. Z jego polecenia katolicyzm mógł swobodnie rozwijać się w holenderskich Indiach Wschodnich ${ }^{58}$. Katolicyzm zaczął się rozwijać na Jawie Środkowej, kiedy Frans van Lith, holenderski jezuita, osiedlił się w Muntilan w 1896 r. i szerzył wiarę katolicką wśród miejscowej ludności. Początkowo jego wysiłki nie przyniosły zadowalających rezultatów, aż do 1904 roku, kiedy to czterech przywódców z okolic Kalibawangu poprosiło go o wyjaśnienie, czym jest katolicyzm. 15 grudnia 1904 r. 178 Jawajczyków zostało ochrzczonych w Semagung, Muntilan, Magelang. W 2006 r. 3\% ludności Indonezji było katolikami, czyli mniej niż protestantów. W większości katolicy mieszkają w Papui i Flores. Oprócz Flores, znaczący obszar katolicyzmu znajduje się na Jawie Środkowej, a mianowicie w okolicach Muntilan, Magelang, Klaten i Yogyakarta. Oprócz społeczeństwa jawajskiego, wiara katolicka rozpowszechniła się także wśród Chińczyków ${ }^{59}$. W Indonezji jest

58 K. Steenbrink, Catholics in Indonesia: A documented history 1808-1942, t. 1: A modest recovery 1808-1903, Leiden 2003; idem, Catholics in Indonesia: A documented history 1808-1942, t. 2: The Spectacular Growth of a Self Confident Minority, 1903-1942, Leiden 2007.

59 Idem, Catholics in Independent Indonesia: 1945-2010, Leiden 2015. 
jedna prowincja, gdzie większość ludności jest katolikami, mianowicie Wschodnie Małe Wyspy Sundajskie (Nusa Tenggara Timur) z 54,14\% udziałem w populacji prowincji.

Katolicyzm, który jest religią mniejszości Indonezyjczyków, wykazuje wiele oznak żywotności. Według Annuarium Statisticum Ecclesiae w 1978 r. istniało w Indonezji 41 parafii obsługiwanych przez księży diecezjalnych, 312 parafii, przez księży zakonnych i 27 parafii bez proboszcza. Liczba księży inkardynowanych do diecezji indonezyjskich kształtowała się na poziomie 136 osób w 1973 roku i 207 w 1978 r. W 1978 r. udzielono chrztu 107102 osobom poniżej 7. roku życia, 44790 - powyżej 7. roku życia (łącznie 151 892). W tym samym roku udzielono 17513 ślubów kościelnych zawartych między katolikami i 7089 - między katolikami i niekatolikami (łącznie 24 602). W 1978 r. liczba katolików (ochrzczeni) kształtowała się na poziomie 3150 tys. osób.

W latach 1978-2017 nastąpił wzrost liczby parafii, duchowieństwa, udzielanych chrztów i małżeństw. W 2017 r. istniało 823 parafii obsługiwanych przez księży diecezjalnych, 511 parafii obsługiwanych przez księży zakonnych i 22 parafie bez stałego duszpasterza. Liczba inkardynowanych księży do diecezji kształtowała się na poziomie 2252 osób. W 2017 r. udzielono 125361 chrztów dzieciom poniżej 7. roku życia i 36738 chrztów dzieciom powyżej 7. roku życia (łącznie - 162 099). Zostało pobłogosławionych w kościele 38457 małżeństw między katolikami i 8914 - między katolikami i niekatolikami (łącznie - 47 371). Kościół katolicki w Indonezji w $2018 \mathrm{r}$. był podzielony na 37 diecezji, z liczbą 8032 tys. katolików w 1450 parafiach.

Szacuje się, że liczba katolików w Indonezji wynosi około 3\%, czyli ponad $7 \mathrm{mln}$. „Statystyki kościelne różnią się od państwowych - zwłaszcza gdy chodzi o chrześcijan. Ko- 
ścioły celowo nie ujawniają swoich danych statystycznych. Powszechnie wiadomo, że dla zachowania tzw. "poprawności politycznej« osoby ochrzczone nie zawsze deklarują swoją przynależność religijną. Tymczasem niepodważalnym faktem jest znaczny przyrost chrześcijan. Przykładowo, na przestrzeni od 1900 do 1978 roku liczba mieszkańców wzrosła o 2,85\%, zaś liczba katolików powiększyła się o 66\%"60. Mimo że katolicy są w mniejszości w Indonezji, ich wpływ na życie publiczne jest zauważalny. „W 1965 roku jeden z wpływowych wtedy polityków w wykładzie o sytuacji politycznej w Indonezji twierdził, że w kraju tym są trzy siły, które się liczą: rząd, wojsko i Kościół katolicki. Kiedy w dyskusji zwrócono mu uwagę, że katolicy tworzą tylko nieznaczną część społeczeństwa, wyjaśnił: »ale tworzą jedność, która z zapadłej wsi sięga aż do Watykanu«"61.

\section{Relacje między religiami}

Chociaż rząd Indonezji uznaje wiele różnych religii, konflikty między religiami są czasami nieuniknione. Suharto wydawał ustawy, które według niektórych były antychińskie. Prezydent Suharto próbował ograniczyć wszystko, co związane z chińską kulturą, w tym nazwy i religię. W latach 1966-1998 Suharto starał się „zdezislamizować” rząd, dając większy odsetek chrześcijan w gabinecie. Jednak na początku lat 90. pojawiły się problemy związane z islamizacją, a wojsko zostało podzielone na dwie grupy - nacjonalistów i muzułmanów. W epoce Suharto kontynuowano program transmigracji w Indonezji, po uruchomieniu go przez rząd holenderskich Indii Wschodnich na początku XIX w. Celem

60 J. Glinka, Sto lat Werbistów w Indonezji, „NURT SVD” 2014, nr 2, S. 190 .

61 Ibidem, s. 192. 
tego programu jest przeniesienie ludzi z gęsto zaludnionych obszarów, takich jak wyspy Java, Bali i Madura, do mniej zaludnionych obszarów, takich jak Ambon, wyspy Sunda i Papua. Polityka ta spotkała się z dużą krytyką, uznawaną za kolonizację przez Jawajczyków i Maduranczykow, która sprowadziła islam na tereny niemuzułmańskie.

Ludność zachodniego regionu Indonezji to w większości muzułmanie, a chrześcijanie stanowią niewielką mniejszość, podczas gdy we wschodnim regionie ludność chrześcijańska jest równa lub nawet większa od ludności muzułmańskiej. Występowały konflikty między religiami i rasami we wschodniej Indonezji, jak zamieszki na Molukach i zamieszki Poso ${ }^{62}$. W latach 2007-2012 miały miejsce ataki sunnitów na meczety i domy szyitów oraz ahmadyjczyków. Aby temu zapobiec w przyszłości w 2011 r. powołano do życia zwłaszcza sunnitów i szyitów Mejlis (MUHSIN). Rząd zamierzał ograniczyć te konflikty i napięcia, proponując współpracę między religiami. Ministerstwo Spraw Zagranicznych wraz z największą organizacją islamską w Indonezji, Nahdlatul Ulama, należącą do International Islamic Scholars, wprowadziło umiarkowane nauki islamskie, które jego zdaniem zmniejszą te napięcia. 6 grudnia 2004 r. odbyła się konferencja międzywyznaniowa pod hasłem „Dialog współpracy międzywyznaniowej” („Dialogue of Interfaith Cooperation"): A Building and Harmony Society. W konferencji uczestniczyły państwa członkowskie ASEAN, Australia, Timor Wschodni, Nowa Zelandia i Papua-Nowa Gwinea,

62 Ch.R. Duncan, Violence and Vengeance: Religious Conflict and Its Aftermath in Eastern Indonesia, London 2013; R. Pringle, Understanding Islam in Indonesia: Politics and Diversity, Singapore 2010, s. 143-157; S.A. Wargacki, Wptywy indonezyjskie na krajowców Irianu Zachodniego, [w:] Ludy i kultury Australii i Oceanii, red. F.M. Rosiński, Wrocław 2001, s. $67-82$. 
co miało na celu omówienie możliwości współpracy między różnymi grupami religijnymi w minimalizowaniu konfliktów między religiami w Indonezji.

Do tolerancji i wzajemnej współpracy różnych religii wzywał papież Paweł VI podczas swojej podróży do Indonezji w 1970 r. W podobnym duchu przemawiał Jan Paweł II w 1989 r.: „Indonezyjscy wyznawcy różnych religii mają do odegrania ważną rolę w ciągłym rozwoju swego narodu, bowiem wiara w Boga i łączące ludy wartości duchowe są potężnymi siłami dobra”. Głównym zadaniem Indonezji jest „zbudowanie harmonijnego społeczeństwa z wielu różnych elementów - źródło dzisiejszej nadziei i przyszłej wielkości narodu". W kraju, w którym islam stał się religijną drogą większości Indonezyjczyków, katolicyzm pełni ważną rolę w społeczeństwie, przynajmniej w niektórych regionach Indonezji.

\section{Religijność Indonezyjczyków w świetle badań socjologicznych}

Indonezję zalicza się do państw należących do tzw. cywilizacji muzułmańskiej, obejmującej Środkowy Wschód, północną Afrykę i częściowo Azję Południowo-Wschodnią (od 71\% do 96\% ludności przynależy do religii muzułmańskiej). Obok Indonezji należą do niej: Algieria, Jordania, Pakistan, Turcja, Azerbejdżan, Bangladesz, Albania, Maroko, Iran i Egipt. Z badań empirycznych zrealizowanych w ponad 100 krajach świata wynikało, że społeczeństwa Zachodu i te żyjące w kulturze muzułmańskiej nie różniły się istotnie pod względem zadowolenia ze sposobu, w jaki demokracja funkcjonuje w praktyce, poparcia dla ideałów demokratycznych i akcep- 
tacji silnego przywództwa. Społeczeństwa muzułmańskie faktycznie wyrażały znacznie większe poparcie dla roli społecznej przywódców religijnych niż społeczeństwa zachodnie. Najbardziej podstawowa linia podziału kulturowego między Zachodem a państwami muzułmańskimi dotyczyła kwestii równouprawnienia płci i liberalizacji podejścia do seksualności ${ }^{63}$.

Filozofia narodowa Indonezji Pancasila (pięć zasad) z pierwszym punktem o istnieniu jedynego Boga obejmuje nie tylko sferę formalnego życia obywatelskiego, lecz można ją również zrozumieć jako filar dla sfer duchowych obywateli, wedle którego lepiej byłoby być religijnym aniżeli niereligijnym. Podkreślić tutaj trzeba, że mieć wpisaną religię w dowodzie osobistym to jedno, a być pobożnym lub religijnym $\mathrm{w}$ ramach danej religii to drugie. Ale jedno i drugie stanowią cel zawartego w Pancasila punktu „wiara w jednego Boga”.

Jak religijni (pobożni, praktykujący) są Indonezyjczycy? Alvara Research Center, indonezyjskie centrum badawcze zajmujące się religiami, przeprowadziło w 2017 r. badanie wśród wyznawców islamu. Uzyskane wyniki możemy uznać za barometr dla całej Indonezji, gdyż islam wyznaje największa liczba obywateli. Indykatorem religijności według tegoż centrum badawczego są osobiste modlitwy, uczestnictwo $\mathrm{w}$ nabożeństwach oraz w organizacjach religijnych ${ }^{64}$. Badanie to wykazało, że ogólnie $95 \%$ badanych uważa religię za ważny element w życiu codziennym. Wśród badanych $41 \%$ przyznaje się do prywatnych modlitw (w islamie pięć razy dziennie),

63 P. Norris, R. Inglechart, Sacrum i profanum. Religie i polityka na świecie, tłum. R. Babińska, Kraków 2006, s. 203-225; J. Dziedzina, Pożegnanie z Allahem?, „Gość Niedzielny” 2020, nr 38, s. 52-54.

64 INDONESIA MOSLEM REPORT 2019: „The Challenges of Indonesia Moderate Moslems”, Dokument Alvara Research Center. 
$22 \%$ - rzadziej się modli prywatnie, a jedynie $0,9 \%$ nigdy tego nie czyni; 26,5\% respondentów uczestniczy w nabożeństwach kilka razy w roku, a 28,8\% - co tydzień. Jedynie 5,0\% nigdy nie chodzi na nabożeństwa. W całej zbiorowości $23,7 \%$ badanych było członkami różnych organizacji religijnych.

Amerykańskie Paw Research Center potwierdza tezę o 95\% uważających religię za bardzo ważną w życiu codziennym $^{65}$. Badając ogólnie religijność na całym świecie potwierdzili znaną już hipotezę, że im lepszy dobrobyt, tym mniejsza jest religijność (pobożność), choć Stany Zjednoczone stanowią tu wyjątek. Indonezja zalicza się według WTO do państw rozwiniętych, więc pojawia się również pytanie o poziom religijności w ramach tejże hipotezy. Dwóch badaczy z wydziału socjologii religii na uniwersytetach Gadjah Mada (UGM) i Muhammadiyah w Jogjakarcie, Zaki Abdullah i Hasse Jubba przeprowadzili w 2019 r. sondaż na temat przestrzegania zasad swoich religii przez Indonezyjczyków. Wśród 32466 badanych osób było: 29208 wyznawców islamu (89,96\%), 417 katolików (1,28\%), 1258 protestantów (3,87\%), 1537 wyznawców hinduizmu (4,73\%) oraz 46 buddystów $(0,14 \%)^{66}$. Z badań tych wynika, że zasady swojej religii przestrzega 75,64\% wśród wyznawców islamu, 78,17\% katolików, 82,75\% protestantów, 93,94\% hinduistów oraz 73,91\% buddystów. W całej

65 https://www.pewresearch.org/global/2008/09/17/chapter-2-religiosity/ [dostęp: 13.10.2020].

66 Pengaruh religiusitas dan kegiatan spiritual terhadap persepsi tingkat keamanan di Indonesia, "Jurnal Studi Agama dan Masyarakat" 2020, vol. 16, nr 01. s. 15, https://www.researchgate.net/ publication/342531653_PENGARUH_RELIGIUSITAS_DAN_KEGIATAN_SPIRITUAL_TERHADAP_PERSEPSI_TINGKAT_KEAMANAN_DI_INDONESIA/fulltext/5efa485692851c52d6073398/ PENGARUH-RELIGIUSITAS-DAN-KEGIATAN-SPIRITUAL-TERHADAP-PERSEPSI-TINGKAT-KEAMANAN-DI-INDONESIA.pdf [dostęp: 13.10.2020]. 
zbadanej zbiorowości było 80,88\% obywateli wiernie praktykujących swoje religie. Można zatem wnioskować, że pomimo statusu rozwiniętego ekonomicznie kraju, Indonezyjczycy nadal są bardzo religijni.

Pozostaje otwartym pytanie, skąd ta religijność lub dlaczego religia jest tak ważna dla Indonezyjczyków, oprócz odgórnego założenia zawartego w Pancasila i Konstytucjach Narodowych (UUD 1945)? Odpowiedzi na to pytanie można poszukiwać w naturze Indonezyjczyków. Już po przodkach odziedziczyli pewne niekonwencjonalne podejście do sfery sacrum. Sfera ta obejmowała całokształt życia codziennego, ale i życie po życiu. Sfera duchowości stoi ponad wszystko i stanowi najwyższy autorytet w systemie obyczajowym adat ${ }^{67}$. Ta świadomość, która jest wiernie przekazywana przez pokolenia została przez ojców narodów skrystalizowana i zaanektowana do Konstytucji narodu przy powstawaniu Indonezji jako państwa niepodległego. Religia istnieje dziś zatem w każdej dziedzinie życia obywatelskiego. Indonezja jako jeden z niewielu państw posiadających Ministerstwo Religii, które zarządza nie tylko współżyciem międzyreligijnym, ale również ma jako zadanie dbanie o rozwój wychowania duchowego obywateli68.

\section{Uwagi końcowe}

Teorię sekularyzacji należy udoskonalać, ale nie należy jej odrzucać, przede wszystkim weryfikować w różnych kon-

67 M. Erb, The Manggaraians. A Guide to Traditional Lifestyles, Singapur 1999, s. 28 i n. Zob. także: Koentjaranigrat, Anthropology in Indonesia, „A Bibliographical Review” 1975, s. 62.

68 M. Seo, State Management of Religion in Indonesia, Oxon 2013, s. 45 . 
tekstach społeczno-kulturowych. Przypadek Indonezji pokazuje, że religia istnieje jako część integralna nowoczesnych czy modernizujących się społeczeństw. Do sytuacji w tym kraju nie pasują teorie socjologiczne sekularyzacji, które powstały w kontekście europejskim, co najmniej wymagają one znacznej modyfikacji. W ostatnich latach sytuacja religijna w Indonezji ulega powolnym zmianom. Zmiany w religijności współczesnej w tym kraju wskazują na bardziej złożone kształty i mechanizmy jej przekształceń w społeczeństwie, niż wyznaczały to teorie sekularystyczne. W wielu państwach pozaeuropejskich tradycyjne formy religijności są w dalszym ciągu upowszechnione, mimo rozwoju procesów modernizacyjnych. To wszystko daje podstawy do zwątpienia w prawomocność tezy o niepołączalności modernizacji i religijności oraz postawienia pytania czy europejska sekularyzacja związana z modernizacją społeczną jest tylko wyjątkiem a nie modelem, według którego przebiegają procesy przemian religijności.

Część socjologów podtrzymuje tezę, że procesy modernizacji społecznej wywierają raczej negatywny wpływ na pole religijności, nawet jeżeli w pewnych okolicznościach modernizacja i religijność mogą być kompatybilne. Słowo „raczej” wskazuje, że ten wpływ nie musi być wyraźny i niepodważalny we wszystkich państwach, regionach czy w dziedzinach życia religijnego. Jeżeli nawet postępująca sekularyzacja - chociaż zróżnicowana w poszczególnych państwach europejskich - jest niezaprzeczalnym faktem, a większość Europejczyków zrezygnowała z regularnie odbywanych tradycyjnych praktyk religijnych, to prywatna i indywidualna wiara wciąż jest dość upowszechniona w Europie. Standardowe wyjaśnienia zmian w religijności ogólnymi procesami modernizacyjnymi nie są do końca 
przekonujące, bowiem podobne procesy modernizacyjne w innych częściach świata nie prowadzą do takiej sekularyzacji ${ }^{69}$. Modernizacja społeczna może wzmacniać albo osłabiać pozycję religii i Kościołów w społeczeństwie, zależy to od wielu kontekstów społeczno-kulturowych.

\title{
Bibliografia
}

\begin{abstract}
Abstrakt
W niniejszym artykule określamy najpierw czym jest modernizacja społeczna, następnie omawiamy relacje modernizacji społecznej i religii, w końcu przedstawiamy szerzej historię religii w Indonezji oraz religijność Indonezyjczyków w świetle sondaży opinii publicznej i badań socjologicznych. Indonezja jest państwem zróżnicowanym etnicznie, kulturowo, językowo i pod względem religijnym. Zdecydowaną większość mieszkańców w Indonezji stanowią muzułmanie (około 19\%), katolików jest około 3\%. Modernizacja społeczna nie prowadzi w Indonezji do coraz bardziej skutecznego usuwania religii z przestrzeni publicznej. Do sytuacji w Indonezji nie pasują teorie socjologiczne, które powstały w europejskim kontekście kulturowym lub co najmniej wymagają one znacznej modyfikacji. Religia była i jest jednym z najważniejszych filarów życia publicznego.
\end{abstract}

Keywords: modernizacja społeczna, religia i religijność, sekularyzacja, islam, chrześcijaństwo, Indonezja.

\begin{abstract}
In this article we first define what social modernization is, then we discuss the relationship between social modernization and religion, and finally we present the history of religion in Indonesia and the

69 J. Casanova, Kosmopolitismus, der Kampf der Kulturen und multiple Modernen, [w:] Im Dialog. Systematische Theologie und Religionssoziologie, red. A. Kreutzer, Fr. Gruber, Freiburg im Breisgau 2013, s. $162-186$.
\end{abstract}


religiosity of the Indonesian people in the light of opinion polls and sociological research. Indonesia is a country of ethnic, cultural, linguistic and religious diversity. The vast majority of the inhabitants of Indonesia are Muslims (about 87.18\%), Catholics are about 3\%. Social modernization in Indonesia does not lead to an increasingly effective removal of religion from public space. Sociological theories that were conceived in the European cultural context, do not apply to the situation in Indonesia, or at least require significant modification. Religion had been and still is one of the most important pillars of public life.

Keywords: social modernization, religion and religiosity, secularization, Islam, Indonesia. 


\section{Kamila Rezmer-Płotka}

Uniwersytet Mikolaja Kopernika w Toruniu

ORCID ID: https: / / orcid.org/0000-0002-1458-5076

\section{Naruszanie wolności religijnej w kontekście demokracji opancerzonej: studium przypadku Indii $^{1}$}

\section{Wprowadzenie}

Indie ze względu na bardzo duże zaludnienie uznawane są za największą demokrację świata ${ }^{2}$. To również państwo formalnie świeckie. Jednak, jak pokazuje raport z 2020 r. przygotowany przez amerykańską Komisję ds. Międzynarodowej Wolności Religijnej (USCIFR), w Indiach za rządów premiera Narendry Modiego systematycznie ogranicza się wolność religijną mniejszości religijnych, a także dochodzi do prób stworzenia państwa wyznaniowego (tylko dla wyznających hinduizm) ${ }^{3}$. W kolejnym raporcie z $2021 \mathrm{r}$. ponownie wskazywano na niepokojące działania podejmowane przeciwko wyznającym inne religie, m.in. wykorzystywanie mediów społecznościowych czy innych kanałów komunikacji do szerzenia dezinformacji i nienawiści odnoszącej się do mniejszości takich jak muzułmanie, chrześcijanie

1 Artykuł stanowi efekt realizacji projektu badawczego pt. „Kontestacja polityczna a nowa demokracja opancerzona” finansowanego przez Narodowe Centrum Nauki. Numer rejestracyjny grantu 2018/31/B/HS5/01410.

2 European Parlament, India: the biggest democracy in the world, https://www.europarl.europa.eu/RegData/etudes/ATAG/2014/538956/ EPRS_ATA(2014)538956_REV1_EN.pdf [dostęp: 20.06.2020].

3 United States Commission on International Religious Freedom, $A n$ nual Report 2020, https://www.uscirf.gov/sites/default/files/USCIRF\%20 2020\%20Annual\%20Report_Final_42920.pdf [dostęp: 20.06.2020]. 
czy dalici ${ }^{4}$. Wolność religijna, oprócz tego, że stanowi jedno z podstawowych praw człowieka, może również stanowić jeden ze wskaźników wskazujących na występowanie w danym państwie procesu opancerzania się demokracji.

Obecnie ma miejsce pandemia koronawirusa, za sprawą, której obserwuje się przyspieszenie tychże procesów, chociażby w państwach członkowskich Unii Europejskiej ${ }^{5}$. Wprowadzane w wielu obszarach ograniczenia mogą stanowić zarówno sposób na przeciwdziałanie rozprzestrzenianiu się wirusa, jak i decyzje czysto polityczne bądź mające na celu realizowanie zgoła odmiennych interesów. Jednak rozstrzygnięcie, które z działań były podejmowane ze względów bezpieczeństwa, a które z innych powodów będzie możliwe dopiero z perspektywy czasu. Z tego powodu w niniejszym artykule odniesiono się do ograniczeń wskazywanych w 2019 r., zanim wystąpiła pandemia koronawirusa.

\section{Ramy teoretyczne i metodologia}

Kategoria demokracji opancerzonej po raz pierwszy była zastosowana przez Karla Lowensteina w odniesieniu do Republiki Weimarskiej ${ }^{6}$ i pierwotnie odnosiła się do reżimu politycznego, w którym parlament ${ }^{7}$ i sądownictwo wyposażone

4 United States Commission on International Religious Freedom, Annual Report 2021, https://www.uscirf.gov/sites/default/files/202104/2021\%20Annual\%20Report_0.pdf [dostęp: 28.04.2021].

5 K. Rezmer-Płotka, The Effects of Crises in the European Union as a Manifestation of the Militant Democracy Rule Implementation, „Przegląd Prawa Konstytucyjnego" 2020, nr 6 (58), s. 615-621.

6 K. Loewenstein, Militant Democracy and Fundamental Rights I, „The American Political Science Review” 1937a, nr 3 (31), s. 417-432; K. Loewenstein, Militant Democracy and Fundamental Rights II, „The American Political Science Review" 1937b, nr 4 (31), s. 638-658.

7 J. Marszałek-Kawa, The Institutional Position and Functions of the 
są w środki prawne umożliwiające ograniczanie indywidualnych wolności demokratycznych celem obrony demokracji przed tymi, których uznaje się za jej wrogów ${ }^{8}$. Pomimo że sytuacja społeczno-polityczna od tamtej pory uległa wielu zmianom, to proces opancerzania się demokracji jest nadal obserwowany. Pośród wskaźników, które pozwalają analizować współczesne demokracje pod kątem występowania cech charakterystycznych dla demokracji opancerzonych można wskazać m.in. wolność religijną ${ }^{9}$. Zakłada się, że wolność religijna lub przekonań obejmuje:

1. wolność przyjęcia, zmiany lub wyrzeczenia się religii lub przekonań (V1);

2. wolność od przymusu (V2);

3. prawo do uzewnętrzniania religii lub przekonań, a w ramach tej sekcji wskazuje się na:

- wolność kultu (V3a),

- miejsca kultu (V3b),

- symbole religijne (V3c),

- przestrzeganie świąt i dni wolnych (V3d),

- powoływanie duchowieństwa (V3e),

- nauczanie i rozpowszechnianie materiałów (w tym działalność misyjna) (V3f),

Sejm of the Republic of Poland after the Accession to the European Union, Odessa 2019.

8 K. Loewenstein, Militant Democracy and Fundamental Rights, op.cit., s. 418; G. Molier, R.B. Rijpkema, Germany's New Militant Democracy Regime: National Democratic Party II and the German Federal Constitutional Courts's 'Potentiality' Criterion for Party Bans: Bundesverfassungsgericht, Hudgment of 17 January 2017, 2 BvB 1/13, National Democratic Party II, „European Constitutional Law Review” 2018, nr 2 (14), s. 394-409.

9 J.-W. Müller, Militant Democracy, [w:] The Oxford Handbook of Comparative Constitutional Law, red. M. Rosenfeld, András Sajó, New York 2012, s. 1119. 
- prawo rodziców do zapewnienia swoim dzieciom edukacji religijnej i moralnej (V3g),

- rejestrację (V3h),

- komunikowanie się z osobami i wspólnotami w sprawach religijnych na poziomie krajowym i międzynarodowym (V3i),

- zakładanie i utrzymywanie instytucji charytatywnych i humanitarnych/zabieganie o fundusze i otrzymywanie ich (V3j),

- sprzeciw sumienia $(\mathrm{V} 3 \mathrm{k})^{10}$.

Analizie poddano raport organizacji U.S. Department of State z 2019 r., czyli tuż przed wystąpieniem kryzysu, jakim jest pandemia koronawirusa, a konkretnie sekcja druga zatytułowana „Status of Government Respect for Religious Freedom", która odnosi się bezpośrednio do działań podejmowanych przez rząd. Za narzędzie badawcze posłużyły natomiast wymienione wyżej elementy składające się na wolność religijną lub przekonań. Pozwoliło to udzielić odpowiedzi na pytanie badawcze brzmiące następująco: w jaki sposób naruszano wolność religijną tuż przed wystąpieniem kryzysu? W analizie skupiono się wyłącznie na przypadkach naruszania wolności religijnej, wyłączono natomiast działania podejmowane na rzecz jej ochrony bądź zaniechanie działania. To celowy zabieg pozwalający na określenie, z jakiego powodu Indie wskazywane są jako jedno z państw naruszających wolność religijną w największym stopniu.

10 Rapporteur's Digest on Freedom of Religion by Belief. Excerpts of the Reports from 1986 to 2011 by the Special Rapporteur on Freedom of Religion or Belief Arranged by Topics of the Framework for Communications, https://www.ohchr.org/Documents/Issues/Religion/RapporteursDigestFreedomReligionBelief.pdf [dostęp: 20.06.2020]. 


\section{Naruszenia wolności religijnej w Indiach (2019)}

W styczniu ${ }^{11}$ przerwano nabożeństwo w Uttar Pradesh, aresztowano kilka osób, a także według relacji organizacji pozarządowej i mediów doszło do pobicia przez policję pastora. Zakwalifikować to można przede wszystkim do naruszenia wolności kultu (V3a) i miejsca kultu (V3b).

W kwietniu ${ }^{12}$ doszło do ataku w jednym z kościołów w dystrykcie Jaunpur w stanie Uttar Pradesh, jednak policja, która była tego świadkiem nie interweniowała. Można to zaliczyć do naruszeń wolności kultu (V3a) oraz miejsca kultu (V3b). W kwietniu doszło również do zatrzymania grupy chrześcijańskiej na podstawie zgłoszenia przez hinduską grupę nacjonalistyczną, co również można zakwalifikować jako naruszenie wolności i miejsca kultu.

Od maja ${ }^{13}$ wskazywano, że wiele osób zginęło lub zostało rannych w wyniku przemocy ze strony tłumu, np. bito i zmuszano wyznawców innych religii do intonowania hinduskich wezwań. Wskazano, że w związku z tym policja nie przeprowadziła właściwych śledztw, a ponadto wszczynała postępowania karne przeciwko świadkom, co miało na celu ich zastraszenie. W tym przypadku naruszania wystąpiły na poziomie wolności przyjęcia, zmiany lub wyrzeczenia się religii lub przekonań (V1) oraz wolności od przymusu (V2). W tabeli nr 1 oznaczono wystąpienie ograniczeń na tym poziomie wyłącznie w maju, ponieważ trudno określić do jakiego czasu

11 U.S. Department of State, 2019 Report on International Religious Freedom: India, https://www.state.gov/reports/2019-report-on-international-religious-freedom/india/ [dostęp: 25.06.2020].

12 Ibidem.

13 Ibidem. 
prowadzono tę statystkę. Z dużym prawdopodobieństwem można jednak przypuszczać, że działania te miały miejsce aż do grudnia. Ze względu na brakującą informację nie oznaczono ich jednak w innych miesiącach. W maju również doszło do zatrzymań na podstawie zarzutów dotyczących przymusowych konwersji (V2).

W czerwcu ${ }^{14}$ doszło do zatrzymania chrześcijan za organizowanie spotkań modlitewnych z zarzutem „przymusowego nawracania", jednak tego samego dnia zostali wypuszczeni. Naruszono jednak wolność kultu (V3a). To nie jedyny przypadek zatrzymań za przymusową konwersję.

Od lipca ${ }^{15}$ do końca roku wycofano zarzuty i uniewinniono dużą liczbę oskarżonych o ataki na muzułmanów. Trudno jednoznacznie zakwalifikować te działania, ale prawdopodobnie można je rozpatrywać we wszystkich trzech głównych kategoriach, tj. wolności przyjęcia, zmiany lub wyrzeczenia się religii lub przekonań (V1), wolności od przymusu (V2) oraz ogólnie pojętego prawa do uzewnętrzniania religii lub przekonań (V3 - wszystkie kategorie), ponieważ ewidentnie dotyczyło to określonej grupy wyznawców. Sprawy i ataki dotyczyły różnej materii, dlatego można je zakwalifikować do wszystkich elementów składających się na wolność religijną.

W sierpniu ${ }^{16}$ cofnięto półautonomiczny status Dżammu i Kaszmiru, państwa z większością muzułmańską. Następnie podzielono go na dwa terytoria związkowe. Od sierpnia do grudnia rząd zamknął także na nowych terytoriach większość meczetów. Te działania można zakwalifikować przede wszystkim jako naruszanie wolności kultu (V3a)

$\begin{array}{cl}14 & \text { Ibidem. } \\ 15 & \text { Ibidem. } \\ 16 & \text { Ibidem. }\end{array}$ 
i miejsca kultu (V3b). W międzyczasie rząd i minister spraw wewnętrznych informowali, że protesty, które miały miejsce w związku z tymi działaniami, przerodziły się w akty terroryzmu i zapewniano, że nikt nie zginął z rąk policji. W sierpniu doszło również do zburzenia hinduskiej świątyni w związku $\mathrm{z}$ nielegalnym jej zbudowaniem na terenie będącym własnością rządu. W związku z tym, że w tym przypadku dochodzi czynnik nielegalnego zbudowania budynku sakralnego, nie zakwalifikowano go więc jako naruszenia miejsca kultu. Również w sierpniu pojawił się pomysł, aby usunąć ze stanowisk niehinduistycznych pracowników pracujących w zarządzie świątyń hinduistycznych. Chodziło o to, aby niehinduscy pracownicy nie ukrywali swoich przekonań religijnych, a w razie potrzeby by możliwe było przeprowadzenie inspekcji mieszkań w celu ustalenia ich przynależności religijnej. Ostatecznie jednak nikt nie stracił pracy.

We wrześniu ${ }^{17}$ główny minister Uttar Pradesh, czyli Yogi Adityanath podczas jednego z wywiadów użył obraźliwego terminu w stosunku do muzułmańskich mężczyzn, który miał wskazywać na ich wysiłki w celu związania się z hinduskimi kobietami i zmuszania ich do przejścia na islam. Wypowiedź po pierwsze można potraktować jako dyskryminującą, a po drugie można ją zakwalifikować jako wolność od przymusu (V2), która miała być łamana przez wyznawców islamu. Jak również w tym przypadku można odnieść to do wolności przyjęcia, zmiany lub wyrzeczenia się religii lub przekonań (V1). W wrześniu aresztowano również katolickiego księdza i świecką przywódczynię za próby nawracania mieszkańców oraz o rzekome nakłanianie do oddania ziemi kościołowi. Jednak jeszcze tego samego miesiąca zwolniono

17 Ibidem. 
ich za kaucją. Także we wrześniu nacjonalistyczna organizacja hinduska Vishwa Hindu Parishad przerwała chrześcijańskie spotkanie modlitewne.

W listopadzie ${ }^{18}$ dochodziło do napięć w związku z przyznaniem przez Sąd Najwyższy pozwolenie na budowę świątyni przez hinduskie organizacje. Muzułmanom zaś przyznał zezwolenie na budowę, ale w innym miejscu. Można to zakwalifikować do naruszeń dotyczących miejsca kultu (V3b).

W grudniu ${ }^{19}$ uchwalono ustawę o zmianie obywatelstwa (CAA), która zmieniła poprzednią z 1995 r., po raz pierwszy w historii kryterium obywatelstwa stała się religia. Doprowadziło to zresztą do licznych protestów i krytyką tych przepisów, które były niezgodne z Konstytucją, ponieważ naruszało status państwa świeckiego. Oprócz naruszenia wolności religijnej w zakresie przede wszystkim wolności przyjęcia, zmiany lub wyrzeczenia się religii lub przekonań (V1). W przypadku protestów wystąpiły również inne wskaźniki właściwe dla demokracji opancerzonych, tj. nadmierne użycie siły przez policję wobec protestujących, ograniczono wolność zgromadzeń publicznych, wprowadzono godzinę policyjną i ograniczono dostęp do Internetu oraz zatrzymano wielu protestujących. W przypadku nowego ustawodawstwa obawiano się również ograniczenia praw wyborczych muzułmanów zamieszkujących Indie (ograniczenie prawa czynnego i biernego to kolejny wskaźnik opancerzania się demokracji). W grudniu dochodziło również do szerzenia mowy nienawiści przez urzędników publicznych oraz stwierdzenia przez premiera, że możliwe jest rozpoznanie kto szerzy nienawiść po stroju w jaki jest ubrany (media

18 Ibidem.

19 Ibidem. 
sugerowały, że chodzi o muzułmanów jako osoby odpowiedzialne za stosowanie przemocy). W tym przypadku należałoby poza mową nienawiści, zakwalifikować tą wypowiedź jako naruszenie z zakresu symboli religijnych (V3c).

Ponadto, bez podania konkretnych dat, miesięcy wskazywano, że w Indiach w 2019 r. dochodziło do grożenia przez policję, naruszania porządku nabożeństw, zatrzymywania np. chrześcijan za niedawanie pieniędzy na ceremonie hinduskie. Wielokrotnie na przestrzeni miesięcy dochodziło również do aresztowań za przymusowe konwersje. Wielokrotnie zarzuty były jednak wycofywane. Nie wskazano również konkretnej daty, ale według źródeł organizacji pozarządowych w Indiach miała również miejsce odmowa wjazdu trzem obywatelom USA do kraju, z obawy, że będą oni zaangażowani w działalność misyjną, co można byłoby zakwalifikować jako nauczanie i rozpowszechnianie materiałów, w tym działalność misyjna (V3f). Wskazano wyłącznie na przypadek, kiedy w sierpniu odmówiono przedłużenia wizy 86-letniej hiszpańskiej pielęgniarce misyjnej (V3f). Pominięto również kontrowersyjne wypowiedzi np. zapowiadające utworzenie straży obywatelskiej mającej rozprawiać się ze zdrajcami i stworzenie hinduskiej Rasztry. Warto wspomnieć, że w 2019 r. 49 celebrytów i działaczy napisało do premiera Modiego list z prośbą o interwencję i powstrzymanie ulegających nasileniu ataków na mniejszości, nadużywania religii oraz rozprzestrzeniania się nietolerancji w państwie. Należy również podkreślić, że miesiące, których nie opisano nie stanowią dowodu na brak występowania naruszeń wolności religijnej, a świadczą jedynie o tym, że dany miesiąc nie był wymieniony w raporcie. Jednak, jak już wskazywano, niektóre z naruszeń nie były określone w czasie. Gdyby wziąć pod uwagę również wypo- 
wiedzi czołowych polityków to z dużym prawdopodobieństwem naruszenia miałyby większą częstotliwość. Nie bez znaczenia pozostaje fakt, że Indie cały czas utrzymują się w czołówce państw naruszających wolność religijną. Analiza wskazuje również, że na podstawie raportu były one szczególnie intensywne od lipca do grudnia 2019 r.

Tabela 1. Naruszanie wolności religijnej w Indiach

\begin{tabular}{|c|c|c|c|c|c|c|c|c|c|c|c|c|}
\hline $\begin{array}{l}\text { Miesiąc/elementy wolności } \\
\text { religijnej lub przekonania }\end{array}$ & 01 & 02 & 03 & 04 & 05 & 06 & 07 & 08 & 09 & 10 & 11 & 12 \\
\hline V1 & & & & & $X$ & & $X$ & $\mathrm{X}$ & $\mathrm{X}$ & $\mathrm{X}$ & $X$ & $X$ \\
\hline V2 & & & & & $\mathrm{X}$ & & $\mathrm{X}$ & $\mathrm{X}$ & $\mathrm{X}$ & $\mathrm{X}$ & $X$ & $\mathrm{X}$ \\
\hline V3a & $\mathrm{X}$ & & & $\mathrm{X}$ & & $X$ & $X$ & $\mathrm{X}$ & $\mathrm{X}$ & $\mathrm{X}$ & $\mathrm{X}$ & $X$ \\
\hline V3b & $\mathrm{X}$ & & & $\mathrm{X}$ & & & $\mathrm{X}$ & $\mathrm{X}$ & $\mathrm{X}$ & $\mathrm{X}$ & $\mathrm{X}$ & $\mathrm{X}$ \\
\hline V3c & & & & & & & $\mathrm{X}$ & $\mathrm{X}$ & $\mathrm{X}$ & $\mathrm{X}$ & $\mathrm{X}$ & $\mathrm{X}$ \\
\hline V3d & & & & & & & $\mathrm{X}$ & $\mathrm{X}$ & $\mathrm{X}$ & $\mathrm{X}$ & $\mathrm{X}$ & $\mathrm{X}$ \\
\hline V3e & & & & & & & $\mathrm{X}$ & $\mathrm{X}$ & $\mathrm{X}$ & $\mathrm{X}$ & $\mathrm{X}$ & $\mathrm{x}$ \\
\hline V3f & & & & & & & $\mathrm{X}$ & $\mathrm{X}$ & $\mathrm{X}$ & $\mathrm{X}$ & $\mathrm{X}$ & $\mathrm{X}$ \\
\hline V3g & & & & & & & $\mathrm{X}$ & $\mathrm{X}$ & $\mathrm{X}$ & $\mathrm{X}$ & $\mathrm{X}$ & $\mathrm{X}$ \\
\hline V3h & & & & & & & $\mathrm{X}$ & $\mathrm{X}$ & $\mathrm{X}$ & $\mathrm{X}$ & $\mathrm{X}$ & $\mathrm{X}$ \\
\hline V3i & & & & & & & $\mathrm{X}$ & $\mathrm{X}$ & $\mathrm{X}$ & $\mathrm{X}$ & $\mathrm{X}$ & $\mathrm{X}$ \\
\hline V3j & & & & & & & $\mathrm{X}$ & $\mathrm{X}$ & $\mathrm{X}$ & $\mathrm{X}$ & $\mathrm{X}$ & $\mathrm{X}$ \\
\hline V3k & & & & & & & $\mathrm{X}$ & $\mathrm{X}$ & $\mathrm{X}$ & $\mathrm{X}$ & $\mathrm{X}$ & $\mathrm{X}$ \\
\hline
\end{tabular}

Źródło: opracowanie na podstawie: 2019 Report on International Religious Freedom: India, https://www.state.gov/reports/ 2019-report-on-international-religious-freedom/india/ [dostęp: 25.06.2020].

\section{Podsumowanie}

W Indiach w 2019 r. dochodziło do regularnego naruszania wolności religijnej, co może świadczyć o procesie opancerzania demokracji, ale nie musi. Oznacza to tylko, że w ba- 
danym okresie wystąpił jeden ze wskaźników wskazujących na proces opancerzania się demokracji. By móc mówić o tym procesie, należałoby analizowany przypadek zbadać pod kątem wszystkich wskaźników, które wyróżnia się jako właściwe dla demokracji opancerzonej lub raczej nowej demokracji opancerzonej. Obecnie, ze względu na inną sytuację społeczno-polityczną, mówi się raczej o nowej demokracji opancerzonej. W ten sposób eliminuje się wskaźniki, które uległy dezaktualizacji od momentu zastosowania tej kategorii po raz pierwszy przez Karla Loewensteina. Ponadto uwzględnia się cechy istotne dla procesów, które miały miejsce po 2008 r., czyli po kryzysie finansowym, który zapoczątkował przyjmowanie przez państwa środków i rozwiązań niedemokratycznych ${ }^{20}$. Argumentem przemawiającym za przyjęciem tej kategorii jest również to, że obecne zagrożenia, przed jakimi stoją systemy demokratyczne, różnią się od tych, które były zakorzenione w ideologiach faszystowskich czy komunistycznych ${ }^{21}$. Na podstawie analizowanego raportu dotyczącego respektowania wolności religijnej w Indiach w 2019 r. można wskazać, że naruszenia wolności religijnej pojawiały się na każdym z trzech głównych poziomów, tj.: wolność przyjęcia, zmiany lub wyrzeczenia się religii lub przekonań (V1); wolność od przymusu (V2); prawo do uzewnętrzniania religii lub przekonań (V3).

20 Zob. J. Rak, Conceptualizing the Theoretical Category of Neo-militant Democracy: The Case of Hungary, „Polish Political Science Yearbook” 2020, nr 2 (49).

21 P. Osiewicz, M. Skrzypek, Is Spain becoming a militant democracy? Empirical evidence from Freedom House Reports, „Aportes Revista De Historia Contemporánea” 2020, nr 103 (35), s. 15. 


\section{Bibliografia}

European Parlament, India: the biggest democracy in the world, https://www.europarl.europa.eu/RegData/etudes/ ATAG/2014/538956/EPRS_ATA(2014)538956_REV1_ EN.pdf.

Loewenstein K., Militant Democracy and Fundamental Rights I, „The American Political Science Review” 1937a, nr 3 (31).

Loewenstein K., Militant Democracy and Fundamental Rights II, „The American Political Science Review” 1937b, nr 4 (31).

Marszałek-Kawa J., The Institutional Position and Functions of the Sejm of the Republic of Poland after the Accession to the European Union, Odessa 2019.

Molier G., Rijpkema R.B., Germany's New Militant Democracy Regime: National Democratic Party II and the German Federal Constitutional Courts's 'Potentiality' Criterion for Party Bans: Bundesverfassungsgericht, Hudgment of 17 January 2017, 2 BvB 1/13, National Democratic Party II, „European Constitutional Law Review” 2018, nr 2 (14).

Müller J.-W., Militant Democracy, [w:] The Oxford Handbook of Comparative Constitutional Law, red. M. Rosenfeld, A. Sajó, New York 2012.

Osiewicz P., Skrzypek M., Is Spain becoming a militant democracy? Empirical evidence from Freedom House Reports, "Aportes Revista De Historia Contemporánea” 2020, nr 103 (35).

Rak J., Conceptualizing the Theoretical Category of Neo-militant Democracy: The Case of Hungary, „Polish Political Science Yearbook" 2020, nr 2 (49).

Rapporteur's Digest on Freedom of Religion by Belief. Ex- 
cerpts of the Reports from 1986 to 2011 by the Special Rapporteur on Freedom of Religion or Belief Arranged by Topics of the Framework for Communications, https:// www.ohchr.org/Documents/Issues/Religion/RapporteursDigestFreedomReligionBelief.pdf.

Rezmer-Płotka K., The Effects of Crises in the European Union as a Manifestation of the Militant Democracy Rule Implementation, „Przegląd Prawa Konstytucyjnego” 2020, nr 6 (58).

United States Commission on International Religious Freedom, Annual Report 2020, https://www.uscirf.gov/sites/ default/files/USCIRF\%202020\%20Annual\%20Report_Final_42920.pdf.

United States Commission on International Religious Freedom, Annual Report 2021, https://www.uscirf.gov/sites/ default/files/2021-04/2021\%20Annual\%20Report_0.pdf. U.S. Department of State, 2019 Report on International Religious Freedom: India, https://www.state.gov/reports/ 2019-report-on-international-religious-freedom/india/.

\section{Abstrakt}

Indie, ze względu na duże zaludnienie, uznawane są za największą demokrację świata. Formalnie są państwem świeckim, jednak w raportach amerykańskiej Komisji ds. Międzynarodowej Wolności Religijnej (USCIFR) pojawiają się jako jedno z państw, gdzie nagminnie ograniczana i łamana jest wolność religijna. Z tego powodu w artykule podjęto się analizy raportu tej organizacji z 2019 r., czyli przed wystąpieniem pandemii koronawirusa, w celu udzielenia odpowiedzi na pytanie badawcze: w jaki sposób naruszano wolność religijną tuż przed wystąpieniem kryzysu? Kategorią zastosowaną w badaniu jest demokracja opancerzona, ponieważ ograniczanie wolności religijnej stanowi jeden ze wskaźników mogących świadczyć o występowaniu 
w danym państwie procesu opancerzania się demokracji. Konkluzje: w badanym okresie wolność religijna była naruszana na każdym z trzech głównych poziomów, tj.: wolności przyjęcia, zmiany lub wyrzeczenia się religii lub przekonań oraz wolności od przymusu i prawa do uzewnętrzniania religii lub przekonań.

Słowa kluczowe: demokracja opancerzona, Indie, wolność religijna, U.S. Department of State

\begin{abstract}
India is considered the world's largest democracy due to its large population. Formally, it is a secular state but in the reports of the US Commission for International Religious Freedom (USCIFR) it appears as one of the countries in which religious freedom is constantly limited and violated. For this reason, the article analyzes the report of this organization for 2019 - before the coronavirus pandemic to answer a research question: how was religious freedom violated before the coronacrisis? The category used in the study is militant democracy, as the restriction of religious freedom is one of the indicators of a process of becoming militant democracy by a given country. Conclusion: in the analyzed period, religious freedom was violated on each of three main levels, i.e. freedom to accept, change or renounce religion or beliefs, freedom from coercion, and the right to manifest religion or beliefs.
\end{abstract}

Keywords: militant democracy, India, religious freedom, US Department of State 


\section{Zbigniew Wiktor}

Uniwersytet Wroclawski

\section{Dorota Jarema}

Uniwersytet Wroclawski

ORCID ID: https://orcid.org/0000-0001-8381-4955

\section{Kontrowersje ideowo-polityczne w kwestii chińskiej drogi do socjalizmu}

\section{Chińska droga do socjalizmu jako przedmiot krytyki}

Socjalistyczna gospodarka rynkowa lub szerzej chińska droga do socjalizmu jest przedmiotem głębokiej kontrowersji ideowej, politycznej i gospodarczej nie tylko w samych Chinach, szczególnie w gremiach kierowniczych KPCh, także w międzynarodowym ruchu robotniczym i komunistycznym. Z jednej strony jest ona postrzegana jako nowatorskie rozwinięcie marksizmu, które ma zastosowanie w państwie o słabym rozwoju gospodarczym, w tym w szczególności przemysłu oraz z licznymi pozostałościami struktur i stosunków przedkapitalistycznych formacji społecznych. $\mathrm{Z}$ drugiej strony formułowane są krytyczne opinie i oceny, zarzucające Deng Xiaopingowi, jego reformom i kontynuatorom odejście od podstawowych zasad i wartości marksizmu i naukowego socjalizmu oraz przejście na stronę kontrrewolucji, zdradę sprawy socjalizmu i pokojową restaurację kapitalizmu. Kwestia ta jest żywo dyskutowana nie tylko w Chinach, także w poszczególnych partiach komunistycznych i na różnych konferencjach międzynarodowego 
ruchu komunistycznego i dzieli ten ruch na stronnictwo pro- i antychińskie w rozumieniu partyjno-ideologicznym i politycznym.

Kwestia jest bardzo złożona w wielu płaszczyznach. Po pierwsze, rozbieżności i różnice między Komunistyczną Partią Chin a innymi partiami komunistycznymi nie zaczęły się tylko od końca lat 70. XX w., kiedy w Chinach zaczęto wprowadzać nowe mechanizmy gospodarowania, określone później jako „socjalistyczna gospodarka rynkowa”. Różnice te nie powstały dopiero po śmierci Mao Zedonga we wrześniu 1976 r. Dawały one o sobie znać od początku powstawania Komunistycznej Partii Chin w lipcu 1921 r., kiedy powstała ona ze skromnej grupy chińskich marksistów, którzy na spotkaniu 1 lipca 1921 r. w Szanghaju ogłosili się jako Komunistyczna Partia Chin. KPCh powstała przy dużej pomocy założonej w 1919 r. Międzynarodówki Komunistycznej i jej radzieckich doradców, którzy w programie, strategii i taktyce działania nowej partii lansowali zastosowanie rewolucyjnej drogi w walce z burżuazyjno-obszarniczymi rządami w Chinach i o socjalizm w oparciu o wzory partii bolszewickiej w Rosji. Przypomnijmy, że leninowska koncepcja rewolucji proletariackiej polegała m.in. na organizowaniu proletariatu fabrycznego i zbrojne obalenie starego systemu, zdobycie władzy w głównych ośrodkach miejskich, a następnie poszczególnych regionach i całym kraju. I ten plan powiódł się w Rosji, choć walki rewolucyjne trwały kilka lat i m.in. w następstwie doprowadziły do dużych zniszczeń kraju. Fiasko natomiast poniosła druga część twierdzenia Lenina o możliwości zwycięstwa rewolucji proletariackiej w skali światowej, co komplikowało sytuację ideowo-polityczną partii komunistycznych nie tylko w Rosji. 
W Chinach była bardziej zacofana struktura gospodarcza i społeczna, przemysł był we wstępnej fazie rozwoju, głównie w miastach nadmorskich i w centrach, gdzie wydobywano cenne surowce. Około 90\% społeczeństwa zajmowało się rolnictwem, w większości byli to ekstremalnie biedni chłopi i wiejski proletariat. Proletariat przemysłowy obejmował nie więcej niż 1\% zatrudnionych i pozostawał pod silnym wpływem kapitału zagranicznego oraz wartości i zasad konfucjańskich. Koncepcja walki o władzę w Chinach w oparciu o słaby proletariat miejski - lansowana przez doradców Międzynarodówki Komunistycznej - załamała się w 1927 r., kiedy KPCh próbowała wzniecić powstanie antykapitalistyczne w miastach, ale próba ta zakończyła się masakrą komunistów przez wojska generała Czang Kaj-Szeka. W następnych latach odbudowę szeregów komunistycznej Partii Chin podjął Mao Zedong, budując ją w oparciu o proletariat wiejski i biednych chłopów. Po wielu latach ta nowa KPCh stała się silną organizacją, odrodziła ideologię komunistyczną w Chinach i po tzw. Długim Marszu w latach 1934-1935 ukształtowała się jako wielka rewolucyjna siła, która potrafiła zdobyć zaufanie chińskiego ludu swą konsekwencją $\mathrm{w}$ walce $\mathrm{z}$ okupantem japońskim i przeciwko rządom burżuazji oraz obszarników skupionych wokół Kuomintangu i generała Czang Kaj-Szeka. W 1949 r. prawie całe Chiny znajdowały się pod kontrolą Komunistycznej Partii Chin i 1 października Mao Zedong w Pekinie ogłosił powstanie Chińskiej Republiki Ludowej.

Przypomnienie tych podstawowych faktów historycznych było niezbędne, by wskazać odrębność chińskiej rewolucji, która od początku stawiała różne cele polityczne i gospodarcze. Była to walka z kapitalizmem, burżuazją i obszarnikami, z pozostałościami zmurszałego ustroju feudal- 
nego, odwiecznych struktur cesarskich, walka o reformę rolną, walka z samowolą tzw. „warlordów”, czyli generałów-watażków, którzy rujnowali kraj wojnami wewnętrznymi, walka z mocarstwami kolonialnymi, głównie z Japonią, walka od demokrację. Dopiero po zwycięstwie rewolucji w 1949 r. KPCh mogła postawić kwestię walki o przemiany socjalistyczne, które realizowano głównie w oparciu o przykład ZSRR, wzorując się na jego rozwiązaniach gospodarczych, polityczno-państwowych oraz korzystając z dużej pomocy finansowej, technicznej i kadrowej Związku Radzieckiego i europejskich państw demokracji ludowej. Dużym doświadczeniem w kształtowaniu nowego ustroju społecznego były tzw. „bazy radzieckie”, czyli wyzwolone w okresie walki o władzę tereny, na których kształtowały się początki instytucji i stosunków demokratycznych i socjalistycznych, co było oryginalne i nawet w początkowej fazie odróżniało chińską drogę do socjalizmu od rosyjskiej.

Przemiany realizowane od $1949 \mathrm{r}$. przyniosły po prawie trzydziestu latach latach rządów Mao Zedonga duże przekształcenia społeczno-gospodarcze i stworzyły stabilny fundament pod budowę socjalizmu w Chińskiej Republice Ludowej, przede wszystkim rozwijano przemysł ciężki, budowano nowoczesną infrastrukturę komunikacyjną, kształtowały się nowe wielkie oddziały proletariatu fabrycznego, na wsi zakładano spółdzielnie produkcyjne i rozwiązywano wielkie problemy egzystencjalne rolników. W nowych realiach politycznych i międzynarodowych Mao Zedong zrozumiał, że bez pomocy ZSRR i europejskich państw demokracji ludowej sprawa utrzymania władzy w Chinach przez komunistów, a przede wszystkim realizacja wielkich programów modernizacyjnych i rozwojowych chińskiej gospodarki w kierunku socjalizmu, może stanąć pod znakiem 
zapytania. Dlatego pilnie studiował doświadczenia rewolucyjnych przemian i budowy podstaw socjalizmu w ZSRR, był dla Chin Leninem oraz Stalinem i w swych pismach często nawiązywał do ich prac politycznych i teoretycznych, choć nie unikał także cytatów z prac konfucjańskich. Był wielkim rewolucjonistą, który stworzył podwaliny pod socjalizm i wprowadził ponownie Chiny na tory światowej polityki, ale także nie uniknął błędów, które były m.in. konsekwencją Wielkiego Skoku i Rewolucji kulturalnej. Błędy te wyrastały z woluntaryzmu Mao Zedonga i miały duże negatywne następstwa nie tylko dla Chin. Spowodowały także głębokie podziały w łonie międzynarodowego ruchu komunistycznego, co wiązało się też z głębokimi zmianami ideowo-politycznymi w ZSRR i KPZR po śmierci Stalina w 1953 r. i rewizjonistyczną polityką Nikity Chruszczowa i jego następców w Komunistycznej Partii Związku Radzieckiego.

Można więc skonstatować, że obecne różnice i rozbieżności między Komunistyczną Partią Chin a innymi partiami komunistycznymi nie są tylko wynikiem wdrożenia i realizacji „socjalistycznej gospodarki rynkowej” przez następcę Mao Zedonga Deng Xiaopinga i kolejne generacje chińskich komunistów, ale mają głębsze przyczyny i uzasadnienie w różnicach rozwoju gospodarczego i kulturalno-cywilizacyjnego Chin, ich odrębnej wiele tysięcy lat liczącej drogi rozwojowej, które Marks w połowie XIX w. określał jako azjatycki sposób produkcji i w związku z tym wszelkie próby przeniesienie rozwiązań oraz instytucji z innych kręgów kulturowych zawodziły i przynosiły fiasko. Chiny musiały poszukiwać własnej drogi do socjalizmu i jego budowy. Jest to problem w pełni aktualny dla licznych innych ludów i narodów kolonialnych oraz postkolonialnych Azji, Afryki 
i Ameryki Łacińskiej, które dążą do wyzwolenia się spod jarzma kolonializmu, neokolonializmu, kapitalizmu i imperializmu. Chińska droga do socjalizmu jest dla niektórych z nich bardzo atrakcyjnym projektem społeczno-politycznym i gospodarczym.

Kwestia wykorzystania rynku, a także dopuszczenia innych niż państwowy i spółdzielczy sektory gospodarczo-własnościowe przejawiała się nie tylko w Chinach. Jak wiadomo od czasów Marksa w ruchu robotniczym koncepcja gospodarki socjalistycznej oparta była o projekt gospodarki planowej z reguły w postaci scentralizowanej. Miała ona ustrzec społeczeństwo socjalistyczne od kryzysów i chaosu gospodarczego, charakterystycznych dla gospodarki kapitalistycznej. Trudności z wdrożeniem tej zasady wystąpiły od początku w radzieckiej Rosji i we wczesnych latach ZSRR, kiedy rewolucja rodziła się w wielkich bólach i możliwości ogarnięcia chaosu porewolucyjnego były przez bolszewików rozwiązywane w oparciu o zasady komunizmu wojennego. Rosja porewolucyjna stała przed olbrzymimi problemami będącymi następstwem zniszczeń gospodarczych w wyniku wojny i rewolucji. Kierownictwo RKP(b) na czele z Leninem zdecydowało się na zmianę taktyki i wdrożyli tzw. Nową Politykę Ekonomiczną (NEP), która zastąpiła warunki i mechanizmy komunizmu wojennego dopuszczeniem rynku oraz nową polityką podatkową. Powstały duże możliwości dla legalnej działalności dla gospodarki chłopskiej. Chłopi uzyskali duże możliwości dodatkowej produkcji i sprzedaży nadwyżek rolnych po cenach rynkowych, co przyczyniło się do lepszego zaspokojenia potrzeb żywnościowych mieszkańców miast. Oczywiście prowadziło to do rozwarstwienia wsi i wprowadzało stosunki drobnokapitalistyczne, ale w tym czasie władza bolszewików była już na tyle umocnio- 
na, że nie obawiano się jej obalenia, a jednocześnie lepiej rozwiązywano problemy zaopatrzenia oraz wymiany między miastem a wsią.

O wiele większym następstwem na rzecz rynku i aktywizacji sektora drobnokapitalistycznego było dopuszczenie do legalnego działania w zakresie drobnej produkcji przemysłowej i usług rodzimego drobnomieszczaństwa w miastach, a w znacznie szerszym kontekście dopuszczenie wielkich firm kapitału zagranicznego, który pod kontrolą radzieckiego państwa uzyskał duże możliwości działania, co przyczyniło się do znacznego ożywienia gospodarczego i jednocześnie odradzało stosunki kapitalistyczne w Rosji na szerszą skalę. Likwidacja Nowej Polityki Ekonomicznej nastąpiła w Związku Radzieckim pod koniec lat 20., kiedy wdrożono politykę kolektywizacji rolnictwa i scentralizowanej gospodarki planowej, której podstawą był pierwszy plan pięcioletni (lata 1929-1933).

Pewne elementy rynku występowały też w państwach demokracji ludowej w Europie, w szczególności w ich początkowej fazie funkcjonowania. W latach 1944-1945 powstawały państwa demokracji ludowej, które w oparciu o rewolucję ludowo-demokratyczną i budowę podstaw socjalizmu realizowały przemiany ustrojowe. W szczególności sektor drobnotowarowy był mocny w Polsce, głównie w rolnictwie, gdzie zdecydowanie dominowała gospodarka indywidualna, a próby jej uspółdzielczenia przynosiły ograniczone rezultaty (w 1955 r. maksimum 8\%). Po 1956 r. władze pod kierownictwem nowego pierwszego sekretarza Władysława Gomułki zrezygnowały z polityki forsowania kolektywizacji i przeszły na drogę stopniowych przekształceń oraz pośrednich form uspołecznienia rolnictwa. W Polsce po 1956 r. nastąpiło także ożywienie i wzrost sektora 
drobnokapitalistycznego w miastach, głównie w usługach i mniejszej produkcji przemysłowej w zakładach zatrudniających nie więcej niż 50 osób. Relatywnie duży był udział sektora drobnokapitalistycznego w Niemieckiej Republice Demokratycznej, funkcjonowała tam nawet środowiskowa partia polityczna - Partia Liberalno-Demoratyczna Niemiec, obsługująca ten sektor politycznie. Jeszcze większy był udział sektorów niespołecznych w gospodarce Jugosławii, w której duże możliwości działalności gospodarczej miały sektory prywatne w mieście i na wsi. W jugosłowiańskiej gospodarce duży był udział korporacji kapitalistycznych. Jugosławia była mocniej wciągana w mechanizmy gospodarki kapitalistycznej także w następstwie dużych możliwości podejmowania pracy przez jugosłowiańskich gastarbeiterów nie tylko w Republice Federalnej Niemiec. Jugosławia stworzyła oryginalną drogę przemian socjalistycznych i była mniej powiązana politycznie i gospodarczo ze Związkiem Radzieckim i państwami wspólnoty socjalistycznej.

Pozostałości sektorów gospodarki indywidualnej i gospodarki kapitalistycznej były konsekwencją słabego rozwoju sił wytwórczych, głównie przemysłu w państwach, które w XX w. wkroczyły na drogę rewolucji i budowy socjalizmu i konieczności znacznego wydłużenia okresu przejściowego od kapitalizmu do socjalizmu. Sektory drobnokapitalistyczne znacznie trudniej poddawały się mechanizmom zarządzania w ramach centralnego planowania i konserwowały warunki dla żywiołowo odradzającego się rynku drobnokapitalistycznego. Miało to swoje negatywne następstwa dla odradzających się sprzeczności społeczno-klasowych, wpływało na odradzanie i umacnianie stosunków kapitalistycznych, głównie w formie drobnomieszczańskiej, umacniało światopogląd burżuazyjno-kapitalistyczny i było ważnym 
instrumentem osłabiania ideologii socjalistycznej, ale nie miały one decydującego wpływu na zachowania polityczne ludzi pracy. Decydujące znaczenie miały wielkie ośrodki burżuazyjne świata kapitalistycznego, które wykorzystywały swą przewagę ekonomiczną i wojskową w walce z państwami socjalistycznymi oraz ideologią socjalistyczną, natomiast wykorzystywały drobny kapitalizm dla erozji socjalizmu. Próby ograniczania sektora drobnokapitalistycznego i przyspieszenia jego przekształceń także w oparciu metody administracyjne przynosiły np. w Polsce ograniczone rezultaty ekonomiczne, a jednocześnie spychało tę warstwę w ramiona burżuazji i osłabiało front sił prodemokratycznych, jak i prosocjalistycznych.

Kwestia wykorzystania sektorów drobnokapitalistycznych, a także wejścia na drogę większej kooperacji z wielkim zagranicznym kapitałem ujawniła się w Chińskiej Republice Ludowej w schyłkowych latach rządów Mao Zedonga, który był wychowankiem i kontynuatorem starej leninowskiej szkoły komunizmu, zakładającej szybkie, a nawet jak określał Marks w swych wcześniejszych pracach „błyskawiczne rewolucyjne przejście od kapitalizmu do socjalizmu” („auf einamal und gleichzeitlich"), co było uwarunkowane i uzasadnione rozwojem ówczesnych stosunków i sprzecznościami liberalnego kapitalizmu i co miało się odbyć w najbardziej rozwiniętych metropoliach kapitalizmu i niejako automatycznie pociągać zmiany w pozostałych państwach, w szczególności uzależnionych przez różne formy kolonializmu.

Historia jednak potoczyła się inaczej niż prognozowali to nawet najbardziej genialni myśliciele. Doświadczenia Komuny Paryskiej z 1871 r. potwierdziły wielką złożoność możliwości zwycięskiej rewolucji socjalistycznej w rozwi- 
niętej gospodarczo Francji, dysponującej dużymi osiągnięciami republikańskimi i demokracji burżuazyjnej. Francuska burżuazja wykorzystała swą przewagę wojskową oraz ekonomiczną i błyskawicznie przy pomocy pruskich okupantów rozprawiła się z Komuną Paryską. Jeszcze bardziej złożona była sytuacja w Rosji, w której bolszewicy pod wodzą Lenina stanęli na czele rosyjskiej rewolucji. W lutym 1917 r. obalono zmurszały carat, a w październiku 1917 r. obalono rządy burżuazyjno-obszarnicze. Jak się okazało, warunki i możliwości budowania nowego socjalistycznego społeczeństwa w Rosji były bardzo trudne i napotkały na niespotykane dotychczas bariery. Przede wszystkim dawała o sobie znać zacofana struktura społeczna, brak demokratycznych tradycji, zdecydowana większość społeczeństwa żyła z pracy na roli, przemysł wraz z rodzącą się dopiero klasą robotniczą stanowił niewielką część gospodarki i rozwijał się wyspowo w niektórych częściach Rosji. Bolszewicy wykorzystali dużą koncentrację przemysłowego proletariatu w głównych centrach miejskich i ośrodkach przemysłowych, zdobyli inicjatywę polityczną i wykorzystali słabość dawnego carskiego i burżuazyjnego aparatu państwowego, głównie armii i zdobywali coraz większe poparcie mas pracujących, w tym także biednych chłopów, których pozyskano hasłami pokoju i obietnicą zaspokojenia ich wiecznego głodu ziemi w konsekwencji parcelacji wielkich majątków obszarniczych. Ziemia w rewolucyjnej Rosji została upaństwowiona, podobnie jak przemysł i banki. Chłopi mieli prawo jej użytkowania, co rodziło później inne sprzeczności.

Podobna była, choć jeszcze bardziej skomplikowana, sytuacja w Chinach. Rewolucja demokratyczna i socjalistyczna kierowana przez KPCh rozwiązywała liczne dotychczasowe sprzeczności i pozwoliła znacznie poprawić warunki bytowe 
mas pracujących, głównym źródłem akumulacji było słabo rozwinięte rolnictwo i ręczna praca setek milionów ludzi. Przemysł był słabo rozwinięty i jego nacjonalizacja nie zmieniały jakościowo gospodarki chińskiej, dotyczyło to także przejętych nielicznych zakładów kapitału zagranicznego. Od początku rewolucji Chińska Republika Ludowa stanęła w obliczu embarga gospodarczego i sankcji państw imperialistycznych, a przede wszystkim bezpośredniego zagrożenia wojennego, które w całej okazałości wykazała agresja USA i ich sojuszników w Korei w latach 1950-1953, a później w Wietnamie. Dodatkowym czynnikiem komplikującymi sytuację gospodarczą i socjalną był wielki przyrost naturalny, który w ciągu jednego pokolenia doprowadził do prawie podwojenia liczby ludności i który relatywizował wielkie osiągnięcia gospodarki socjalistycznej, np. ciągle wielka była liczba osób, szczególnie na wsi, żyjących w warunkach ekstremalnej nędzy (300 mln).

W tej sytuacji w części kierownictwa KPCh rozwinęła się koncepcja przyspieszenia rozwoju społeczno-gospodarczego poprzez większe otwarcie na kapitały zagraniczne i aktywizację własnej wewnętrznej inicjatywy prywatnej. Koncepcję tę bardzo ostro zwalczał Mao Zedong i zwolennicy tzw. „koszarowego socjalizmu”. Mao określał ją jako odejście od socjalizmu, a nawet jego zdradę, oskarżając jej zwolenników jako „kroczących drogą kapitalistyczną”, których okrutnie karał, odsuwał od stanowisk, więził i często zsyłał na daleką, głuchą wieś do obozów odosobnienia, by tam uczyli się szacunku do pracy od często prymitywnych wieśniaków. Doświadczyli tego Deng Xiaoping, który przez wiele lat odsunięty został z kierownictwa partii, ale przeżył "wiejską edukację", a także Liu Shaotsi (były Przewodniczący ChRL), który w wyniku ciężkich warunków zmarł na wy- 
gnaniu. Dotyczyło to także ojca obecnego Przewodniczącego ChRL i sekretarza generalnego KPCh Xi Jinpinga, który w latach 60. pełnił funkcję wicepremiera rządu ChRL. Był on zesłany wraz z rodziną i bez wątpienia odbiło się to na losach byłego wicepremiera, a także jego syna, który nabierał tam nowego doświadczenia społeczno-politycznego. Wymienia się tu tylko kilka nazwisk, problem miał jednak charakter masowy i dowodzi, jak głębokie podziały dzieliły całą partię i społeczeństwo.

Deng Xiaoping i jego towarzysze wychodzili z założenia, że socjalizm w Chinach mocno się zakotwiczył i nie zagraża mu niebezpieczeństwo kontrrewolucji. Ludzie pracy zaspokoili swe podstawowe potrzeby społeczne, ale mówiąc obrazowo socjalizm rozbudził apetyt społeczeństwa nie tylko na zaspokojenie potrzeb żywnościowych, także dóbr wyższego rzędu, ale gospodarka chińska nadal chronicznie cierpiała na brak kapitałów zewnętrznych i szerokiego styku z rozwiniętymi produkcyjnie i technologicznie gospodarkami, a możliwości wewnętrzne były bardzo ograniczone. Doskwierały wspomniane sankcje i embargo. Doświadczenia sąsiedniego Singapuru i innych tzw. „tygrysów azjatyckich”, w tym Hongkongu, Tajwanu i Korei Południowej dowodziły, że to otwarcie może mieć duże korzystne następstwa dla rozwoju i modernizacji chińskiej gospodarki. Koncepcja Deng Xiaopinga nie zakładała absolutnie ideowo-politycznego poddania się KPCh i ChRL hegemonii amerykańskiej i likwidacji socjalizmu. Nowe kierownictwo Chin wyciągnęło wnioski z kapitulanckiej polityki KPZR i państw demokracji ludowej w Europie, które zdradziły socjalizm, porozumiały się z siłami antykomunistycznymi i przeszły na stronę kontrrewolucji. KPCh zmieniła taktykę, ale nie strategię podążania do socjalizmu, a w dalszej perspektywie do ko- 
munizmu, traktując tę drogę jako podstawę do odmiennego traktowania okresu przejściowego od kapitalizmu do socjalizmu, znacznie wydłużoną, jako niezbędny etap przemian gospodarczych i społecznych, wymagający wszechstronnej modernizacji gospodarki, w szczególności nowoczesnych gałęzi przemysłowych, komunikacji, zarządzania, a także przyspieszenia zmian struktury społeczno-klasowej w kraju, który z powodów historycznych startował do socjalizmu z bardzo niskiego poziomu rozwoju i co wymaga nie lat, lecz ich dziesiątków, a nawet setkę, tak jak to obecnie realistycznie oceniają dokumenty zjazdowe KPCh. Oznaczało to głównie przyspieszenie rozwoju nowoczesnych sił wytwórczych na miarę już nie tylko przemysłową, lecz rewolucji naukowo-technicznej, społeczeństwa wiedzy, szybką urbanizację kraju, powstanie i rozwój nowoczesnych oddziałów klasy robotniczej, rozwój i upowszechnienie zdobyczy oświaty kultury oraz stopniowe zmniejszanie zatrudnienia w rolnictwie, jego modernizację i stopniowe uspołecznienie. Drogą do tego było rozwiązanie dotychczasowych komun ludowych, przekazanie hektarowych działek ziemi w użytkowanie na trzydzieści lat rodzinom chłopskim, żeby miały one minimum w zakresie utrzymania się, a jednocześnie ekonomicznej aktywizacji wielkiego potencjału nadwyżek wiejskiej siły roboczej w dynamicznie rozwijających się miastach nadmorskich i w Chinach centralnych. Uruchomiło to wielką armię tzw. robotników sezonowych, liczącą obecnie około $280 \mathrm{mln}$ ludzi, która jest jednym z kół zamachowych dynamicznego rozwoju ChRL w ciągu ostatnich więcej niż czterdziestu lat.

Oczywiście ujawniły się także słabsze strony tej koncepcji. Jest to częściowe uzależnienie od światowej gospodarki kapitalistycznej, mającej globalny charakter, od kapitałów państw imperialistycznych, które zainwestowały w Chi- 
nach biliony dolarów i odtwarzają na masową skalę wartości i stosunki kapitalistyczne. Pojawiły się głębokie różnice w dochodach, odrodziła się nie tylko mała i średnia, także wielka burżuazja chińska, która wchodzi w relacje finansowo-ekonomiczne ze wszystkimi grupami zagranicznego kapitału, ale na ogół politycznie i ideowo zachowuje się lojalnie w stosunku do własnego socjalistycznego państwa i partii komunistycznej. Nie oznacza to, że „po cichu” nie dąży ona do zmiany obecnego kapitalizmu państwowego na „normalny” kapitalizm, o czym świadczą ruchy dysydenckie typu Liu Xiaobo - laureata Pokojowej Nagrody Nobla sprzed ponad dziesięciu lat. Gospodarka rynkowa pogłębiła wielkie sprzeczności społeczne i walka klasowa w Chinach zaostrza się na tle nie tylko pogłębiającego się rozwarstwienia finansowo-ekonomicznego, także w stosunkach międzynarodowych, głównie za sprawą wielkiej konkurencyjności chińskiej produkcji na światowych rynkach i m.in. wyraża się wielkim uzależnieniu USA i najbardziej rozwiniętych państw Unii Europejskiej od taniej produkcji i towarów chińskich. W tej sytuacji b. prezydent USA D. Trump ogłosił nową wojnę handlową z Chinami (nową zimną wojnę) i nałożył na nie nowe embargo, sankcje i restrykcje celno-finansowe. Politycy amerykańscy nie wykluczają w ciągu następnych dziesięciu lat wejścia USA nawet w jakiś poważny konflikt wojenny z Chinami. W 2020 r. nastąpiła zmiana administracji federalnej w USA, prezydentem został kandydat Demokratów Joe Biden, także partii wielkiego kapitału, bardziej jednak otwartej na kwestie socjalne biedniejszych grup elektoratu, który zapowiedział liczne zmiany w odróżnieniu od polityki swego poprzednika, ale kontynuację polityki Trumpa w relacjach z Chińską Republiką Ludową. Oznacza to, że w relacjach międzynarodowych ChRL jest 
głównym przeciwnikiem USA i przesunięcie ich głównych akcentów na Daleki Wschód jest wyrazem nie tylko wielkiego potencjału gospodarczego Chin, ale także odmienności polityczno-ustrojowej socjalistycznego państwa rządzonego przez komunistów.

W następstwie upadku Komunistycznej Partii Związku Radzieckiego i ZSRR Chińska Republika Ludowa stała się w sposób niemal naturalny nowym światowym centrum postępu społecznego, walki o socjalizm, z kapitalizmem i imperializmem, walki o pokój i przeciwko wojnie. Komunistyczna Partia Chin i inne podmioty polityczne rozwijają liczne inicjatywy mające na celu rozwój współpracy z wszystkimi postępowymi siłami na świecie. Odnosi się to do partii komunistycznych, socjalistycznych, socjaldemokratycznych, ruchów ekologicznych a nawet postępowych nurtów sił prokapitalistycznych. Jako stały członek Rady Bezpieczeństwa ma wielkie możliwości działania politycznego w ramach systemu ONZ. Chiny są także aktywne w ruchu państw niezaangażowanych, w którym przejawia różne formy aktywności ideowo-politycznej, a przede wszystkim gospodarczej. Można nawet stwierdzić, że ten kierunek aktywności skierowany na państwa dawniej nazywane państwami Trzeciego Świata, a dziś państwami rozwijającymi się jest bardzo ważny, a nawet strategiczny nie tylko dla Chin, ale i świata. Są to najczęściej państwa Afryki, Azji Południowej, Ameryki Łacińskiej. Głównym instrumentami tej polityki są wielkie projekty gospodarcze i w zakresie infrastruktury rozwijane w ramach tzw. Nowych Jedwabnych Szlaków (One Belt One Road), na które rząd chiński w latach 2016-2020 wydał ok. 8 bln dolarów, rozwijane w celu zwiększenia i rozszerzenia wymiany handlowej Chin, ale także mające na celu wyjście z izolacji i okrążania Chin przez państwa imperialistyczne. 
Nowe szlaki handlowe budowane są jako alternatywa wobec ewentualnej możliwości blokady wojskowej przez państwa imperialistyczne dotychczasowych dróg handlowych i odcięcia Chin np. od dostaw ropy naftowej ze źródeł Bliskiego Wschodu i Iranu. Jednocześnie chińskie korporacje inwestują na bardzo korzystnych warunkach w tych krajach, co jest nie tylko formą korzystnej pomocy dla nich, ale także pośrednio propagowania chińskich instytucji i stosunków osiągnięć socjalizmu z chińską specyfiką. Pod tym względem Chiny ludowe kontynuują radziecką politykę wspierania $\mathrm{w}$ drugiej połowie $\mathrm{XX}$ w. sił postępowych w tych państwach, niektóre z nich ogłosiły wtedy możliwości rozwoju niekapitalistycznej drogi rozwoju, co było ważnym czynnikiem ich walki z neokolonializmem. Chiny także zwiększyły swą aktywność w ruch państw niezaangażowanych, o czym już wspomniano. Wszystko to powoduje, że Komunistyczna Partia Chin i Chińska Republika Ludowa stają się nieoficjalnie nowym światowym centrum postępu społecznego, walki z kapitalizmem, o pokój i socjalizm. Podążają one odmienną drogą do socjalizmu, która nie może nie uwzględniać następstw i właściwości chińskiej kultury oraz cywilizacji i jest to fenomen, który nie jest przyjmowany ze zrozumieniem przez niektóre partie komunistyczne, w szczególności z kręgu europejskiego, na ogół stojących na stanowisku „ortodoksyjnego marksizmu”, zakładającego, że rewolucje socjalistyczne muszą wybuchać w najbardziej rozwiniętych państwach europejskich, ewentualnie także w USA, Kanadzie, a z krajów azjatyckich w Japonii, gdzie jednak kapitalizm mocno się „okopał” i mimo że obiektywnie są tam warunki rozwojowe i przesłanki ekonomiczne dla wprowadzenia ustroju socjalistycznego, to stosunki kapitalistyczne zapewnione są przez dominację militarno-policyjną i pano- 
wanie ideowo-polityczne kapitału. Partie i ośrodki burżuazyjne skutecznie utrzymują rządy wielkiego kapitału mimo cyklicznych kryzysów gospodarczo-finansowych, dzięki także częściowo zrealizowanym reformom i polityce partii socjaldemokratycznych, które wprowadziły pewne programy łagodzące sprzeczności społeczno-klasowe i zapobiegające narastaniu i pogłębianiu radykalizmu społecznego.

Konkludując ten wątek możemy stwierdzić, że międzynarodowa polityka Chińskiej Republiki Ludowej jest w dużym stopniu uogólnieniem rewolucyjnego doświadczenia KPCh, w której główną siłą walki o demokrację i socjalizm stały się wielkie rzesze wiejskiego proletariatu i biednego chłopstwa, które pod kierunkiem KPCh osiągnęły w 1949 r. epokowe zwycięstwo. Obecna polityka międzynarodowa KPCh, także wielkie projekty Nowych Jedwabnych Szlaków są adresowane głównie do biednych ludów planety, radykalizują one miejscowe siły rewolucyjne i w ten sposób tworzy się i umacnia front antyimperialistyczny, złożony głównie z proletariatu państw rozwijających się, który otacza i spycha światowy imperializm do swoistego historycznego „narożnika”. „Światowa wieś” za sprawą wielkich i socjalistycznych Chin tworzy nowe fronty walki głównie $\mathrm{z}$ imperializmem USA i podlegającymi im NATO, ANZUS-em i wieloma innymi strukturami nie tylko militarno-wojskowymi światowego kapitalizmu. Wydaje się, że kwestia tej sprzeczności i odejścia od dotychczasowej taktyki walki o postęp społeczny i socjalizm jest głównym problemem teoretycznym, politycznym oraz ideologicznym współczesnego międzynarodowego ruchu robotniczego i komunistycznego.

Jakie argumenty przedstawiają rzecznicy tradycyjnych nurtów teoretycznych marksizmu w tej kwestii. Na ten 
temat toczy się ożywiona dyskusja w komunistycznych środkach masowego przekazu, na międzynarodowych konferencjach teoretyczno-politycznych i w poszczególnych partiach. Poglądy te reprezentowane są przez niektórych teoretyków i działaczy Komunistycznej Partii Grecji, Komunistycznej Partii Niemiec (KPD), a w ostatnim okresie przez środowiska skupione wokół czasopisma teoretycznego, wydawanego w Niemczech Zachodnich (Hannover), w którym ukazał się m.in. obszerny artykuł Juergena Gepperta pt. Politische Analyse Chinas, którego podstawowe tezy wraz z komentarzem zostaną przedstawione w dalszej części pracy ${ }^{1}$.

Krytycy socjalistycznej gospodarki rynkowej, a także chińskiej drogi do socjalizmu, w szczególności po śmierci Mao Zedonga we wrześniu 1976 r. wychodzą z podstawowego założenia, że zmiany w Chinach są częścią wielkiego światowego odchodzenia od socjalizmu i przechodzenia większości partii ruchu komunistycznego na pozycje nowego rewizjonizmu i reformizmu, które inaczej niż ich dawne nurty, zmierzające do osłabienia ruchu robotniczego i wmontowania go w część systemu kapitalistycznego (co dotyczyło głównie starej socjaldemokracji), to obecne nurty zmierzają nie tyle do jego osłabienia, lecz do całkowitego obalenia „realnego socjalizmu”. Jest to więc o wiele bardziej szkodliwa działalność teoretyczna i ideowo-polityczna. Jako takie nurty te wpisują się w walkę między kapitalizmem i komunizmem oraz służą kontrrewolucji. Tak należy rozumieć wszystkie te nurty, które przedstawiają się jako „teoria socjalistycznej gospodarki rynkowej” i są one dużym zagrożeniem nie tylko dla poszczególnych partii, ale w ogóle dla

1 Zob. m.in.: J. Geppert, Politische Analyse Chinas, „offen-siv”; Zeitschrift fuer Sozialismus und Frieden, marzec-kwiecień 2021, nr 3, s. $43-86$. 
całego międzynarodowego ruchu komunistycznego, gdyż osłabiają one ideologicznie partie i rozbijają je politycznie. Powstają w nich nieoficjalne frakcje, działające podskórnie i przyczyniają się nie tylko do osłabienia, ale nawet ich likwidacji. Dobrymi przykładami na potwierdzenie tych tez są losy partii robotniczych i komunistycznych w dawnym ZSRR i innych państwach tzw. realnego socjalizmu w Europie, a w szczególności w schyłkowym okresie Węgierskiej Republiki Ludowej, a także w Polsce w dawnej PZPR, w której większość kierownictwa w końcu lat 80 . XX w. przeszła na pozycje kontrrewolucji, zdradziła resztki socjalizmu i w lutym 1990 r. na swym ostatnim zjeździe rozwiązała się, dokonując politycznego samobójstwo.

Zarysowane zjawiska ideowo-polityczne miały swą historię, a nawet wcześniejsze przyczyny osłabiające ruch robotniczy we wcześniejszych fazach jego rozwoju. W szczególności należy wskazać wielkie zagrożenia rewizjonistyczne i reformistyczne, które wystąpiły pod koniec XIX w., objęły większość ówczesnych partii socjaldemokratycznych i doprowadziły do załamania się ówczesnego ruchu robotniczego i przekształcenia się socjaldemokracji w siły antysocjalistyczne, co było jedną z przyczyn wybuchu I wojny światowej, a w okresie międzywojennym do osłabienia nie tylko walki o socjalizm, ale i wybuchu nowej II wojny światowej. Obecna epoka po upadku ZSRR i realnego socjalizmu w Europie wpisuje się logicznie w te procesy, osłabiające sprawę socjalizmu i komunizmu na świecie.

Jako dalsze przykłady działalności tych niszczących sił można wskazać na Komunistyczną Partię Hiszpanii, będącej w drugiej. poł. XX w. jedną z silniejszych partii komunistycznych w Europie Zachodniej, która pod koniec XX w. została bardzo osłabiona i z czasem całkowicie upadła. 
Głównymi przyczynami było m.in. przejście jej kierownictwa na pozycje eurokomunizmu. Po upadku reżimu gen. Franco ogłosiła się nawet zwolenniczką monarchii konstytucyjnej i burżuazyjnego systemu wielopartyjnego. W następnych latach baza partyjna uległa dalszym podziałom ideologicznym i KPCh stała się partią marginesu politycznego. Podobne losy spotkały kiedyś przodującą w Europie Komunistyczną Partię Francji. W latach 70. XX w. przekształciła się ona w partię eurokomunistyczną, dystansującą się od „sowieckiego komunizmu”, w 2013 r. zrezygnowała z sierpa i młota jako logo partii. W rezultacie jedność ideowo-polityczna partii uległa głębokiej erozji, powstały różne grupy i frakcje, a w 2017 r. w wyborach KPF otrzymała poparcie zaledwie 2,49\% głosów. Komunistyczna Partia Włoch także wstąpiła na ścieżkę eurokomunizmu, wcześniej niż KPF, zadeklarowała nawet, że NATO jest gwarantem włoskiej drogi do socjalizmu. W 1991 r. KPW zmieniła nazwę na Demokratyczną Partię Lewicy, niemającą nic wspólnego z ideologią komunistyczną. To tylko niektóre przykłady ideologicznej i politycznej erozji ruchu komunistycznego w Europie, które doprowadziły wymienione partie do marginalizacji, a nawet upadku. Przed podobnym losem stoi, zdaniem krytyków socjalistycznej gospodarki rynkowej i chińskiej drogi do socjalizmu, obecna Komunistyczna Partia Chin, kontynuująca konsekwentnie reformy gospodarcze i polityczne, rozpoczęte w Chińskiej Republice Ludowej przed ponad czterdziestu latach przez Deng Xiaopinga i jego następców ${ }^{2}$.

Jednocześnie należy zauważyć, że na chińską drogę do socjalizmu, a przede wszystkim mechanizm socjalistycznej gospodarki rynkowej z zainteresowaniem patrzą, a nawet

2 Więcej na ten temat wypowiedziała się Redakcja ww. wydania „offen-siv", Fazit, s. 86-88. 
wdrażają jej niektóre instytucje gospodarcze i stosunki niektóre państwa rozwijające się, a nawet socjalistyczne, np. od dawna Wietnam jako „socjalistycznie sterowaną gospodarkę" - od 2002 r., a ostatnio także Kuba, która na VIII Zjeździe Komunistycznej Partii Kuby (Havana 16-19 kwietnia 2021 r.) zapowiedziała wdrożenie pewnych elementów tej gospodarki w swej praktyce ekonomicznej. Nawet niektóre przedsiębiorstwa KRLD kooperują w bardzo ograniczonym zakresie z przedsiębiorstwami Korei Płd.

\section{Rozwój Chińskiej Republiki Ludowej w latach 1949- -2021 przez sprzeczności}

W opinii czołowych ośrodków burżuazyjnych Chińska Republika Ludowa cechuje się rosnącym potencjałem, stabilnym rozwojem i wzrostem gospodarczym, zwycięsko rozwiązuje wielkie historycznie uwarunkowane problemy chroniczne i społeczne. Stała się także wielką potęgą wojskową i bez wątpienia jest już nie tylko mocarstwem regionalnym (kontynentalnym), ale rości sobie pretensje do wpływania i decydowania w skali światowej, a co najważniejsze, nie uznaje ona hegemonii światowego kapitalizmu oraz imperializmu i przewodzącym im Stanom Zjednoczonym Ameryki Północnej.

Chińska Republika Ludowa powstała w 1949 r. w rezultacie wieloletnich zmagań Komunistycznej Partii Chin z siłami reakcyjno-burżuazyjnymi pod kierownictwem $\mathrm{Ku}$ omintangu i gen. Czang Kaj-Szeka i wspomagającymi ich zagranicznymi mocarstwami imperialistyczno-kolonialnymi, głównie USA, które w XIX w. dążyły do narzucenia Chinom panowania kolonialnego, głównie Rosja carska, Anglia, 
Francja i Niemcy, a po I wojnie światowej do 1945 r. także Japonia i USA. Przełomowe znaczenie tak w aspekcie wewnętrznym, jak i zagranicznym miało zwycięstwo Komunistycznej Partii Chin w 1949 r. i powstanie 1 października tego roku Chińskiej Republiki Ludowej.

Historia ChRL liczy już ponad siedemdziesiąt lat, co oznacza, że wyrosły już trzy pokolenia Chińczyków, którzy żyją i kształtują się w państwie socjalistycznym. Ten okres jest długi dla życia człowieka, ale chińska cywilizacja trwa już ponad 5 tys., a chińska państwowość 4 tys. lat, w związku z tym Chińczycy mają inny stosunek do długowieczności. Powstanie socjalizmu w Chinach jest jakościowo nowym etapem w rozwoju historycznym Chin, niemającym precedensu w świecie. W historii ludzkości występowały także inne cywilizacje w starożytności, ale, tak jak w Indiach, Mezopotamii, Egipcie, Grecji i starożytnym Rzymie, po pewnym czasie upadały w rezultacie nierozwiązanych sprzeczności wewnętrznych bądź wojen narzuconych przez silniejszych przeciwników. Inaczej było i jest z Chinami, które także przechodziły okresy wielkich zwycięstw, ale także słabości i załamań. Potrafiły one jednak nawet po wielkich katastrofach historycznym wrócić do dawnej świetności, odbudować kraj, gospodarkę i rozwijać kulturę oraz chińską cywilizację. Nowy etap rozwoju Chin nastąpił po zwycięstwie antykapitalistycznej, antykolonialnej i demokratycznej rewolucji, która pod kierunkiem Komunistycznej Partii Chin w następnych latach przystąpiła do budowy podstaw socjalizmu.

Dzieje ludowych Chin można podzielić na dwa okresy: 1. lata 1949-1976; 2. lata 1977-2021. Pierwszy okres określony był głównie przez kierownictwo Mao Zedonga, który przyniósł Chinom nie tylko rewolucyjne zmiany, także szyb- 
ki rozwój społeczno-gospodarczy, który był następstwem zmian w sposobie gospodarowania, także w olbrzymim przyroście ludności, który przyniósł prawie podwojenie liczby ludności z około 500 do $900 \mathrm{mln}$ ludzi. Mao Zedong należał, podobnie jak Stalin, do typu starych przywódców komunistycznych, liczących głównie na własne siły i jednocześnie mobilizujących je do maksymalnego wysiłku za cenę nawet wielkich ofiar. Było to uwarunkowane słabością potencjału gospodarczego, odziedziczonego po poprzednich epokach, a także przez systematyczne restrykcje gospodarcze i handlowe oraz zagrożenia militarne ze strony państw imperialistycznych. Młode państwa socjalistyczne musiały wydawać olbrzymie środki na rozwój i modernizację armii wobec stałego zagrożenia ze strony państw imperialistycznych. Dobitnie potwierdziła to historia Związku Radzieckiego, II wojny światowej i zimnej wojny po 1949 r., narzuconej przez USA i NATO.

Drugi okres w rozwoju Chin nastąpił po śmierci Mao Zedonga we wrześniu 1976 r. i około dwuletnim okresie zawirowań ideowo-politycznych, będących wyrazem głębokich podziałów politycznych w łonie kierownictwa Komunistycznej Partii Chin. Z czasem ster rządów w KPCh i państwie opanowany został przez skrzydło pragmatyków i reformatorów na czele z Deng Xiaopingiem, które wyszło z podstawowego założenia, że Chiny wyczerpały wszelkie zasoby polityki opierania się na własnych siłach. Gospodarce Chin potrzebne było nowe, niezbędne pchnięcie naprzód, co umożliwiały olbrzymie terytorium kraju, jego wielkie bogactwa naturalne i potężne zasoby siły roboczej, wykorzystywanej dotychczas mało efektywnie ze względu na słabe uzbrojenie pracy w nowoczesne środki produkcji, w szczególności nowoczesne technologie. Gospodarce chińskiej 
niezbędne było szerokie otwarcie i współpraca z nowoczesnymi, wysoko rozwiniętymi gospodarkami kapitalistycznymi, dysonującymi także potężnymi kapitałami finansowymi i naukowo-technologicznymi. Dobrymi przykładami takiego szybkiego rozwoju były doświadczenia sąsiedniego Singapuru, Korei Południowej, Tajwanu (nazywanymi często „azjatyckimi tygrysami”), przy czym Chiny poszukiwały innej formuły wzajemnych relacji z wielkim kapitałem zagranicznym. Deng Xiaoping i jego grupa uważali, że polityce reform i otwarcia sprzyja też sytuacja międzynarodowa. Lata 70. XX w. były czasem odprężenia między światowym socjalizmem a kapitalizmem, co sprzyjało rozwojowi i pogłębieniem wzajemnie korzystnych kontaktów.

W polityce międzynarodowej odnotowano wygaszanie dotychczasowych wojen, np. w Wietnamie, wcześniej w Korei i na Bliskim Wschodzie, w Europie doszło do spadku napięcia po uznaniu przez państwa status quo w Niemczech i uznaniu Niemieckiej Republiki Demokratycznej, co było w szczególności zasługą Konferencji Współpracy w Helsinkach w 1975 r. Doszło także do osłabienia napięcia na Bliskim Wschodzie, co m.in. zaowocowało powstaniem Autonomii Palestyńskiej i jej przyjęciem do ONZ. W konsekwencji tych procesów wzrosła wymiana handlowa i współpraca gospodarcza między państwami Wschodu i Zachodu, która była dobrym prognostykiem dla polityki otwarcia w Chinach.

Nowe kierownictwo KPCh trafnie diagnozowało sytuację międzynarodową, otwierając się jednocześnie na współpracę z przodującymi gospodarkami kapitalistycznymi. Uważało ono, że ChRL nie grozi uzależnienie od kapitalizmu, tak jak to było w przypadku Indii, Japonii, Indonezji, a przede wszystkim tzw. „azjatyckich tygrysów”, co było odzwiercie- 
dleniem kształtowania się neokolonializmu. Chińska Republika Ludowa i jej gospodarka w ciągu minionych trzydziestu lat osiągnęła olbrzymi potencjał i ze względu na ustrój socjalistyczny nie obawiała się, że zostanie uzależniona i wchłonięta przez gospodarkę kapitalistyczną i imperializm amerykański, czego obawiał się Mao Zedong. Ustrój socjalistyczny w Chinach po trzydziestu latach okrzepł i wzmocnił się. Gospodarka oparta była głównie na przedsiębiorstwach państwowych, zarządzana w ramach centralnego planowania, na wsi powszechne były gospodarstwa spółdzielcze (komuny ludowe), ziemia jednak była własnością państwa, co było kontynuacją odwiecznych stosunków własnościowych w Chinach. W tym okresie główna sprzeczność między kapitalizmem i socjalizmem dzieliła głównie Związek Radziecki (i uzależnione od niego państwa demokracji ludowej) i główne państwa kapitalistyczne na czele z USA. Chińska Republika Ludowa po zerwaniu na początku lat 60 . ze wspólnotą państw socjalistycznych stała z boku, a nawet ZSRR uważany był jako bardziej niebezpieczny przeciwnik. Ta sytuacja postrzegana była przez czołowe ośrodki burżuazyjne jako korzystna i że ChRL przestała być zagrożeniem dla kapitalizmu, była kokietowana, a nawet ośrodki burżuazyjne dostrzegły możliwości robienia z nią korzystnych interesów.

Innym problemem było, że Chiny cierpiały na brak kontaktów z rozwiniętymi gospodarkami świata, nie tylko kapitalistycznymi. Poczynając od lat 60 . ubiegłego wieku popsuły się stosunki między KPCh a KPZR i z czasem nastąpił rozpad wspólnoty państw socjalistycznych. Bezpośrednią przyczyną były rozbieżności ideowo-polityczne po śmierci Stalina w marcu 1956 r., a w szczególności po XX Zjeździe KPZR w lutym 1956 r., kiedy nowy pierwszy sekretarz Nikita Chruszczow w tzw. „tajnym referacie” krytycznie odniósł 
się do polityki Stalina i oskarżył go o niepotrzebny terror w latach 30. oraz liczne błędy w polityce międzynarodowej, które miały przyczynić się do wybuchu II wojny światowej i napaści hitlerowskich Niemiec w czerwcu 1941 r. na ZSRR, co przyniosło krajowi olbrzymie straty. Oskarżenia te były nieprawdziwe lub przejaskrawione i w rzeczywistości były zakwestionowaniem budownictwa socjalistycznego w ZSRR, co kontynuowane było w nie tak intensywnej skali po odsunięciu Chruszczowa od władzy w 1964 r. i przejęciu jej przez nowego pierwszego sekretarza KC PZPR Leonida Breżniewa i przyspieszenia kursu ku kapitalizmowi przez politykę Michaiła Gorbaczowa w latach 1985-1991, który doprowadził do całkowitego upadku socjalizmu w ZSRR i zwycięstwa kontrrewolucji, odrodzenia kapitalizmu i rozpadu ZSRR. Była to największa klęska nie tylko socjalizmu w ZSRR, ale także międzynarodowego ruchu robotniczego i komunistycznego.

Te procesy ideowo-polityczne w KPZR i ZSRR były bacznie obserwowane w Chinach. Potwierdziły one, że Chruszczow i schyłkowa KPZR schodziły z pozycji komunistycznych i weszły na tory polityki rewizjonizmu, reformizmu i oportunizmu, które osłabiały nie tylko KPZR, ale także cały międzynarodowy ruch komunistyczny i robotniczy. Kierownictwo KPCh zdawało sobie sprawę, że polityka ta jest bardzo niebezpieczna dla całego postępowego świata i że jednocześnie Komunistyczna Partia Chin ze względu na wielkość partii i kraju ma obowiązek obrony wielkiego dziedzictwa międzynarodowego ruchu komunistycznego. W tym czasie jednak KPCh nie dysponowała wystarczającym autorytetem międzynarodowym, a Chiny nie dysponowały także odpowiednim potencjałem gospodarczym, co spowodowało, że w schyłkowych latach XX w. międzyna- 
rodowy ruch robotniczy i komunistyczny został wyraźnie osłabiony. Upadł nie tylko Związek Radziecki i wspólnota państw socjalistycznych, osłabiony został także międzynarodowy ruch robotniczy oraz ruch ludów wyzwalających się od zależności kolonialnej i neokolonialnej. Jednocześnie umacniał się kapitalizm i imperializm, który kierowany przez USA tworzył podstawy „nowego światowego porządku". Znamionowały go nowe imperialistyczne wojny w Iraku, Afganistanie, ponownie w Iraku i na Bliskim Wschodzie. Powstały także inne ogniska zapalne na świecie.

Upadek KPZR i ZSRR, a także KDL-ów w Europie były wielką klęską ruchu robotniczego i komunistycznego, które przesłoniły dotychczasową historyczną porażkę ruchu robotniczego, jaką był upadek w 1871 r. Komuny Paryskiej. Jednocześnie nastąpiło jego głębokie rozbicie i podziały na różne frakcje, na wzrost oportunizmu, reformizmu i rewizjonizmu. Nastąpił wzrost różnych kierunków ideowych burżuazyjno-kapitalistycznych, w tym nacjonalizmu i nowoczesnych form faszyzmu. Święciły triumfy tezy głównych architektów walki z komunizmem, m.in. Zbigniewa Brzezińskiego („nowy światowy porządek”) i Francisa Fukuyamy („koniec historii”), a więc konieczności powrotu świata w stare, sprawdzone koleiny kapitalizmu pod łaskawą hegemonią USA. Oczywiście w tym czasie Komunistyczna Partia Chin i jej kierownictwo nie mogła aspirować do roli lidera ruchu komunistycznego na arenie międzynarodowej, bowiem stałyby się one niechybnie celem najbardziej reakcyjnych sił burżuazyjno-kapitalistycznych. Po raz kolejny KPCh umiejętnie wykorzystała historyczną szansę, stojąc z boku głównego frontu walki między USA a schyłkowym ZSRR.

KPCh i Chińska Republika Ludowa za politykę otwarcia i reform gospodarczych oferowała międzynarodowemu 
kapitałowi olbrzymi prawie miliardowy rynek, wielkie bogactwa naturalne i kraj liczący wiele setek milionów zasoby siły roboczej. Gra szła o olbrzymią stawkę, którą podjęły państwa kapitalistyczne oraz ich wielkie korporacje przemysłowe i banki. Wychodziły one z założenia, że Chiny są łatwą zdobyczą, łatwiejszą niż dawny Związek Radziecki, w którym już zagnieździły się na dobre. KPCh jednak nie dopuściła się zdrady ideałów socjalistycznych, ich wartości i zasad, wpuściła do Chin kapitał prywatny z zagranicy, głównie technologiczny i finansowo-bankowy, ale na swoich warunkach politycznych i gospodarczych, wyznaczając granice stref specjalnych, warunki i ograniczenia prawno-organizacyjne zagranicznych podmiotów gospodarczych i nie rezygnując $\mathrm{z}$ wiodącej roli własnej waluty - juana w rozliczeniach wewnętrznych i z partnerami zagranicznymi, określając jego wartość i stosunek do dolara przez kontrolowany przez państwo Centralny Bank Ludowy. Chiny przystąpiły do Światowej Organizacji Handlu, Międzynarodowego Funduszu Walutowego i Banku Światowego, wykorzystując członkostwo oraz aktywność do ochrony własnych interesów i stając się uznanym partnerem na światowych rynkach finansowych. Co prawda juan nie jest jeszcze walutą w pełni wymienialną, ale należy do międzynarodowego koszyka walut i z reguły chińskie transakcje z partnerami zagranicznymi rozliczane są w chińskiej walucie. Od partnerów zagranicznych wymagają respektowania Konstytucji ChRL i chińskich ustaw, zasad postępowego Kodeksu pracy oraz respektowania wolności działania związków zawodowych w przedsiębiorstwach prywatnych i kapitału zagranicznego, a nawet podstawowych organizacji partyjnych KPCh. Była to więc zasadnicza różnica w relacjach Chin ze spółkami kapitalistycznymi i z kapitałem zagranicznym, która zasad- 
niczo różniła status podmiotów zagranicznych w odróżnieniu od państw Afryki czy innych kontynentów, gdzie wielkie korporacje czuły się znacznie lepiej niż w swoich krajach, wykorzystując swą wielką przewagę kapitałową i zależność rządów tych państw od mocarstw neokolonialnych. Inaczej było z Chińczykami i wynegocjowane zasady stosunków z firmami kapitalistycznymi były podstawowym warunkiem utrzymania suwerenności i niezależności Chińskiej Republiki Ludowej.

Nowością było także to, że rząd w Pekinie stworzył warunki do odrodzenia własnego, narodowego prywatnego kapitału, tworząc warunki dla ich konkurencji z firmami zagranicznymi. Na wsi nastąpił powrót do małych gospodarstw indywidualnych, rozwiązano komuny ludowe, jednocześnie część ziemi była uprawiana w dużych gospodarstwach państwowych i samorządowych, gospodarstwach typu join venture. Jednak nie zezwolono na odrodzenie gospodarstw obszarniczych. Wszystkie te reformy przyczyniły się do zwiększenia dynamiki rozwojowej chińskiej gospodarki. Obecnie, po ponad czterdziestu latach, Chiny wysunęły się na czołową pozycję gospodarczą w świecie i „depczą po piętach” gospodarce amerykańskiej. Jednak nadal wielkim problemem jest jej niska wydajność, około 4,5 razy mniejsza niż wydajność gospodarki amerykańskiej czy przedsiębiorstw innych wysoko rozwiniętych państw kapitalistycznych. Wskazuje to na nadal duże słabości gospodarki chińskiej i jest przedmiotem troski rządu chińskiego, którego plany rozwojowe do 2035 i 2049 r. przewidują zmniejszenie, a nawet likwidację tej niekorzystnej relacji.

O wielkich i wręcz epokowych zmianach gospodarczych i socjalnych ostatnich lat świadczą oficjalne dane, przedstawione przez rząd chiński z okazji 70-lecia powstania Chiń- 
skiej Republiki Ludowej. Z nędzy wyciągnięto ponad $700 \mathrm{mln}$ ludzi, ponad 400 mln osiąga średnie dochody, co roku przybywało średnio $10 \mathrm{mln}$ nowych miejsc pracy, głównie w przemyśle i usługach, a drugie tyle było modernizowanych. Co roku o około 1\% zwiększał się stopień urbanizacji, który w 2020 r. wynosił ponad 61\%. XIV Plan Pięcioletni na lata 2021-2025 przewiduje wzrost urbanizacji do 65\%. Roczna produkcja zbóż wynosi średnio około $650 \mathrm{mln}$ ton, nie licząc innych rodzajów żywności i jest to, jak się wydaje, maksimum wydajności, co można uzyskać z upraw w oparciu o generalnie rozdrobnioną gospodarkę rolną i ograniczenia maszynowo-technologiczne i chemiczne produkcji rolnej. Jakościowy wzrost produkcji rolnej jest możliwy w rezultacie zmiany dotychczasowej rozdrobnionej gospodarki, szczególnie na południu kraju. Barierą jest nadal wielkie przeludnienie wsi, gdzie mieszka około 550 mln ludzi, dla których własne, nawet małe gospodarstwo rolne jest podstawą uzyskania minimalnych dochodów na przeżycie. Generalnie w dalszym ciągu wieś jest rezerwuarem taniej siły roboczej, z której ponad 280 mln ludzi emigruje jako pracownicy sezonowi do szybko rozwijających się miast we wschodnich i centralnych rejonach kraju. Podejmują tam pracę często za najniższe stawki i zadowalają się niskimi standardami socjalnymi, np. nie dysponują oni prawem do stałego zamieszkania ("hukou”). Te wielomilionowe masy robotników sezonowych są jednym z kół zamachowych chińskiego cudu gospodarczego, chińskiej taniej produkcji oraz budownictwa miejskiego. Jest to poważna sprzeczność społeczna, problem nie tylko socjalno-ekonomiczny, także polityczno-klasowy i dowodzi głębokiego i pogłębiającego się rozwarstwienia społeczno-dochodowego obywateli, w szczególności między mieszkańcami miast i wsi, które wynoszą w dochodach jak 3:1. 
Innym następstwem sprzecznościowego rozwoju „socjalistycznej gospodarki rynkowej” jest odrodzenie się burżuazji narodowej, w tym masowego drobnomieszczaństwa, które dominuje w małej i średniej produkcji, ale przede wszystkim w usługach, w szczególności nowoczesnych, jak elektroniczna obsługa gospodarki, banków, komunikacji, turystyki, służby zdrowia, hotelarstwa, restauracji itd. Odrodziła się także wielka i średnia burżuazja narodowa. $\mathrm{Na}$ szczycie tej nowej klasy sytuuje się licząca już prawie 800 osób grupa potężnych miliarderów i licząca około $1 \mathrm{mln}$ grupa milionerów, którzy liczą swe bogactwa nie w juanach, lecz w dolarach i euro. Znaczna ich część od dawna mieszkała i mieszka w Hongkongu i Makao i w znacznym stopniu jest konsekwencją pokojowego włączenia tych byłych kolonii do Chińskiej Republiki Ludowej, co nieco zaciemnia statystyki. Temu rosnącemu rozwarstwieniu towarzyszy w życiu publicznym wielka korupcja, która ma nie tylko charakter finansowo-kryminalny, także polityczny. Co pewien czas władze publikują krótkie komunikaty o skazaniu na wysokie kary za korupcję osób z kręgów najwyższych stanowisk partyjnych i państwowych, co ma odstraszać kolejnych kandydatów ulegających tym procederom. Jest to problem narastający, ale jego źródła tkwią nie tyle w słabościach ludzkich charakterów, lecz w istocie gospodarki mieszanej, w której sektor kapitalistyczny staje się coraz silniejszy, kieruje się zyskiem i bardzo często nie respektuje ograniczeń prawnych, gdyż zysk jest głównym motorem aktywności biznesu.

Burżuazja narodowa, jak sama nazwa wskazuje, kieruje się interesem narodowym i KPCh poczynając od Deng Xiaopinga dopuściła do jej odrodzenia, licząc na to, że stanie się ona siłą konkurencyjną wobec kapitału zagranicznego, 
obcego, który inwestuje w Chinach na masową skalę, osiągając wręcz niebotyczne zyski. To jest ten epokowy haracz, który lud chiński płaci zagranicznemu kapitałowi za dostęp do nowoczesnej produkcji i technologii. Chiński narodowy kapitał prywatny, także kapitał Chińczyków - kapitalistów z zagranicy, w tym z Hongkongu, Makao, Tajwanu, a także z krajów zamorskich, głównie z USA (San Francisco), Kanady (Vancouver), Australii okazały się bardzo skutecznym instrumentem konkurencyjnym wobec w pełni obcych grup kapitałowych. Okazało się, że więzy chińskich wartości i cywilizacji są nadal silnym spoiwem i budują nowy patriotyzm Chińczyków z kontynentu i krajów zamorskich, nawet w sytuacji sprawowania rządów w ChRL przez partię komunistyczną, której ideały i wartości stały się im bliższe przez fakt wmontowania w ideologię KPCh niektórych postępowych wartości i zasad konfucjanizmu.

Chińska burżuazja narodowa otrzymała wielkie możliwości bogacenia się (co czasem prowadzi do groteskowych form publicznej demonstracji tego bogactwa przez nowych nuworyszów), ale ma ograniczone możliwości działania politycznego jako klasa społeczna. Przede wszystkim nie dysponuje ona własną partią polityczną, która mogłaby przekładać jej wielki potencjał ekonomiczny na państwowo-polityczny i wpływać na kształtowanie woli politycznej. Nie chce się ona angażować w kilku tzw. partiach demokratycznych (środowiskowych), które są reliktami historycznymi aktywności politycznej z okresu przedwojennego i sprzed 1949 r. ubiegłego wieku. Chińska nowa burżuazja ocenia je za zbyt skromne wobec ambicji nowych wielkich kapitalistów i będących w ich sejfach olbrzymich kapitałów. Większe możliwości dają temu silnemu i rosnącemu sektorowi gospodarczemu różne stowarzyszenia i kluby biznesowe 
różnych grup kapitałowych, które są także reprezentowane w Stałej Komisji Konsultacyjnej na szczeblu centralnym i w odpowiednich prowincjonalnych i lokalnych. Instytucje te są formami i organami działającego w Polsce Ludowej Frontu Jedności Narodu, w których dyskutowane są i ścierają się różne interesy ogólnonarodowe, klasowe, warstwowe, środowiskowe, lokalne. Oczywiście kierowniczą rolę w tym Froncie (Komisji Konsultacyjnej) pełni Komunistyczna Partia Chin, ale w obecnej sytuacji ekonomicznej musi ona bardziej respektować interesy wielkiego biznesu, tym bardziej, że od dwudziestu lat zezwoliła ona biznesmenom na ubieganie się o członkostwo w KPC, jeśli uznają oni linię partii, jej statut i politykę. Obecnie grupa ta w KPCh jest liczbowo większa niż robotnicy (o czym na następnych stronach artykułu) i można domniemywać, że ich wpływy polityczne są znacznie większe niż robotników. Jest to bez wątpienia wielka sprzeczność ideowo-polityczna, która rozmywa jedność ideowo-polityczną i ekonomiczno-finansową szeregów partii komunistycznej.

Zarysowana sytuacja polityczno-klasowa jest bardzo sprzecznościowa tak w stosunkach wewnętrznych, jak i zagranicznych. Kierownictwo KPCh musi prowadzić bardzo rozważną i delikatną politykę wobec licznych niebezpiecznych zagrożeń. Bardzo ważnym zabezpieczeniem wobec groźby kontrrewolucji i upadku socjalizmu w Chinach (podobnie jak w ZSRR i europejskich KDL-ach) jest pozostawienie strategicznych, wiodących gałęzi przemysłowych i infrastruktury gospodarczo-komunikacyjnej w rękach państw. Dotyczy to strategicznych gałęzi przemysłowych, przemysłu zbrojeniowego, energetycznego, bogactw naturalnych, własnością państwa jest ziemia, bogactwa naturalne, kopaliny, zasoby wodne, transport, komunikacja, środki 
masowej informacji, w tym prasa, radio telewizja, Internet poddany jest częściowej kontroli, szkolnictwo, szkoły wyższe, kultura. Czynione są próby obchodzenia ograniczeń, szczególnie w tych ostatnich dziedzinach, ale nie zmienia to ogólnego obrazu. System finansowo-bankowy należy do państwa lub znajduje się pod kontrolą banków państwowych. Ocenia się, że sektor państwowy obejmuje ok. 1/3 potencjału gospodarczego. Do niego należy doliczyć sektor społeczny na wsi, reprezentowany przez liczne spółdzielnie zaopatrzenia i zbytu, lokalną bankowość, co jest kontynuacją nie tylko niektórych wcześniejszych instytucji, ale także dużych tradycji gminnego władania ziemią i wspólnego gospodarowania lub samopomocy sąsiedzkiej. Ocenia się, że Centralny Bank Ludowy kontroluje bezpośrednio i pośrednio 95\% finansów i transakcji finansowych, w tym określania wartości juana do dolara i innych walut zagranicznych.

Innym ważnym aspektem socjalistycznej gospodarki rynkowej jest polityka zagraniczna ChRL. Od 1945 r. Chiny zdobyły status mocarstwa światowego, co formalnie gwarantowało stałe członkostwo w Radzie Bezpieczeństwa ONZ. USA godząc się na ten układ nie przewidywały, że w 1949 r. władzę w prawie całym kraju przejmie Komunistyczna Partia Chin i powstanie Chińska Republika Ludowa, która do 1975 r. nie była uznawana przez rząd USA , które blokowały jej prawo i w dalszym ciągu miejsce to było zajmowane przez przedstawiciela Republiki Chińskiej, której władza ograniczała się do Tajwanu. Obecnie sytuacja jest diametralnie inna. Niemal od pół wieku Chińska Republika Ludowa jest nie tylko formalnie, także faktycznie wielkim mocarstwem. Gospodarczo znajduje się w gronie wielkiej trójki (USA, ChRL, Unia Europejska), cieszy się wielkim autorytetem na arenie międzynarodowej. Jest państwem, 
które ma wielki wpływ na politykę nie tylko Azji, także całego świata, czego niektóre kręgi wielkiej burżuazji, głównie w USA, nie chcą przyznać, stosując wobec Chin pod różnymi pozorami embargo gospodarcze, sankcje, restrykcje i różne formy izolowania, a nawet nowej zimnej wojny, co jest zwiastunem nowych sprzeczności międzynarodowych.

Obecnie bez Chin nie można rozwiązać żadnego wielkiego problemu nie tylko w Azji, także na całym świecie. Chiny od lat prowadzą na arenie międzynarodowej pokojową politykę, a jako państwo socjalistyczne stanowią ustrojową alternatywę wobec państw kapitalistycznych i są ważnym podmiotem utrzymywania pokoju. Jako państwo rozwijające się starają się reprezentować interesy innych państw rozwijających się. Ważnym instrumentem tej polityki jest aktywizacja Chin w ramach ruchu państw niezaangażowanych oraz pomoc gospodarcza w ramach inicjatywy Nowych Jedwabnych Szlaków, obejmująca współpracę ze 130 państwami Afryki, Azji Południowo-Wschodniej, Ameryki Łacińskiej, a także Rosji i byłych socjalistycznych państw europejskich.

W tej sytuacji polityka zagraniczna Chin musi uwzględniać różne interesy i zagrożenia wewnętrzne oraz międzynarodowe, światowe, kontynentalne, regionalne, wojskowo-militarne, klasowe, narodowo-etniczne, gospodarczo-handlowe. Chińska Republika Ludowa stała się wielkim graczem w stosunkach międzynarodowych. W polityce międzynarodowej ścierają się różne, często bardzo sprzeczne interesy, głównie USA i innych wielkich mocarstw, na które nakładają się interesy państw i narodów mniejszych, organizacji międzynarodowych. Chiny są konsekwentnym rzecznikiem utrzymania pokoju na świecie, przede wszystkim w Azji i wokół własnych granic, często nawet za cenę rezygnacji i ustępstw z mniej- 
szych wartości i interesów wobec groźby wybuchu większego konfliktu wojennego. Główny cel chińskiej polityki zagranicznej to utrzymywanie jak najdłużej pokoju na świecie i możliwość korzystania ze styku z najbardziej rozwiniętymi gospodarkami świata. Trzeba mieć na uwadze, że współczesne Chiny są oficjalnie (według cen zachodnich) drugą gospodarką świata, ale produkcja na jednego mieszkańca i wydajność pracy są średnio 4,5 razy mniejsza niż w USA i najbardziej rozwiniętych państwach europejskich. Oznacza to, że ten nowy wielki potencjał przemysłowy i usługowy powstaje nie tyle za sprawą najnowocześniejszej produkcji i usług, ale dzięki pracy prawie miliardowej armii pracy Chińczyków. A więc ta sama jednostka PKB w USA, która wytwarzana jest przez 1 Amerykanina, wymaga pracy 4-5 Chińczyków. Jeszcze większe są różnice w rolnictwie i produkcji żywności, gdzie relacje te mają się nawet jak 1 do 30 . W tych relacjach widać z jednej strony jak wielki postęp uczynili Chińczycy w ramach gospodarki rynkowej, a jednocześnie wielki dystans do najbardziej rozwiniętych państw kapitalistycznych. Ich produkcja jest coraz lepsza a ceny towarów niskie oraz konkurencyjne i znajdują nabywców nie tylko w państwach biednych, ale także bogatych i drogich. Jak widać Chiny czeka jeszcze długa droga, mniej więcej trzydziestu lat, kiedy te potencjały produkcyjne i wydajność mają się wyrównać, jak przewidują prognozy, także w zakresie PKB na obywatela. Tak przynajmniej szacują nie tylko eksperci chińscy, także międzynarodowi, w tym amerykańscy. Zarysowana perspektywa rodzi cały szereg nowych sprzeczności, w szczególności między Chinami a USA, które nie zamierzają rezygnować ze swej hegemonii, a niektórzy przedstawiciele tego kierunku myślenia uważają, że temu niebezpieczeństwu może zażegnać nowa nie tylko zimna, ale nawet gorąca wojna z Chinami. 
Wszystko to powoduje, że Chiny w polityce zagranicznej prowadzą rozważną grę, nie angażują się w różnego rodzaju napięcia i konflikty. Jeśli nie mogą zatrzymać niekorzystnego biegu wydarzeń, wycofują się, jak np. z Libii w 2011 r. (z którą prowadziły bardzo intratne interesy), kiedy zaatakowały ją wojska NATO, w rezultacie zrujnowano postępowe państwo arabskie, a jej przywódca Muamar Kadaffi został bestialsko zamordowany. KPCh, choć jest partią komunistyczną o dużym autorytecie międzynarodowym, nie angażuje się w organizowanie nowego ośrodka międzynarodowego ruchu komunistycznego. Być może uważa, że jeszcze jest za wcześnie na taką inicjatywę, a jednocześnie takie kroki mogłyby ściągnąć na nią nowe ataki najbardziej antykomunistycznie zorientowanych ośrodków burżuazyjnych.

Tymczasem czołowe ośrodki burżuazyjne i państwa imperialistyczne nieustannie atakują Chińską Republikę Demokratyczną głównie z powodu odmienności ustrojowo-politycznej, widząc w niej obecnie nie tylko głównego konkurenta handlowo-gospodarczego, ale wroga klasowo-politycznego, którego chcą zniszczyć. Uważają one, że Chiny, niczym wcześniej Związek Radziecki i europejskie państwa demokracji ludowej, podążają ich drogą ku ustrojowej przepaści. Komunistyczna Partia Chin wyciągnęła jednak wnioski z klasowej klęski proletariatu ZSRR i KDL-ów, zmieniły taktykę, ale nie strategię budowy socjalizmu, a w dalszej perspektywie komunizmu. Bez wątpienia jest to fundamentalna przesłanka umocnienia ideowo-politycznego KPCh, jak również odrodzenia w niedalekiej przyszłości międzynarodowego ruchu komunistycznego i powstania nowych partii komunistycznych. Nie oznacza to, że siedzibą nowej Międzynarodówki Komunistycznej musi być Pekin 
czy Szanghaj. Z różnych powodów większe atuty mogłyby mieć np. czeska Praga albo Hawana na Kubie.

Wielką rolę w umacnianiu potencjału gospodarczego i handlowego Chińskiej Republiki Ludowej odgrywają Nowe Jedwabne Szlaki, wdrażane i rozwijane od ponad dziesięciu lat. Jest to koncepcja pokojowa zmierzająca do wyjścia z izolacji i okrążenia, narzucanych Chinom przez państwa imperialistyczne, mocniejszego styku gospodarki chińskiej z globalizującą się gospodarką, a przede wszystkim zmierza do silniejszego powiązania z gospodarką, finansami i polityką licznych biednych państw Afryki, Azji i Ameryki Łacińskiej. Podstawowym instrumentem tej polityki jest rosnąca wymiana handlowa na zasadach wzajemnych korzyści („win-win”). U podstaw tej koncepcji jest wielowiekowe doświadczenie kupców chińskich, rozwijających wymianę handlową z innymi częściami świata, ale także Komunistycznej Partii Chin z okresu walki o władzę w latach 30. i 40. XX w., kiedy KPCh odbudowała swe wpływy polityczne wśród biednego chłopstwa i wiejskiego proletariatu, w sytuacji wcześniejszej porażki w szeregach słabego miejskiego proletariatu. Wtedy Mao Zedong odbudował w rzeczywistości nowa partię komunistyczną nie tylko pod względem składu socjalno-zawodowego, ale także taktyki walki o władzę. Substratem członkowskim KPCh stał się proletariat wiejski i uboga ludność chłopska, które stanęły do walki z pozostałościami feudalizmu, kapitalizmem, obszarnictwem, o demokrację, a w dalszej kolejności o socjalizm. Nie bez powodu Mao Zedong był oskarżany przez ideologicznych przeciwników, że w rzeczywistości był on twórcą w Chinach tzw. socjalizmu agrarnego, przeprowadził rewolucję na wsi, która w późniejszych latach otoczyła miasta, obaliła rządy kompradorskiej burżuazji i rozpoczęła budowę podstaw so- 
cjalizmu. Te doświadczenia rewolucyjne znane były także w innych zacofanych państwach kolonialnych bądź postkolonialnych, np. na Kubie, Indochinach, Malajach, Nepalu, Nikaragui. Program takiej walki przyświecał Che Guevarze w Kolumbii i innych krajach Ameryki Łacińskiej. W poł. $\mathrm{XX}$ w. podchwycili go ludowi rewolucjoniści w krajach tzw. Czarnej Afryki np. w Kongu, Gwinei, Etiopii.

Nowe Jedwabne Szlaki to nie tylko inicjatywa handlowo-gospodarcza w kierunku postępowych państw Afryki i innych rejonów świata, wraz z nią idą nowe postępowe, ludowo-demokratyczne i socjalistyczne wartości i idee, nowe formy zachowań chińskich partnerów, bardziej postępowe stosunki społeczne, odróżniające je korzystnie od przedstawicieli wielkich korporacji kapitalistycznych, z reguły izolujących się od miejscowej ludności w luksusowych hotelach. Biorąc pod uwagę wielkość i masowość inicjatywy Nowych Jedwabnych Szlaków, obejmującej w różnych formach ok. 130 państw świata, można stwierdzić, że jest ona chińską koncepcją okrążania USA i burżuazyjnych metropolii przez postępowy, częściowo zrewolucjonizowany proletariat państw rozwijających się i jako taka jest klasową odpowiedzią postępowych sił świata wobec dążeń wielkiej światowej burżuazji do utrzymania jej panowania klasowego.

Podsumowując tę część rozważań o sprzecznościach chińskiej drogi do socjalizmu można stwierdzić, że komuniści chińscy idą własną drogą do socjalizmu i komunizmu. Koncepcja ta od zarania ruchu komunistycznego w Chinach wyznaczana była przez odmienną historię kraju, odmienność i specyfikę chińskiej kultury i cywilizacji, słabość rozwoju kapitalizmu i demokratycznych instytucji oraz liczne pozostałości stosunków późnofeudalnych, a na politykę nie tylko zagraniczną silny wpływ wywierały zagraniczne 
mocarstwa kolonialne. Przemysł był w początkowej fazie rozwoju, rodzimy chiński kapitał był słaby i całkowicie zależny od kapitałów zagranicznych. Proletariat miejski był nieliczny i skupiony w niektórych ośrodkach nadmorskich. Dużą rolę w powstaniu KPCh w lipcu 1921 r. odegrała Międzynarodówka Komunistyczna i doradcy radzieccy, którzy znając lepiej sytuację w Chinach chcieli powtórzyć „wariant rosyjski” w organizacji chińskiego proletariatu i jego walki o demokrację, socjalistyczną rewolucję i przeciwko panowaniu kapitalizmu. Jednakże sytuacja w Chinach była trudniejsza niż w przedrewolucyjnej Rosji, gdzie w dużych miastach powstawały lokowane przez obcy i rodzimy kapitał duże zakłady przemysłowe, zatrudniające liczne załogi robotnicze, które stanowiły potencjalną rewolucyjną bazę walki z kapitalistycznym wyzyskiem i o socjalizm, które zademonstrowały swą siłę pod kierownictwem bolszewików w rewolucji lutowej w 1905 r. i październikowej w 1917 r.

Komunistyczna Partia Chin w początkowym okresie była słaba, powstała z nielicznej grupki marksistów. Jej wpływy w rodzącym się dopiero proletariacie fabrycznym były znikome i powtórzenie wariantu rosyjskiego obalenia reakcyjnego rządu bardzo wątpliwe. Dodatkowo sytuację polityczną komplikowała rosnąca rola Kuomintangu, czyli ruchu zdominowanego przez narodową burżuazję, założonego prze Sun Yatsena i cieszącego się dużym poparciem warstw średnich. Kuomintang w pewnym okresie popierali także komuniści. Po śmierci Sun Yatsena w 1924 r. przywództwo w Kuomintangu zdobył generał Czang Kai-Szek, reprezentujący prawicowe skrzydło w Kuomintangu i siły wojskowe zorientowane zdecydowanie antykomunistycznie. Podjęta przez KPCh w 1927 r. próba zbrojnego powstania w Szanghaju i innych miastach Chin zakończyła się niepowodze- 
niem wobec słabości organizacji komunistycznych i słabego poparcia społecznego. Wojska Czang Kai-Szeka rozprawiły się z powstańcami i zmasakrowały komunistów, co na długie lata osłabiło ruch komunistyczny w Chinach. Dopiero za sprawą inicjatywy Mao Zedonga podjęta została kwestia odbudowy ruchu komunistycznego w oparciu jednak o nowy program, taktykę oraz strategię walki o władzę i o socjalizm.

Odbudowę nowej partii komunistycznej komplikowała zależność Chin od mocarstw zagranicznych i kapitału zagranicznego. Na wielkie sprzeczności wewnętrzne Chin nakładały się sprzeczności o charakterze międzynarodowym, zrodzone głównie przez agresywną kolonialną politykę mocarstw kolonialnych. Chiny są wielkim państwem o długiej liczącej kilka tysięcy lat historii, kulturze i cywilizacji. W ostatnich 150 latach doznawały one ze strony państw imperialistycznych i kolonialnych licznych upokorzeń i ucisku, poczynając od wojny opiumowej prowadzonej w połowie XIX w. przez Anglię, co skutkowało agresją terytorialną i oderwaniem od cesarskich Chin Hongkongu, Tsingtao i Tajwanu. Chiny nie były w stanie przeciwstawić się potędze i naciskom państw kolonialnych. Wymuszały one otwieranie stref specjalnych i narzucały inne formy zależności. Rosja carska szykowała się do aneksji Xinjiangu (Turkiestanu Wschodniego), Mongolii Zewnętrznej, Mandżurii. Anglicy dążyli do podporządkowania sobie Tybetu i środkowych Chin, Francuzi mieli duże apetyty na południowe prowincje Chin, czemu sprzyjało sąsiedztwo opanowanych przez nich Indochin. Pod koniec XIX w. do walki o wpływy w Chinach przystąpiły kajzerowskie Niemcy, okupując prowincję Shandong. Łakomym wzrokiem na Chiny patrzyła Japonia, która w latach 1904-1905 przystąpiła do wojny z Rosją o dominację w Korei i Mandżurii. 
Nowy etap walki o podział Chin rozpoczął się na początku lat 30., kiedy Japonia zaanektowała Mandżurię i stworzyła tam uzależnione od siebie marionetkowe Cesarstwo Mandżukuo z osadzonym na tronie ostatnim cesarzem Chin. Był to wyjątkowo brutalny dla Chin okres w ich historii, który przyniósł olbrzymie zniszczenia w kraju i oderwanie od Chin jednej z najbardziej rozwiniętej gospodarczo prowincji. W 1937 r. Japonia rozpoczęła dalszą agresję na Chiny, opanowując jej prowincje nadmorskie i centralne Chiny. Ocenia się, że w czasie tej wojny Chiny utraciły nie tylko olbrzymie terytoria, ekspansji japońskiej towarzyszyły liczne akty gwałtu, zniszczeń i barbarzyńskich strat. Ocenia się, że Chiny w rezultacie agresji Japonii straciły około $35 \mathrm{mln}$ ludzi.

Nowe kierownictwo KPCh wyciągnęło wnioski z nieudanego powstania i rozbicia partii przez Czang Kai-Szeka w miastach. W następstwie Mao odbudował od nowa KPCh w oparciu o biedne chłopstwo oraz wiejski proletariat. Partia z czasem odzyskiwała wpływy i stała się realną siłą walki z kapitalizmem, obszarnictwem, o demokrację i socjalizm, szczególnie po tzw. Długim Marszu w latach 1934-1935. Nowa strategia i taktyka walki przyniosła KPCh powodzenia także w nieustannej wojnie prowadzonej przeciwko okupantom japońskim, co umocniło autorytet KPCh w kategoriach narodowych. 1 października 1949 r. w Pekinie Mao Zedong proklamował powstanie Chińskiej Republiki Ludowej i od tego czasu Chiny rozpoczęły budowę podstaw socjalizmu i z czasem stały się nowym socjalistycznym mocarstwem, nie unikając na tej drodze błędów i wypaczeń, które skutecznie przezwyciężano.

W związku z tym należy odnieść się do różnic zdań, a nawet sprzeczności, które wystąpiły w relacjach między kierownictwem KPCh a Międzynarodówką Komunistyczną 
i jej doradcami, głównie radzieckimi, którzy zgodnie z zasadami Międzynarodówki mieli wpływ na treści programowe, strategię i taktykę KPCh, która w strukturze organizacyjnej MK była jej „sekcją”. W następstwie obowiązywała ją zasada centralizmu demokratycznego, podporządkowująca wszystkie partie komunistyczne kierownictwu MK w Moskwie i siłą rzeczy także kierownictwu WKP(b). Oznaczało to, że główne kierunki, zadania, ale i metody walki (taktyka) były określane przez kierownictwo $\mathrm{MK}$, co tworzyło centralizację działania. $Z$ drugiej strony wytworzyło warunki do odrywania się od realiów ekonomiczno-kulturowych i ideowo-politycznych poszczególnych państw i partii, w tym wypadku Komunistycznej Partii Chin.

Powstałe różnice zdań między Mao Zedongiem i nowym kierownictwem KPCh ochłodziło na pewien czas stosunki między KPCh a kierownictwem Międzynarodówki Komunistycznej, m.in. z powodu powstania w łonie chińskiego kierownictwa "frakcji promoskiewskiej” i „frakcji narodowej”, które zostały przezwyciężone w rezultacie nowej agresji japońskiej w 1937 r. i konieczności stworzenia wspólnego frontu sił antyjapońskich i patriotycznych. W wojnie z agresją japońską nieodzowna stała się pomoc materialna ze strony Międzynarodówki Komunistycznej, szczególnie wojskowa ze Związku Radzieckiego, co było możliwe po przeniesieniu głównej bazy KPCh do Jennanu na północy kraju. Te różnice zdań i sprzeczności między Komunistyczną Partią Chin a WKP (b) i później KPZR dawały o sobie znać po zwycięskiej wojnie w 1945 r. z Japonią, powstaniu Chin ludowych w 1949 r., a w szczególności pod koniec lat 50. XX w., kiedy rozeszły się drogi KPCh i KPZR i doszło do rozbicia wspólnoty państw socjalistycznych i międzynarodowego ruchu komunistycznego. W dalszych latach okazało się, że głównym 
beneficjentem tego upadku i rozbicia ruchu komunistycznego i robotniczego nie była ani KPZR, ani KPCh, lecz światowa burżuazja, kapitalizm i imperializm na czele z USA.

Spory ideowo-polityczne między obu partiami przechodziły w drugiej połowie XX w. różne koleje losów. Miały one głównie charakter ideowo-polityczny i obejmowały węzłowe kwestie strategii i taktyki międzynarodowego ruchu komunistycznego i robotniczego, dróg i metod rewolucyjnej walki, sojuszów klasowych, walki z kapitalizmem, imperializmem, kolonializmem, przeciwko wojnie (szczególnie atomowej) i o pokój. W kategoriach ideologicznych wystąpiła także kwestia walki z rewizjonizmem, reformizmem i oportunizmem, którym uległa znaczna część partii komunistycznych, przy czym niebezpieczeństwu temu ulegały nie tylko duże partie komunistyczne na Zachodzie, schodzące w wyniku różnych przyczyn z pozycji rewolucyjnych na pozycje oportunistyczno-socjaldemokratyczne i większość $\mathrm{z}$ nich traciła masowe poparcie klasy robotniczej, która także zmieniała się strukturalnie w następstwie rozwoju nowych przemysłowych sił wytwórczych, wdrażania zdobyczy rewolucji naukowo-technicznej, technotroniki, wdrażania efektów rozwoju społeczeństwa wiedzy.

Jednocześnie w Związku Radzieckim po śmierci Stalina w marcu 1953 r. w kierownictwie KPZR zwyciężyło skrzydło negacji kursu budowy socjalizmu, które pod hasłem krytyki kultu jednostki (Stalina), błędów i wypaczeń, deformacji, a nawet zbrodni stalinowskich skrycie przechodziło na pozycje erozji socjalizmu, stopniowego odchodzenia od ustroju socjalistycznego pod hasłami „więcej demokracji” i "powrotu do leninowskich zasad”. W miejsce internacjonalizmu proletariackiego nowe kierownictwo kierowało się głównie ochroną interesów wielkomocarstwowych Związku 
Radzieckiego, co w czasach M. Gorbaczowa doprowadziło do całkowitego upadku KPZR i ZSRR (1991 r.). N. Chruszczow zanegował klasowy charakter państwa radzieckiego i dalszej konieczności dyktatury proletariatu i lansował powstanie „państwa ogólnonarodowego". Podobnie stało się to udziałem partii komunistycznych i robotniczych (z nazwy) i państw demokracji ludowych w Europie, co z czasem doprowadziło do całkowitego upadku nie tylko wspólnoty państw socjalistycznych, także ZSRR, jego rozczłonkowania na republiki burżuazyjno-kapitalistyczne z najczęściej z reakcyjnymi reżimami politycznymi oraz rozpętało między nimi nowe wojny, m.in. na Kaukazie, Ukrainie. Światowa burżuazja i kapitał miały powody święcić triumfy, a Stany Zjednoczone ogłosiły się „światowym hegemonem” (policjantem) w nowym światowym porządku (new world order), co potwierdziły nowymi imperialistycznymi wojnami w Iraku, Afganistanie, Jugosławii, Syrii, Bliskim Wschodzie i innych rejonach świata.

Jednakże siły burżuazyjno-imperialistyczne nie były wszechmocne. Kontrrewolucja i światowy kapitalizm nie były w stanie obalić socjalizmu i demokracji ludowej w Chińskiej Republice Ludowej, KRLD, Wietnamie, Laosie i Kambodży, a także na Kubie, w których rządzące tam partie komunistyczne i narodowowyzwoleńcze przewidziały wcześniej grożące im niebezpieczeństwa międzynarodowe i wewnętrzne i skutecznie przeciwstawiły się próbom obalenia socjalizmu i demokracji ludowej. Największe znaczenie miało siłowe rozprawienie się z próbą puczu podjętego przez prokapitalistycznie nastrojonych studentów pekińskich na placu Tiananmen w Pekinie w czerwcu 1989 r. (popieranych przez część kierownictwa $\mathrm{KPCh}$ ), kiedy po trwających przez dwa miesiące dyskusjach i perswazjach nowe kierownictwo KPCh na czele 
z Deng Xiaopingiem uznało, że Chiny ludowe muszą iść dalej do socjalizmu własną drogą (drogą reform i socjalistycznej gospodarki rynkowej), których główne kierunki wyznaczone zostały w $1978 \mathrm{r}$.

Koncepcja ta była na pozór zaprzeczeniem dotychczasowej teorii i praktyki budowy socjalizmu w oparciu o scentralizowaną gospodarkę planową, która w rozwoju ZSRR i innych państw socjalistycznych przynosiła w pierwszych etapach duże raty wzrostu gospodarczego, ale w schyłkowym ich etapie okazała się hamulcem, a nawet szkodliwą w konfrontacji z przyspieszonym rozwojem ekonomik czołowych państw kapitalistycznych, które wstąpiły na drogę rewolucji naukowo-technicznej i mimo że nie wyeliminowały cyklicznych kryzysów, to znacznie je osłabiły, co było ważnym argumentem w ich zwycięskiej rywalizacji i konfrontacji ze Związkiem Radzieckim i realnym socjalizmem.

Deng Xiaoping i jego grupa uznali, że rynek nie musi być wrogi i szkodliwy dla socjalistycznej gospodarki, jeśli nie jest on jedynym mechanizmem regulującym współczesną ekonomię. Doświadczenia wielkiego kryzysu z lat 30. XX w. i sposoby wyjścia z niego dowodziły, że także państwa burżuazyjne wprowadzały pewne elementy planowania przez wielkie korporacje, a w skali państwowej przez mechanizmy sterowania politycznego instrumentami i mechanizmami interwencjonizmu państwowego, co teoretycznie opracował angielski ekonomista J.M. Keynes, twórca koncepcji kapitalizmu państwowego, co przy wychodzeniu z kryzysu na masową skalę wykorzystały Stany Zjednoczone w polityce F.D. Roosevelta - New Deal'u dla utrzymania liberalno-demokratycznego ustroju USA. Jeszcze dalej w tym kierunku poszły hitlerowskie Niemcy dla nie tylko przezwyciężenia skutków kryzysu, ale odbudowy potęgi niemieckiej w opar- 
ciu o totalitarny faszyzm i nazizm (4-letni tzw. plan Goeringa). W związku z tym należy przypomnieć, że wbrew obiegowym twierdzeniom Chińczycy nie znieśli w ogóle planowania gospodarczego. Nadal podstawą ich dalekosiężnego gospodarowania są 5-letnie plany rozwoju gospodarczo-społecznego, planowanie okresowe i dalekosiężne, np. do 2035 i 2049 r. Zmienili natomiast ich charakter z centralnie planowanej i kierowanej gospodarki na indykatywne (czynnikowe) planowanie i sterowanie gospodarką w kategoriach gałęziowych. Oznacza to, że w praktyce gospodarowania działają dwie podstawowe zasady: rynkowa, a jeśli ta zawodzi, interwencji organów socjalistycznego państwa.

Jak już wspomniano, socjalistyczna gospodarka rynkowa po ponad czterdziestu latach przyniosła wielkie rezultaty gospodarcze i socjalne, mierzone wielkimi wręcz historycznymi zmianami, które wysuwają Chińską Republikę Ludową na drugą, a nawet, jak dowodzą niektórzy eksperci, na pierwsze miejsce w świecie (pod względem wielkości PKB), co spędza sen z oczu możnym tego świata (głównie USA). Kierownictwo KPCh, poczynając od Deng Xiaopinga przez nowe kolejne ekipy przywódcze Jiang Zemina, $\mathrm{Hu}$ Jintao i aktualnie rządzącego Xi Jinpinga kierują Chinami od 44 lat i niewątpliwie odnotowują wielkie sukcesy w rozwoju gospodarczo-społecznym Chin i na arenie międzynarodowej, także we wznoszeniu nowoczesnej urbanistyki, infrastruktury komunikacyjnej i wyrównywania głębokich różnic ekonomicznych i kulturalnych między poszczególnymi opóźnionym prowincjami i regionami kraju. W polityce międzynarodowej Chińska Republika Ludowa liczy się jako wielkie postępowe, pokojowe, socjalistyczne światowe mocarstwo, zdobywające sobie coraz większy autorytet i poważanie szczególnie wśród biedniejszej ludności 
świata. W przeciwieństwie do kapitalistycznych i imperialistycznych Stanów Zjednoczonych, a także innych państw burżuazyjnych budują one bardziej egalitarne i równościowe społeczeństwo, oparte na teorii naukowego socjalizmu i pozytywnych doświadczeniach wcześniejszych państw socjalistycznych.

Rozwój ten i wielkie osiągnięcia nie oznaczają, że w Chinach nie ma sprzeczności, są i to coraz głębsze, w tym także odrodzone sprzeczności społeczno-klasowe. Obserwacja chińskiego życia gospodarczo-społecznego wskazuje, że rośnie rozwarstwienie społeczne, narastają i pogłębiają się sprzeczności klasowe. Mierzone współczynnikiem Gini’ego osiągnęły one w ostatnich szczególnie latach poziom sprzeczności, jak w USA, Brazylii $(0,47)$, nie mówiąc o Polsce $(0,33)$. Wspomniano o prawie 800 miliarderach, prawie milionowej grupie milionerów (liczących swe majątki nie w juanach, lecz w dolarach USA), która to klasa (wielkiej burżuazji) zagarnia ponad 50\% majątku narodowego. W tych wyliczeniach należy także uwzględnić średnią burżuazję i liczne drobnomieszczaństwo, które przyczyniają się do pogłębiania nie tylko majątkowych, także klasowo-ideowych podziałów. Kapitał, kapitalizm (także państwowy) odtwarza i multiplikuje warunki oraz stosunki kapitalistyczne. Co prawda w $1 / 3$ środki produkcji należą do sektora społecznego, ale tendencję wzrostową ma kapitał prywatny, dodatkowo wzmacniany przez korporacje zagraniczne, a także wsparcie ideowo-polityczne przez państwa i ośrodki burżuazyjne na świecie. Walka klasowa ma także charakter międzynarodowy. Chiny wpadły w koleiny głębokiego rozwarstwienia społeczno-klasowego i podstawowym pytaniem jest czy ma to trwały i umacniający się trend, prowadzący do całkowitego i oficjalnego przejścia do kapitalizmu, czy też są to niechciane koszty transforma- 
cji, dopuszczone i kontrolowane przez KPCh i w stosownym czasie nastąpi ich wyhamowanie, ograniczenie i powrót do egalitaryzmu na nowym poziomie rozwoju bogactwa społecznego i rozwoju nowoczesnych sił wytwórczych. Pytanie jest otwarte, jak na razie kontrrewolucja w Chinach trzymana jest $w$ ryzach, ale w nieprzewidywalnych zmianach sytuacji wewnętrznej i zagranicznej może się ona wymknąć spod kontroli i działać żywiołowo.

Innym aspektem zagadnienia jest fakt, że kapitał prywatny nie ma możliwości politycznego dyskontowania swej silnej potęgi gospodarczej ze względu na brak, a właściwie zakaz organizowania własnej partii politycznej. W Chińskiej Republice Ludowej funkcjonuje system wielopartyjny, oparty na zasadzie kierowniczej roli Komunistycznej Partii Chin. Poza KPCh działa też osiem innych partii środowiskowych, które działają w ramach koalicji stałej typu socjalistycznego, obowiązuje jedna lista wyborcza, a kolejność kandydatów określona jest przez Komisję Konsultacyjną (organ frontu narodowego) odpowiedniego szczebla. Chińska burżuazja nie ma możliwości organizowania się w partię typu kapitalistycznego, która rywalizowałaby w walce o władzę z KPCh, a przynależność do małych partii tzw. demokratycznych nie jest dla niej interesująca. Jeżeli biznesmeni chcą działać partyjnie, ubiegają się raczej o członkostwo w KPCh lub działają w Komisjach Konsultacyjnych. Nie oznacza to, że niektórzy z nich nie marzą skrycie o powstaniu partii opozycyjnej w stosunku do systemu socjalistycznego, o czym świadczą postacie i grupy opozycyjne, jak np. Liu Xiaobo, który lansował wprowadzenie systemu partyjnego jak w Hongkongu, Niemczech lub w USA. Ponadto chiński biznes znakomicie wykorzystuje dla realizacji swych legalnych, a często nielegalnych celów potężną korupcję. 
Wymienione sprzeczności gospodarcze, majątkowe, społeczno-polityczne i klasowe w Chinach osłabiają, a nawet podważają koncepcję równościowego socjalizmu w Chińskiej Republice Ludowej. Wydaje się, że istotę sprzeczności w tym okresie, który oficjalne dokumenty zjazdowe KPCh nazywają „wstępnym etapem socjalizmu”, oddaje okres przejściowy od kapitalizmu do socjalizmu, w którym władza polityczna należy do klasy robotniczej i ludu pracującego, ale ekonomicznie jest silny sektor burżuazyjno-kapitalistyczny, co tworzy podstawę dla ustrojowej hybrydy. W bazie jest nadal silny kapitalizm, w nadbudowie dominuje socjalizm, w następstwie występują silne sprzeczności klasowe we wszystkich sferach życia społecznego. Według Human Development Index Organizacji Narodów Zjednoczonych, prezentujący rozwarstwienie społeczne w 189 państwach świata w 2020 r. Chińska Republika Ludowa znalazła się na 85 miejscu, a więc pod koniec pierwszej połowy. Stawia to więc cały szereg pytań na temat równości i nierówności w socjalizmie o chińskiej specyfice. Zadziwiające jest, że w obecnych Chinach sprzeczność ta nie wyraża się w silnych antagonizmach, które w innych rejonach świata mogłyby prowadzić nawet do powstań i zbrojnych walk na ulicach. Zapewne jest to wyrazem polityki łagodzenia tych sprzeczności przez umiejętną politykę społeczną KPCh, a także konfucjanizm, m.in. zasadę harmonii społecznej.

Na większą uwagę zasługuje nowa wielka inicjatywa gospodarcza o znaczeniu nie tylko wewnętrznym, ale także międzynarodowym, jaka jest od ponad dziesięciu lat kwestia Nowych Jedwabnych Szlaków. Nowe szlaki są wielką szansą dla dalszego rozwoju Chin, jednocześnie otwierają liczne nowe sprzeczności w relacjach z głównymi państwami kapitalistycznymi. Nazwa nawiązuje do dawnych Jedwabnych 
Szlaków, które znane były od starożytności, kiedy karawany kupiecki podążały z Chin i do Chin uciążliwymi trasami przez góry, pustynie i stepy na zachód do krajów średniej Azji, Indii, Persji, Mezopotamii, wschodnich wybrzeży Morza Śródziemnego i do starożytnego Rzymu. Już od starożytności chińskie statki odkrywały szlaki morskie wzdłuż Oceanu Indyjskiego i docierały do dalekich wybrzeży Afryki i Europy. Karawany opuszczające Chiny podążały tzw. „szlakiem północnym" okalającym pustynię Gobi od północy lub południowym, znajdując dogodne przełęcze przez Pamir lub Karakorum, przechodziły do Azji Środkowej (Buchara, Samarkanda) lub do doliny Indusu i dalej drogą morską do portów perskich lub Mezopotamii, Egiptu. W późniejszym okresie powstawały także inne odnogi Jedwabnego Szlaku, m.in. do Rusi Kijowskiej od XVII w. z Rosją (Irkuck, Kiachta).

W późniejszych czasach, w szczególności ekspansji kolonialnej mocarstw europejskich, zakładano kolonie, np. Makao (Portugalia), Hongkong (Anglia). Francuscy kolonizatorzy rozszerzali swe wpływy przez Indochiny, a Rosja uzależniała i anektowała terytoria od Turkiestanu, poprzez Mongolię, Mandżurię i Daleki Wschód, w szczególności w rezultacie tzw. „nierównoprawnych traktatów”. Odrębne możliwości ekspansji kolonialnej dawały tzw. „strefy specjalne" w wielkich miastach, które były eksterytorialne i pełniły ważną rolę w osłabianiu gospodarczym i militarnym Chin. Powstał nawet tajny plan zawarty przez Rosję, Anglię i Francję w kwestii całkowitego podziału Chin i likwidacji Państwa Środka jako samodzielnego organizmu politycznego. W rezultacie uzależniania kolonialnego i wobec odkrycia nowych dróg lądowych i morskich rola dawnych Jedwabnych Szlaków faktycznie upadła, a handel zagraniczny Chin 
znalazł się w rękach spółek handlowych państw europejskich, a później także USA i Japonii.

Nowe możliwości w zakresie odnowy Jedwabnych Szlaków stworzył burzliwy rozwój gospodarki chińskiej w rezultacie polityki otwarcia i socjalistycznej gospodarki rynkowej. Na początku XXI w. stało się jasne, że Chiny przekształciły się w producenta najnowocześniejszych poszukiwanych towarów i dóbr nie tylko dla słabo sytuowanych gospodarczo i finansowo części świata, ale także dla wysoko rozwiniętych państw kapitalistycznych. Chińskie przedsiębiorstwa, jak i kapitału zagranicznego, wykorzystując tanią siłę roboczą i taniość surowców produkowały tanie i konkurencyjne dobra, przynoszące wielkie zyski zarówno firmom krajowym, jak i zagranicznym.

W tej sytuacji chińskie przedsiębiorstwa osiągały także olbrzymie zyski, zwiększone przez scentralizowaną w dużej części produkcję, jak i możliwości wywozu nie tylko towarów, ale także kapitałów. Chińczycy przypomnieli sobie o swoich dawnych Jedwabnych Szlakach. Nie chodziło jednak o powrót do starych, błądzących po pustyniach i górskich bezdrożach karawanach kupieckich. Dzięki zgromadzonym środkom byli w stanie projektować i budować nowe Jedwabne Szlaki, nowe trasy i środki transportu, komunikacji, linie kolejowe, autostrady, odpowiadające nowym możliwościom technicznym, rewolucji telekomunikacyjnej odpowiednio do epoki wiedzy. Uruchamiano i rozbudowywano stare i nowe szlaki drogowe, głównie na osi wschód-zachód, w mniejszym stopniu północ-południe. Unowocześniono transport kolejowy, powstawały i powstają nadal śmiałe połączenia kolejowe łączące najdalsze zakątki Chin (np. do stolicy Tybetu Lhasy), także drogi, autostrady, komunikację lotniczą wewnątrz kraju i z wszystkimi ważnymi ośrodkami 
gospodarczymi, finansowymi i politycznymi świata. Wybudowano nowe wielkie porty morskie o znaczeniu międzynarodowym, uruchomiono masowy transport morski i oceaniczny, a nawet wydzierżawiano na pięćdziesiąt lat całe porty, np. Pireus w Grecji, niezwykle ważne dla masowego transportu towarów i ludzi na kierunkach europejskich. Dla obsługi nowych szlaków niezbędna stała się rozbudowa i unowocześnienie komunikacji internetowej i satelitarnej oraz stworzenie niezależnych systemów łączności i komunikacji. Chiny stały się czołową potęgą handlową świata.

Nowe Jedwabne Szlaki są ważnym czynnikiem wychodzenia chińskiej gospodarki na zewnątrz, mają one kilka celów: 1. prezentowanie szerokiej oferty wyrobów chińskiej produkcji; 2. wiązanie słabszych gospodarczo państw, w szczególności państw rozwijających się w Afryce, Ameryce Łacińskiej, Azji Południowej, a także Rosji i państw Europy Środkowo-Wschodniej.

Za tą szeroką, obustronnie korzystną wymianą towarów i usług idzie także eksport idei poprzez myślących nie tylko biznesowo, ale także socjalistycznie Chińczyków, np. propagowanie w praktyce chińskich osiągnięć gospodarczych, nowoczesnej techniki, narzędzi pracy, środków produkcji i w kontaktach międzyludzkich. Jest to więc nie tylko zwykła wymiana handlowa, także pośrednie propagowanie socjalistycznej ideologii, szczególnie ważne dla ludności państw rozwijających się, ich elit, dostrzegających w Chinach nie tylko korzystnego partnera, także model społeczno-gospodarczy możliwy w tych państwach do naśladowania. Chińskie uniwersytety szeroko otwarły bramy dla studentów z państw rozwijających się.

Nowe Jedwabne Szlaki stworzyły cały szereg problemów w relacjach z państwami wysoko rozwiniętymi, w szczegól- 
ności USA, Wielkiej Brytanii, Francji, Niemiec, które odrodziły stare i rozwijają nowe sprzeczności międzynarodowe, w szczególności jest to problem ważny dla byłych państw kolonialnych i z tego powodu nie cieszą się one w byłych koloniach dobrą opinią. Inaczej jest z USA, ale także Stany nie mają dobrej marki ze względu na etykietę „nowego imperialisty" lub mocarstwa neokolonialnego, a także opinię patrzących z góry ekspertów, którzy zajmują najbardziej ekskluzywne hotele i nie chcą się „fraternizować” z „kolorowymi tubylcami”. Inaczej Chińczycy, którzy w kontaktach z państwami rozwijającymi przyjmują warunki socjalne podobne do krajowców, oferują bardzo tanie, korzystne kredyty i w zachowaniach osobistych wykazują dużą bezpośredniość i bezinteresowność, co przysparza im wiele sympatii i poparcia.

Stany Zjednoczone wykazują w tej rywalizacji swoją hegemoniczną pozycję, ponieważ ulegają Chińczykom pod względem pracowitości i odporności na gorsze warunki socjalne, próbuję nadrabiać środkami prawno-administracyjnymi i finansowymi, wywierają na młode państwa i ich elity naciski polityczne, finansowe, a nawet szantaż i groźbę wojny. Do standardów polityki USA należą międzynarodowe, a więc nakładane pod naciskiem USA przez ONZ lub inne organizacje sankcje, embargo, restrykcje, opłaty celne oraz środki politycznego nacisku, łącznie z groźbami i szantażem militarnym. Odnosi się to także do samych Chin i Rosji, dążąc do ich okrążenia wojskowego w oparciu o NATO i inne pakty wojskowe, wyścig zbrojeń i groźby, szantaż, jak to niedawno czynił prezydent D. Trump w stosunku do Koreańskiej Republiki Demokratycznej, że rozkaże ją zbombardować bombami atomowymi. Taka konfrontacyjna polityka USA była udziałem nie tylko Trumpa. Już przeszło dziesięć lat temu bardziej postępowy prezydent USA B. Obama 
ogłosił Azję jako kluczowy dla interesów USA kontynent świata, a Ocean Spokojny jako basen o życiowym znaczeniu dla interesów USA.

Kwestia ta nie jest tylko wyrazem bieżących interesów USA. Amerykanie już na początku XX w. dostrzegli wielkie strategiczne znaczenie Pacyfiku, stąd zajęli kluczowe dla militarnej kontroli Archipelag Hawajów i wkrótce inkorporowali go jako samodzielny stan do USA. Na Hawajach budowano jeszcze przed II wojną światową olbrzymi port wojenny i wielką bazę wojskową, głównie w Pearl Harbor, w której stacjonowała wielka flota wojenna, kontrolująca Pacyfik od Aleutów Alaski, poprzez Hawaje do Filipin, będących wtedy kolonią USA. Było to głównie skierowane przeciwko imperialnej Japonii, a także socjalistycznemu Związkowi Radzieckiemu. W grudniu 1941 r. Japonia zaatokowała marynarkę wojenną w Pearl Harbor, upatrując w niej główny hamulec przed jej zakusami imperialnymi w Azji Południowo-Wschodniej i weszła w stan wojny z USA do września $1945 \mathrm{r}$.

Na marginesie podajmy, że o ile USA ogłosiły, że Pacyfik jest „oceanem amerykańskim”, dodajmy, że Chiny zadeklarowały Morze Południowochińskie za swój akwen wewnętrzny i zamknięty. ChRL na swych mapach i wydawnictwach nie pozostawia co do tego wątpliwości. Wyznaczone przez nie granice biegną wzdłuż Wietnamu albo północnych brzegów Borneo i Malezji, następnie kierują się ku południowemu wschodowi i dochodzą do wód okalających Filipiny. Oczywiście w granicach Chin znajduje się także Tajwan, określany w Konstytucji ChRL jako „święta ziemia Chin”. Na Morzu Południowochińskim armia chińska nieustannie umacnia swe bazy morskie, rozbudowuje wyspy dla celów militarnych i gospodarczych, gdyż pod szelfem kontynentalnym 
znajdują się wielkie bogactwa naturalne, w tym duże zasoby ropy naftowej i gazu. Jest to bez wątpienia wielki problem sprzecznościowy dzielący politykę Chińskiej Republiki Ludowej i głównie Stanów Zjednoczonych.

Kwestia Nowych Jedwabnych Szlaków jest postrzegana przez USA nie tylko jako gospodarczo-handlowa, ale także jako wojskowo-obronna. H. Kissinger już w 2014 r. na konferencji bezpieczeństwa w Monachium powiedział: „Sytuacja w Azji przypomina coraz bardziej Europę pod koniec XIX stulecia i nie można wykluczyć zbrojnego konfliktu”3. Jeszcze mocniej wyraził to gen. Ben Hodges (najwyższy dowódca Sił Zbrojnych USA w Europie), który stwierdził w 2018 roku, że „za 15 lat będziemy [USA - przyp. Z.W.] mieli wojnę z Chinami" ${ }^{4}$. Nie tak dawno (3 lutego 2021 r.) potwierdził tę prognozę admirał Charles Richard - szef strategicznego dowództwa USA w magazynie „USA Naval Institute”. Jego zdaniem Chiny demonstrują „agresywną” siłę gospodarczą i militarną, co dowodzi, że w przewidywanej przyszłości nie można wykluczyć nuklearnego konfliktu z NATO („nuclear employment is very possibility”). Wnioski takie wynikają także z dokumentu „NATO 2030”, powstałego pod kierownictwem sekretarza generalnego NATO Jensa Stoltenberga. Kwestia nie jest już tylko rozwijana w planach akcji wojennych przeciwko Rosji z państw bałtyckich, ale chodzi o Chiny, gdyż obecnie „wróg znajduje się nie tylko w bezpośrednim sąsiedztwie, ale także w rejonie Indo-Pacyfiku". Potwierdza to tezę, że obecnie w opinii amerykańskich ośrodków władzy głównym konkurentem, rywalem i wrogiem USA jest Chińska Republika Ludowa.

3 Cyt. za: „Unsere Zeit”, Essen, 2.04.2021.

4 Cyt. za: R. Homann, „Unsere Zeit”, Essen, 19.02.2021. 
Innym dowodem tego myślenia jest dokument strategiczny rządu USA z grudnia 2017 r., w którym czytamy: „Chiny i Rosja dążą do wyeliminowania amerykańskiej siły, jej wpływu i jej interesów i usiłują pogrzebać amerykańskie bezpieczeństwo i pomyślność (...) Naszym zadaniem jest zastopowanie tych dążeń, które utrzyma militarną przewagę USA (...) Będziemy umacniać nasze pozycje wszelkimi państwowymi środkami, ażeby poszczególne regiony świata nie zostały zdominowane przez inną siłę" ${ }^{5}$. W ostatnich latach w USA wiele uwagi poświęca się chińskiej polityce, co jest popierane przez inne koła zachodniego imperializmu i co oznacza wzrost aktywności antychińskich sił w Hongkongu i Makao, które choć są specjalnymi autonomicznymi regionami, to pozostają integralnymi częściami Chińskiej Republiki Ludowej. Na Tajwanie następuje wzrost uzbrojenia jego armii, a także umacnia się tendencje „niepodległościowe” wyspy, co godzi w uznaną od dawna zasadę, że Chiny są jedne i jednolite. Wykorzystuje się także rzekomy ucisk mniejszości narodowych w Tybecie, a obecnie szczególnie Ujgurów w Xinjiangu, by podkopać zaufanie ich obywateli do rządu ludowego w Pekinie i Komunistycznej Partii Chin. Udziela się poparcia „rządom” Tybetu i Xinjiangu na uchodźstwie, co umacnia nieprzyjazną politykę USA i innych ośrodków burżuazyjnych wobec Chińskiej Republiki Ludowej. Jest to także bardzo społecznościowa sytuacja w globalnej polityce międzynarodowej.

Chińska Republika Ludowa należy do największych państw świata, jej powierzchnia to ponad $9 \mathrm{mln} \mathrm{km}^{2}$, zamieszkiwania przez prawie 1,4 mld ludności, w tym $92 \%$ stanowią Chińczycy i $8 \%$ liczące ponad 50 mniejszości na-

5 Cyt. za: ibidem. 
rodowe i etniczne, z których pięć zorganizowanych jest w autonomiczne okręgi narodowe (Tybet, Ujgurski - Xinjiang, Mongolski, Hui i Guangxi) ponadto liczne prefektury i mniejsze jednostki podziału terytorialnego korzystające także z autonomii etnicznej. Specjalny status autonomiczny posiadają Hongkong i Makao. Integralną częścią Chin jest także Tajwan (Republika Chińska) faktycznie okupowany przez USA, pełniący strategiczną rolę w destabilizacji bezpieczeństwa w tym rejonie Azji i będący jednym z fundamentów amerykańskiej polityki w tej części Pacyfiku. Terytorium spornym między Chinami i Indiami jest duży obszar około 180 tys. km² w Himalajach, przyłączony do ChRL w rezultacie konfliktu wojennego obu państw w latach 60. XX w. Chińska Republika Ludowa ma prawnie uregulowane granice (poza wspomnianymi wyjątkami) i prowadzi pokojową politykę oraz utrzymuje dobrosąsiedzkie stosunki z bliskimi państwami. Granice państwa liczą wiele tysięcy kilometrów, ich kontrola i wojskowo-celna ochrona wymagają dużej armii wojsk pogranicznych i wielkiej ilości środków materialnych, główną siłą obronną jest Chińska Armia Ludowo-Wyzwoleńcza. ChRL stale umacnia potencjał wojskowo-militarny nie tylko w rejonach pogranicznych, sytuuje także olbrzymie inwestycje w budownictwo nowych linii kolejowych, autostrad dróg i połączeń lotniczych, które sprzyjają nie tylko wzmocnieniu obronności przygranicznych okręgów i prowincji, także ich rozwojowi gospodarczemu i społecznemu.

Szczególne znaczenie mają granice morskie liczące 18 tys. km i rozciągające się na północy od Morza Żółtego do Morza Południowochińskiego na południu. Prowincje nadmorskie są gęsto zasiedlone. Znajdują się tam dobrze rozwinięte ośrodki przemysłowe i wielkie porty, które mają strategiczne znaczenie gospodarcze dla państwa i są swoistą piętą Achil- 
lesa bezpieczeństwa chińskiego. Dotyczy to także mocno rozwijających się prowincji centralnych Chin. Natomiast prowincje zachodnie i północne, górzyste pustynne i stepowe są słabiej rozwinięte, ale mają także duże znaczenie strategiczno-wojskowe. Chiński rząd poświęca wiele uwagi i środków w rozwój nie tylko lotnictwa wojskowego i rakietowego, ale także marynarki wojennej, jako szczególnie ważnej dla modernizacji i nowej struktury organizacyjno-obronnej Chińskiej Armii Ludowo-Wyzwoleńczej. O chińskiej strategii obronnej można więcej powiedzieć w oparciu o oficjalny dokument pt. „Biała Księga strategii wojskowej Chin 2015”, jak i jej zaktualizowanej wersji z lipca 2019 r. („Chińska obrona kraju w nowej epoce”). Czytamy w niej: „Międzynarodowa strategiczna sytuacja wymaga obecnie istotnych zmian. Świat współczesny określony jest przez szybko następujące zmiany, które nie miały jak dotychczas możliwości wystąpić. Świat znajduje się na przełomie. W tym wielobiegunowym świecie sąsiadują pokój, rozwój i współpraca jako korzystne trendy epoki. Tym niemniej występują też czynniki destabilizujące, które szkodzą bezpieczeństwu międzynarodowemu. Strategiczny wyścig umacnia się, USA zmieniły strategię i realizują politykę unilateralną, którą wyznaczają na nowo intensywny wyścig i rywalizacja między głównymi państwami. Podnoszoną one wydatki na zbrojenia, umacniają potencjał broni atomowej i budują nowe systemy obrony terytorialnej i obrony antyrakietowej"6. Polityka ta jest bardzo niebezpieczna dla światowego pokoju i może powodować nowe konflikty wojenne na Dalekim Wschodzie. Jest to także bardzo sprzecznościowy aspekt stosunków międzynarodowych Chińskiej Republiki Ludowej.

6 Cyt za: „Unsere Zeit”, 2.04.2021. 
Chiny są jednym z największych państw świata o stale rosnącym potencjale gospodarczym i wojskowo-obronnym. Należy do grona wielkich mocarstw, co gwarantuje stałe członkostwo w Radzie Bezpieczeństwa, ale nie tylko ten fakt dokumentuje ich mocarstwowość. Ze względu na stałe zagrożenie ze strony państw imperialistycznych Chiny muszą przeznaczać znaczne środki na wydatki obronne odpowiednio do swego dochodu. Pod tym względem wysunęły się na drugą pozycję na świecie. Według różnych źródeł wydają one rocznie od 200 do 260 mld dol. Ta ostatnia liczba potwierdzona jest przez Sztokholmski Instytut Pokoju (SIPRI) za 2020 r. W tym czasie USA wydawały od 732 do podwyższonych wydatków w ostatnim roku prezydentury D. Trumpa (2020 r.) do 758 mld dol. Oznacza to, że udział wydatków na zbrojenia i obronę w USA wynosił 3,4\% PKB, a chińskiego 1,9\%. Jednocześnie należy podkreślić, że Stany Zjednoczone są tylko częścią (co prawda najważniejszą) międzynarodowego systemu obronnego, którego głównym instrumentem jest Pakt Północnoatlantycki, który razem z USA przeznacza na zbrojenia ok. 1,3 bln dol. rocznie. W odróżnieniu od USA chińska strategia obronna ma charakter defensywny i z tego powodu wydatki na obronę nie muszą być tak wysokie, jak w państwach imperialistycznych. Chińska Republika Ludowa od początku prowadzi politykę pokojową i legło to u podstaw jej polityki międzynarodowej, sformułowanej w pięciu zasadach Konferencji w Bandungu w $1955 \mathrm{r}$.

Ze względu na stałe zagrożenie ze strony państw imperialistycznych ludowe Chiny systematycznie modernizują armię i jej wszystkie rodzaje wojsk w celach obronnych. Od 1964 r. dysponują także bronią atomową, przy czym mają najmniejszą liczbę głowic atomowych wśród mocarstw 
i uroczyście zobowiązały się, że nigdy jej nie użyją pierwsi i to tylko w celach obronnych. Ostatnio dużo uwagi i wydatków poświęcają elektronicznym systemom dowodzenia oraz opanowania obrony w cyberprzestrzeni i kosmosie, a także zastosowania komputerów kwantowych. Głównym mocarstwem, które wymusza wzrost wydatków na zbrojenia Chin jest imperialistyczna polityka i kompleks militarno-wojskowy USA. Koła rządzące w Stanach zdają sobie sprawę ze słabnącej gospodarki amerykańskiej, a także coraz mniejszej atrakcyjności american way of life nie tylko wewnątrz kraju, także wśród narodów świata. Dlatego za wszelką cenę pragną utrzymać swą hegemonię w oparciu o środki militarne.

Siły zbrojne USA są w stanie prowadzić wojnę globalną, a więc we wszystkich rejonach świata i są ważnym elementem ich polityki dominacji w świecie. Dysponują one wszystkimi najnowocześniejszymi rodzajami wojsk i uzbrojenia. Poza własnym terytorium i uzależnionych państw sojuszniczych mają one 750 baz militarnych we wszystkich rejonach świata. Dla porównania Chińska Republika Ludowa dysponuje tylko jedną bazą w Dżibuti w Rogu Afryki, utrzymywaną nie tyle z powodów wojskowych, co ze względu na plagę korsarstwa i zagrożenia bezpieczeństwa dróg morskich z Oceanu Indyjskiego przez Morze Czerwone i Kanał Sueski do Morza Śródziemnego. W 2012 r. chińska marynarka wojenna liczyła 335 różnego rodzaju okrętów wojennych, pod względem ilości flota ta wyprzedza flotę USA, liczącą 291 jednostek, ale całkowicie inna jest struktura militarno-bojowa tej floty, np. USA dysponują szesnastoma lotniskowcami, Chiny tylko jednym. Chińska strategia zakłada obronny charakter armii, floty i obrony granic, dlatego stara się umacniać obronę wybrzeży. W tym celu 
poświęca dużo uwagi umacnianiu punktów obronnych na wyspach Morza Południowochińskiego ${ }^{7}$.

Chińska Republika Ludowa dysponuje od 1964 r. bronią atomową, opanowała także produkcję broni wodorowej, głównie w oparciu o własne badania, kadry i technologię. Dążenie do opanowania broni atomowej było podyktowane chęcią zademonstrowania, że ChRL jest nie tylko de iure wielkim mocarstwem, ale także dysponuje odpowiednim potencjałem wojskowo-obronnym, w którym broń atomowa była militarnym certyfikatem wielkomocarstwowości. Obecnie Chiny dysponuj 332 głowicami atomowymi i w porównaniu z USA czy nawet z Rosją jest to wielokrotnie mniejszy potencjał, jednak wystarczający jako odstraszająca broń masowego rażenia - dla celów obronnych. W 2019 r. na czterech okrętach podwodnych o napędzie atomowym było zainstalowanych dwanaście głowic atomowych, jak i 320 głowic na rakietach międzykontynentalnych i średniego zasięgu. W tym czasie USA dysponowały ogółem 5800 głowicami atomowymi, a więc 16 razy więcej.

Modernizowane jest chińskie lotnictwo wojskowe, np. opanowano technikę budowy wielkich samolotów transportowych oraz ich tankowania w powietrzu. Modernizowane są bojowe śmigłowce a także nowe samoloty bojowe typu Chengdu J-20. Rozwija się produkcja dronów komunikacyjnych, obserwacyjnych i bojowych. Opanowano produkcję najnowocześniejszych samolotów bojowych i transportowych i Chiny znalazły się w gronie takich państw, jak USA i Rosja. Rekordem jest opanowanie produkcji największego samolotu nawodnego, który jest najbardziej skutecznym środkiem komunikacyjnym i transportowym między wyspa-

7 Dane za: R. Homann, op.cit. 
mi Morza Południowochińskiego. Hitem w 2020 r. stało się wyprodukowanie nowego bombowca, który osiągał przelot bez lądowania na odległość $8500 \mathrm{~km}$. Chińska armia coraz więcej uwagi poświęca programowi opanowania kosmosu, chodzi nie tylko o sztuczne satelity, ale także eksplorację Księżyca i Marsa, co zawiera w sobie także możliwości zapewnienia bezpieczeństwa w przestrzeni kosmicznej.

Analiza chińskiej polityki obronnej dowodzi, że ChRL dysponuje wystarczającym potencjałem wojskowym, zapewniającym jej bezpieczeństwo oraz pomyślnie rozwiązywać tę sprzeczność międzynarodową. Jednocześnie nie daje się wciągnąć w obłędny wyścig zbrojeń, który okazał się pułapką dla Związku Radzieckiego. Chiny zwiększają stopień obronności różnymi inicjatywami pokojowymi, kooperacją gospodarczą z państwami azjatyckimi i rejonu Pacyfiku, Szanghajską Organizacją Współpracy, w ramach BRICS, a także w ramach układów dwustronnych. Chiny od lat prowadzą politykę pokojowego współistnienia z innymi państwami, w tym także z USA i innymi państwami należącymi do NATO i innych paktów wojskowych, co nie jest to łatwe, mając na uwadze imperialne cele przyświecające tym państwom oraz ich podwójne standardy. Jako przykład podać można ostatni wzrost napięcia w stosunkach między Chinami a USA w rejonie Morza Południowochińskiego, w którego rejon prezydent J. Biden skierował lotniskowiec „T. Roosevelt” wraz z flotą towarzyszących mu okrętów wojennych. Wzorem poprzednich tego rodzaju akcji administracja waszyngtońska wpłynęła na przyłączenie się do niej jednostek innych państw NATO, a także prezydent Biden rozmawiał na ten temat z premierami Australii, Nowej Zelandii, Japonii, Indii. Z informacji prasy światowej wiemy, że gotowość w tej akcji wyraził brytyjski premier B. John- 
son, prezydent Francji E. Macron, a w najmniejszym stopniu kanclerz Niemiec A. Merkel, która nie chce narazić się Chińczykom ze względu na bardzo korzystne kontrakty handlowe z ChRL (rocznie ok. 200 mld dol.) Wydaje się, że bezpośrednią przyczyną tego napięcia jest głęboki deficyt handlowy USA z Chinami, sięgający ponad $500 \mathrm{mld}$ dol. rocznie i określenie Chin przez b. prezydenta D. Trumpa jako głównego przeciwnika USA i rozpoczęcia z nimi nowej zimnej wojny handlowej. Pod tym względem dalekowschodnia polityka J. Bidena nie różni się od polityki b. prezydenta USA. Natomiast więcej, prezydent Biden uruchamiając nową demonstrację wojskową w rejonie Morza Południowochińskiego skorzystał z projektu akcji przygotowanego przez sztab wojskowy D.T rumpa.

W związku z tym ChRL musi podejmować odpowiednie kroki, by chronić swe interesy w pobliżu swych granic. Siła Chin zawiera się nie tylko w możliwościach obronnych armii, ale przede wszystkim w głębokim patriotyzmie i zakorzenieniu armii w społeczeństwie chińskim, w jej ludowowyzwoleńczych tradycjach, w jej zaufaniu do polityki Komunistycznej Partii Chin i jej kierownictwa państwowego, ich gospodarczych i ideowo-politycznych osiągnięciach, jak i pokojowej polityce międzynarodowej. Wielkim atutem i zaletą obecnego kierownictwa chińskiego jest prawidłowe rozpoznanie powstających zagrożeń i sprzeczności międzynarodowych oraz określenie sił postępowych i wstecznych, budowanie korzystnej współpracy z pierwszymi i umiejętne rozgrywanie sprzeczności z drugimi bez uciekania się do wojny, w ramach pokojowego współistnienia. Jak dotychczas polityka ta zapobiegła powstaniu zjednoczonego, jednolitego bloku antychińskiego pod kierunkiem głównych państw imperialistycznych. Chiny nie chcą wojny i pragną żyć w po- 
koju, ale w sytuacji agresji są dobrze przygotowane do jej odparcia. W związku z tym można stwierdzić, że aktualnie, a także w przewidywalnej przyszłości Chińskiej Republice Ludowej nie zagraża bezpośrednie niebezpieczeństwo wojny. W polityce międzynarodowej Chiny od dawna opierają się o pięć zasad pokojowego współistnienia, mających na celu zbudowanie „wspólnoty losów ludzkości”, co zostało rozwinięte w podstawowym dokumencie XIX Zjazdu KPCh, który odbył się w dniach 18-24 października 2017 r. Stwierdza się w nim m.in., że żadne państwo na świecie nie jest obecnie w stanie zapewnić własnego bezpieczeństwa w izolacji od innych państw. Pokój jest możliwy, niebezpieczeństwo wojny można odeprzeć i świat może być bezpieczny, czysty i piękny. Chiny nikomu nie zagrażają, prowadzą pokojową i defensywną politykę, z ziemi chińskiej nigdy nie wyjdzie ekspansja i hegemonia.

W podsumowaniu tej części możemy stwierdzić, że chińska rewolucja i chińska droga do socjalizmu różniła się od wcześniejszych form rewolucyjnych w Komunie Paryskiej i w Rosji, a później w Związku Radzieckim. Bardziej nawiązywała do doświadczeń innych państw socjalistycznych, określanych jako państwa demokracji ludowej. Jednocześnie Komunistyczna Partia Chin wydała zdecydowaną walkę burżuazji oraz obszarnikom i pozostałościom Chin cesarskich, ale nie mogła i nie chciała odejść od wielkich historycznych zdobyczy chińskiej cywilizacji, określanej przez K. Marksa w poł. XIX w. jako „azjatycki typ produkcji”.

Szczególnie daleko idące różnice w budowie socjalizmu w Chinach nastąpiły w konsekwencji objęcia przywództwa w KPCh przez Deng Xiaopinga i jego kontynuatorów, wdrożenia reform gospodarczych, częściowego ożywienia rynku i szerokiego otwarcia się Chin na kooperację z wiel- 
kim kapitałem zagranicznym przy zachowaniu kontroli politycznej, finansowej i gospodarczej Chińskiej Republiki Ludowej. Otwarło to nowe wielkie możliwości rozwoju kraju, modernizacji gospodarki, a jednocześnie zrodziło cały szereg nowych sprzeczności, w tym klasowych. Kwestie te podzieliły w znacznym stopniu Komunistyczną Partię Chin i międzynarodowy ruch komunistyczny, m.in. zarzuca się KPCh, że odchodzi od socjalizmu i ideałów socjalistycznych i ulega kontrrewolucji.

Wydaje się, że krytyka ta nie jest w pełni uzasadniona. Zagrożenia na pewno występują, ale KPCh kontroluje sytuację politycznie, ekonomicznie i finansowo i jak dotychczas trzyma kontrrewolucję w ryzach. Na oryginalność chińskiej drogi do socjalizmu wpływa sinizacja marksizmu i włączenie do ideologii KPCh postępowych treści i zasad konfucjanizmu, co przyczyniło się do umocnienia zwartości chińskiego ludu i realizacji budowy socjalizmu o chińskiej specyfice, ale przyszłościowo ogranicza i izoluje tę koncepcję do kręgu chińskiej cywilizacji i stawia pod znakiem zapytania uniwersalność „chińskiego marksizmu”, który znalazł dotychczasowe rozwinięcie w maoizmie, dengizmie, Zasadzie Trzech Reprezentacji i myśli Xi Jinpinga. Wydaje się, że bardziej klarownie na te teoretyczne i w części ideowo-polityczne kontrowersje odpowiada marksistowska teoria i dialektyka okresu przejściowego od kapitalizmu do socjalizmu.

\section{Podstawowe sprzeczności socjalistycznej gospodarki rynkowej Chin w opinii jej krytyków}

Jak wspomniano wcześniej, nowa polityka gospodarczo-społeczna KPCh, realizowana już od ponad czterdziestu lat, jest atakowana głównie przez wielkie ośrodki burżuazyjno-ka- 
pitalistyczne z pozycji antysocjalistycznych i antykomunistycznych. Chińska Republika Ludowa jest nieustannym celem tych ataków i agresji ideowo-politycznej jako „państwo komunistyczne” i „dyktatura łamiąca podstawowe prawa człowieka". Podejmowane są nieustanne próby destabilizacji wewnętrznej ChRL przez aktywizację antyludowych i antysocjalistycznych sił, demonstracji, a nawet powstań na tle etnicznym. Nieustannie wykorzystuje się Tajwan (uznany na arenie międzynarodowej jako nieodłączna część Chin) do antypekińskiej polityki, co m.in. znajduje wyraz w ogłaszaniu ponownie jego „niepodległości” i nowych zbrojeniach. Odrębne formy protestów podejmowane są w Hongkongu i Makao, będące integralnymi częściami ChRL i korzystającymi ze specjalnych warunków autonomii. Od lat ośrodki burżuazyjne udzielają schronienia i poparcia dysydentom chińskim, a w szczególności popierają działalność „rządów” Tybetu i Xinjiangu na uchodźstwie.

Kwestie są także przedmiotem kontrowersji w międzynarodowym ruchu komunistycznym. Niektóre partie krytycznie odnoszą się do chińskiej koncepcji gospodarki rynkowej i uważają, że jest to zdrada podstawowych wartości i zasad ideologii komunistycznej, która ostatecznie doprowadzi do upadku socjalizmu w Chinach. Poglądy takie wyrażają np. działacze Komunistycznej Partii Grecji, Komunistycznej Partii Niemiec (KPD), a także innych partii. Ostatnio na ten temat ukazał się obszerny artykuł Juergena Gepperta ${ }^{8}$.

Wymieniony artykuł i jego treści wydają się najbardziej klarowną i konsekwentną krytyką koncepcji socjalizmu z chińską specyfiką, a w szczególności socjalistycznej gospodarki rynkowej. Autor wychodzi od analizy funkcji państwa.

8 J. Geppert, op.cit., s. 43-85. 
Definiuje on rynek jako część składową różnych sposobów produkcji, zależnych od stosunków produkcji. Rynek w stosunkach kapitalistycznych jest wykorzystywany przez kapitał w oparciu o kapitalistyczne stosunki własności. W socjalizmie rynek bazuje na gruncie socjalistycznej gospodarki planowej, której źródłem jest społeczna własność środków produkcji. Dlatego podział zasobów społecznych jest określany przez państwowe plany gospodarcze i nie są one tylko zależne od podaży i popytu na rynku.

W analizach ekonomistów burżuazyjnych rynek i gospodarka rynkowa są centralnymi kategoriami teorii ekonomicznej. Są one wzajemnie powiązane z własnością środków produkcji, możliwościami działania w procesach produkcji, osiągania zysków i ich podziałów, mechanizmem kształtowania cen, wymiany wewnętrznej oraz zagranicznej i ostatecznie cen rynkowych. Burżuazyjni ekonomiści posługują się określeniem „socjalistyczna gospodarka rynkowa” lub "socjalistyczna gospodarka rynkowa o chińskiej specyfice", nawiązują oni wprost do chińskiej praktyki gospodarczo-ustrojowej, która wdrożona została przez Deng Xiaopinga w 1978 r. i znalazła później swój teoretyczny i prawny wyraz w Konstytucji Chińskiej Republiki Ludowej. Jej podstawowymi cechami była legalizacja działalności prywatnych przedsiębiorstw produkcyjnych, usługowych, a także otwarcie się kraju i gospodarki na zakładanie przez kapitał zagraniczny swych przedsiębiorstw. W dalszej części reform następowała prywatyzacja sektora państwowego poprzez liberalizację handlu i cen dóbr konsumpcyjnych. W 2004 r. połowa pozostałych jeszcze przedsiębiorstw państwowych zmieniła sposób zarządzania i kierowania, stając się spółkami akcyjnymi. Formalnie w tych przedsiębiorstwach państwo zachowało własność i kontrolę nad nimi, ale miało ono mało bezpośred- 
niego wpływu na ich wewnętrzne zarządzanie. Oznaczało to wyraźnie, że tu elementy rynku kapitalistycznego i elementy kapitalistycznej własności zostały wbudowane w gospodarkę Chińskiej Republiki Ludowej tak, że nie było podstaw, aby nadal określać ją jako gospodarkę planową.

Przedstawiciele gospodarki rynkowej przyjęli te zmiany $\mathrm{z}$ zadowoleniem, widząc $\mathrm{w}$ nich uzupełnienie systemu ekonomicznego socjalistycznej gospodarki rynkowej. Ważnymi argumentami był wzrost PKB, a także duża dynamika rozwojowa chińskiej gospodarki, szczególnie w pierwszych trzydziestu latach. Podkreślano, że sektor kapitalistyczny w Chinach jest bardziej dynamiczny i bardziej efektywny, wydajny, określa się, że wzrasta on dwukrotnie szybciej niż sektor państwowy, co było ważnym argumentem, żeby w dalszym ciągu prywatyzować dalsze działy gospodarki narodowej. Faktycznie rzeczywistą wielkość sektora prywatnego w Chinach trudno jest określić, gdyż sektor ten często w oficjalnych danych jest zaniżany, np. zauważa się tendencję ignorowania małych przedsiębiorstw albo nawet niezaliczenia małych zakładów do sektora gospodarki prywatnej ${ }^{9}$.

Prywatne przedsiębiorstwa są często deklarowane jako społeczne lub kolektywne, co wpływa na pomniejszanie wielkości prywatnych przedsiębiorstw. W 2005 r. oceniano, że w Chinach sektor prywatny wytwarzał około 70\% PKB i charakteryzował się tendencją wzrostową. Aktualnie PKB liczone jest jako ogólna wartość cen wszystkich towarów i usług, które zostały w danym kraju i roku wytworzone. Jest to ważny wskaźnik wielkości gospodarki danego kraju. W 2018 r. PKB Chin oceniany był na 14,1 bln dol. USA, ale liczony w juanach powiększały go o 40-50\% - faktycznie

9 Ibidem, s. 50. 
więc ok. 20-21 bln dol. Jak już wspomniano, państwo zachowało własność w strategicznych gałęziach przemysłu, np. produkcja energii, ropa naftowa i petrochemia, telekomunikacja, górnictwo węglowe, komunikacja, szczególnie lotnicza, wodna i morska. Państwo sprawuje też pośrednią kontrolę w kierowaniu niepaństwową gospodarką, także przez system finansowy i podział środków finansowych. Z punktu widzenia interesów państwa, określa także relację juana do dolara i innych walut zagranicznych.

Planowanie centralne zostało zniesione, zastąpiono je wolnymi mechanizmami rynkowi i planowaniem indykatywnych, czyli wskaźnikowym obejmującym całe gałęzie gospodarcze, a bezpośrednio w odniesieniu do przemysłowych przedsiębiorstw państwowych, które zarządzane są jako spółki akcyjne na zasadzie komercyjnej. Tylko bardzo duże przedsiębiorstwa państwowe są zarządzane bezpośrednio przez zarządy (dyrektorzy, menadżerowie) podlegali bezpośrednio rządowi centralnemu. Przedsiębiorstwa te cechują się dużą autonomią, np. dzielą zyski, mają pewną ochronę ze strony państwa w razie niepowodzeń koniunktury.

Zdaniem J. Gepperta określenie „socjalistyczna gospodarka rynkowa" jest zdecydowanie fałszywe. Jej zamysł i koncepcja jest konsekwencją wejścia KPCh i ChRL na drogę prowadzącą do kapitalizmu i społeczeństwa burżuazyjno-kapitalistycznego. W związku z tym krytycy tej koncepcji określani są nie tyle w Chinach, lecz w Europie jako ortodoksyjni marksiści, twardogłowi, staliniści. Jednak obiektywna analiza przemian w Chinach potwierdza wniosek, że klasa robotnicza faktycznie odsunięta została od władzy, a nowy system wprowadza coraz większą nierówność między biednymi a bogatymi i w rzeczywistości prowadzi do powstawania coraz mocniejszej klasy kapitalistów. Jest to nowa forma rewizjoni- 
zmu, który doprowadził wcześniej do zniszczenia socjalizmu w ZSRR i państwach demokracji ludowej w Europie.

Chińscy politycy i teoretycy nazywają ten okres jako „początkowe stadium socjalizmu". Krytycy tej kategorii określają politykę Chin, np. Oskar Weggel jako „ideologię szarej strefy". Jego zdaniem Marks zarysował trzystopniową drogę rewolucyjnych zmian: kapitalizm-socjalizm-komunizm. KPCh wystąpiła z korektą tej koncepcji, lansując pięć stopni rozwoju: półfeudalizm/kapitalizm-nowa demokracja-socjalistyczna gospodarka towarowa - pełny socjalizm-komunizm. Obecna faza socjalizmu rynkowego wymaga stosowania wielkich środków, czerpiących z obu ustrojów w celu osiągnięcia maksymalnego wzrostu gospodarczego.

Zdaniem J. Gepperta ${ }^{10}$ model chińskich przemian doprowadzi do odrodzenia kapitalizmu w Chinach, który obecnie już prezentuje się jako kapitalizm państwowy. Kapitalistyczne stosunki produkcji prowadzą ostatecznie do burżuazyjno-kapitalistycznego państwa. Pojęcie „socjalistyczna gospodarka rynkowa" jest w najwyższym stopniu kategorią rewizjonistyczną i pozostaje w kontrze do marksistowskiej logiki, co potwierdzają wyniki badań licznych marksistów nie tylko niemieckich, ale także innych europejskich partii komunistycznych. W związku z tym należy poddać głębszej analizie kwestie nie tylko chińskiej bazy ekonomicznej, ale także nadbudowy, a w szczególności istoty państwa, partii komunistycznej, społeczeństwa i jego klas społecznych.

Wraz ze zwycięstwem rewolucji demokratycznej i socjalistycznej Chińska Republika Ludowa przyjęła kurs odbudowy kraju i przyspieszenia rozwoju przemysłu, co było możliwe dzięki znacjonalizowaniu wielkich i średnich zakładów prze-

10 Zob. ibidem, s. 52. 
mysłowych, bogactw naturalnych i scentralizowaniu zarządzania nie tylko przez administrację państwową, także przez wprowadzenie scentralizowanego planowania. Na wsi wprowadzono spółdzielnie produkcyjne (komuny ludowe) i usługowe, które harmonijnie wpisały się w praktykę od wieków stosowanego w Chinach gminnego władania ziemią przez wspólnoty wiejskie. Dzięki pomocy ZSRR i innych państw socjalistycznych powstały liczne nowe gałęzie przemysłowe, zakłady pracy, uruchomiono nowe działy produkcji i usług. Ocenia się, że pod koniec życia Mao Zedonga, na początku lat 70. XX w. chińska klasa robotnicza liczyła już ok. $100 \mathrm{mln}$ ludzi, co stanowiło jednak nadal niewielki udział w szybko rosnącej ludności chińskiej liczącej wtedy około $900 \mathrm{mln}$ obywateli, ale był to wyraźny postęp w budowaniu wyraźnej struktury gospodarczej i społeczno-klasowej Chińskiej Republiki Ludowej.

Wraz z wprowadzeniem programu i polityki Deng Xiaopinga i zmianą mechanizmu gospodarowania jako „socjalistycznej gospodarki rynkowej" nastąpiło przyspieszenie rozwoju gospodarczego i przemiany socjalno-klasowe nabrały większego tempa. Obecnie ocenia się, że chińska klasa robotnicza liczy ponad $320 \mathrm{mln}$ ludzi, a ponad prawie $280 \mathrm{mln}$ tzw. robotników sezonowych dojeżdża do pracy w wielkich miastach. W dalszym ciągu na wsi bytuje ponad $500 \mathrm{mln}$ ludzi, dla których rozdrobnione rolnictwo i towarzyszące im usługi są głównym źródłem utrzymania. Utrzymuje się głęboka różnica w dochodach między ludnością wiejską i miejską (1:3). Jak już wspomniano, urbanizacja kraju uczyniła w Chinach wielki krok naprzód. W 2020 r. w miastach zamieszkiwało ponad 60\% ludności, na wsi poniżej 40\%, przy czym poziom życia na wsi znacznie się podniósł ze względu na pracę potężnej armii chińskich „gastarbeiterów”, czyli mi- 
grujących do wielkich miast robotników sezonowych i przesyłających na wieś duże transfery pieniędzy. W następstwie zmienia się także na korzyść oblicze chińskiej wsi, buduje się liczne nowe domy, zakłady usługowe, powstaje nowa infrastruktura komunikacyjna, wyposażenie w nowoczesne urządzenia, prąd, telewizja, radio, telefony komórkowe, Internet, ochrona zdrowia, rozwój szkolnictwa. Chiny nie dopuściły do żywiołowego pędu mieszkańców wsi do miast, a także do powstawania nowych gospodarstw obszarniczych. Procesy przemian i transfery siły roboczej odbywają się pod kontrolą państwa i nie mają charakteru żywiołowego, tak jak to jest np. w niektórych państwach rozwijających się (Meksyk, Brazylia, Nigeria).

Oczywiście są koszty społeczne takiej polityki rozwoju, m.in. rosnące i pogłębiające się rozwarstwienie, nierówność rozwojowa regionów, rozbicie rodzin, skrywany wyzysk nadwyżek wiejskiej siły roboczej, dostrzegany głównie w prywatnych przedsiębiorstwach, gdzie słabo działają związki zawodowe i podstawowe organizacje partyjne KPCh. W licznych zakładach pracy nie są respektowane zasady BHP, zdarzają się katastrofy, mają miejsce liczne wypadki śmiertelne, występują także strajki. Można stwierdzić więc, że są to koszty dynamicznego rozwoju, niechciane przez władze i dążące do usunięcia ich przyczyn, ale $\mathrm{z}$ różnych powodów jest to bardzo trudne lub często jeszcze niemożliwe. Kierownictwo KPCh pod kierunkiem Xi Jinpinga opracowało 30-letni plan dalszego rozwoju (do 2050 r.), w rezultacie którego te dotychczasowe niedostatki mają być usunięte, a społeczeństwo ma osiągnąć poziom w pełni rozwiniętego społeczeństwa.

Według oficjalnych danych przedstawionych przez kierownictwo KPCh i rząd ChRL w latach 2019-2020 Chiny 
w ciągu kilkudziesięciu lat rozwoju wyprowadziły z nędzy 700 mln ludzi, w tym w ostatnim pięcioleciu (2016-2020) $99 \mathrm{mln}$ (z ekstremalnej nędzy, mierzonej dochodem 2 dol. dziennie). Dotyczyło to głównie najbiedniejszych regionów zachodnich, południowych i północnych Chin, obszarów historycznie opóźnionych w rozwoju, górzystych, jak Tybet, Xinjiang, Qinghai, pustynnych i stepowych, jak Mongolia, wymagających olbrzymich i nadzwyczajnych inwestycji gospodarczych w infrastrukturze komunikacyjnej, nękanych także przez klęski żywiołowe. Jest to wielki problem nie tylko ekonomiczny, socjalny, także demograficzny i etniczno-polityczny, gdyż regiony te są zamieszkane przez liczne mniejszości narodowe, np. Tybetańczyków, Ujgurów, Zhuang, Hui, Mongołów itd., gdzie odnotowuje się silne napięcia, częściowo podsycane z zewnątrz, np. w Tybecie i Xinjiangu.

Ocenia się, że w Chinach spośród tych 700 mln ludzi wyrwanych z głębokiej nędzy 400 mln osiągnęło już poziom średnich zarobków (niektóre źródła posługują się określeniem „klasa średnia”, wykorzystując klasyfikację amerykańskiej socjologii). Oznacza to, że około 660 mln Chińczyków nadal żyje w warunkach nie ekstremalnej, ale względnej biedy, jednak nie muszą oni umierać z głodu, dotyczy to głównie mieszkańców wiejskich obszarów. Niektóre źródła podają, że w dalszym ciągu w Chinach około 40 mln ludzi nadal żyje w warunkach ekstremalnej nędzy. Biorąc pod uwagę liczną kategorię ludzi nieznacznie przekraczających 2 dol. na dzień, można stwierdzić, że w Chinach jest nadal około $200 \mathrm{mln}$ ludzi żyjących na poziomie najbiedniejszych ludów Afryki. Poza tym słabością systemu socjalnego Chin jest nadal brak gwarantowanego przez państwo ubezpieczenia społecznego na wypadek bezrobocia, choroby, wypadku 
lub z powodu osiągnięcia wieku emerytalnego, co dotyczy głównie robotników sezonowych ${ }^{11}$.

W Chinach pogłębia się zróżnicowanie społeczne, odrodziła się burżuazja narodowa i olbrzymia część bogactwa narodowego znalazła się w rękach nowej burżuazji. Szczególną „karierę” robi w Chinach najbogatsza warstwa wielkiej burżuazji, czyli milionerzy, a szczególnie miliarderzy, którzy liczą swe bogactwa nie w juanach, lecz w dolarach. W środkach masowej informacji publikowane są często artykuły o życiu prywatnym, zasługach wielkich bogaczy i wychwala się ich jako ludzi wielce zasłużonych dla gospodarki Chin, są lansowani jako nowe pozytywne wzory zachowań osobowych. Liczą się z nimi także czynniki oficjalne, gdyż dysponują wielkim bogactwem, które przyczynia się do rozwoju gospodarczego Chin, ale potencjalne może być wykorzystane dla działań i celów politycznych. KPCh stara się utrzymać tę wpływową warstwę w swoistych ryzach nie zezwalając jej na samoorganizację polityczno-partyjną, ale mogą oni organizować się w różnych klubach i organizacjach środowiskowych, otworzono im możliwość o ubieganie się o członkostwo w Komunistycznej Partii Chin, a także mają wpływową reprezentację w Komisjach Konsultacyjnych, szczególnie w centralnej, w której uzgadniane są wspólne interesy i program rozwoju pod kierunkiem KPCh. Jest to pewna forma frontu narodowego, w której kształtuje się wola klasowo-narodowa zróżnicowanego społeczeństwa chińskiego, realizowana w kategoriach polityczno-państwowych.

Nie można także zapominać o potężnej korupcji, która jest od lat kulą u nogi chińskiego systemu prawnokarnego, a przede wszystkim politycznego i która niczym rak

11 Por. ibidem, s. 53. 
obejmuje nie tylko poszczególne części, ale cały organizm. O tym że problem ten wzrasta świadczą kolejne informacje o przypadkach korupcji w licznych strukturach aparatu państwowego i partyjnego, a nawet sięga do osób z najwyższych organów państwowych. Zdecydowaną walkę z korupcją zapowiedział na XIX Zjeździe KPCh w 2017 r. jej sekretarz generalny Xi Jinping. Miliarderzy są także przedmiotem swoistego podziwu niektórych mediów, które podkreślają, że chińska gospodarka jest już druga po ekonomii USA i w związku z tym musi ona mieć zbliżone czynniki potencjałów, jednym z nich jest liczba miliarderów i milionerów. Według danych publikowanych w amerykańskim magazynie „Forbes” USA przodują w licznych wskaźnikach gospodarczych, ale w liczbie miliarderów na pierwszym miejscu znajdują się Chiny. W 2020 r. liczyły one 799 miliarderów, USA natomiast miały „tylko” 626 miliarderów. Dalszy rozkład miliarderów w innych państwach przedstawia poniższa tabela:

Tabela. Ranking miliarderów na świecie

\begin{tabular}{|r|l|c|}
\hline 1. & Chiny & 799 \\
\hline 2. & USA & 626 \\
\hline 3. & Indie & 137 \\
\hline 4. & Niemcy & 122 \\
\hline 5. & Wielka Brytania & 119 \\
\hline 6. & Rosja & 91 \\
\hline 7. & Szwajcaria & 88 \\
\hline 8. & Brazylia & 69 \\
\hline 9. & Tajlandia & 57 \\
\hline 10. & Francja & 51 \\
\hline
\end{tabular}

Źródło: „China Internet Information”(CHC), Pekin. Podaję za: J. Geppert, op.cit., s. 53.

O tym jak wygląda kondycja ekonomiczna prywatnego sektora w Chinach świadczą następne dane. Zatrudnia 
on około $360 \mathrm{mln}$ ludzi (z około 780 mln ogółem zatrudnionych, w tym $180 \mathrm{mln}$ w chińskim rolnictwie). Oficjalne dane podają udział gospodarki prywatnej w wytwarzaniu rocznej wartości około 60\% (a niektóre dane mówią nawet o 70\%) PKB i oznacza to osiągnięcie wskaźników północnoamerykańskich i zachodnioeuropejskich przy konieczności uwzględnienia odmiennej struktury produkcyjnej. Ponadto w Chinach funkcjonuje już $68 \mathrm{mln}$ prywatnych małych zakładów i 27 mln większych przedsiębiorstw, które powodują wzrost udziału tego sektora w tworzeniu PKB. Przedsiębiorstwa te liczą nawet do 10 tys. zatrudnionych. W tej sytuacji nawet, gdy KPCh i kierownictwo państwowe przedstawiają system społeczny jako „socjalizm o chińskiej specyfice”, to w rzeczywistości jest to kapitalistyczna formacja społeczna. Członkowie nowej chińskiej burżuazji, w tym także członkowie KPCh budują fasadowy miraż i w rzeczywistości werbalne "socjalistyczne" roszczenie swej partii, jak i kierownictwa państwowego nie przeszkadza im, gdyż jest to, jak określa J. Geppert „ideologiczny szwindel”, a założeniem jego socjalnej i materialnej egzystencji nie jako socjalistyczna, a wręcz kapitalistyczna istota z jej chińską specyfiką ${ }^{12}$.

Przy analizie koncepcji socjalistycznej gospodarki rynkowej niezbędne jest określenie roli Komunistycznej Partii Chin, gdyż jest ona głównym instrumentem organizowania proletariatu do walki o wyzwolenie klasy robotniczej i ludu pracującego spod władzy kapitalizmu, obalenia go i budowy podstaw socjalizmu, a w perspektywie komunizmu. Komuniści i ich partia organizują i kształcą proletariat w klasę i dążą do rewolucji socjalistycznej w celu obalenia panowania burżuazji. Teoretyczne zasady komunistów są od-

12 Zob. ibidem, s. 54. 
zwierciedleniem powszechnie obowiązujących sprzeczności i stosunków społecznych, w tym walki klasowej obecnej między burżuazją a proletariatem. Jej celem jest zniesienie prywatnej własności środków produkcji i zniesienie wyzysku człowieka przez człowieka.

Komunistyczna Partia Chin w ciągu ostatnich czterdziestu lat bardzo się zmieniła, zachodzą w niej głębokie przewartościowania, znacznie zmieniła się baza członkowska w partii i jej struktura członkowska. KPCh jest kierowniczą siłą Chin, prawnie opiera się na Konstytucji Chińskiej Republiki Ludowej. Podstawową zasadą organizacyjną jest zasada centralizmu demokratycznego. W Chinach poza KPCh jest także osiem innych, tzw. demokratycznych, środowiskowych partii, które budują swe programy i działania w oparciu o system koalicji stałej typu socjalistycznego i uznają kierowniczą rolę KPCh.

Przemiany zapoczątkowane w 1978 r. przyczyniły się do wyraźnego osłabienia udziału robotników w strukturze członkowskiej partii bardzo silny jest udział przedstawicieli warstwy chłopskiej, różnych grup inteligenckich, a od 2002 r. kierownictwo partii pod kierunkiem ówczesnego sekretarza generalnego KC KPCh Jiang Zemina umożliwiło wstępowanie do partii przedstawicielom biznesu (jeśli uznawali program i politykę partii). W następstwie partia zaczęła się przekształcać w partię liberalizmu gospodarczego. W partii, która dotychczas dopuszczała możliwość rywalizacji różnych grup i szkół ideologicznych o podłożu marksistowsko-socjalistycznych od co najmniej 2006 r. zaczęły walczyć o wpływy zrzeszenia przedsiębiorców, związków zawodowych, organizacji chłopskich, korporacji regionalnych lub intelektualistów partyjnych. Powstały trzy wiodące nurty: 
1. nowa lewica, która krytykowała społeczne następstwa polityki liberalizacji i domagająca się większego wpływu państwa na kierowanie gospodarką;

2. neoliberałowie - wypowiadali się przeciwko zbyt dużej ingerencji państwa i żądali dalszego ograniczenia ingerencji państwa w gospodarce;

3. demokratyczni liberałowie - opowiadali się za dalszymi burżuazyjnymi reformami politycznymi ${ }^{13}$.

Mimo tych trendów Komunistyczna Partia Chin odgrywa nadal rozstrzygającą rolę i nie zamierza się oficjalnie dzielić i poddawać. Trzeba podkreślić, że zmiany modelu gospodarczego i ich realizacja w ubiegłych ponad czterdziestu latach wyszły z partii i w dalszym ciągu partia jest głównym centrum reformy i jedynym autorytetem tak wewnątrz kraju, jak i w stosunkach zagranicznych. Można nawet stwierdzić, że mimo iż podejmowane są ze strony nielicznych dysydentów krytyka polityki KPCh i stworzenie jakiejś alternatywnej koncepcji, to nie przynoszą znaczących rezultatów.

W następstwie reform, gospodarczego otwarcia się Chin i postępu we wzroście gospodarczym poprawiła się sytuacja ekonomiczna kraju i rozwiązano liczne problemy, także socjalne ludności. Dotyczy to głównie jednak nowej burżuazji i tzw. „klasy średniej”, ale jest w dalszym ciągu wielka rzesza już nie ekstremalnej nędzę, ale biedy i ubogości, a także bezrobocie, które ma co prawda charakter frykcyjny i nosi łagodną tendencję wzrostową, obecnie około 5\%. Rozwierają się nożyce między wąską grupą bogatych i super bogatych a przeciętnością i biedą. W oficjalnych wystąpieniach podnosi się znaczenie społeczne „średniej klasy”, definiując ją jako ludzi osiągających średnie dochody (400 mln).

13 Por. ibidem, s. 55. 
Podnosi się wolność gospodarowania, pracy, inicjatywność, rywalizację i wolność podróżowania jako cechy „otwartego społeczeństwa". Obywatele ChRL masowo wyjeżdżają już nie tylko do Hongkongu czy na Tajwan, ale także do Singapuru. Chińczycy rywalizują z Japończykami w wycieczkach do USA, Kanady, Australii i krajów europejskich. Może to wywierać wpływ na przejmowanie wartości i sposobów zachowania z państw kapitalistycznych. Powstaje jednak pytanie czy można tego uniknąć w epoce globalizacji. Ponadto Chińczycy są inteligentni i nie tylko zachłystują się blichtrem Zachodu. Dostrzegają jego słabości i niedostatki klasowe, np. głęboką nierówność społeczną, wielkie bezrobocie, manifestacje niezadowolonych grup, cywilizacyjne i klasowe różnice między państwami rozwijającymi się a rozwiniętymi.

Komunistyczna Partia Chin jest nie tylko największą partią komunistyczną, jest to największa organizacja społeczno-polityczna w skali całego świata. Ostatnie dane z 2020 r. podają liczbę ponad 90 mln członków, jest to więc ok. 9\% dorosłej populacji, co dokumentuje masowość partii. Obserwacja życia partyjnego w Chinach dowodzi, że niełatwo stać się członkiem partii, obowiązują bowiem liczne kryteria i wymagania ideowo-polityczne, polityczne, środowiskowe, trzeba uzyskać rekomendacje innych członków, a także cieszyć się dobrą opinią własnego środowiska. W omawianym okresie znacznie wzrosła liczebność KPCh, np. między 2005 a 2016 r. liczba członków wzrosła o 26\%. Jednocześnie znacząco zmieniła się struktura członkowska. Pogłębiająca się pluralizacja ludności wpływa odpowiednio na zróżnicowanie w strukturze społecznej partii. Rosnące rozwarstwienie społeczeństwa, lansowanie i przejmowanie nowych wzorów konsumpcji, zmiany w rankingu wartości, szczególnie wśród 
młodego pokolenia rodzi nowe potrzeby i pokusy dostosowania się i naśladowania do wzorów zachowania często niemających żadnego związku z chińskimi zwyczajami. U pewnej części nie tylko młodzieży występują chęci naśladowania i powielania american of life. Następuje wyraźna pluralizacja społeczeństwa, szczególnie wyraźnie widoczna $\mathrm{w}$ wielkich metropoliach, jeszcze jaskrawiej prezentuje się to w Hongkongu, Makao, nie mówiąc o Tajwanie. Zmiany te wpływają na aspiracje szczególnie młodego pokolenia i bez wątpienia jest to poważny problem ideowy i cywilizacyjny dla kierownictwa KPCh.

Jednocześnie w Chinach w ostatnich latach nastąpiła aktywizacja pozostałych partii tzw. demokratycznych lub środowiskowych, działających głównie w środowiskach inteligenckich, które odnotowują wzrost aktywności i wzrost liczby członków, a także ożywia się ich struktura organizacyjna na szczeblach prowincjonalnych, miejskich i lokalnych ${ }^{14}$. Liczba członków KPCh w latach 1985-2016, a więc w ponad 30 latach zwiększyła się prawie dwukrotnie, osiągając prawie $90 \mathrm{mln}$. W 2005 r. 5,4\% społeczeństwa legitymowało się członkostwem partii, ale tylko w ciągu następnych jedenastu lat (2005-2016) liczba członków partii wzrosła o więcej niż 1/4 (26\%), ubiegało się o członkostwo $20 \mathrm{mln}$ chętnych, ale tylko co jedenasty był przyjęty, a więc w sumie mniej niż $2 \mathrm{mln}$.

W strukturze nowych członków partii zauważalny był wzrost młodzieży studenckiej i legitymujących się wyższym wykształceniem. Następuje także wyraźne zmniejszenie tradycyjnej klienteli partii. Tradycyjnie ruch robotniczy rozwijał swą działalność w szeregach fabrycznego proletaria-

14 Ibidem, s. 56. 
tu, ale jak wiadomo odrodzona przez Mao Zedonga KPCh znalazła swą bazę wśród proletariatu wiejskiego i biednego chłopstwa i dopiero po zdobyciu władzy w 1949 r. wraz z przyspieszoną industrializacją zaczęła nadrabiać historyczne opóźnienia i rozszerzać swą działalność o szeregi robotników przemysłowych. Znalazło to także wyrażenie w zasadzie nierówności głosów w wyborach, głosy miejskich (proletariackich) wyborców były dwa razy silniejsze niż wyborców wiejskich, co znalazło odzwierciedlenie także w strukturze klasowej organów przedstawicielskich. Mimo to nadal przewagę ilościową w przyjęciach mieli kandydaci ze wsi. W 2005 r. robotnicy i chłopi w KPCh stanowili $43,2 \%$, ale od tego czasu systematycznie zmniejszał się udział obu tych kategorii w partii, w 2016 r. spadł on do 37,0\%. Jednocześnie wzrastał udział środowisk akademickich (z dyplomami szkół wyższych) odpowiednio z 16,9\% na $45,9 \%$, a więc znacznie ponad $100 \%$. W 2012 r. udział absolwentów z wyższym wykształceniem osiągnął już 40,0\% i przewyższał udział robotników i chłopów (38,3\%). Warto też odnotować, że w konsekwencji szybkich zmian gospodarczych szybko spada liczba ludzi zatrudnionych w rolnictwie, co znajduje też wyrażenie we wzroście współczynnika urbanizacji (w 2020 r. ponad 60\%), co roku liczba mieszkańców miast zwiększa się od 0,8 do $1 \%$.

Wzrost udziału w strukturze partii absolwentów szkół wyższych, nie tylko "normalne” 5-letnie studia (magisterskie), także 3-letnie (zawodowe) oraz w największym zakresie absolwentów różnych z reguły 2-letnich koledżów [w Polsce zaliczanych jako szkoły (technika) pomaturalne] jest konsekwencją przyjęcia modelu i struktury szkół wyższych z USA. Tak duży udział w strukturze partii ludzi z wyższym wykształceniem jest dostrzeżeniem przez kierownictwo 
KPCh roli i znaczenia wykształcenia, które coraz bardziej ma zastosowanie i staje się niezbędne w epoce wiedzy. Wzrasta rola i znaczenie wykształcenia na poziomie uniwersyteckim w produkcji, technologii, komunikacji, zarządzaniu. Oznacza to, że w Chinach praktycznie wszyscy absolwenci szkół wyższych są członkami Komunistycznej Partii Chin.

Na uwagę zasługuje zmiana struktury wiekowej KPCh. W latach 2005-2016 udział grupy poniżej 25. roku życia lekko się podniósł z 23,0 do 25,4\%. Jednocześnie mniej więcej w tej samej relacji wzrósł udział grupy powyżej 60. roku życia odpowiednio z 23,0 do 26,9\%, co także jest następstwem wzrostu długości życia Chińczyków. Decydującą rolę odgrywa grupa środkowa między 35. a 60. rokiem, która była i jest jądrem partii. Jednak ostatnio cechuje ją pewien spadek, w 2005 r. - 54,0\%, w 2016 - 47,7\%, a więc o ok. 6,3\%, a w liczbach bezwzględnych odpowiednio 42,6 i 47,7\% $(4,4 \mathrm{mln})$. Generalnie Komunistyczna Partia Chin powoli starzeje się, ale nie jest to jeszcze trend alarmowy.

Innym zjawiskiem socjologiczno-politycznym jest napływ do KPCh reprezentantów nowych warstwa społecznych, a nawet burżuazji. Zaliczyć do nich można prywatnych biznesmenów, samodzielnych, w naukowej obsłudze sektora usługowego, także profesjonalnych specjalistów w sprawach urzędowych. Udział tych grup wśród młodych członków partii jest niewielki i cechuje się niską tendencją wzrostową. W 2005 r. wynosił on tylko 11 tys. (z 2,4 mln nowych członków KPP).

W związku z tym celowe jest odniesienie się do występującej w tym okresie w oficjalnych statystykach kategorii „inni”, „pozostali” (6\%), w kategoriach liczbowych ok. 5,4 mln, którą zapewne budowali przedstawiciele nowego biznesu (burżuazji), którym kierownictwo od 2002 r. zezwo- 
liło na wstępowanie w szeregi KPCh. Była to grupa niewiele mniejsza niż robotnicy (8\%), ale zapewne ze względu na swe bogactwo miała znacznie większe możliwości wpływu nie tylko na życie ekonomiczne. Aktualnie ta relacja zmieniła się mocniej na niekorzyść robotników.

Udział kobiet od lat utrzymuje się na poziomie ok. 20\% i jest niezadowalający, kierownictwo partyjne dąży do poprawy statystyk, ale postęp jest niewielki. Zapewne rozmija się tu praktyka oraz teoria i przykłady idą z góry. Jeszcze niższy jest udział kobiet w składzie Komitetu Centralnego, a wręcz alarmujący w składzie Biura Politycznego. W poprzedniej kadencji była tylko jedna towarzyszka, a w Stałym Komitecie BP KC KPCh (siedem osób) nie było ani jednej kobiety, a jest to najwyższe i operacyjne gremium władzy nie tylko partyjnej. Można domniemywać, że przyczyną są nieprzezwyciężone ciągle konserwatywne tradycje kulturowe, czerpiące z konfucjanizmu, życie publiczne było i jest domeną mężczyzn, miejsce kobiet określone było obowiązkami rodzinnymi i domowymi. Obecnie zmienia się to na niższych szczeblach życia publiczno-produkcyjnego i organizacji społeczeństwa, ale do realizacji pełnej zasady równości kobiet i mężczyzn jest jeszcze daleko. Nowe kierownictwo KPCh na czele z Xi Jinpingiem dąży usilnie do poprawy sytuacji i w latach 2005-2016 udział ten zwiększył się z 19,2 do $25,7 \%$, a więc wzrost o $6,5 \%$.

W konsekwencji zmian struktury produkcyjno-zawodowej, demograficznej i społeczno-klasowej w Chinach, także w KPCh, nastąpiły zmiany, które osłabiają dotychczasową zwartość i jedność ideowo-polityczną chińskiej partii komunistycznej. Rośnie także znaczenie nieformalnych grup, które w wewnętrznych dyskusjach podkreślają, rozwijają i pogłębiają potrzebę różnorodności, a nawet niejednoli- 
tości bazy partyjnej jako pozytywnego pluralizmu partii. W gruncie rzeczy jest to nieoficjalny i niezwerbalizowany nurt socjaldemokratyczny, który wystąpił w partiach postkomunistycznych w b. ZSRR i dawnych państwach demokracji ludowej. Jest także grupa, która chciałaby ograniczyć rolę ideologii marksistowsko-leninowskiej (w wydaniu maoistowskim), widząc w niej zagrożenie dla dalszych „demokratycznych" reform. Jednak nadal inicjatywa i kierownictwo w partii należy do większości marksistowskiej, która reformy traktuje jako taktykę, a strategicznym celem jest budowa socjalizmu o chińskiej specyfice i w perspektywie komunizmu, co z trybuny XIX Zjazdu KPCh w 2017 r. wyraźnie zadeklarował jej sekretarz generalny Xi Jinping.

Na uwagę zasługuje kwestia znaczącego, a nawet dużego napływu w ostatnim okresie młodych absolwentów szkół wyższych. Ten trend (o czym już wspomniano) był zauważalny od 1981 r. Reformy wdrażane przez Deng Xiaopinga wymagały nowego myślenia i nowych kadr, profesjonalnie wykształconych, znających języki obce, otwartych na świat, ale jednocześnie zaangażowanych po stronie socjalizmu i wartości czerpiących z aksjologii z marksistowskiej. KPCh nie odżegnała się od wielkiego dorobku teoretycznego i zasług politycznych Mao Zedonga (krytykując jego błędy i wady) i do dziś Przewodniczący Mao cieszy się ogromnym szacunkiem, a nawet kultem nie tylko wśród członków partii. Ale nie oznaczało to, że wszyscy tacy byli, o czym świadczyły wydarzenia w 1989 r., kiedy przez kilka miesięcy w gremiach $\mathrm{KPCh}$, nawet w KC i Biurze Politycznym trwały ostre dyskusje, w jakim kierunku mają pójść Chiny, czy tak jak w b. ZSRR i KDL-ach ku kontrrewolucji i kapitalizmowi, czy utrzymania socjalizmu, jego zdobyczy społecznych i przyspieszenia rozwoju gospodarki Chin w celu dalszego 
rozwoju i umocnienia socjalizmu. Jak wiadomo te głębokie różnice ideowo-polityczne zakończyły się wielkimi demonstracjami części antysocjalistycznie nastrojonej młodzieży studenckiej na placu Tiananmen w Pekinie, rozpędzonej zbrojnie przez oddziały Chińskiej Armii Ludowo-Wyzwoleńczej na wniosek Deng Xiaopinga i większości Biura Politycznego KC KPCh. Był to wyraźny, nawet bolesny sygnał ze strony KPCh, szczególnie ojca reform i otwarcia Deng Xiaopinga, że w Chińskiej Republice Ludowej kontrrewolucja nie przejdzie i które określiły dalsze kierunki przemian w Chinach w ostatnich ponad czterdziestu latach.

Zarysowane wydarzenia miały konsekwencje w zmianach w strukturach partyjnych. Starsze i z reguły słabiej wykształcone kadry partyjne, często weterani rewolucji i Długiego Marszu musieli odejść, lecz zapewniono im miejsce w honorowej „Radzie Starszych”, niemającej realnego wpływu politycznego, lecz dokumentującej ciągłość ideowo-polityczną starego i nowego kursu partii. Sam Deng Xiaoping (także należący do tej wiekowej generacji) nie przyjął żadnej ważnej funkcji, choć do końca życia w 1996 r. cieszył się wielkim autorytetem ideowo-politycznym i miał decydujący wpływ na politykę partii i państwa.

Podjęcie tak wielkiego dzieła jak chińskie reformy ustrojowe w gospodarce i szerokie otwarcie na zewnątrz wymagało wielkiej odwagi ideowo-politycznej, perspektywicznego myślenia, prawidłowego zdiagnozowania przez KPCh sprzeczności wewnętrznych i międzynarodowych. KPCh musiała poszukiwać własnej drogi do socjalizmu w nowych warunkach wewnętrznych i międzynarodowych. Na niewiele przydały się doświadczenia z wczesnych etapów rozwojowych innych państw socjalistycznych. Jednocześnie narastały zagrożenia ze strony imperializmu i kapitalizmu, 
z którym Chińczycy chcieli pokojowo kooperować na zasadach wzajemnych korzyści, a nawet nie obawiali się wpuścić do siebie olbrzymiego kapitału inwestycyjnego, technologicznego, wielkich korporacji, banków, a także rozwijali szeroką wymianę kulturalną i naukową. Jak wiadomo po więcej niż po czterdziestu latach przyniosło to epokowe zmiany i wyniki głównie w ekonomice. Ale rosnący w Chinach kapitalizm mimo zapór i przeciwdziałań ze strony KPCh ludowego państwa oddziałuje i odradza kapitalistyczne stosunki i wpływa na kształtowanie się wśród części społeczeństwa kapitalistycznych wartości i prób naśladowania burżuazyjnych wzorów sposobu życia głównie w formie american way of life. Walka klasowa między kapitalizmem a socjalizmem, a w kategoriach klasowych między burżuazją a proletariatem, odbywa się nie tylko na arenie międzynarodowej, ma ona miejsce także między odrodzonym i coraz silniejszym chińskim kapitalizmem, wspomaganym przez działające w Chinach wielkie korporacje kapitalistyczne, a także wielkie ośrodki burżuazyjne na świecie, głównie państwa imperialistyczne a socjalistyczną gospodarką w Chinach, chińską klasą robotniczą i innymi ludźmi pracy, partią komunistyczną i ChRL jako socjalistycznym państwem. Powstała niespotykana w dziejach realnego socjalizmy wielka dychotomia między w większości kapitalistyczną bazą a socjalistyczną nadbudową, gospodarka i społeczeństwo niezwykle hybrydowe i sprzecznościowe, którego dialektykę da się zdiagnozować i zrozumieć jako długotrwały okres przejściowy od kapitalizmu do socjalizmu, choć krytycy tego historyczno-ustrojowego eksperymentu określają go wręcz odwrotnie jako okres przemian od socjalizmu do kapitalizmu.

W rzeczywistości w Chinach toczy się ostra walka klasowa na wszystkich szczeblach organizacji społeczeństwa, 
w samej partii, w aparacie państwowym, w organizacjach społecznych, na uczelniach, w kulturze. Za socjalizmem przemawiają liczne racje społeczne i ekonomiczne, ale jednocześnie chińska gospodarka musi nadrobić liczne opóźnienia technologiczne i strukturalne gospodarki i społeczne, co wymaga czasu, spokoju wewnętrznego i pokoju na arenie międzynarodowej. Zdecydowana większość społeczeństwa popiera politykę i reformy gospodarcze KPCh ze względu na duży wzrost gospodarczy, ale także poprawy własnej sytuacji ekonomiczno-socjalnej ludzi pracy. Polityka KPCh cieszy się także poparciem z powodu wzrostu znaczenia ChRL na arenie międzynarodowej i umacnia nowy patriotyzm Państwa Środka. Chińczycy udzielają poparcia KPCh także z powodu tradycji konfucjańskich, obdarzając wielkim autorytetem kiedyś cesarza (obecnie KPCh), który ma „Mandat Nieba”, ale nie tylko z tego powodu, główny jest czynnik ekonomiczno-socjalny oraz pokój i pomyślność na arenie międzynarodowej. M.in. i nie tylko z tego powodu chętnie przyjęli i akceptują jako ważną normę życia społecznego zasadę harmonii społecznej, która ułatwia w zasadzie bezkonfliktowe kierowanie wielkimi przemianami i procesami społecznymi przez KPCh.

Na odrębną uwagę zasługuje rosnąca pozycja i rola wielkiej i średniej burżuazji narodowej i drobnomieszczaństwa. Można mieć wątpliwości czy wszyscy z tej klasy popierają socjalizm i ideały społeczeństwa egalitarnego. Bogactwo i jego demonstracja publiczna stały się obecnie pożądanymi wartościami społecznymi i wpływają na zmiany w hierarchii wartości szczególnie młodego pokolenia. Z badań socjologicznych przeprowadzonych wśród studentek przed kilku laty wynika, ze miłość jako warunek zawarcia związku małżeńskiego była dopiero na dalszym miejscu. Na pierw- 
szych sytuowała się pozycja materialna partnera, dobra praca i mieszkanie, wśród dolnych warstw lansowany jest drobnomieszczański sposób życia, zarobkowania, dążenie do własnego warsztatu pracy. Dodatkowymi czynnikami jest spekulacja, wielka korupcja i pogłębiające się różnice między nie tylko drobnym i średnim biznesem, ale prężnymi, mobilnymi i wielkimi prywatnymi korporacjami, w których z reguły na tych samych lub podobnych stanowiskach zarabia się więcej (często za dodatkowe godziny pracy) niż w firmach państwowych, społecznych. O tym, że narastają te problemy świadczą informacje o masowych strajkach, rozruchach na tle etnicznym (np. w Xinjiangu), a także wręcz ruchy dysydenckie typu Liu Xiaobo, dążące do zmiany obecnego kapitalizmu państwowego w „normalny” kapitalizm, a więc wprowadzenia ustroju nie tylko liberalno-gospodarczego, także pluralistycznego w sensie ustroju burżuazyjnego wraz z daleko idącą autonomią zarządzania, autonomią nie tylko regionów z dużym udziałem mniejszości etnicznych, ale także dla typowych chińskich prowincji. Wprowadzenie tych „reform” oznaczałoby w praktyce osłabienie rządu centralnego, wzrost tendencji decentralizacyjnych i w gruncie rzeczy prowadziłoby do rozczłonkowania Chin, upadku socjalizmu i podporządkowanie Chin państwom imperialistycznym, do czego KPCh i wszyscy chińscy patrioci nie mogą dopuścić, mając na uwadze skutki rozpadu ZSRR i KDL-ów w Europie.

Dopływ do partii dużej grupy młodzieży akademickiej, która pobiera naukę i wiedzę nie tylko w chińskich uniwersytetach i innych szkołach wyższych, także liczną ponad półmilionową grupę studentów i doktorantów, którzy studiują bądź ukończyli studia w uczelniach USA, państwach europejskich, w Japonii, Singapurze, Australii itd. rodzi 
nowe problemy ideowo-polityczne. Kiedyś większość tej młodzieży kuszona perspektywą wysokich zarobków pozostawała w tych krajach i podejmowała pracę zawodową, decydując się na emigrację. Obecnie ze względu na porównywalne zarobki w firmach chińskich i zagranicznych w Chinach, chętnie powracają, podejmują pracę, awansują. Z reguły ci młodzi ludzie cechują się wysokim patriotyzmem i szacunkiem do chińskiej kultury, jej historii i obyczajowości. Często integrują się z miejscowymi Chińczykami, tworzącymi dobrze zorganizowane i funkcjonujące „Chinatown”. Zdarzają się przypadki asymilacji Chińczyków i małżeństwa mieszane, ale nie są one masowe.

W związku z tym KPCh prowadzi w partii intensywne szkolenia, konferencje i treningi ideowo-polityczne. $\mathrm{Na}$ chińskich uczelniach stale obecne są gazety wielkich hieroglifów z informacjami, także banery z aktualnymi hasłami ideowymi i politycznymi. W programach studiów prowadzone są wykłady, seminaria i ćwiczenia z tzw. przedmiotów ideologicznych, w tym marksizm, maoizm, teoria Denga, filozofia, nauki polityczne, naukowy socjalizm, elementy ekonomii politycznej, także szkolenie wojskowe studentów i studentek z dużym udziałem treści ideowo-politycznych i patriotycznych. Pracę ideowo-polityczną w podstawowych organizacjach partyjnych prowadzi się non stop i wcale nie jest ona formalnie traktowana.

Trudno jest dokładnie określić jak definiują chińscy marksiści obecne sprzeczności wewnętrzne i międzynarodowe. Przyjęty kurs gospodarki rynkowej i szerokiego otwarcia na zagranicę, dążenie do jak najszerszego styku z najbardziej rozwiniętymi państwami kapitalistycznymi w celu pozyskania przodujących technologii przemysłowych, ale także elektroniki, technotroniki, Internetu G5, sztucznej inteligencji 
itd. wymagało od Chin maksymalnego wyciszenia hasła walki klasowej nie tylko w sferze międzynarodowej, także wewnątrz kraju. Jednocześnie sięgnięto do starych wartości i zasad konfucjanizmu, np. harmonii społecznej, co przyniosło wymierne rezultaty ekonomiczne i społeczne, ale jednocześnie odrodziło częściowo stare sprzeczności społeczne i powstały nowe, odpowiednio do zmian epoki. W każdym razie historyczny przełom zapoczątkowany przez reformy Denga przyniósł Chinom wielkie rezultaty gospodarczo-społeczne, a kategoriach międzynarodowych wyrosły one na czołowe mocarstwo nieuznające hegemonii USA i konsekwentnie realizujące rozwój według oryginalnej chińskiej drogi, co nie może się podobać USA i innym państwom kapitalistycznym.

Światowe ośrodki burżuazyjne i państwa imperialistyczne od dawna dążą do rozprawienia się z Komunistyczną Partią Chin i Chińską Republiką Ludową. Jeszce przed zwycięstwem rewolucji ludowej w 1949 r. opierały się one na chińskiej burżuazji i Kuomintangu. W latach 30. XX w. do walki o Chiny przystąpiła Japonia, odrywając Mandżurię i okupując olbrzymie obszary Chin nadmorskich i centralnych. KPCh prowadziła zdecydowaną walkę z agresorem japońskim, co przyniosło jej duże uznanie i autorytet wśród chińskiego ludu. W 1949 r. powstała Chińska Republika Ludowa, co ograniczyło wpływy USA praktycznie do Tajwanu i jednocześnie zamroziło stosunki USA z Chinami ludowymi do połowy lat 70. USA i mocarstwa zachodnie z dużą radością przyjęły deklarację Deng Xiaopinga o reformach gospodarczych i szerokim otwarciu się na kapitalizm i współpracę z nim, mając na uwadze wielkie możliwości robienia "kokosowych interesów” w Chinach. Były one przekonane, że z komunistycznymi Chinami będzie im znacznie 
łatwiej niż ze Związkiem Radzieckim i innymi państwami socjalistycznymi w Europie. Jak dowodzą wydarzenia ostatnich ponad czterdziestu lat burżuazyjne ośrodki bardzo się w tych rachubach przeliczyły. Owszem, osiągane zyski ciągnięte z Chin, ich olbrzymiego rynku, wielkich bogactw naturalnych i taniej siły roboczej, a także zainwestowanych w Chinach wielkich kapitałów były olbrzymie i wielokroć opłacały się, ale jednocześnie Chińczycy produkowanymi przez siebie tanimi towarami zalali prawie cały świat i stawali się coraz bardziej konkurencyjni na światowych rynkach. Obecnie sprzeczności te przybierają charakter nowej wojny handlowej, podejmowane są antychińskie restrykcje, sankcje, embargo, co w międzynarodowych stosunkach gospodarczo-handlowych przybiera formę protekcjonizmu, którą jako doktrynę wobec ChRL ogłosił były prezydent USA D. Trump. W chińskiej polityce USA pojawiły się nawet groźby użycia środków wojskowych, co przybrało charakter otwartych gróźb wobec najbliższego zaprzyjaźnionego państwa z ChRL Koreańskiej Republiki LudowoDemokratycznej. Nawiasem mówiąc tę politykę w stosunku do ChRL zapowiedział kontynuować nowy prezydent J. Biden, który skierował w stronę Morza Południowochińskiego lotniskowiec „Theodor Roosevelt” z flotyllą okrętów towarzyszących. Jednocześnie Amerykanie uaktywnili politykę antychińską wśród sojuszników azjatyckich i australijskich, a także z NATO, w tym Anglii, Francji, Niemiec, a także Polski. Chińska Republika Ludowa jest traktowana przez imperializm USA jako główne zagrożenie.

Z dotychczasowej analizy wynika, że generalnie ta długotrwała konfrontacja między ChRL a głownie USA przebiega korzystnie dla Chin, choć nie można jeszcze ogłosić ich zwycięstwa i obecnie sprawa nie tylko Chin, także socja- 
lizmu ponownie nabiera nowego znaczenia. Chińska droga do socjalizmu jest $\mathrm{z}$ uwagą studiowana teoretycznie głównie w państwach rozwijających się, a nawet podejmowane są próby zastosowania chińskiego modelu rewolucji socjalistycznej np. w Nepalu, wcześniej na Kubie, w Wenezueli, a także zastosowania socjalistycznej gospodarki rynkowej jako sposób na szybszy rozwój takich państw socjalistycznych, jak Wietnam i Kuba. Czyni się nawet pewne nieśmiałe kroki w tym kierunku w KRLD, a także w Laosie i Kampuczy, które deklarują antykapitalistyczną drogę rozwoju i demokracji ludowej.

Jednocześnie polityka ta rodzi określone niepożądane, a nawet być może niechciane następstwa, jak również sprzeczności, które mogą mieć negatywny wpływ na dalszy rozwój, jak i losy Chińskiej Republiki Ludowej. Jak wspomniano, w KPCh następuje systematyczny spadek liczby robotników i chłopów. W 2017 r. robotnicy stanowili 6,7 mln (6,1\%), a w 2019 r. 6,4 mln (6,0\%) ogółu. Jakie są przyczyny tego spadającego trendu. Po pierwsze, podczas prywatyzacji przedsiębiorstw państwowych miliony ludzi utraciło swe miejsca pracy. Ogólna liczba bezrobotnych wynosiła wtedy $4 \%$, obecnie zwiększyła się do $5 \%, 1 \%$ to jest ok. $6 \mathrm{mln}$, przy czym bezrobocie w Chinach obejmuje tylko bezrobotnych w miastach. Zatrudnieni w swych małych biedniackich gospodarstwach rolnych mają minimum niezbędne do życia. Dotyczy to także tzw. robotników sezonowych, którzy nie mają możliwości nabycia tzw. „hukou” (prawa zameldowania) i nie są wliczani do miejskich statystyk. Po drugie, wraz z prywatyzacją, a także likwidacją niektórych przedsiębiorstw następowało często zerwanie więzi i łączności z podstawową organizacją partyjną. Powstające od nowa prywatne przedsiębiorstwa chętniej zatrudniały chłopów i robotników 
sezonowych, którzy oderwani od swego naturalnego środowiska, rodziny, będący stale w podróży nie bardzo mieli czas i możliwość angażować się w działalności partyjnej, a nawet, jeśli mieli, więź z uległa osłabieniu lub zerwaniu.

Przypomnijmy, że Statut KPCh, podobnie jak Konstytucja ChRL jednoznacznie określają, że Partia jest awangardą klasy robotniczej, a „Chińska Republika Ludowa jest państwem socjalistycznym jako demokratyczna dyktatura ludu, kierowana przez klasę robotniczą i opierająca się na sojuszu robotników i chłopów. System socjalistyczny jest podstawą systemu Chińskiej Republiki Ludowej" (art. 1 Konstytucji ChRL z 1982 r.). Nowa polityka ekonomiczna przyniosła olbrzymi rozwój kraju, powstało tysiące nowych zakładów pracy, całych gałęzi gospodarczych, szczególnie przemysłowych, w tym także w prowincjach słabo rozwiniętych, zatrudniające wysoko kwalifikowanych robotników. Stopniowo zmienia się charakter zawodowy chińskiej klasy robotniczej, podniosła się rola wykształcenia zawodowego i ogólnego. Oczywiście procesy te mają charakter globalny i znalazły wyrażenie w amerykańskiej socjologii pracy jako blue collars $i$ white collars jako różnice między tradycyjną klasą robotniczą z dominującą pracą fizyczno-manualną i nowoczesną klasą robotniczą, obsługującą skomplikowane maszyny i urządzenia, w której czynnościach występuje przewaga czynności umysłowo-technicznych.

Te procesy występują w całej okazałości w Chinach, przy czym w niektórych gałęziach przemysłowych przybierają one bardziej drastyczny wyraz ze względu na nierównomierność rozwoju oraz modernizacji poszczególnych gałęzi przemysłu i prowincji. Wyrosły wielkie i najnowocześniejsze kombinaty, zatrudniające często dziesiątki tysięcy pracowników, produkujące skomplikowane wyroby i urzą- 
dzenia o najwyższych parametrach technicznych, niewiele różniące się od korporacji amerykańskich czy zachodnioeuropejskich, a jednocześnie w dalszym ciągu są eksploatowane np. stare kopalnie z przestarzałymi elementami infrastruktury, w których częsta jest wypadkowość. Dotyczy to także przemysłu chemicznego, budownictwa, szczególnie w nadal zacofanych regionach południowych, zachodnich i północnych. Stosunkowo niski poziom kwalifikacji zawodowych i poczucia przynależności do klasy robotniczej jest udziałem robotników sezonowych, zadowalających się najniższymi stawkami i przyjmujących najgorsze warunki pracy, Można ich porównać do częstych w Polsce Ludowej tzw. chłopo-robotników. Jak już wspomniano, główną dźwignią rozwoju były potężne inwestycje w miastach i prowincjach nadmorskich, w późniejszym czasie w prowincjach środkowych Chin, gdzie nowoczesna produkcja wymagała kadr robotniczych o wysokich i najwyższych kwalifikacjach zawodowych. Ocenia się, że w ciągu ponad czterdziestu lat rozwoju gospodarki klasa robotnicza potroiła swe szeregi. Pod koniec życia Mao Zedonga liczyła ok. 100 mln, obecnie ponad $320 \mathrm{mln}$ robotników, plus ok. $280 \mathrm{mln}$ robotników sezonowych (chłopo-robotników).

W następstwie tych procesów powstały głębokie różnice w kierownictwie partyjnym na temat bazy partyjnej i jej roli w KPCh i w państwie. Prywatyzacja i możliwości wchodzenia w szeregi KPCh biznesmenów i prywaciarzy osłabiły robotniczy charakter partii i wpłynęły na osłabienie roli klasy robotniczej w życiu społeczno-politycznym i stało się przyczyną wewnątrzpartyjnego fermentu i krytyki. Faktycznie od pewnego czasu obserwuje się w KPCh pęknięcie i podział bazy partyjnej, co znalazło wyraz do Mao Zedonga w spuścinie ideowo-politycznej. Doszło nawet do głębo- 
kiego pęknięcia na najwyższych szczeblach władzy, kiedy ważyły się losy nowego kierownictwa KPCh po kończącej się kadencji Hu Jintao w 2012 r. Pojawiła się wtedy kandydatura Bo Xilaia, wpływowego sekretarza silnej organizacji w Chongqing - wielkim ośrodku miejsko-prowincjonalnym w środkowych Chinach, wcześniej ministra handlu w rządzie centralnym, który określany był jako „kontynuator linii Mao". Jak wiadomo Bo Xilai przegrał tę rywalizację z Xi Jinpingiem, został oskarżony o wielką korupcję, a jego dalsze losy były mało pocieszające.

Bo Xilai odwoływał się do rewolucyjnego życiorysu i legendy Mao Zedonga, jego skromności i dbania o interesy zwykłych ludzi, umiejętności nawiązywania bezpośrednich kontaktów z ludźmi pracy, w czym było wiele przesady. Te różnice odzwierciedlały wpływy dawnych "partyjnych nostalgików", najbardziej poszkodowanych lub nawet mało zyskujących na reformach gospodarczych. Formalnie stawiali oni hasło konieczności powrotu do polityki, a właściwie stylu propagandy Mao, co w praktyce było niemożliwe w sytuacji zmian epoki i konieczności rozwiązywania olbrzymich potrzeb Chin nie w oparciu o praktykę izolacji i autarkii wielkiego kraju, lecz konieczności szerokiego otwarcia na kooperację z kapitałem zagranicznym, ale na warunkach chińskich.

O ile "nostalgicy” za Mao Zedongiem żądali powrotu (tylko) do "czasów Mao", to dalej idące żądania stawiali rzecznicy „pluralizmu w KPCh”, którzy na pierwszym miejscu stawiali rezygnację z zasady kierowniczej roli Komunistycznej Partii Chin, pod hasłem powiązanym z odłamem chińskich gorbaczewistów. Oba te nurty były wpływowe w okresie demonstracji studentów na Placu Niebiańskiego Spokoju, szczególnie w kwietniu-czerwcu 1989 r., kiedy 
ważyły się losy nie tylko reform Denga, ale w ogóle socjalizmu w Chinach. Te odśrodkowe tendencje i wręcz jawne dążenia kapitalistyczno-ustrojowe zostały przezwyciężone, demonstracje rozpędzono siłą, nowe kierownictwo na czele z Deng Xiaopingiem otrzymało silny mandat polityczny i Chiny realizują program jego reform. Obecnie od 2012 r. nowe kierownictwo na czele z Xi Jinpingiem kontynuuje ten trend, co podkreślono na XVIII Zjeździe KPCh w 2012 r. i XIX Zjeździe w 2017 r., na którym m.in. umocniono pozycję ustrojowo-polityczną nowego przywódcy, dając mu prawo sprawowania władzy bez ograniczeń do dwóch kadencji.

Mao Zedong i jego myśl są w dalszym ciągu obecni w życiu ideowo-politycznym Chin, o czym świadczy wielki szacunek, jakim otacza się jego pamięć i zasługi wielkiego rewolucjonisty dla chińskiego ludu. Wraz z wdrożeniem reform nie został on odrzucony i zapomniany (tak jak Stalin w Rosji po 1953 r., a szczególnie po 1956 r. przez nowych przywódców KPZR), a jego myśli są przedmiotem wykładów i analizy nie tylko w szkołach partyjnych, także na uniwersytetach. Mimo popełnionych błędów Komunistyczna Partia China w trakcie długotrwałej debaty wewnątrzpartyjnej oceniła, że 70\% życia wielkiego rewolucjonisty były chwalebne i jego zasług dla ludu chińskiego nie należy zapominać i przekreślać. 30\% było błędami, szczególnie w schyłkowych latach, które nie wpływają znacząco na ocenę życiowego dorobku wielkiego rewolucjonisty.

Do tych ocen nawiązują maoistowscy „nostalgicy”, którzy jeszcze w 2012 r., dzielili się na dwie podgrupy. Jedna stała po stronie nowego polityczno-reformatorskiego kursu, domagając się tylko zmian kosmetycznych. Druga podgrupa domagała się „nowej czystki partyjnej”, innym hasłem było „zwalczanie amerykańskiego imperializmu” i konieczności 
dalszego „trzymania się socjalistycznej drogi”. Obie tendencje były nie do utrzymania przez nowe kierownictwo pod wodzą nowego sekretarza generalnego Xi Jinpinga, jednocześnie ułatwiały lawirowanie i wygrywanie różnic dla umacniania nowego kursu KPCh. Poparcie dla „nostalgików" wiązało się z negacją reform Denga Xiaopinga i prowadziłoby do gospodarczej katastrofy. Natomiast poparcie dla „dogmatyków” byłoby wycofaniem się partii na pozycje izolacjonizmu, a w szczególności na arenie międzynarodowej i w konsekwencji mogłoby prowadzić do awanturnictwa w kategoriach polityki międzynarodowej.

Podstawą i oparciem kadrowym dla Xi Jinpinga jest licząca prawie 650 tys. armia kadry kierowniczej, będąca swoistym stosem pacierzowym systemu politycznego i ta armia jednoznacznie udzieliła poparcia nowemu kierownictwu w 2012 r. i potwierdziła je zdecydowanie na ostatnim zjeździe partii w 2017 r. i obecnie nic nie wskazuje, by ta pozycja ta uległa osłabieniu. Xi Jinping ma silny mandat umocniony zniesieniem ograniczenia zasady dwóch kadencji, co oddaliło niebezpieczeństwo podziału, a nawet rozbicia partii. Ale w dalszym ciągu pozostaje otwarty problem stosunku bazy partyjnej do kierownictwa, o czym świadczy nadal niski współczynnik członkostwa robotników w KPCh. Bez wątpienia jest to problem o znaczeniu strategicznym dla partii i tak jest definiowany przez jej sekretarza generalnego, który w szczególności na XIX Zjeździe KPCh w 2017 r. podkreślał jej marksistowski i robotniczy charakter oraz konieczność ideowego i politycznego ożywienia podstawowych organizacji partyjnych w zakładach przemysłowych, szczególnie w przedsiębiorstwach kapitału prywatnego.

Ważnym zagadnieniem, które w ostatnich latach dzieli partię jest rosnąca różnica, a nawet przepaść między sta- 
rymi i nowymi członkami KPCh, które odzwierciedlają się w poziomie wykształcenia: wysoko kwalifikowani z dyplomami szkół wyższych - nisko kwalifikowani na poziomie szkół podstawowych i średnich, w zarobkowaniu: branże wymagające intensywnego techniczno-naukowego przygotowania - branże intensywne fizyczno-robotnicze, a także pod względem miejsca pracy: miasto-wieś. Powstałe i rosnące duże różnice dochodowe między warstwą wysoko wykształconych a słabiej wykształconych pogłębiły różnice między nowymi a starymi członkami partii i pogłębiły poczucie nierówności. Na to nakłada się nierówny dostęp do bogactwa społecznego i ekspansywny rynek i wszechobecna reklama, lansująca często pasożytniczy sposób życia made in USA. W czasie reformowania gospodarki powstały olbrzymie fortuny niektórych członków KPCh, jak Wang Jianlin - założyciel grupy kapitałowej WANDA, Ren Zhenfei grupy HUAWEI i Ren Zhanjiang - Grupa Nieruchomości - TYCCON, których majątek oceniany jest na wiele setek milionów dolarów; jednocześnie miliony zatrudnionych $\mathrm{w}$ przedsiębiorstwach państwowych utraciły pracę.

W wyniku tych przemian pojawiły się nowe grupy społecznego ubóstwa, a nawet żyjących w ekstremalnej nędzy, które ponownie różnicują nie tylko społeczeństwo, także KPCh. Zdaniem ekspertów powstały dwa główne zagrożenia: 1 . W łonie rządzącej elity podziały pogłębiają się i w partii trwa rywalizacja, a nawet skrywana walka nie tylko o wpływy, ale o władzę. 2. Baza partyjna czuje się zmarginalizowana, w związku z tym chińscy politolodzy Zhu Juwei i Xiang Zeni podzielili członków partii na pięć grup (warstw): 1. grupa rządząca, obejmuje czołowe kadry w organizacjach partyjnych i organach państwowych wszystkich szczebli, ma ona decydujące wpływy; 2. elita gospodarcza, 
w tym podmioty decydujące $\mathrm{w}$ przedsiębiorstwach sektora państwowego i właściciele prywatnych przedsiębiorstw, mających dostęp do zasobów gospodarczych i dobre układy z grupą rządzącą, ciesząca się wielkimi wpływami; 3. Elity naukowo-edukacyjne, wybitni intelektualiści, profesorowie szkół wyższych, bossowie instytucji kształtowania opinii publicznej, mający wpływ na politykę i na partię pod warunkiem, że są akceptowani przez obie wyżej wymienione grupy; 4. grupa tzw. „obserwatorów” - urzędnicy, fachowi robotnicy, nauczyciele itd. Ich wpływ ogranicza się do udziału w wyborach partyjnych i wyrażaniu zgody dla linii partyjnej; 5. dolna grupa - biedni chłopi, dawni pracownicy sektora państwowego, robotnicy sezonowi i inni. Praktycznie nie mają żadnego prawa współdecydowania i nie mają żadnego wpływu w partii ${ }^{15}$.

Jeśli wziąć pod uwagę statystykę członkowską KPCh z 2016 r. i porównać ją z wyżej wymienionymi pięcioma grupami, to piąta, najniższa grupa stanowi $66,2 \%$, a czwarta grupa 25,2\% ogółu członków partii. Oznacza to, że więcej niż 90\% członków KPCh nie ma żadnego znaczącego politycznego wpływu. Wymienieni politolodzy są zwolennikami rosnącego centralizowania władzy politycznej i zasobów gospodarczych i wyrażają interesy nieformalnych grup interesów, a raczej wewnątrzpartyjnych klik politycznych, których celem było zapewnienie sobie określonych przywilejów i ich zabezpieczenie.

Zdecydowaną walkę przeciwko korupcji i systemu patronackiemu w partii wydał nowy sekretarz generalny $\mathrm{KC}$ KPCh Xi Jinping, który m.in. nakazał wdrożenie postępowania przeciwko byłemu członkowi Stałego Komitetu

15 Por. ibidem, s. 62. 
Biura Politycznego KPCh Zhou Yongang, patronującemu m.in. należącego do państwa przemysłu petrochemicznego. Innym przykładem takiej wewnętrznej partyjnej kliki był były kierownik Kancelarii KC KPCh Ling Yihua. Ten miał założyć „regularne ziomkowskie zjednoczenie”, składające się z kadr przywódczych kręgów centralnego aparatu partyjnego i kręgów biznesowych, którzy regularnie spotykali się i załatwiali obsadzanie funkcji politycznych oraz lukratywnych interesów ekonomicznych.

Z badań wymienionych profesorów wynika, że dwie najniższe grupy zostały zepchnięte na margines. Ich zaufanie do najwyższego kierownictwa partyjnego spadło i uległo zachwianiu, a ich lojalność wobec partii osłabiona. Odzwierciedlało się to też we wzroście bierności wielu członków partii i ich odmowie w zaangażowaniu się w sprawach partyjnych. Te niebezpieczeństwa dostrzegło obecne kierownictwo, które sięgnęło do metod z epoki Mao Zedonga, odgrzebało m.in. hasło „przestrzegać linii partii”. Członkowie partii zostali zobowiązanie nie tylko popierać „linię mas”, ale także publicznie jej bronić i aktywnie występować przeciwko tym, którzy wątpią w nią, osłabiają, a nawet negują ${ }^{16}$.

W 2016 r. około $20 \mathrm{mln}$ ludzi ubiegało się o przyjęcie w szeregi KPCh, z tego uwzględniono tylko 1,91 mln, czyli około 9\%, a więc dostać się d KPCh nie jest łatwo, w sytuacji gdy wśród młodzieży rośnie liczba chętnych. W latach 2005-2012 liczba nowych członków corocznie wzrastała, a od 2013 r. systematycznie maleje. Nowe kierownictwo zaostrzyło kryteria przyjęcia do partii i chce mieć w swych szeregach więcej robotników. Poprzednie kierownictwo na czele z Hu Jintao, który w młodości był przewodniczącym Komuni-

16 Ibidem, s. 63. 
stycznego Związku Młodzieży, otworzyło szeroko bramy partii dla nowych młodych członków. W 2011 r. przyjęto ich 3 mln. Zmiana kierownictwa w 20212 r. i objęcie funkcji sekretarza generalnego przez Xi Jinpinga zmieniło tę politykę. Kierownictwo uznało, że polityka ta prowadziła do osłabienia ideowo-politycznego partii, gdyż przyjęcia były często formalnością. Xi Jinping był także przed 2012 r. członkiem Biura Politycznego i odpowiedzialnym m.in. za budownictwo partyjne, jednocześnie pełnił funkcję rektora Centralnej Szkoły Partyjnej. Działalność na tych odcinkach dostarczyła mu wiele doświadczenia i wiedzy o niedostatkach masowego naboru do partii i konieczności uzdrowienia niedobrych zjawisk, a może nawet przeprowadzenia jakiejś czystki.

Podstawowym celem nowego kierownictwa stało się podniesienie na wyższy poziom autorytetu partii, w związku z tym zwiększone zostały także wymagania w zakresie rekrutacji nowych członków, m.in. w 2013 r. w dokumencie Centralnego Wydziału Organizacyjnego KC KPCh po raz pierwszy określono kwotę przyjęć do 2020 r. na nie więcej niż 1,5\% rocznie. W 2016 r. wartość tę zmniejszono nawet do $0,8 \%$. Wtedy przyjętych zostało 1,3 mln mniej członków niż w 2012 r. (3, 23 mln). W 2013 r. wymogi tego dokumentu zostały jeszcze bardziej wzmocnione przez nowe podstawy rekrutacji członków w nowej sytuacji. W dokumencie zwracano szczególną uwagę na "pozyskiwanie przedstawicieli nowych warstw społecznych", co rozwinięte zostało w kolejnym dokumencie z 2014 r. W tym ostatnim zwracało się szczególną uwagę na "awangardowość” i „czystość” (ideowo-polityczną). Ubiegający się muszą być przekonani i wierzyć w marksizm oraz socjalizm o chińskiej specyfice i socjalistyczny system wartości oraz je dobrowolnie praktykować. Jest to wyrazem zmian nowego kierownictwa 
oraz oczekiwań pożądanych postaw członków partii. Jest to wyraźny sygnał kierownictwa partii, że partia nie jest tylko organizacją polityczną, ale także ideową, w której socjalistyczna ideologia jest podstawą jedności ideowej KPCh. Xi Jinping i nowe kierownictwo dążą do większego zjednoczenia ideowego i umocnienia politycznego szeregów partyjnych w obliczu nowych, wielkich zadań, przed którymi stoi Chińska Republika Ludowa i cały świat ${ }^{17}$.

Komunistycznej Partii Chin przyświecają także ambicje reprezentowania nowych warstw społecznych. Od XVI Zjazdu (2002 r.) partia otwarła się także na prywatne przedsiębiorstwa, co przyniosło wielki rozwój w organizacjach partyjnych w sektorze niesocjalistycznym. Było to nowe zjawisko w stosunkach ze spółkami kapitalistycznymi, które na masową skalę rozwijały się już od dłuższego czasu. Kwestia dotyczyła dwóch różnych sytuacji:

1. przedsiębiorstw prywatnych chińskiego kapitału, które były bardziej skłonne na obecność i działalność nie tylko związków zawodowych, ale także organizacji zakładowych KPCh, tym bardziej w zakładach dawniej państwowych, które były prywatyzowane;

2. przedsiębiorstwa zakładane przez obcy kapitał z USA, Kanady, państw europejskich, Japonii, Korei Południowej itd., które nie tolerowały sytuacji, żeby w ich rodzimych fabrykach mogli się organizować i działać komuniści, ew. godzili się na założenie związku zawodowego.

Problem polegał jednak na tym, że Chińska Republika Ludowa otwierając się na penetrację obcego kapitału zastrzegała warunek wolności działania nie tylko związków zawodowych, ale również organizacji partyjnych KPCh.

17 Por. ibidem, s. 64. 
Zgodnie ze Statutem KPCh, jeżeli w zakładzie było przynajmniej trzech członków partii mogli założyć oni własną, samodzielną podstawową organizację.

W tym zakresie KPCh osiągnęła dużo sukcesów. Według niepełnych danych między 2006-2016 liczba organizacji partyjnych w sektorze prywatnych, $\mathrm{w}$ tym w przedsiębiorstwach zagranicznego kapitału wzrosła do 1,8 mln (dziewięć razy). Oznaczało to także wzrost "nowych warstw socjalnych” w szeregach KPCh, przy czym sytuacja była zróżnicowana. Inaczej kwestia prezentowała się $\mathrm{w}$ byłych państwowych zakładach, gdzie występowały wcześniej aktywnie działające organizacje KPCh. Natomiast trudniejsza była sytuacja w powstających od nowa zakładach, których właściciele nie życzyli sobie jakiejkolwiek działalności nie tylko partyjno-politycznej, także związkowej i robili wszystko, by do niej nie dopuścić. Ustępowali dopiero pod naciskiem wysokich czynników, że w ChRL musi być respektowana Konstytucja, chińskie prawo pracy i normy Kodeksu pracy.

Badania socjologiczne przeprowadzone w prowincji Guangdong (Kanton) dowodziły, że przedstawiciele nowych socjalnych warstw otrzymywali ponadprzeciętne dochody, reprezentowali wysoki poziom wykształcenia i w związku z tym wyższy poziom świadomości swych praw i przykładali więcej wartości „sprawiedliwości społecznej”. Wyrażali duże zainteresowania polityką i czuli się mocno związani ze swą ojczyzną, ale niekoniecznie z Komunistyczną Partią Chin. Ich gotowość do podjęcia aktywności politycznej była duża, ale organizacyjnie wiązała się bardziej w radach (Kongresach Ludowych) lub w Komisji Konsultacyjnej chińskiego ludu (frontu narodowego), które skupiały nie tylko członków KPCh. Unikano deklaracji podejmowania aktywności w KPCh i tu pojawiło się niebezpieczeństwo kształtowania 
się burżuazyjnej ideologii ustrojowej i niebezpieczeństwo kształtowania się burżuazyjnej opozycji. Omawiana kwestia budziła też liczne kontrowersje wśród kręgów najwyższego kierownictwa partyjnego. Wielu starych członków partii wyrażało swój sceptycyzm wobec przyjmowania do partii nowych elit. Widzieli oni duże różnice socjalne i oceniali je jako szkodliwe dla klasowej jednolitości bazy partyjnej. Elity z prywatnego sektora nie demonstrowały otwarcie braku swojego zaufania do KPCh. W badaniach podstawowych organizacji KPCh w Szanghaju ponad 2/3 badanych określało stosunek do przedsiębiorców jako „napięty”. Ich próby podejmowania kontaktów z przedsiębiorcami napotykały często na odmowę lub odrzucenie.

Kwestie te były znane kierownictwu partyjnemu, informacje do centrum napływały ze wszystkich kierunków, w związku z tym nowe kierownictwo zdecydowało się na zmianę taktyki i na uruchomienie pośrednich form aktywizacji nowych warstw. W 2016 r. utworzono Biuro ds. „Nowych Warstw Społecznych", które było odpowiedzialne za utrzymywanie kontaktów między KPCh i prywatnymi przedsiębiorstwami. Partia oczekiwała, że dzięki tym bardziej zinstytucjonalizowanym formom aktywności uda się tę niejednolitą zbiorowość lepiej kontrolować i zintegrować z istniejącymi strukturami. Z tych informacji można wyciągnąć wniosek, że problem nowych warstw społecznych w KPCh przestał być palący i został pomyślnie rozwiązany z korzyścią dla partii ${ }^{18}$.

$\mathrm{Na}$ odrębną uwagę zasługuje kwestia udziału kobiet w Komunistycznej Partii Chin. W 2016 r. tylko 1/4 członków KPCh było kobietami, w 2019 r. relacja ta nie poprawiła się, na 91,9 mln członków KPCh 25,6 mln były towa-

18 Por. ibidem, s. 65. 
rzyszkami. KPCh od wielu wcześniejszych lat wyrażała troskę z powodu małego zaangażowania kobiet w partii, co było nie tylko charakterystyczne dla KPCh, także szerzej jeśli chodzi o działalność publiczną. Problem był żywo dyskutowany w Komitecie Centralnym już w 1995 r., kiedy w Pekinie odbywała się Światowa Konferencja ONZ nt. Nierówności Praw Kobiet i konieczności zwiększenia udziału kobiet w życiu społecznym. W 2001 r. w Wydziale Organizacyjnym KC KPCh opracowano na ten temat dokument, w którym m.in. zobowiązano struktury partyjne, by w ciągu roku zwiększać liczbę kobiet w partii o $1-2 \%$. W gremiach kierowniczych powinna znajdować się co najmniej jedna towarzyszka, co sygnalizowało bardzo niski udział kobiet w tych gremiach. Podobny postulat promowany był w organach przedstawicielskich i wykonawczych na wszystkich szczeblach władzy, a jeśli chodzi o rząd ChRL stawiano postulat udziału kobiet nawet do połowy jego składu.

Realizacja tych postulatów udała się tylko częściowo, kobiet w gremiach kierowniczych partii i państwa jest coraz więcej, ale norma 50-50\% jest nadal postulatem dalekiej przyszłości. Aktualna relacja kobiety - mężczyźni w gremiach kierowniczych prezentuje się najczęściej jak 1:10, np. w komitetach partyjnych prowincji, w których na 290 mężczyzn występowało w 2016 r. tylko 29 kobiet. W obecnym, po XIX Zjeździe Biurze Politycznym KC KPCh są tylko 2 kobiety obok 23 mężczyzn. W Stałym Komitecie Biura Politycznego, czyli najwyższym organem operacyjnym polityki Chin liczącym siedmiu członków, nie ma ani jednej kobiety. Także wśród 31 pierwszych sekretarzy Komitetów Prowincjonalnych nie ma ani jednej kobiety. Lepiej wygląda sytuacja w rządach prowincji, na ogółem 187 ministrów prowincjonalnych było 14 kobiet (około $8 \%$ ). Na stanowi- 
skach Gubernatorów prowincji były dwie kobiety. W randze ministrów rządu centralnego na 161 osób było 16 kobiet (10\%), a w 10-osobowym Prezydium Rządu jest tylko jedna kobieta (10\%). Udział kobiet w Komitecie Centralnym KPCh 18. kadencji było reprezentowanych $8,8 \%$ kobiet, co oznaczało spadek z poprzednim zjazdem o $1,2 \%$.

Ogólnochiński Związek Kobiet przyjął dyrektywę stałej nowej kwoty w partyjnych gremiach kierowniczych i państwowych w miejsce wcześniej przyjętej liczby jednej kobiety, która w praktyce traktowana była jako górna wytyczna, ale nie przyniosło to większych zmian. Podczas ostatniego XIX Zjazdu Partii w 2017 r. niewiele się pod tym względem zmieniło. Zdaniem Zheng Li - analityka z Instytutu Badawczego Brooking z USA niski udział kobiet w życiu politycznym jest konsekwencją generalnie niższego wykształcenia kobiet. Wydaje się jednak, że nie jest to jedyna przyczyna. W Chinach nie zostały przezwyciężone stare konstancjańskie zasady, że w życiu nie tylko publicznym pierwszeństwo mają mężczyźni, a miejsce kobiety jest w domu i rodzinie ${ }^{19}$.

Od 2012 r. wraz z dojściem do władzy Xi Jinpinga i jego grupy nowe kierownictwo KPCh próbuje na nowo ukształtować politykę naboru nowych członków i wewnętrznej struktury KPCh. Przede wszystkim podniesiono wymogi i kwalifikacje profesjonalne i ideowo-polityczne jako kryterium przyjmowania nowych członków. Zrezygnowano z masowości na rzecz jakości, co wpłynęło na poprawę stanu kwalifikacji nowych członków i wzrost dyscypliny partyjnej, a także stało się instrumentem zwalczania i ograniczania korupcji m.in., przez na nowo reaktywowaną publiczną samokrytykę, jak i deklarowanie lojalności wobec partii. Podjęte

19 Ibidem, s. 66. 
środki dyscyplinujące nie przyniosły jednak oczekiwanych rezultatów w zakresie ograniczenia pluralizacji bazy partyjnej, jak i pogłębiania różnic, a nawet przepaści między bazą partyjną a warstwą kierowniczą partii. Nowe kierownictwo dąży do jednostronnego umocnienia hierarchii partyjnej, a nie do współokreślania, a nawet współdecydowania ze strony bazy członkowskiej partii. Rodziło to i rodzi różnego rodzaju napięcia wewnętrzne, a nawet wewnątrzpartyjne konflikty, przed czym m.in. ostrzegał ekspert Mercator Institute for China Studies ${ }^{20}$.

Kwestię tę przybliżają następujące dane w poniższej tabeli.

Tabela. Zmiana struktury członkowskiej KPCh

\begin{tabular}{|l|r|r|}
\hline \multicolumn{1}{|c|}{ Lata } & 2017 & 2019 \\
\hline Ogólna liczba członków (w mln) & 89,6 & 91,9 \\
\hline Kobiety & 23,9 & 25,6 \\
\hline Mniejszości narodowe & 6,5 & 7,4 \\
\hline Członkowie z wykształceniem fachowym i wyższym & 43,3 & 48,3 \\
\hline Robotnicy & 6,7 & 6,4 \\
\hline Chłopi, pasterze, rybacy & 25,5 & 25,5 \\
\hline Technicy i usługodawcy & 13,6 & 14,4 \\
\hline Przedsiębiorcy i ich organizacje & 9,5 & 10,1 \\
\hline Urzędnicy & 7,1 & 7,7 \\
\hline Uczniowie i studenci & 1,8 & 2,0 \\
\hline Renciści i emeryci & 17,5 & 18,7 \\
\hline
\end{tabular}

Źródło: Wydział Organizacyjny KC KPCh, podane za: J. Geppert, op.cit., s. 67-68.

Z wyżej wymienionych danych i analizy wynika, że w ostatnich ponad trzydziestu latach liczba członków partii niemal się podwoiła i liczy prawie $92 \mathrm{mln}$ członków. Tylko w okresie 2005-2016 zwiększyła się o 26\%. Jednocześnie

20 Por. „China Monitor” 19.07.2017, za ibidem, s. 67) 
zmieniła się struktura członkowska, co znajduje głównie wyraz w rosnącym rozwarstwieniu, podziałach socjalnych i postępującą pluralizacją społeczeństwa chińskiego, w szczególności w aspekcie stylu życia, wykształcenia i sytuacji majątkowej, co wpływa na wzrost niejednolitości socjalno-klasowej KPCh. W szczególności godny odnotowania jest spadek liczby robotników w strukturze partyjnej z 6,7 mln do 6,4 mln, a jednocześnie systematyczny wzrost prywatnych przedsiębiorców z 9,5 mln do 10,1 mln. Tak więc relacja robotnicy - kapitaliści w partii wyraźnie przechyliła się na korzyść kapitalistów, nie tylko w kategoriach potencjalnego wpływu na politykę partii, ale także w kategoriach liczbowych. Kierownictwo KPCh pod wodzą Xi Jinpinga dostrzega te zagrożenia i poczynając od 2012 r. stara się przeciwdziałać negatywnym tendencjom, zaostrzając kryteria przyjmowania nowych członków oraz wyraźnie ograniczając liczbę nowych przyjęć. Szczególną wagę zwrócono na prywatne sektory przedsiębiorstw kapitału zagranicznego, w których w przeciągu ostatnich dziesięciu lat założono 1,8 mln nowych organizacji KPCh. W ten sposób znaleziono dość skuteczny sposób przenikania i penetracji nowych warstw socjalnych, jak i ponownie tworzącej się klasy kapitalistów, a więc prywatnych przedsiębiorców, samodzielnych w sektorze usług, serwisantów itp. nowych grup socjalno-zawodowych. Jest to bez wątpienia duży sukces nowego kierownictwa, ale zdaniem zachodnich ekspertów zbyt powolny. Oczywiście krytycznie na to patrzą przedstawiciele rewolucyjnych partii komunistycznych, oskarżając KPCh o schodzenie na pozycje rewizjonistyczne i zdradę ideałów komunistycznych.

Podczas kiedy kierownictwo dąży do szybkiej organizacyjnej jedności i politycznej zwartości, a nawet homogeniczności partii, baza partyjna, jeżeli chodzi o jej skład, 
interesy polityczne i ideologiczne preferencje pozostaje nadal niejednolita, a nawet się pogłębia. Te różnice były jak dotychczas skrywane i oficjalnie kierownictwo prezentuje się jako konsekwentnie zachowujące i realizujące interesy całego świata pracy, ale analiza wyżej wymienionych danych przeczy wyraźnie tym deklaracjom ${ }^{21}$.

W ciągu ponad siedemdziesięciu lat Chińska Republika Ludowa radykalnie zmieniła na korzyść sytuację ekonomiczną i socjalną społeczeństwa. Świadczą o tym wielkie liczby i jakościowe epokowe przemiany cywilizacyjne i ustrojowe. Chiny w 1949 r., kiedy startowały jako Chińska Republika Ludowa, należały z 54 dol. dochodu na głowę ludności do najbiedniejszych państw świata. Ponad 80\% ludności stanowili biedni chłopi, najczęściej bez ziemi, pracownicy dniówkowi i wędrowni robotnicy. Robotnicy przemysłowi w wielkich miastach stanowili około $3 \mathrm{mln}$, co stanowiło około 1,5\% zatrudnionych. Dotychczasowy rozwój można podzielić na dwa duże okresy:

1. 1949-1978 (30 lat);

2. 1979-2020 (41 lat).

Oba okresy charakteryzowały się dynamicznym wzrostem, ale inne były uwarunkowania wewnętrzne i międzynarodowe. Pierwszy związany był z przywództwem Mao Zedonga, drugi z przywództwem Deng Xiaopinga i jego następców. Pierwszy okres charakteryzował się rewolucyjnymi zmianami, rozwiązał liczne sprzeczności społeczno-gospodarcze, odziedziczone po wcześniejszych epokach i Chiny uczyniły olbrzymi krok naprzód w dziele budowy podstaw socjalizmu. Pozostawały pod silnym wpływem osobowości Mao Zedonga i jego rozumienia i rozwoju marksizmu w wa-

21 Por. ibidem, s. 69. 
runkach rozwoju chińskiej cywilizacji, co nawet stało się podstawą do definiowania ustroju ChRL jako "agrarnego socjalizmu”, „chińskiego socjalizmu”, „chińskiego marksizmu” lub nawet „maoizmu”. Jednocześnie Mao Zedong nie odrzucał podstawowych tez i wartości marksizmu, ale starał się nadać mu chińską formę i wykorzystać chińskie doświadczenie. Był dla Chin Leninem i zarazem Stalinem, a więc odegrał dużą rolę w przeszczepieniu marksizmu i leninizmu na grunt chiński, a jednocześnie rozwijał go na gruncie starej i bogatej chińskiej cywilizacji i wdrażał jego podstawowe wartości oraz zasady w życiu gospodarczym, społecznym, politycznym i kulturalnym. Nie był bez wad i słabości, które dały o sobie znać po ważnych błędach popełnionych głównie w schyłkowych latach życia wielkiego rewolucjonisty.

Drugą wielką postacią był Deng Xiaoping, jeden ze współzałożycieli Komunistycznej Partii Chin, człowiek niezwykle utalentowany, znakomity organizator, dowódca wojskowy, działacz partyjny „pierwszego kręgu”, przez wiele lat sekretarz generalny KPCh i jeden z najbliższych współpracowników Mao Zedonga. Jednocześnie od wczesnych lat publicznej działalności dostrzegający inne aspekty życia i walki politycznej niż Mao Zedong, co później doprowadziło do niejawnej rywalizacji, oskarżenia go o frakcyjność, a nawet rozejścia się dróg obu wielkich chińskich marksistów. Na odmienność Denga wpływała jego droga życiowa. Jako młody chłopiec był jednym z pierwszych rewolucjonistów, który wyjechał na dłuższy okres do Francji, później do Niemiec i Związku Radzieckiego, żeby uczyć się nie tylko zawodu i przypatrywać się ludziom Zachodu, ale jednocześnie wyciągać wnioski dla poprawienia wielkiej niedolo chińskiego ludu. Był jednym z pierwszych, który zerwał $\mathrm{z}$ dominującym $\mathrm{w}$ tradycyjnych Chinach poglądem o „wyż- 
szości chińskiej cywilizacji”. Studiował z uwagę przyczyny rozwoju kapitału i walki proletariatu europejskiego. Z tych nauk wyciągał wnioski dla Chin i KPCh, które później pogłębiał na Uniwersytecie Sun Jat-sena (Narodów Wschodu) i szkołach międzynarodówki komunistycznej w Moskwie. Jednym słowem Deng znał świat kapitalistyczny z autopsji i jego analizy naukowej. Widział w nim nie tylko zagrożenia kolonialne, ale olbrzymią przewage gospodarczą, technologiczną i militarną, co później legło u podstaw jego polityki szerokiego otwarcia Chin na świat, ale nie na zasadach podległości, jak w relacjach między metropoliami oraz koloniami, ani formach podległości charakterystycznej dla neokolonializmu po II wojnie światowej.

Legło to u podstaw jego koncepcji socjalistycznej gospodarki rynkowej jako kontynuacji chińskiej drogi do socjalizmu w nowej epoce. Jednocześnie Deng Xiaoping dostrzegał, że Chiny po trzydziestu latach budowy podstaw socjalizmu, choć osiągnęły olbrzymie postępy mają małe szanse przezwyciężenia licznych niedostatków nie tylko ekonomicznych bez pomocy z zewnątrz. Stosunki ZSRR z KDL-ami w Europie od lat 60. ubiegłego wieku zaczęły się psuć, co prowadziło także w tej sferze do większej izolacji Chin. Jedynym wyjściem było nawiązanie szerokiej współpracy z kapitałem zagranicznym. Chiny dysponowały wielkimi atutami, a więc olbrzymią tanią siłą roboczą, wielkim rynkiem i bogactwami naturalnymi. Kapitał zagraniczny i główne ośrodki burżuazyjne obawiały się komunizmu w Chinach, ale mając na uwadze łatwość wygrania niedawnej rywalizacji z ZSRR i upadku realnego socjalizmu w Europie uważały, że jeszcze łatwiej będzie z KPCh i Chińską Republika Ludową. Jak się później okazało, bardzo się w tych prognozach przeliczyły. KPCh, decydując się na 
reformy i otwarcie, „nie wylała dziecka z kąpielą”, zmieniła taktykę, ale nie strategię budownictwa socjalistycznego. Dowodzą to rezultaty ostatnich więcej niż czterdziestu lat, przy czym są uboczne koszty tej polityki, które wymagają wyeksplikowania i analizy.

Bez wątpienia Chiny zmieniły się gruntownie w kategoriach potencjału gospodarczego mierzonego wskaźnikami PKB. Oficjalnie są na drugim po USA miejscu, co jest mierzone w dolarach, ale jeśli mierzyć w juanach i ich sile nabywczej są na pierwszym miejscu w świecie. W $2021 \mathrm{r}$. ich PKB wynosiło 14 bln dol., mierzone w juanach 21 bln dol. Oczywiście są to dane przybliżone i bardzo uproszczone, rozumiejąc sposób obliczania PKB jako sumę rocznych wartości gospodarki. Poza tym między obu gospodarkami jest głęboka różnica w strukturze. W Chinach zdecydowaną przewagę mają przemysł i usługi, w USA głównie usługi, także inne kwestie, np. problemy wsi, rolnictwa i zatrudnienia w rolnictwie, bezrobocia, dostęp do wykształcenia, zdrowie i higiena społeczna, długość życia, dostęp do lekarza itd. Jednocześnie wraz z napływem obcego kapitału i prywatyzacją gospodarki uspołecznionej w Chinach pogłębia się rozwarstwienie społeczno-klasowe. Można jednak z pełnym przekonaniem stwierdzić, że w wyniku reform gospodarczych poprawiło się życie wszystkich Chińczyków, ale nie w takim samym stopniu, a relatywnie te różnice mocno pogłębiają się. Ogromnie podniósł się poziom życia dla wąskiej grupy nowej burżuazji. Według danych Banku Światowego sprzed kilku lat w ciągu trzydziestu lat reform Chiny przekształciły się z państwa rozwijającego się, w którym bieda i głód doskwierały milionom na co dzień, w kraj, w którym przeciętny poziom dochodu osiągnął górną średnią granicę. Program rozwojowy Narodów Zjednoczonych opracował 
nowy indeks ludzkiego rozwoju (Human Development Index), którego głównymi współczynnikami są: 1. oczekiwana długość życia; 2. wykształcenie (lata); 3. zdrowie, który w Chinach w 2015 r. wzrósł do 0,738, dla porównania Niemcy 0,926 i który sytuował Chiny na 90. miejscu w świecie.

Podział dochodu w Chinach jest bardzo nierówny, co wyraża współczynnik Gini'ego, definiujący nierówność ChRL. W czasach Mao Zedonga wynosił on ok. 0,17, w 1980 r. wzrósł do 0,32, a w 2020 r. do 0,477, co sytuuje nierówność na poziomie USA lub Brazylii. W 2017 r. prywatny majątek Chin oceniany był na 27 tys. dol. na dorosłą osobę, było to nieco mniej niż w Niemczech, jednak znacznie wyżej niż w Japonii i Korei Południowej. W Chinach rośnie nieustannie liczba milionerów, a nawet miliarderów, których majątek liczy się w dol. USA, a nie w juanach, o czym wspomniano wyżej. Według Światowego Raportu Bogactwa w 2016 r. było w Chinach 719400 milionerów, a w 2020 r. 799 miliarderów, przy czym zdecydowana ich większość zamieszkuje w Hongkongu i Makao i duża ich część została odziedziczona po kapitalizmie i włączeniu b. kolonii pod koniec XX w. do Chińskiej Republiki Ludowej. W rankingu miliarderów Chiny przegoniły już nawet USA. Na marginesie zauważmy, że na całym świecie następuje głębokie rozwarstwienie majątkowe między biedą i nędzą a bogactwem i super bogactwem i problemu tej głębokiej nierówności, niesprawiedliwości społecznej raz braku podstawowego egalitaryzmu nie rozwiążą uczone Kasandry. Niezbędne są bowiem rozwiązania radykalne, nowe rewolucje społeczne i socjalistyczne. Bez nich światu grożą wielkie wojny, a nawet globalna katastrofa.

Rząd chiński od 1978 r. w związku z wdrożeniem socjalistycznej gospodarki rynkowej i propagowaniem socjali- 
zmu o chińskiej specyfice uznał, że egalitaryzm jest ważną wartością, ale główna sprzeczność Chin występuje między rosnącymi potrzebami ludu chińskiego a niskim poziomem rozwoju sił wytwórczych i ograniczonymi możliwościami, a nawet brakiem możliwości ich zaspokojenia. W związku z tym nie dążą do osiągania równości w dochodach i podziale bogactwa, uważając być może, że są to koszty postępu, które Chiny muszą zapłacić kapitałowi zagranicznemu jako swoisty haracz. Statystyki chińskie w porównaniach z rozwojem w innych państwach posługują się współczynnikiem ogólnego wzrostu i bogactwa liczonego według zasady osiąganego dochodu, tak jak to liczy się na Zachodzie. W ten sposób uzyskano liczbę 700 mln ludzi wyciągniętych z ekstremalnej nędzy w okresie 1949-2019, a średnie dochody są udziałem $400 \mathrm{mln}$ ludzi. Plany likwidacji nędzy w latach 2016-2020 podawały różne oficjalne dane rządu chińskiego, ok. 70 mln. J. Geppert podaje ${ }^{22}$, że w 2016 r. kategoria ta obejmowała 3,14\% społeczeństwa, a więc ok. 43,4 mln, a ostatnio autor chiński Fan Xiaodong podał liczbę 98,99 mln ludzi wyciągniętych z ekstremalnej nędzy ${ }^{23}$. Ekstremalna nędza liczona jest obecnie według statystyk ONZ, kiedy dochód na 1 dzień dla 1 osoby nie przekracza 2 dol. USA.

Innym współczynnikiem miary równości społecznej jest czynnik kosztów utrzymania. Jest to kwestia złożona ze względu na różnice w dochodach zarobkujących, różnice między miastem a wsią, a także regionami i prowincjami, a także sposób odżywiania, także liczba osób w rodzinie. Do 2017 r. w Chinach obowiązywała zasada jednego dziecka,

22 Zob. ibidem, s. 71.

23 Zob. Fan, Xiaodong, Chińska walka z ubóstwem, „Studia Orientalne". Wydawnictwo Adam Marszałek, Toruń 2021, nr 1 (19), s. 141. 
złagodzona na wsi do dwojga dzieci, jeśli pierwsze dziecko było płci żeńskiej. Zasada jednego dziecka nie była stosowana w stosunku do mniejszości narodowych i etnicznych. Obecnie także rodziny miejskie moga posiadać dwoje dzieci. W 2017 r. koszty utrzymania na rodzinę rozkładały się w przedziale między 80-800 euro na miesiąc, w zależności gdzie i jak rodzina żyła i jakie pożywienie spożywała. Na wsi sposób życia, koszty utrzymania i ceny artykułów są na ogół znacznie niższe niż w miastach. Ogólnie koszty artykułów spożywczych w Chinach są znacznie niższe niż np. w USA, Niemczech czy nawet w Polsce, natomiast droższe są produkty zagraniczne, jednak nie dotyczy to całego importu.

Kolejnym współczynnikiem są zarobki, także w tym przypadku kwestia jest złożona i ma liczne aspekty. Najniższe wynagrodzenie wprowadzone zostało w Chinach w 1990 r. i zostało ustalone nie w skali całego państwa, lecz w granicach poszczególnych miast i prowincji, w ustalaniu wysokości zarobków oraz warunków pracy liczy się opinia związków zawodowych. W ChRL obowiązuje zasada 8-godz. dnia pracy i 40-godzinnego tygodnia pracy, co reguluje ustawa, Kodeks pracy, a także zbiorowe układy pracy. Dopuszczalne są nadgodziny, które są extra płatne i nie może ich być więcej niż 36 godzin (w tygodniu). Oznacza to, że dzień pracy takiego pracownika zmuszonego warunkami ekonomicznymi do nadzwyczajnego wysiłku może trwać 14 godzin, włącznie $\mathrm{z}$ formalnie wolną sobotą (plus 6 godzin). Duża różnica występuje w zarobkach w miastach nadmorskich, obecnie także w Chinach centralnych, gdzie są znacznie wyższe, a zasadnicza między miastami a wsią (liczone średnio), gdzie są trzy razy wyższe. Najwyższy miesięczny zarobek osiągano się w 2017 r. w Szanghaju w przeliczeniu 6850 euro miesięcznie, najniższy - 280 euro. 
W biednej prowincji Qinghai najniższy zarobek wynosił 173 euro na miesiąc. Te zarobki należy realnie konfrontować ze znacznie wyższymi kosztami utrzymania w wielkich miastach, nie mówiąc o cenach rynkowych $1 \mathrm{~m}^{2}$ nowego mieszkania, porównywalnymi z cenami amerykańskich metropolii. Wspomniano o różnicach między dochodami mieszkańców miast i wsi. Według statystyk Państwowego Komitetu Statystycznego ChRL (NBS) w 2014 r. dochód per capita na wsi na 1 miesiąc wynosił średnio 8896 juanów, w miastach 26955 juanów, a średni dochód Chińczyka wynosił 18311 juanów, co przeliczano na 2767 dol. (1 dol . - ok. 6,5 juana). W 2017 r. - w miastach 27430 juanów, na wsi 9778 juanów. Najtrudniejsza jest sytuacja zarobkowa robotników sezonowych, ich przeciętny zarobek miesięczny wynosił w 2017 r. średnio 3456 juanów, co stanowiło mniej niż 500 dol. Ocenia się, że średnio połowę tej sumy przesyłają oni na potrzeby rodzin na wsi ${ }^{24}$.

Duże znaczenie w polityce płacowej w Chinach mają rosnące powoli, ale systematycznie zarobki i niski stopień inflacji, co utrzymuje dochody większości ludności na przyzwoitym poziomie i stosunkowo wysoki poziom optymizmu społecznego. Podwyżki płac, bonusy, premie, płatne godziny nadliczbowe mają duże znaczenie dla utrzymania w Chinach pokoju społecznego i wzrostu kupna towarów konsumpcyjnych, co jest zauważalne nie tylko w miastach, ale także na wsi. Jest to ważne źródło legitymizujące rolę KPCh od czasu wdrożenia reform i polityki wzrostu dochodów osobistych. W oparciu o analizę roli zarobków nie tylko w Chinach, ale także w innych państwach kapitalistycznych, można stwierdzić ich pewną zbieżność, np. w 1999 r. za-

24 Por. J. Geppert, op.cit., s. 72. 
robki w Niemczech były 36,5 razy wyższe niż w Chinach, w 2017 r. tylko trzy razy wyższe. Przeciętne realne stawki godzinowe w Chinach od 2006 do 2017 r. potroiły się i są wyższe niż w większości państw rozwijających się, jak i w niektórych państwach Unii Europejskiej. Oznacza to, że chińska polityka socjalna odchodzi od społecznych funduszy na rzecz ich prywatyzacji poprzez wzrost zarobków $\mathrm{i}$ indywidualnych form realizacji potrzeb socjalnych, wypoczynkowych, zdrowotnych itp.

W następstwie szybko i systematycznie zmniejsza się udział pracowników z niskimi dochodami. Jednocześnie wzrasta wykwalifikowana i wykształcona warstwa średnia (określana też jako klasa średnia), która obecnie jest znacznie większa niż liczba ludności USA (w 2020 r. - 400 mln). Kategoria „warstwa średnia” jest bardzo rozpowszechniona w USA jest to grupa ludzi, których dochody i własność nie mieszczą się ani w grupie bogatych, ani w grupie biednych i pozbawionych własności. Amerykańska Agencja McKinsey and Company definiuje ją jako mających roczne dochody między 10 tys. i 30 tys. dol. i prognozowała w Raporcie z 2013 r., że kategoria ta obejmie w Chinach do 2022 r. więcej niż 76\% ludności Chin. W 2012 r. grupa ta w liczyła 300 mln, w 2015 r. miała liczyć 53\% ludności, a niedawne oficjalne dane podawały liczbę $400 \mathrm{mln}$ ludzi ze średnimi dochodami. Innym wskaźnikiem rosnącego zróżnicowania majątkowego Chińczyków są oszczędności. W 2015 r. 109 mln Chińczyków miało oszczędności między 50 tys. a 500 tys. dol. Można więc stwierdzić, że chińska warstwa średnia jest największa na świecie i to zarówno pod względem dochodów, jak i posiadanych oszczędności. Według prognoz analityków z McKinsey and Company prognoza do 2022 r. przewiduje wzrost tej grupy do ponad 1 mld ludzi, 
której siła nabywcza będzie porównywalna (a może nawet wyższa) niż w USA i całej Unii Europejskiej.

Do tych prognoz potrzebne są kilka zdań komentarza. Po pierwsze, chińskie oficjalne dane z 2019 r. podawały, że liczba obywateli osiągających średnie zarobki wynosiła $400 \mathrm{mln}$, a więc była mniejsza od tych prognoz. Po drugie, należy zrelatywizować ekonomicznie podane wielkości czy 10 tys. dol. rocznie obejmuje tylko jednego konsumenta, czy też rodzinę. Jeśli podzieli się ten dochód średnio przez 4 daje to roczny dochód członków rodziny na 2500 dol., jeśli na 2-5000 dol. Jeśli podzielimy te wielkości na 12 miesięcy wychodzi odpowiednio ok. 210 i 420 dol., co nawet w chińskich dużych miastach jest bardzo skromnym dochodem. Oczywiście korzystniejsza jest sytuacja osiągających zarobków nawet do 30 tys. dol. rocznie, ale i tak nie są one powalające. Owszem pozwalają one lepiej żyć rodzinom, ale jeśli się je porówna z cenami czynszów mieszkaniowych lub $1 \mathrm{~m}^{2}$ mieszkania, są to skromne dochody.

Bez wątpienia chińska klasa robotnicza a w szczególności jej wyżej kwalifikowane warstwy zarabiają coraz więcej i jest to następstwem dynamicznego rozwoju Chińskiej Republiki Ludowej i osiągniętego znacznie wyższego poziomu gospodarczego, także socjalnego. Wydaje się także, że pewnej mitologizacji ulega kategoria i kwestia nowej „klasy średniej", przejmowana z socjologii i praktyki amerykańskiej. Powstała ona, żeby zanegować sprzeczność klasową między proletariatem a burżuazją oraz budować złudzenie (miraż) wyżej zarobkującym robotnikom, że są oni czymś „lepszym” niż nędzarski „prolet”. Historia ruchu robotniczego uczy, że jest to bardzo skuteczny środek rozbijania jedności klasowej robotników, wykorzystywany przez ośrodki burżuazyjne w schyłkowym okresie Polski Ludowej i budowania nowej 
„demokratycznej” Rzeczypospolitej po 1989 r. Szczególnie chętnie poddawała się tej argumentacji warstwa chłopo-robotników, która z trudem rozstawała się z bagażem wartości i zachowań drobnomieszczańskich i w okresie solidarnościowej kontrrewolucji wykorzystana została jako taran do walki z Polską Ludową i socjalizmem. Kierownictwo KPCh powinno wyciągnąć wnioski z tej polskiej lekcji historii.

Państwo ma charakter klasowy, a ustanawiane przez nie prawo jest wyrazem woli klasy władającej środkami produkcji. Ta podstawowa zasada marksistowska legła u podstaw powstałej w 1949 r. Chińskiej Republiki Ludowej i jest ona kontynuowana w obecnym systemie prawnokonstytucyjnym ChRL. Art. 123 Konstytucji z 1982 r. stanowi, że „sądy ludowe są organami państwowego wymiaru sprawiedliwości". Sądy ludowe funkcjonują na najważniejszych szczeblach struktury organizacyjnej państwa i zasadniczo dzieli się je na: sądy ludowe (powszechne), sądy ludowe specjalne i wyższe sądy ludowe. Najwyższą prawną instancją jest Najwyższy Sąd Ludowy w Pekinie, który orzeka w sprawach najwyższej wagi prawnej i nadzoruje orzecznictwo niższych sądów. Lokalne organy sądowe są zorganizowane odpowiednio do podziału administracyjnego państwa a sądy specjalne według właściwości prawnej. Wszyscy sędziowie są wybierani przez lokalne zgromadzenia (kongresy) ludowe i ich kadencja odpowiada kadencji tych organów. Sędziowie muszą legitymować się wykształceniem prawniczym, nienaganną opinią i cieszyć się zaufaniem organów przedstawicielskich. Sędziowie i wymiar sprawiedliwości od wieków cieszą się w Chinach wielkim poważaniem społecznym i prestiżem zawodowym.

Reformy w sądownictwie przebiegają głównie w płaszczyźnie dostosowania ustawodawstwa i postępowania do 
norm międzynarodowych i światowych standardów. Oznacza to m.in. odchodzenie od tradycyjnych norm prawnych, np. na gruncie prawa karnego publicznego karania skazanych, wykonywania kary śmierci, ograniczania i faktycznej likwidacji kary śmierci, a także stosowania tortur, odbywania kar przez skazanych w bardziej humanitarnych warunkach, co jest krytycznie przyjmowane przez niektóre środowiska tradycjonalistów jako „uleganie burżuazyjnym instytucjom prawnym". Zdaniem J. Gepperta ${ }^{25}$ szczególnie dużo nowoczesnych rozwiązań prawnych Chińczycy przyjmują z systemu niemieckiego, np. w prawie cywilnym, patentowym, praw autorskich, danych osobowych, także prawie pracy.

Art. 19 Konstytucji ChRL stwierdza, że „państwo bierze na siebie rozwój poziomu naukowego i kulturalnego całego narodu. Państwo zakłada i kieruje szkołami różnych typów, upowszechnia obowiązkową oświatę na szczeblu podstawowym i rozwija ją na szczeblu średnim, zawodowym i wyższym, podobnie jak edukację przedszkolną". Art. 23 stanowi, że „państwo przygotowuje personel specjalistyczny służący socjalizmowi, zwiększa liczbę intelektualistów i tworzy warunki dla uzyskania przez nich pełnych możliwości działania w socjalistycznej modernizacji”. Oświata jest bezpłatna na poziomie podstawowym i gimnazjalnym, na wyższych szczeblach obowiązują niewysokie stawki czesnego, rozwinięty jest system ulg i stypendialny. Realizowana od ponad czterdziestu lat "socjalistyczna gospodarka rynkowa” w mniejszym stopniu dotknęła sektor oświaty i nauki. KPCh dba o to, by obie te dziedziny znajdowały się w rękach oddanych socjalizmowi o chińskiej specyfice. Nie oznacza to, że

25 Ibidem, s. 74. 
nie podejmuje się prób prywatyzowania, ale nie tyle masowej oświaty, co szkolnictwa na poziomie wyższym. Spotkać można w miastach prywatne przedszkola, ale są one rzadkimi wyjątkami. Ministerstwo oświaty dba o podręczniki $\mathrm{i}$ inne pomoce naukowo-dydaktyczne, by odpowiadały one nie tylko światowym standardom, także jeśli chodzi o treści ideowo-polityczne. W szkołach wszystkich typów poświęca się wiele uwagi wychowaniu obywatelskiemu, patriotycznemu, aktywną działalność rozwijają organizacje pionierskie i komsomolskie. Na uniwersytetach i szkołach wyższych wykłada się tzw. przedmioty ideologiczne, a studenci obu płci objęci są szkoleniem wojskowym. Wysoki jest udział nauczycieli i profesorów w szkolnych i uczelnianych organizacjach partyjnych KPCh, które dbają o to, by najlepsi i zaangażowani politycznie oraz społecznie uczniowie i studenci ubiegali się o członkostwo w Komunistycznej Partii Chin.

Jednocześnie nie można zapominać o wartościach, zasadach i tradycjach konfucjańskich, które od ponad 2 tys. lat spajają filozoficznie, kulturowo i częściowo religijnie chińskie społeczeństwo. KPCh w okresie Mao Zedonga starało się maksymalnie oderwać od tej ideowo-kulturalnej spuścizny konfucjanizmu, upatrując w niej przysłowiową kulę u nogi. Nierzadko łączyło się to z niszczeniem ksiąg konfucjańskich i ostrymi prześladowaniami wyznawców konfucjanizmu. Od czasów Deng Xiaopinga KPCh odstąpiła od tej polityki, złagodzono kurs, a nawet znaleziono cechy wspólne ideologii socjalistycznej i konfucjańskiej, np. sprawiedliwość społeczna, harmonijne społeczeństwo, prawidłowe relacje między ludem a państwem rządzonym przez KPCh.

Współczesny system oświaty w ChRL ma pewne korzenie w ideałach wychowania i oświaty, czerpiących z warto- 
ści, zasad i ideologii marksistowskiej, socjalizmu o chińskiej specyfice, w tym z konfucjanizmu, ale jednocześnie jest on standaryzowany według Międzynarodowego Standardu Klasyfikacji Edukacji UNESCO. Jego wdrażanie i realizacja jest w rękach prowincji i regionów autonomicznych i specjalnych, a w skali centralnej koordynowany jest przez Ministerstwo Oświaty w Pekinie. Reformy znalazły inny wymiar w oświacie niż w gospodarce. Uległa ona modnej deregulacji i decentralizacji a ciężar decyzji przesunięty został na niższe piętra systemu, co znalazło wyraz w autonomizacji kwestii finansowych, kadrowych i programowych.

Oświata i nauka uczyniła w następstwie reform wielkie postępy. W 2001 r. praktycznie zlikwidowano analfabetyzm, alfabetyzacja obejmowała 98\% ludności (z reguły starego pokolenia). Jest to cywilizacyjny postęp, jeśli przypomnimy, że w czasach przedrewolucyjnych 90\% ludności, głównie na wsi, było analfabetami. Szczególnie dramatyczna była sytuacja wśród mniejszości etnicznych. Od lat 50 . XX w. wszyscy Chińczycy uczą się tzw. języka mandaryńskiego w oparciu o dialekt pekiński. Od 2009 r. ChRL znajduje się w światowej czołówce oświaty. System szkolny obejmuje szkoły podstawowe pierwszego i drugiego stopnia, szkoły zawodowe i średnie, który trwa 9 lub 12 lat, a także uniwersytety i inne szkoły wyższe. Wcześniej funkcjonują przedszkola. Po gimnazjum można iść do szkoły zawodowej lub średniej z maturą, po której można ubiegać się o studia wyższe. Czas nauki w szkole podstawowej junioralnej trwa sześć lat; uczy się w niej języka chińskiego, matematyki, przyrody, geografii, muzyki, sztuki, także innych przedmiotów, w tym od trzeciej klasy języka angielskiego. W szkołach podstawowych drugiego stopnia (secundar education) następuje dalsza specjalizacja przedmiotowa, a także można 
przygotowywać się do szkół zawodowych lub szkół ogólnokształcących z maturą lub techników. Coraz więcej młodzieży studiuje na uniwersytetach i w szkołach wyższych, jednak najwięcej w koledżach, czyli najczęściej w dwuletnich szkołach wyższych (w Polsce tzw. profesjonalne szkoły pomaturalne). Ocenia się, że do szkół wyższych trafia na pierwszy rok ok. 7 mln studentów, co stanowi ok. 50-60\% ogółu uprawnionych. Kształceniem nauczycieli zajmują się głównie tzw. „normalne uniwersytety” (Normal University). Ministerstwo Edukacji wprowadziło ranking uniwersytetów i szkół wyższych, który stał się konkurencyjny dla uniwersytetów amerykańskich i europejskich. Wprowadzono też tzw. „Listę Szanghajską” najwybitniejszych publikacji naukowych, która jest bardziej ceniona w międzynarodowych środowiskach naukowych niż np. Lista Filadelfijska. Do najlepszych uniwersytetów chińskich należy kilka uniwersytetów w Pekinie, Fudan, Jiaotang i Xinghua w Szanghaju, Chiński Uniwersytet Ludowy, Uniwersytet Zhejiang, Chiński Uniwersytet Wiedzy i Techniki, Uniwersytet w Nanjing, Jiatong w Xi'an, Uniwersytet Sun Yatsena w Kantonie i Uniwersytet w Wuhan.

Według oficjalnych danych Ministerstwa Edukacji w 2015 r. było w ChRL 2015 państwowych uniwersytetów (szkół wyższych), 292 instytuty kształcenia dorosłych i 813 innych szkół wyższych, ale tylko 75 uniwersytetów podlegało bezpośrednio Ministerstwu Edukacji. Zasadniczo w szkołach wyższych obowiązują opłaty czesnego, łagodzone licznymi formami i funduszami pomocy stypendialnej dla studentów biednych, szczególnie ze wsi. Na cele oświaty w 2012 r. rząd ChRL wydawał 4,11\% PKB, pod tym względem sytuuje się w czołówce światowej. W 2015 r. udział ten wzrósł do 4,26\% PKB. W 2014 r. na chińskich uniwersyte- 
tach i innych szkołach wyższych studiowało 42 mln studentów, co stawiało Chiny w czołówce światowej skolaryzacji.

Jednocześnie chińska nauka szybko idzie do przodu, co znalazło odzwierciedlenie nie tylko we wspomnianej „Liście Szanghajskiej" publikacji, także wynikach nowatorskich badań i wynalazkach, elektronice - 5G, sztucznej inteligencji, badań przestrzeni kosmicznej i innych dziedzinach. Są już pierwsi laureaci nagrody Nobla w różnych dyscyplinach naukowych (jak na razie zatrudnionych głównie w amerykańskich instytutach). Największa liczba nowych patentów w 2015 r. pochodziła z ChRL (825 136), wyprzedzając USA - 571612 i Japonię - 328 436. Chińska Republika Ludowa stała się pod rządami KPCh światowym centrum nie tylko w produkcji, także badań naukowych i innowacji. W $2015 \mathrm{r}$. 712157 studentów (doktorantów) chińskich studiowało za granicą, głównie w USA, Anglii, Australii i Niemczech.

Jak wspomniano, prywatyzacja w szkolnictwie, szczególnie wyższym jest znacznie słabsza niż w gospodarce, ale od kilku lat zauważa się tendencję wzrostową. W końcu 2016 r. było w Chinach 171 tys. szkół prywatnych, o 8 tys. więcej niż w 2015 r. W szkołach prywatnych w 2016 r. uczyło się 48,25 mln uczniów, wzrost w porównaniu z 2015 r. o 2,54 $\mathrm{mln}^{26}$.

$\mathrm{Na}$ odrębną uwagę zasługuje system ubezpieczeń społecznych ChRL. Występuje on w pięciu formach: ubezpieczenie zdrowotne, rentowe, na wypadek bezrobocia, wypadków przy pracy, ubezpieczenie macierzyńskie. Ostatnie zmiany upodobniły go do zachodnich standardów. System jest zróżnicowany odpowiednio do różnych prowincji i regionów i rozwija się autonomicznie. W 2012 r. Chiny otworzyły się na rynek ubezpieczeniowy firm zagranicznych.

26 Por. ibidem, s. 77. 
Wiązało się to z rozszerzeniem możliwości ich działania, przy czym są one powiązane $\mathrm{z}$ wielkimi międzynarodowymi koncernami farmaceutycznymi, fundacjami szpitalnymi, prywatyzacją służby zdrowia, zakładaniem prywatnych szpitali przez podmioty zagraniczne. Duże sukcesy w tej ekspansji odnosi niemiecki Versicherung-Allianz, który przeznacza olbrzymie środki na prowadzenie własnej firmy siostrzanej w Chinach, zgodnie z zasadą, że „bez Chin nie ma niczego”.

Kiedy w 1949 r. powstała Chińska Ludowa przeciętna długość życia w Chinach wynosiła czterdzieści lat. Było wynikiem słabego odżywiania, trudnych warunków bytowych, braku odpowiednich warunków ochrony życia i zdrowia, niedostatków bazy szpitalnej, sukcesów, ale także słabości chińskiej tradycyjnej medycyny, braku lekarstw, masowych chorób zakaźnych oraz wysokiej śmiertelności kobiet i dzieci. Oczywiście były głębokie różnice społeczno-klasowe, środowiskowe, w szczególności na wsi w zakresie ochrony życia i zdrowia i utrzymania higieny osobistej. W 2016 r. oczekiwana długość zdrowia wynosiła średnio 76,5 roku, odpowiednio więcej u kobiet i mniej u mężczyzn. Pod tym względem Chiny osiągnęły poziom państw zindustrializowanych. Jest ona prawie taka jak obecnie w Polsce, ale dotyczy to także takich schorzeń, jak nadwaga, choroby płuc, raka, zawałów, udarów, palenia tytoniu, niezdrowego odżywiania itd. Do Chin napłynęły także "małpowane" z Zachodu niezdrowe sposoby życia, przedawkowanie telewizji i komputerów, siedzący tryb życia, brak ruchu, a nawet narkotyki i alkoholizm.

Dla utrzymania tego poziomu i dalszego postępu w ochronie zdrowia niezbędne są wielkie środki finansowe, olbrzymie inwestycje i wykształcone kadry medyczne. Wszędzie odczuwa się braki w tym zakresie, ale najbardziej na wsi i w małych 
miasteczkach, gdzie nadal chińska medycyna jest często jedynym sposobem leczenia pacjentów, w związku z tym niezbędne są ubezpieczenia państwowe, obejmujące całe społeczeństwo. W 2017 r. funkcjonowało w ChRL ok. 28 tys. szpitali, 4 tys. klinik tradycyjnej chińskiej medycyny, 37015 szpitali miejskich, 33965 ośrodków zdrowia na wsi i małych miastach i 195176 ambulatoriów. Ogółem ChRL dysponowała w tym czasie 980 tys. różnymi instytucjami medycznymi, $11 \mathrm{mln}$ personelu medycznego i $7 \mathrm{mln}$ łóżek szpitalnych.

Chiny są olbrzymim rynkiem lekarstw, medykamentów i techniki medycznej. Prawie wszystkie zachodnie koncerny farmaceutyczne i wytwórnie sprzętu medycznego są w Chinach obecne. Rośnie liczba lekarstw produkcji zachodniej, które dopuszczone zostały na rynek chiński, która w 2009 r. wynosiła 133, a w 2017 - 1297. Odpowiadało to połowie środków leczniczych, które uznane były przez chińskie kasy chorych. W 2017 r. ok. 60\% szpitali w Chinach było w rękach prywatnych. Rosną koszty leczenia i rozwierają się nożyce między bogatymi i biednymi w zakresie dostępu do lepszych szpitali, specjalistów i drożejących lekarstw. Reforma służby zdrowia ujawnia coraz mocniej pogłębiającą się dyferencjację klasową społeczeństwa chińskiego.

Generalnie władze zmierzają do postawienia chińskiej służby zdrowia na poziomie europejskim lub amerykańskim, buduje się nowoczesne kliniki, modernizuje się szpitale lokalne, wprowadza się dalsze formy ubezpieczeń. W 2020 r. szpitalnictwo miało osiągnąć w Chinach poziom zachodni, ale nie jest łatwo zlikwidować liczne dawne niedostatki, np. w zakresie kształcenia lekarzy, pielęgniarek i położnych. Braki w tym zakresie są rażące, szczególnie na wsi, na której często jedynym lekarzem jest doktor tradycyjnej chińskiej medycyny. Nie oznacza to, że kwestionuje się możliwości tej medy- 
cyny w niekonwencjonalnym leczeniu niektórych chorób. $\mathrm{Na}$ uniwersytetach medycznych wykłada się wiedzę z tego zakresu, chętnie studiują ją studenci zagraniczni, a nawet wysoko kwalifikowani lekarze ${ }^{27}$.

$\mathrm{Na}$ odrębną uwagę zasługuje korupcja w Chinach, która nie jest zjawiskiem nowym w długiej historii Chin. Nie poradziły sobie z nią cesarskie Chiny, a nawet wmontowały ją do obyczajowości politycznej skorumpowanego państwa, także rządy 1. Republiki. Zasadniczy kres korupcji postawiła Chińska Republika Ludowa w czasach rządów Mao Zedonga. Wraz z wejściem Chin na drogę „socjalistycznej gospodarki rynkowej", prywatyzacją i napływem kapitałów zagranicznych korupcja odrodziła się i stanowi obecnie ogromny nie tylko prawnokryminalny, ale także polityczny problem.

Korupcja jest głównie wyrazem odnowienia stosunków burżuazyjno-kapitalistycznych i zapalnym punktem niezadowolenia obywateli. Jest to wielki problem społeczny, bowiem korupcja osłabia wizerunek KPCh, gdyż są w niej często zamieszani nie tylko niżsi funkcjonariusze partyjni, ale nawet ci z najwyższego szczebla. Według danych Międzynarodowego Indeksu Korupcji Chiny w 2016 r. znajdowały się na 79. miejscu (na ogółem 176, obok Indii, Białorusi, Brazylii, także państw Azji Wschodniej). Największymi deliktami korupcyjnymi są w Chinach przywłaszczenie własności publicznej (ziemia, bogactwa naturalne lub państwowe zakłady pracy, defraudacja państwowych pieniędzy, a także kupowanie urzędów i głosów). Korupcji sprzyja bardzo słaby system zabezpieczeń i rozgraniczeń między sektorami gospodarczymi, a także tradycyjna tolerancja społeczna, gesty i uprzejmości na granicy korupcji - bogate prezen-

27 Ibidem, s. 79. 
ty. Rząd i kierownictwo KPCh, w szczególności Xi Jinping, zdecydowanie i ostro zwalczają korupcję, w szczególności na najwyższych szczeblach władzy. Jako przykłady możemy podać aferę Zhou Yongang, Bo Xilai, Cheng Kejie, ale nie zlikwidowało to korupcji jako zjawiska. Główną przyczyną są odrodzone stosunki burżuazyjno-kapitalistyczne ${ }^{28}$.

Społeczna socjalistyczna gospodarka rynkowa i szerokie otwarcie ChRL postawiło cały szereg problemów w zakresie polityki międzynarodowej i chińskiej dyplomacji nie tylko w sprawach politycznych, ale także w sprawach gospodarczych. Chińska Republika Ludowa coraz mocniej odznacza swoją obecność w wielkich problemach zagranicznych współczesnego świata. Podstawowymi jej zasadami są zasada przyjaznej współpracy z innymi krajami i pokojowego współistnienia na zasadzie „win-win”. Strategicznymi kierunkami chińskiej polityki zagranicznej jest zabezpieczenie rozwoju zewnętrznego, stabilnej polityki regionalnej, zabezpieczenia dróg handlowych i surowców, ja i stosunki z ważnymi partnerami, w szczególności USA, Unią Europejską, Rosją, jak i bezpośrednimi sąsiadami. Chiny od ponad dziesięciu lat wdrożyły wielką międzynarodową inicjatywę w postaci Nowych Szlaków Jedwabnych (One Belt, One Road). Jest to potężny projekt nie tylko handlowo-pomocowy umożliwiający nieskremowany eksport chińskiej produkcji, ale także zabezpieczający drogi przywozowe, głównie surowców energetycznych i importu towarów. Jest ona głównie skierowana na słabiej rozwinięte kraje Azji Południowej, Aryki i Ameryki Łacińskiej, ale także na Rosję i kraje europejskie. W ramach realizacji tego programu Chiny wydały w minionej pięciolatce 8 bln dol. i kooperują z ponad 130 państwami świata.

28 Por. ibidem, s. 89. 
Chiny w polityce zagranicznej dysponują wielkimi atutami: są jednym z pięciu mocarstw świata, mając w Radzie Bezpieczeństwa ONZ prawo weta, dysponują największą armią świata i bronią atomową, liczą około 1,4 mld ludności i mają olbrzymie terytorium $\mathrm{z}$ wielkimi bogactwami naturalnymi. Chiny cieszą się uznaniem i szacunkiem nie tylko wielkich partnerów, ale przede wszystkim państw rozwijających się, których jest nieoficjalnym przywódcą. W stosunkach z USA i Unią Europejską Chiny są postrzegane już nie jako „papierowy tygrys”, ale jako groźny konkurent, przeciwnik, a nawet strategiczny wróg gospodarczy i ideowo-polityczny, co udokumentowały ostatnio napięcia i wojna handlowa między USA i Chinami. ChRL jest także członkiem grupy G20, państw BRICS, SOE i staje się coraz mocniejszym partnerem, a nawet fundamentem nowego światowego ładu gospodarczego. Chiny otworzyły się na świat i zdobyły obecnie taką pozycję, że chcą w nich inwestować największe korporacje świata. Nie obawiają się one obcej konkurencji, natomiast burżuazyjne ośrodki coraz bardziej boją się Chin i szukają środków, by powstrzymać ich pokojową ekspansję ekonomiczną i handlową. „Chiny nikomu nie zagrażają”, powiedział ostatnio Przewodniczący Chin Xi Jinping i tym się różnią od mocarstw kapitalistycznych.

Nowe kierownictwo KPCh pod kierunkiem Xi Jinpinga dąży do pokojowego współistnienia z wszystkimi państwami, szczególnie z wielkimi mocarstwami, są wielkim mocarstwem nie tylko gospodarczym, ale dysponują także wystarczającym potencjałem obronnym, by odeprzeć ewentualną agresję potencjalnego napastnika. Aktualnie rośnie ponownie napięcie między Stanami Zjednoczonymi i Chinami, które jest kontynuacją polityki dawnego prezydenta D. Trumpa. Jest to polityka nie tylko gospodarczego, 
ale także militarnego okrążania Chin, w której aktywną rolę pełnią także inne państwa NATO, ANZUS, a także innych ugrupowań militarnych. Nie można wykluczyć w perspektywie, że te napięcia ośrodki burżuazyjno-kapitalistyczne będą chciały przekształcić w nowy konflikt wojenny. USA wykorzystują bezpośrednie naciski gospodarcze i handlowe na Chiny (embargo, sankcje i restrykcje), ale także wpływają na bliskich sąsiadów Chin, w tym KRLD, Wietnam, głównie jednak Tajwan (który zachęca się do dalszej secesji) w celu stworzenia napięcia międzynarodowego w rejonie Morza Południowochińskiego.

W praktyce zagranicznej ChRL dyskontuje zmianę sytuacji międzynarodowej, określaną jako świat wielopolarny. USA przestały się liczyć jako jedyny hegemon świata, tracą swoją dotychczasową przewagę gospodarczo-finansową, wyrosły nowe potęgi, jak Unia Europejska, a w niej głównie Niemcy. Wiele do powiedzenia w polityce międzynarodowej ma także Rosja, która nie uznaje dyktatu USA i NATO i ściśle kooperuje z Chińską Republiką Ludową, odradza się także wielki Ruch Państw Niezaangażowanych, które ściśle kooperują z Chinami.

Z tej analizy wynika, że można postawić ostrożną prognozę, że obecnie świat stał się bardziej bezpieczny i nie grozi mu jakaś nowa wielka wojna lub groźny konflikt wojenny, ale nie są wykluczone mniejsze konflikty, które można określić jako zastępcze, np. na Morzy Południowo-chińskim, w Cieśninie Malakka, na Bliskim Wschodzie. Być może imperialistyczne awanturnictwo da o sobie znać bliżej Polski, np. na Ukrainie lub na Kaukazie. 


\section{Podsumowanie}

Podsumowując można stwierdzić, że Chińska Republika Ludowa od ponad siedemdziesięciu lat jest państwem socjalistycznym $\mathrm{w}$ formie demokracji ludowej, które $\mathrm{z}$ wielkimi sukcesami przeprowadziło rewolucję antykapitalistyczną, częściowo antyfeudalną, demokratyczną i socjalistyczną. Jest to okres trzech pokoleń, co w życiu człowieka jest całą epoką, ale w historii Chin jest to stosunkowo krótki czas. Jednocześnie trzeba wskazać na jakościowe następstwa społeczno-gospodarcze i polityczne, które są rezultatem głównie socjalistycznego etapu rewolucji.

Rewolucja i socjalistyczne przemiany odbywały się w dwóch głównych etapach:

1. okres 1949-1976 pod ideowo-politycznym przywództwem Komunistycznej Partii Chin, na czele z Mao Zedongiem;

2. okres od 1977/1978 - do czasów obecnych pod kierownictwem Deng Xiaopinga i jego następców, w tym obecnego sekretarza generalnego KC KPCh i Przewodniczącego Xi Jinpinga.

Problematyka rozpatrywana jest w trzech aspektach:

1. chińska droga do socjalizmu jako przedmiot krytyki;

2. rozwój Chińskiej Republiki Ludowej przez sprzeczności;

3. podstawowe sprzeczności socjalistycznej gospodarki rynkowej w opiniach jej krytyków.

Od początku chińska rewolucja i chińska droga do socjalizmu różniła się od wcześniejszych form rewolucyjnych w Komunie Paryskiej i w Rosji, a później w Związku Radzieckim. Bardziej nawiązywała ona do doświadczeń innych 
państw socjalistycznych, określanych jako państwa demokracji ludowej. Jednocześnie Komunistyczna Partia Chin nie mogła i nie chciała odejść od wielkich historycznych zdobyczy chińskiej cywilizacji, określanych w poł. XIX w. przez K. Marksa jako „azjatycki typ produkcji”.

Szczególnie daleko idące różnice w budowie socjalizmu w Chinach nastąpiły w konsekwencji objęcia przywództwa w KPCh przez Deng Xiaopinga i jego kontynuatorów, wdrożenia nowych reform gospodarczych, częściowego ożywienia rynku i szerokiego otwarcia się Chin na kooperację z wielkim kapitałem zagranicznym, przy zachowaniu kontroli politycznej, finansowej i gospodarczej Chińskiej Republiki Ludowej. Otwarło to nowe wielkie możliwości rozwoju kraju, modernizacji gospodarki, a jednocześnie zrodziło cały szereg nowych sprzeczności, w tym klasowewych. Kwestie te podzieliły w znacznym stopniu samą Komunistyczną Partię Chin oraz międzynarodowy ruch komunistyczny, m.in. zarzuca się KPCh, że odchodzi ona od ideałów socjalistycznych i ulega kontrrewolucji.

Zdaniem autorów artykułu zarzuty te nie są w pełni uzasadnione. Zagrożenia na pewno występują, ale Komunistyczna Partia Chin kontroluje sytuację politycznie, ekonomicznie i finansowo. Na oryginalność chińskiej drogi do socjalizmu wpływa sinizacja marksizmu i włączenie do ideologii KPCh postępowych wartości i zasad konfucjanizmu, co przyczynia się do umocnienia zwartości chińskiego ludu i realizacji budowy socjalizmu o chińskiej specyfice, ale przyszłościowo ogranicza i izoluje tę koncepcję do kręgu chińskiej cywilizacji. 


\section{Bibliografia}

"Azja-Pacyfik: Społeczeństwo - Polityka - Gospodarka” 2015, t. XVIII: Chiny w kręgu nowych kultur, Toruń 2015. „Nowa Krytyka” 2017, nr 38; 2019, nr 42 i in.

„offen-siv”: Fazit, „offen-siv. Zeitschrift fuer Sozialismus und Frieden", marzec-kwiecień 2021, nr 3 (20/21).

„Revolutionary Democracy”, październik 2017, vol. XXIII, nr 1.

Blessing K., Die sozialistische Zukunft. Kein Ende der Geschichte. Eine Streitschrift, Berlin 2014.

Bożyk P., Apokalipsa wedtug Pawta. Jak zniszczono nasz kraj, Wrocław 2015.

Brar Harpal, Imperialism, Decadent, Parasitic, Moribund, Dehli 1997.

Chen Wenling, Heads or Tails? A look at where Sino-U.S. relations may be under the Biden presidency, „Beijing Review", 28.01.2021, nr 4.

Chołaj H., Powrót olbrzyma w zglobalizowanym świecie, Warszawa 2011.

Czubiński A. (red.), Polski ruch robotniczy. Zarys historii, Warszawa 1974.

Czubińskie A., Olszewski W., Historia powszechna 1939-1997. Podręcznik dla studentów historii i nauk politycznych, Poznań 1999.

Deng Xiaoping, Chińska droga do socjalizmu. Wybór prac z lat 1956-1987, Warszawa 1988.

Deutscher I., Stalin, eine politische Biographie, Berlin 1990. Fenby J., Chiny. Upadek i narodziny wielkiej potęgi, Kraków 2009.

Geppert J., Politische Analyse Chinas; „offen-siv”, „Zeitschrift fuer Sozialismus und Frieden" 2021, nr 3.

Gossweiler K., Wie konnte das geschehen? Sammlungen der 
Analysen, Referate, Kritiken, Reden und Briefe..., Beitraege 1-3. Herausgeber: KPD, „offen-siv”, Freidenker-Verband, GRM Eulenspiegel-Verlag, Bodenfelde 2017.

Granet M., Cywilizacja chińska, Warszawa 1973.

Hermsdorf V., Kontinuitet und Veraenderung - die Kommunistische Partei Kuba hielt ihren 8. Parteitag ab., „Unsere Zeit", Essen, 30.04 2021, nr 17.

Ho Chi Minh, Gefängnistagebuch. Gedichte, Berlin 2020.

Hohmann R., Zielvorgabe Krieg, „Unsere Zeit” Essen, 17.02. 2021, nr 7.

Hu Jintao, Wystapienie na XVIII Kongresie KPCh, Toruń 2013.

Hungtinton S.P., Zderzenie cywilizacji iu nowy kształt tadu światowego, Warszawa 1997.

Initiative Communiste" - Mensuel du Pole de Renaissance Communiste en France - P.R.C.F, Lievin, France.

Jarema D., Polityka Chińskiej Republiki Ludowej wobec mniejszości etnicznych, „Zeszyty Naukowe Ruchu Studenckiego" 2013, nr 2.

Jung Chang, Halliday J., Mao. Nieznana historia, Kraków 2021.

Kijas A., Morzy J., Ochmański J., Zarys dziejów ZSRR, Warszawa 1984.

Kim Il Sung, Reminiscences with the Century. Foreign languages Publishing House, Phenian 1995.

Kim Ir Sen, Memuary, w woboworotie wieka. Izdatielstwo litieratury na innostrannych jazykach, t. 1-3, Phenian 1992.

Kim Ir Sen, Pamiętniki w wirze stulecia, t. 1, Cieszyn 1996. Koberdowa J. (red.), Międzynarodowy ruch robotniczy, t. 1-2, Warszawa 1976.

Kochan J., Socjalizm, Warszawa 2013. 
Kołodko G., Czy Chiny zbawiq świat, Warszawa 2018.

Kołodko G., Dokąd zmierza świat, Ekonomia polityczna przyszłości, Warszawa 2013.

Koppe R., Sozialismus nur ohne Mark? Ueber Kubanischen Weg zum Sozialismus, „Unsere Zeit”, 30.04.2021, nr 17.

Kryszewski W. (oprac.), Polska. Informator encyklopedyczny, Warszawa 1986.

Kubi M., Die Sowjetdemokratie und Stalin. Theorie und Praxis in der Sowjetunion 1917-1953. Herausgeber „offen-siv", Hannover 2015.

Kurasow W.W., Historia powszechna, oprac. Akademia Nauk ZSRR, w szczególności t. 10, Warszawa 1975.

Liu Haitao, Grand Design, China forges ahead in promoting world peace and common development, „Beijing Review”, 2.11.2017, nr 44.

Mao Tse-Tung, Dzieła Wybrane, t. 1-4, Warszawa 1953.

Marszałek-Kawa J. (red.), Aspects of contemporary Asia. Security and economy, Torun 2015.

Marszałek-Kawa J. (red.), Chiny i świat zewnętrzny, Toruń 2016.

Marszałek-Kawa J. (red.), Economic and energy stability in Asia. Perspectives and scenarios, Toruń 2016.

Marszałek-Kawa J. (red.), Is the $21^{\text {st }}$ Century the Age of Asia?, Toruń 2012.

Marszałek-Kawa J., Helnarska K.J., Polityka państw azjatyckich. Wyzwania i dylematy, Toruń 2015.

Marszałek-Kawa J., Stelmach A., Walkowski M. (red.), Nowa pozycja Chin w zmieniajacym sięświecie. Polityka-ekonomia-spoteczeństwo, Toruń 2017.

Muszyński J. (red.), Teoria Naukowego Komunizmu, Warszawa 1976.

Obama B., Ziemia obiecana, Warszawa 2021. 
Orzechowski M., Rewolucja, socjalizm, tradycje: przeszłość narodowa i tradycje $w$ myśl politycznej rewolucyjnego nurtu polskiego ruchu robotniczego, Warszawa 1978.

Pan Chwan Czżu, Korea - Kratkoje swiedienije, Phenian 1988.

Piechówka S., Transformacja polityczna Chińskiej Republiki Ludowej ma poczatku XXI wieku, praca doktorska obroniona w Instytucie Politologii Uniwersytetu Wrocławskiego w 2016 r..

Priestland D., Welt-Geschichte des Kommunismus. Verlagsgruppe Random House, Berlin 2009.

Rakowski M., Przemiany i szanse socjalizmu (w konfrontacji z kapitalizmem od czasów Marksa po bliska przyszłość), Warszawa 2004.

Rodziński W., Historia Chin, Wrocław 1974.

Samir Amin, Zmurszaty kapitalizm, Warszawa 2004.

Schnehen G., Stalin, Eine Marxistische Biographie, Bochum 2019.

Schneider H., Ueber die Russen und ueber uns, „Rot Fuchs” Tribuene fuer Kommunisten und Sozialisten in Deutschland" 2017, nr 11.

Secomski K. et. al (red.), 35 lat gospodarki Polski Ludowej, Warszawa 1979.

Song Hongbing, Wojna o pieniadz 2. Świat wtadzy pienia$d z a$, Bielany Wrocławskie 2009.

Starcie tytanów. BRICS vs. USA, „Opcja na prawo” 2015, nr 2/ 139.

Stiglitz J., Globalizacja, Warszawa 2007.

Study on the Sinicization History of Marxism. Makeshi

Zhuyi Zhongguochua Shi, Wuhan 2015.

Szymczak T., Ustrój polityczny Związku Socjalistycznych Republik Radzieckich (1936-1976), Wrocław 1978. 
The Transformation of Central Asia under Soviet power, „Lalkar”, Monthly of the CPGB-ML, Birmingham, listopad-grudzień 2017, nr 245.

Wajda A., Globalizacja. Społeczeństwo i jego rozwój, Warszawa 2011.

Wang Hairong, Embarking on a New Journey. CPC National (XIX) Congress opens a new chapter for the Chinese nation, „Beijing Review”, 2.11.2017, nr 44.

Wang Yiwei, Understanding the CPC, „Beijing Review”, 15 April, nr 17.

Wardęga J., Chiński nacjonalizm. Rekonstruowanie narodu w Chińskiej Republice Ludowej, Kraków 2014.

Wiejacki W., Sprzeczności społeczno-polityczne wspótczesnych Chin, praca doktorska obroniona w Instytucie Politologii Uniwersytetu Wrocławskiego w 2016 r.

Wiktor Z., Chiny na drodze socjalistycznej modernizacji, Toruń 2008.

Wiktor Z., Chińska wizja budowy socjalizmu w świetle materiatów XIX Zjazdu KPCh, [w:] Wektory zmian w polityce Chińskiej Republiki Ludowej w okresie rzadów Xi Jinpinga, red. J. Marszałek-Kawa, Torun 2019.

Wiktor Z., Dr (Jia) Wei Xiao, Thoughts on Theoretical Problems in the Book of President Xi Jinping Zarzadzanie Chinami, t. I (The Governance of China, vol. I), Torun 2019, "Reality of Politics. Estimates - Comments - Forecasts", 2019/2020, nr 10.

Wiktor Z., Marksizm a konfucjanizm w ideologii Кomunistycznej Partii Chin, [w:] Ideologia i przywództwo we wspótczesnych Chinach, red. D. Kawa, Toruń 2019.

Wiktor Z., Przyczynek do analizy sprzeczności wspótczesnych Chin, „Studia Orientalne” 2016, nr 2 (10). 
Wiktor Z., Rakowski M., Rozwój i prognozy przyszłości Chin $w$ zmieniajacym się świecie, Torun 2012.

Wiktor Z., Skład socjalno-klasowy KPCh w świetle 18. Kongresu, „Studia Orientalne” 2014, nr 2 (6).

Wiktor Z., Związki między polityka, ekonomia a nauka $w$ Chinach. Sprawozdanie z Międzynarodowej Konferencji Naukowej na temat marksizmu i socjalizmu w XXI wieku. Wuhan 21-22 listopada 2015 r., „Studia Orientalne" 2016, nr 9.

Woerterbuch der Geschichte, t. 1-2, Berlin 1983.

Wolton T., Historia komunizmu na świecie. Próba dochodzenia historycznego, Kraków, 2021

Xi Jinping, Innowacyjne Chiny, Warszawa 2015.

$\mathrm{Xi}$ Jinping, Report to the $19^{\text {th }}$ CPC National Congress. Highlights of Xi Jinping's Report. Into a New Era. Marching toward. A decesive victory, „Beijing Review” 2017, nr 43.

Xi Jinping, The Governance of China, Beijing 2014.

Xi Jinping, Zarzadzanie Chinami, Toruń 2019.

Zhang Zhuoyuan (red.), Translated by Pan Sai, Li Pengfei,

China's Economic Tendencies under the New Normal, Beijing 2017.

Zhao Yongsheng, Financial Reforms in China. From an Institutional, Beijing 2017.

Zheng Hangsheng, Li Yingsheng, Historia chińskiej socjologii, bez daty wydania, prawdopodobnie 2008.

Zieliński E., Wietnam socjalistyczny - zjednoczony, Warszawa 1978.

Zubok Ł.I. et al. (red.), Historia Drugiej Międzynarodówki, t. 1-2, tlum. J. Bukowski, Warszawa 1978. 


\begin{abstract}
Abstrakt
Socjalistyczna gospodarka rynkowa lub szerzej chińska droga do socjalizmu jest przedmiotem głębokiej kontrowersji ideowej, politycznej i gospodarczej nie tylko w samych Chinach, szczególnie w gremiach kierowniczych KPCh, także w międzynarodowym ruchu robotniczym i komunistycznym. Z jednej strony jest ona postrzegana jako nowatorskie rozwinięcie marksizmu, które ma zastosowanie w państwie o słabym rozwoju gospodarczym, w tym w szczególności przemysłu oraz z licznymi pozostałościami struktur i stosunków przedkapitalistycznych formacji społecznych. Z drugiej strony formułowane są krytyczne opinie i oceny, zarzucające Deng Xiaopingowi, jego reformom i kontynuatorom odejście od podstawowych zasad i wartości marksizmu i naukowego socjalizmu oraz przejście na stronę kontrrewolucji, zdradę sprawy socjalizmu i pokojową restaurację kapitalizmu. Kwestia ta jest żywo dyskutowana nie tylko w Chinach, także w poszczególnych partiach komunistycznych i na różnych konferencjach międzynarodowego ruchu komunistycznego i dzieli ten ruch na stronnictwo pro- i antychińskie w rozumieniu partyjno-ideologicznym i politycznym.
\end{abstract}

Słowa kluczowe: socjalizm, komunizm, Komunistyczna Partia Chin, Chińska Republika Ludowa, chińska droga do socjalizmu, socjalistyczna gospodarka rynkowa, socjalizm o chińskiej specyfice, wstępne stadium socjalizmu, okres przejściowy od kapitalizmu do socjalizmu, umiarkowanie rozwinięte społeczeństwo we wszystkich aspektach, narodowe odrodzenie, sprzeczności klasowe w Chinach, likwidacja ekstremalnej nędzy, rola nowej narodowej burżuazji, nowych miliarderów i milionerów, „klasa średnia” w Chinach, rola obcego i własnego kapitału, nowe formy wyzysku, Rola konfucjanizmu, naukowy socjalizm, rewizjonizm, reformizm, oportunizm, silne i słabe strony socjalistycznej gospodarki rynkowej, chińska gospodarka jako ekonomia hybrydowa, kapitalizm w bazie, socjalizm w nadbudowie, sukcesy i zagrożenia socjalistycznej gospodarki rynkowej, sprzeczności międzynarodowe i zagrożenia ze strony imperializmu, perspektywy rozwoju KPCh, Chińskiej Republiki Ludowej i świata

\title{
Abstract
}

The socialist market economy, or the so-called Chinese way to so- 
cialism, is a subject of vast ideological, political, and economic controversy not only in China, particularly in the highest circles of the $\mathrm{CPC}$, but also in international labor and Communist movement. On the one hand, it is perceived as an innovative extension of Marxism, that can be implemented in a weakly developed state in terms of economy, especially industry, and with numerous pre-capitalist social formations' left-overs and relations. On the other hand, critical opinions and assessments are formed toward it, that blame Deng Xiaoping, his reforms, and followers for departing from the fundamental principles and values of Marxism and scientific socialism, and changing side to counter revolutionist, betraying the socialist cause, and peaceful reviving capitalism. The matter is lively discussed in China and various Communist parties at the conferences of international Communist movement and splits it into pro- and anti-Chinese camps in terms of party-ideology and politics.

Keywords: ideological-political controversies on the Chinese way to socialism, socialism, communism, communist party of China, China people's republic, Chinese path to socialism, socialist market economy, socialism with Chinese characteristics, initial stage of socialism, transition period from capitalism to socialism, moderately prosperous society in all respects, national rejuvenation, class contradictions in China, the liquidation of the extremal poverty, the role of the new national bourgeoisie, new billionaires and millionaires, the "middle class" in China, the role of the foreign and owner capital, new forms of the exploitation, the role of the Confucianism, scientific socialism, revisionism, reformism, opportunism, the strong and weak sides of the socialist market economy, Chinese economy as the hybrid economy, capitalism in base and socialism in superstructure, the success and threats of socialist market economy, the international contradictions and the threat of imperialism, the perspective of the $\mathrm{CPC}$, of the China people's republic and of the world 


\section{Leszek Krzysztof Sadurski}

Uniwersytet Marii Curie-Skłodlowskiej w Lublinie

ORCID ID: https://orcid.org/0000-0002-8900-5451

\section{Wpływ duńsko-grenlandzkiego konfliktu o samorządność Grenlandii na współczesne bezpieczeństwo w euroatlantyckiej części Arktyki}

\section{Wstęp}

Grenlandia jest największą wyspą świata, zamieszkiwaną przez 57 tys. Grenlandczyków. Od XVIII w. kolonizowana przez Duńczyków stanowiła integralną część Królestwa Danii do 1953 r. ${ }^{1}$ Od XX w. jako część Arktyki cieszy się zainteresowaniem naukowców - głównie geologów, hydrologów i glacjologów. Jednak po obserwacjach poczynionych przez klimatologów, według których opublikowano prognozy traktujące o tym, że w związku z globalnymi zmianami klimatu obszar znajdującego się tam lądolodu będzie się kurczył, wyspa ta poczęła zyskiwać coraz większą uwagę w dyskursie medialnym, politycznym i wojskowym ${ }^{2}$. Zmiany klimatyczne umożliwiły wykorzystywanie zasobów naturalnych znajdujących się dotąd w niedostępnych miejscach. Należy

1 CIA Factbook, https://www.cia.gov/library/publications/the-world-factbook/geos/gl.html [dostęp: 25.11.2019].

2 J. Symonides, Arktyka - region wspótpracy czy konfliktów, „Stosunki międzynarodowe" 2011, nr 3-4 (44), s. 9. 
tu wymienić rudy takich metali, jak żelazo i cynk oraz tzw. metali rzadkich ${ }^{3}$. W związku z tym wśród Grenlandczyków zaczęły się pojawiać głosy o chęci uczestnictwa w rozmowach nt. przyszłości wyspy i możliwości jej rozwoju. Stopniowa emancypacja przerodziła się w pomysł uzyskania większej niezależności, samorządności czy wręcz niepodległości od Kopenhagi. Taki obrót sprawy nie jest jednak mile widziany wśród Duńczyków, którzy chcą realizować własne interesy niebędące całkowicie tożsame z punktem widzenia Grenlandczyków. Sytuacja ta zrodziła konflikt. Jest to ważny temat, ponieważ pokazuje, że w dzisiejszych czasach są narody, które nie posiadają własnego państwa. Posiadając autonomię nie czują się w pełni gospodarzami na własnym terytorium. Sytuacja ta obrazuje, że nawet w państwie bogatym jak Dania, gdzie system socjalny jest rozwinięty, mogą istnieć społeczeństwa nie do końca usatysfakcjonowane życiem w nim. Poza tym ciekawe jest zagadnienie w jaki sposób cywilizowane państwa próbują rozwiązywać takie konflikty i jak tego typu spór może wpływać na międzynarodowe bezpieczeństwo w ujęciu regionalnym.

Etymologicznie słowo konflikt (łac. conflictus) oznacza zderzenie, sprzeczność poglądów, interesów, spór, zatarg, niezgodność, kolizję. Jest on cechą relacji społecznych - zaczynając od stosunków międzyludzkich, a kończąc na podmiotach międzynarodowych. Jest to stan społeczny, który pojawia się w chwili, kiedy co najmniej dwa podmioty dzia-

3 Chodzi o 17 pierwiastków, m.in. neodym, samar, gadolin, erb. lantan, cer, promet, europ, które są obecnie wykorzystywane w przemyśle elektronicznym, lotniczym, wojskowym czy kosmicznym. Z nich produkuje się takie rzeczy i urządzenia, jak turbiny wiatrowe, lasery, ekrany krystaliczne czy urządzenia medyczne stosowane do diagnostyki za pomocą rezonansu magnetycznego. Ponadto na wyspie znajdują się złoża węgla, niobu, ołowiu, tantalu, niklu, srebra, molibdenu, uranu oraz diamenty. 
łają w kierunku zrealizowania wzajemnie wykluczających się, przeciwstawnych lub niekompatybilnych celów. Wynika to z różnicy interesów, czyli wyrażenie przez dany podmiot zainteresowania jakąś rzeczą, celem abstrakcyjnym bądź materialnym i podejmowanie działania, aby go osiągnąć $c^{4}$.

W celu omówienia tematu postawiono pytania problemowe o następującej treści:

- czym przejawia się spór grenlandzko-duński o samorządność Grenlandii?

- jak idea samostanowienia Grenlandczyków wpływa na relacje grenlandzko-duńskie w kwestii samorządności Grenlandii?

- w jaki sposób konflikt ten może wpłynąć na współczesne bezpieczeństwo w euroatlantyckiej części Arktyki?

Aby odpowiedzieć na te pytania wykorzystano w artykule metodę badawczą porównawczą. Przy zastosowaniu tej metody jednym parametrem było stanowisko duńskie, które porównywano do drugiego parametru - stanowiska grenlandzkiego. Wykorzystano metody historyczne poprzez ujęcie tematu i przedstawienie problemu w ramach czasowych obejmujących okres od 2009 do 2018 r. Zastosowano także metodę prognostyczną w przypadku tworzonych scenariuszy możliwości rozwoju sytuacji w regionie.

\section{Spór grenlandzko-duński o status Grenlandii}

Arktyka pod względem politycznym charakteryzuje się specyficznym regionalizmem, który oprócz udziału państw obejmuje również udział rdzennych mieszkańców jacy za-

4 W. Szymborski, Międzynarodowe stosunki polityczne, Bydgoszcz 2012, s. 124. 
mieszkują owe terytoria a zrzeszonych w organizacjach. Dzięki temu arktyczni autochtonowie stali się aktorami regionalnymi i międzynarodowymi partycypującymi w kształtowaniu się porządku arktycznego oraz jednocześnie kreujący swoją pozycję polityczną, stawiając czoło wyzwaniom pojawiającym się w przyszłości ${ }^{5}$.

Zwiększenie się roli ludów rdzennych na poziomie narodowym pozwoliło na polityzację i profesjonalizację działań organizacji, które tworzą. Rozwinęły w nich poczucie samostanowienia, co prowadzi do chęci wprowadzenia zmian związanych z nowym podziałem władzy wyrażającym się m.in. we współdecydowaniu o gospodarce przestrzennej i eksploatacji zasobów naturalnych.

W kontekście Grenlandii należy wspomnieć o Okołopolarnej Radzie Inuitów, która nabywszy charakteru politycznego i zwiększeniu swych zdolności instytucjonalnych przyczynia się do uwzględniania głosu Grenlandczyków na forum międzynarodowym, podnoszeniu ich samoświadomości oraz pozwala na profesjonalne i skuteczne negocjowanie swych interesów z rządem duńskim. Wynikiem dążeń Inuitów do zapewnienia potrzeb związanych z istnieniem własnego samorządu oraz możliwości decydowania o własnym losie i kontrolowania zasobów naturalnych znajdujących się na wyspie było uzyskanie statusu autonomii w 1979 r. ${ }^{6}$ Zaś w 2009 r. w wyniku referendum przeniesiono na Grenlandczyków dodatkowe kompetencje, związane

5 A. Stępień, Rola ludów rdzennych w budowaniu Arktyki jako regionu politycznego, [w:] Arktyka na poczatku XXI wieku. Między rywalizacja a wspótpraca, red. M. Łuszczuk, Lublin 2013, s. 373.

6 W referendum z 17 stycznia 1979 r. mieszkańcy Grenlandii opowiedzieli się za wprowadzeniem autonomii w ramach Królestwa Danii. Od 1 maja 1979 r. Grenlandia formalnie stała się autonomią o statusie terytorium zamorskiego, zyskując samorząd. 
z zarządzaniem wewnętrznym na wyspie, pozostawiając Kopenhadze jedynie możliwość decydowania w kwestiach obronności, prowadzenia polityki zagranicznej oraz polityki monetarnej ${ }^{7}$.

Wydawałoby się, że kwestia niepodległości jest przesądzona, ale dotychczas utrzymujące się na bardzo wysokim poziomie dotowanie funkcjonowania Grenlandii z duńskiego budżetu w wysokości $500 \mathrm{mln}$ euro rocznie, spowodowane brakiem pozyskiwania zakładanych dochodów z eksploatacji surowców, nie pozwala na pełne uniezależnienie się wyspy ${ }^{8}$. Sytuacja ta rodzi napięcia i konflikty w polityce, ponieważ Grenlandczyków frustruje niemożność w pełni samodzielnego zarządzania swoimi sprawami, potrzebując często zgody Duńczyków.

Możliwość uzyskania niepodległości przez Grenlandię w bezwzględny sposób skomentował duński polityk i były minister ds. energii Svend Auken, mówiąc: „Na dłuższą metę idealnym rozwiązaniem byłoby dla nich [Grenlandczyków przyp. L.K.S.] uznanie wyspy przez ONZ jako niezależnego państwa, ale w bliskich związkach z Danią. Inaczej staną się zależni od Amerykanów, a wiedzą, że to oznacza koniec spo-

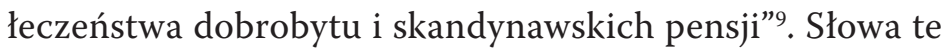
oddają specyficzny, kolonialny charakter wyższości Duńczyków nad Grenlandczykami, który utrzymywał się na Grenlandii przez dziesiątki lat. Potwierdzają to słowa grenlandz-

7 A. Stępień, op.cit., s. 376.

8 Ch. Opitz, T. Etzold, Grenlandia: dążenie do niezależności bez uwzglednienia podstaw ekonomicznych, https://www.euractiv.pl/section/ polityka-wewnetrzna/opinion/grenlandia-dazenie-do-niezaleznosci-bez-uwzglednienia-podstaw-ekonomicznych/ [dostęp: 4.12.2019].

9 J. Irząbek, Wyspa chce niepodlegtości, „Polityka”, https://www.polityka.pl/tygodnikpolityka/swiat/250999,1,wyspa-chce-niepodleglosci. read?page $=106 \&$ moduleId=4781 [dostęp: 4.12.2019]. 
kiego lingwisty Nuuki Mollera, który powiedział: „Podczas niedawnej debaty na temat niepodległości czułem się, jakbym cofnął się o 30 lat" ${ }^{\prime 10}$. Natomiast całą tę sytuację skomentował Duńczyk, będący dziekanem Wydziału Historii i Kultury na Uniwersytecie Grenlandii, iż „Mieszkańcy Grenlandii zawsze byli traktowani tak jak pozostali duńscy obywatele, a ich język był dla królestwa jednym z powodów do dumy, świadczył bowiem o rozległości duńskiego imperium" i dalej, w nawiązaniu do wyniku referendum z 17 stycznia 2009 r. jakoby był emocjonalną reakcją Grenlandczyków: „Nie chcą [Grenlandczycy - przyp. L.K.S.] już dłużej być tym, kim byli do tej pory: królewskimi poddanymi z Północy, dotowanymi przez Kopenhagę"11. Ton wyższości wypływający z tych słów jest jedną z przyczyn wywołujących frustrację Grenlandczyków, która objawia się konfliktem z Duńczykami.

Rezultatem tychże stały się działania zmierzające do poszerzenia swej samorządności. Ponadto widoczna różnica poglądów na ten temat stanowi obraz niezrozumienia pomiędzy Duńczykami a Grenlandczykami. To osobne etnosy, których nie można traktować jako jedność. Sytuację tą, będącą charakterystyką funkcjonowania Grenlandczyków przed referendum opisuje studentka Lena Broberg: „Jeśli chcemy zdobyć wykształcenie, musimy mówić po duńsku. To bardzo smutne. Duńczycy i Grenlandczycy rozumują w inny sposób, dlatego tak trudno nam jest zrozumieć się nawzajem (...)" ${ }^{\prime 2}$. Nic więc dziwnego, że Grenlandczycy postanowili wziąć sprawy we własne ręce i rozpoczęli debatę

10 P. Barkham, Niepodległość na Grenlandii?, https://www.polityka. pl/tygodnikpolityka/swiat/279999,1, niepodleglosc-dla-grenlandii.read [dostęp: 5.12.2019].

11 Ibidem.

12 Ibidem. 
nad poszerzeniem swych uprawnień w stosunku do Metropolii, której wnioski wychodziły nawet dalej niż początkowo zakładano - stała się początkiem dyskusji nad całkowitym oderwaniem się od Królestwa Danii, co już było szeroko i nerwowo komentowane w Kopenhadze. Należy bowiem zauważyć, że Duńczycy chcą utrzymać Grenlandię przy sobie, ponieważ sami czerpią z tego tytułu korzyści. Jeśli byłaby balastem, to na pewno by nie stawiali oporów.

\section{Przykładowe sytuacje konfliktowe na linii Nuuk-Kopenhaga po referendum z 2009 r.}

Choć do tej pory Grenlandia nie uzyskała niepodległości, to poszerzenie zakresu autonomii w 2009 r. skutkowało uznaniem Grenlandczyków za naród, który posiada prawo do samostanowienia. Język grenlandzki uznano jako urzędowy. Istotne stało się również postanowienie dotyczące uzyskania przez rząd grenlandzki kontroli nad zasobami występującymi na wyspie. Dzięki temu Grenlandczycy uzyskali prawo do decydowania komu i za ile będą udostępniać ewentualne złoża, do tej pory zarządzane przez Duńczyków. Jednocześnie podział zysków z tego tytułu wygląda następująco: pierwsze $75 \mathrm{mln}$ koron duńskich pochodzących z wydobycia surowców ma trafić do budżetu grenlandzkiego. Ewentualna nadwyżka będzie dzielona na połowę, przy czym owe dodatkowe profity będą zmniejszały wysokość corocznie wypłacanych duńskich subsydiów ${ }^{13}$. Zważywszy na fakt, iż poziom zysków może wzrosnąć, to podział w takiej formie

13 T. Brańka, Znaczenie Grenlandii w polityce Danii oraz we wspótczesnych stosunkach międzynarodowych, [w:] Arktyka na poczatku XXI wieku. Między rywalizacją a wspótpraca, red. M. Łuszczuk, Lublin 2013, s. 482-483. 
może w dłuższej perspektywie być niezadowalającym dla Grenlandczyków.

W tym kontekście między Grenlandczykami a Duńczykami rozgorzał konflikt w 2013 r. dotyczący wydobycia i sprzedaży uranu, którego duże zasoby znajdują się na terytorium wyspy. W ten sposób władze Grenlandii chciały zyskać dodatkowe fundusze na funkcjonowanie i rozwój autonomicznej części Królestwa Danii i zamieszkującego ją społeczeństwa. Tłumaczą to słowa premier Grenlandii Aleqi Hammond: „Nie możemy żyć ze stale wzrastającym bezrobociem i coraz wyższymi kosztami utrzymania ponieważ nasza gospodarka jest w stanie zastoju. Musimy skończyć z polityką »zero tolerancji dla uranu«"14.

Jedną z pierwszych firm, która otrzymała koncesję była brytyjska London Mining. Przy wydobyciu surowca pracę mieliby znaleźć Grenlandczycy ${ }^{15}$. Spotkało się to ze zdecydowaną rekcją rządu w Kopenhadze, która odpowiada za dziedzinę związaną z obronnością. Duńczycy obawiali się rezultatów debaty na temat wycofania się Grenlandczyków z porozumienia o zakazie wydobycia na wyspie pierwiastków promieniotwórczych, jaką przeprowadził rząd grenlandzki. Jednocześnie została ujawniona analiza prawna sporządzona dla rządu w Nuuk, której konkluzja przedstawiała się w taki sposób, że Grenlandia posiada prawo wydobycia uranu, o ile nie będzie on wykorzystywany dla celów militarnych. Mimo to Kopenhaga odwołuje się do swych prerogatyw związanych z obronnością, negatywnie odno-

14 Grenlandia pozwala u siebie kopać $i$ wiercić. Koniec z polityka „zero tolerancji” dla uranu, https://www.tvn24.pl/wiadomosci-ze-swiata,2/grenlandia-pozwala-u-siebie-kopac-i-wiercic-koniec-z-polityka-zero-tolerancji-dla-uranu,365998.html [dostęp: 10.12.2019].

15 Ibidem. 
sząc się do tego pomysłu. I choć początkowo premier Danii Helle Thorning-Schmidt używała stonowanych wypowiedzi typu: „Uran w sposób oczywisty jest dobrem szczególnym i przez to powinna być zawarta w tej kwestii specjalna umowa pomiędzy nami a Grenlandią" ${ }^{16}$, to już szef duńskiej Akademii Obrony, kontradm. Nils Wang, kategorycznie stwierdził, iż owa sytuacja „(...) doprowadziła do konfrontacji duńsko-grenlandzkiej"17.

Sytuację zaognił fakt, iż Grenlandczycy we wrześniu 2013 r. opublikowali raport, w którym stwierdzili, iż posiadają wyłączne prawo do zarządzania surowcami znajdującymi się na terytorium wyspy. Jeszcze w tym samym miesiącu doszło do spotkania premierów Danii i Grenlandii, które dodatkowo wskazało na kolizyjne interesy rządów obu części tworzących Królestwo Danii. Wyrazem tego były słowa duńskiej premier, iż „zgodziliśmy się, że się ze sobą nie zgadzamy”18.

Mimo protestów ekologów, grenlandzki rząd przegłosował w październiku 2013 r. ustawę dotyczącą możliwości wydobycia uranu, co przesądziło o wyniku konfrontacji. Jednak rozmowy międzyrządowe w kwestiach związanych z eksploatacją promieniotwórczego pierwiastka trwały nadal. Rezultatem tego było podpisanie porozumienia o współpracy w tym względzie między rządem duńskim a rządem Grenlandii. Jednocześnie nie zmniejszyło to napięcia między stronami, czego wyrazem były słowa premier Grenlandii, które padły przy tej okazji: „Chcemy współpracować, ale Dania musi zrozumieć,

16 Spór o uran na Grenlandii, http://www.elektroonline.pl/news/6942,Spor-o-uran-na-Grenlandii [dostęp: 10.12.2019].

17 Konflikt o grenlandzki uran: Dania boi się eksploatacji surowca, https://forsal.pl/artykuly/732404,konflikt-o-grenlandzki-uran-dania-boi-sie-eksploatacji-surowca.html [dostęp: 10.12.2019].

18 Spór o uran na Grenlandii, http://www.elektroonline.pl/news/6942,Spor-o-uran-na-Grenlandii [dostęp: 11.12.2019]. 
że to my mamy wyłączne prawo do uranu na naszym terytorium, w tym do decydowania o jego wydobyciu" ${ }^{19}$.

Innym przykładem sytuacji konfliktowej na linii rząd Grenlandii - rząd duński było utworzenie przez ten pierwszy pozycji w swym budżecie na 2014 r. przewidującej przeznaczenie części pieniędzy na utworzenie własnego przedstawicielstwa w stolicy Stanów Zjednoczonych, Waszyngtonie. Według duńskich mediów owa aktywność miałaby na celu nawiązanie kontaktów z Amerykanami bez pośrednictwa Duńczyków (którzy de facto są odpowiedzialni za prowadzenie polityki zagranicznej) chcąc w oparciu o tę relację spróbować lepiej rozgrywać swoje interesy z rządem w Kopenhadze ${ }^{20}$. Poza tym ów ruch Grenlandczyków jest jasnym sygnałem podważającym prerogatywę przynależną Danii do prowadzenia w jej imieniu polityki międzynarodowej. Stanowi informację o ciągłych aspiracjach Grenlandczyków do osiągnięcia większej niezależności i być może jest próbą sondującą zachowanie rządu duńskiego na tego typu działania.

Kolejną aktywnością wywołującą napięcia na linii Nuuk-Kopenhaga jest działalność Grenlandczyków związana $\mathrm{z}$ wydawaniem pozwoleń Chińczykom na prowadzenie wydobycia surowców na Grenlandii. Jednocześnie, aby móc prowadzić intensywniej owe prace Chińczykom były potrzebne lotniska, na których wybudowanie otrzymały zgodę.

Ta infrastruktura sama w sobie nie jest zagrożeniem, aczkolwiek z obronnego punktu widzenia zyskuje zastrzeżenia. W związku z tym, iż Dania odpowiada za sprawy obronności i jest członkiem NATO, udostępniła ową wyspę Amerykanom

19 Ibidem.

20 Grenlandia niepodległa? Dania zaniepokojona planami wyspy, https://wiadomosci.dziennik.pl/swiat/artykuly/444086, grenlandia-oderwie-sie-od-danii-kopenhaga-zaniepokojona.html [dostęp: 11.12.2019]. 
w ramach Sojuszu Północnoatlantyckiego, aby rozmieścili na niej swe bazy. Jednak w chwili, gdy Grenlandia uzyskałaby niepodległość, to automatycznie wkład Danii do NATO zmniejszyłby się diametralnie poprzez utratę strategicznie umiejscowionej wyspy, a na dodatek w Pakcie Północnoatlantyckim wytworzyłaby się „wyrwa”, którą mogliby przejąć Chińczycy. Taka możliwość jest realna z uwagi na fakt, iż już raz Duńczycy zapobiegli wykupieniu bazy morskiej opuszczonej przez Stany Zjednoczone w 2016 r.

Jednak Dania ma ograniczone możliwości, aby zapobiegać prochińskiej polityce Grenlandii. Pozostaje im jedynie wyrażanie swej opinii i to w nieoficjalny sposób, jak to zrobił anonimowo jeden z duńskich przedstawicieli rządu dla agencji informacyjnej, komentując, że „Chiny nie mają nic do szukania na Grenlandii”"21. Owo działanie stanowi wyraz ciągłego dążenia do niepodległości Grenlandczyków, czemu de facto Dania nie może się przeciwstawić, ponieważ zostało to ujęte w dokumencie z 2009 r. poszerzającym autonomię, która zezwala mieszkańcom Grenlandii na odłączenie się w chwili, gdy uznają, że są na to gotowi ${ }^{22}$.

\section{Możliwe scenariusze rozwoju sytuacji w regionie wpływające na tamtejsze bezpieczeństwo}

\section{1) Zachowanie obecnego statusu quo}

Pierwszym scenariuszem, jaki może zostać zrealizowany jest zachowanie istniejącego status quo, czyli pozostawienie

21 P. Jendroszczyk, Grenlandia to nie Katalonia, https://www. rp.pl/Polityka/304259907-Grenlandia-to-nie-Katalonia.html [dostęp: 11.12.2019].

22 Ibidem. 
Grenlandii w ramach autonomicznej części państwa duńskiego. Choć na Grenlandii mocno odczuwane są nastroje niepodległościowe, to jednak należy zauważyć, że najbardziej prawdopodobną opcją w obecnym czasie będzie pozostawienie otwartą kwestii secesji od Królestwa Danii. Jest to podyktowane w głównej mierze pragmatyką, bowiem Grenlandia nie byłaby w stanie udźwignać samodzielnie kwestii finansów państwa ${ }^{23}$. Olbrzymie ilości zasobów naturalnych, które znajdują się na jej terytorium nie mogą być póki co eksploatowane ze względu na trudny dostęp do nich oraz wysokie koszty wydobycia. Poza tym pojawiły się badania naukowców, które dowodzą, iż nawet ta szacowana ilość znajdujących się tam surowców nie wystarczyłaby na swobodną i bezproblemową egzystencję Grenlandczyków. Do tego szacuje się, iż dopiero za dwadzieścia lat Grenlandia mogłaby osiągnąć odpowiedni poziom pozwalający na samodzielnośćc ${ }^{24}$

Ponadto Grenlandia nie dysponuje liczną wysoko wykwalifikowaną kadrą pracowników. Dodać należy, że w sytuacji gdy populacja Grenlandczyków wynosi niecałe 60 tys. ludzi, czyni to ryzykownym, aby sprowadzić na terytorium wyspy większą ilość pracowników zagranicznych, co mogłoby zachwiać strukturą narodowościową i społeczną. W dodatku olbrzymi obszar wyspy w odniesieniu do tak małej liczby ludności byłby w większości niezagospodarowany

23 Ch. Opitz, T. Etzold, Grenlandia: Dążenie do niezależności bez uwzględnienia podstaw ekonomicznych, https://www.euractiv.pl/section/ polityka-wewnetrzna-ue/opinion/grenlandia-dazenie-do-niezaleznosci-bez-uwzglednienia-podstaw-ekonomicznych/ [dostęp: 10.01.2020].

24 A. Touriel, Les ressources naturelles du Groenland ne suffiraient pas à son autonomie, https://www.euractiv.fr/section/developpement-durable/news/les-ressources-naturelles-du-groenland-ne-suffiraient-pas-ason-autonomie/ [dostęp: 10.01.2020]. 
i kusiłby inne państwa chęcią jej zagospodarowania bądź przejęcia $^{25}$.

Odnosząc się zaś do kwestii twardego bezpieczeństwa, to zachowanie Grenlandii w ramach Danii będzie dawało ochronę tej części euroatlantyckiego regionu sprawowaną przez Marynarkę Wojenną Królestwa Danii oraz sojuszniczą obecność wojsk Stanów Zjednoczonych rozmieszczonych tam w ramach NATO. Grenlandia nie posiada samodzielnych jednostek wojskowych mogących zagwarantować bezpieczeństwo całej wyspie i prowadzić kontrolę nad należącym do niej obszarem morskim, co też skłania ku pozostaniu przy państwie duńskim posiadającym środki i cieszącym się autorytetem $\mathrm{w}$ regionie arktycznym ${ }^{26}$.

\section{2) Uzyskanie niepodległości przez Grenlandię i wejście pod kuratelę USA}

Kolejnym scenariuszem jest uzyskanie niepodległości przez Grenlandię i jej przejście pod kuratelę Stanów Zjednoczonych. Jest to możliwy scenariusz działań Grenlandczyków, mając na uwadze przedstawiony w artykule konflikt toczący się od wielu lat między nimi a Duńczykami. Sama świadomość swej odrębności kulturowej oraz tożsamości narodowej uzasadnia podjęcie kroków zmierzających do secesji od Królestwa Danii. Ponadto grenlandzkiemu społeczeństwu obce są problemy oddalonej o tysiące kilometrów macierzy i zamieszkującej ją ludności duńskiej. W dodatku chęć sa-

25 Le Danemark réagit vivement aux visées américaines sur le Groenland, https://www.euractiv.fr/section/all/news/le-danemark-reagit-vivement-aux-visees-americaines-sur-le-groenland/ [dostęp: 10.01.2020].

26 Duński wywiad ostrzega przed konfliktem mocarstw na Grenlandii, https://www.tvp.info/45564599/dunski-wywiad-ostrzega-przed-konfliktem-mocarstw-na-grenlandii [dostęp: 10.01.2020]. 
mostanowienia we własnych sprawach i niechęć w kwestii dzielenia się zyskami z wydobywanych surowców znajdujących się na wyspie sugeruje słuszność działań prowadzących do uzyskania niepodległości.

Jednocześnie Grenlandia uzyskując niepodległość nie będzie posiadała własnych sił zbrojnych, natomiast „odziedziczy" na swym terytorium wojskowe bazy amerykańskie utworzone tam za zgodą rządu w Kopenhadze. Taka sytuacja będzie wymagała ratyfikowania nowych umów międzynarodowych, ponieważ trudno oczekiwać, aby Stany Zjednoczone chciały dobrowolnie opuścić terytorium wyspy. Byłoby to nie do przyjęcia ze strategicznego punktu widzenia Amerykanów, ponieważ obszar Grenlandii jest położony nieopodal wschodniego wybrzeża Stanów Zjednoczonych, skąd bliżej i łatwiej byłoby prowadzić akcje wywiadowcze czy atak na $\mathrm{USA}^{27}$. Z kolei Grenlandczycy nieposiadający własnej armii będą niejako zmuszeni do podporządkowania się silniejszemu sąsiadowi, który de facto będzie znajdował się na ich terytorium dysponując siłą militarną.

Wartością dodatnią tej sytuacji dla Grenlandii będzie uzyskanie ochrony. Jednak prawdopodobnie odbyłoby się to kosztem wasalizacji wobec silniejszego sąsiada i ponowną utratą suwerenności w kontekście podejmowania decyzji przez rząd w Nuuk związanych z polityką zagraniczną i wewnętrzną, jeśli chodzi o wystawianie koncesji na poszukiwanie i wydobycie surowców energetycznych ${ }^{28}$.

27 Ile trzeba bytoby zaptacić za Grenlandię? Kwota może sięgać bilionów dolarów, https://businessinsider.com.pl/wiadomosci/grenlandia-ile-kosztowalby-zakup-panstwa-od-danii/wmzlbjv [dostęp: 15.01.2020].

D. Walewska, Grenlandia: obiekt pożądania Trumpa, największa wyspa świata, https://www.rp.pl/Gospodarka/308229865-Grenlandia-Obiekt-pozadania-Trumpa-najwieksza-wyspa-swiata.html [dostęp: 15.01.2020]. 


\section{3) Uzyskanie niepodległości przez Grenlandię i wejście pod kuratelę Chin}

Trzecim scenariuszem rozwoju sytuacji wynikającej ze sporu między Grenlandczykami a Duńczykami o samorządność Grenlandii jest uzyskanie niepodległości przez Grenlandię i przejście tego nowo powstałego państwa pod zależność państwa chińskiego. Jest to możliwy scenariusz do zrealizowania, ponieważ przesłanki polegające na istniejących niesnaskach między społeczeństwami duńskim i grenlandzkim związanych z brakiem integracji między nimi są rezultatem niezrozumienia siebie nawzajem, wynikającego z zamieszkiwania innych, odległych regionów oraz ze zmierzania się na co dzień z innymi problemami. Ponadto kwestią sporną rozpalającą wyobraźnię Grenlandczyków jest chęć dysponowania tamtejszymi surowcami bez partycypacji Duńczyków. Osiągnięcie niepodległości od Kopenhagi uwolniłoby mieszkańców Grenlandii od tych spraw.

Jednocześnie pojawiłyby się nowe szanse i zagrożenia $\mathrm{z}$ tego wynikające. Polegałyby one na tym, że obecnie rząd w Nuuk wydał wiele koncesji na wydobywanie surowców Chińczykom. A nieposiadając dość licznej i wykwalifikowanej kadry musiałby sprowadzić więcej pracowników, chcąc podnieść profity z eksploatacji zasobów naturalnych. Chiny $\mathrm{z}$ kolei to mocarstwo światowe, które m.in. posiada monopol na wydobycie i eksport metali rzadkich, których duża ilość znajduje się na terytorium Grenlandii. Ponadto polityka chińska skierowana została w ostatnich latach na uzyskanie jak największych wpływów w regionie arktycznym. Chiny są od 2013 r. obserwatorem w Radzie Arktycznej. 
Stocznie chińskie budują lodołamacze pozwalające na żeglugę arktyczną drogą morską. Od 2012 r. ChRL współpracuje z Islandią w ramach poszukiwania i wydobycia surowców na islandzkich wodach arktycznych ${ }^{29}$. W 2018 r. zaś Chińczycy stworzyli swoją strategię dotyczącą Arktyki, w której chcieliby zagospodarować jej obszar poprzez poprowadzenie przez tamtejsze wody Polarnego Jedwabnego Szlaku ${ }^{30}$.

Owe działania i plany wskazują na ekspansjonistyczną politykę Chin, a w związku ze słabością nowo powstałego państwa Grenlandii mogłyby to wykorzystać dla zrealizowania własnych celów, przede wszystkim gospodarczych. Sprowadzając Chińczyków do pracy, Grenlandczycy uzyskaliby większe dochody. Jednak ze względu na małą liczebność rodzimej populacji mogliby doprowadzić do zachwiania jej struktury poprzez przybycie pracowników zza granicy. Poza tym owe braki uzależniłyby rząd w Nuuk od pomocy gospodarczej z zewnątrz, a coraz większa ekspansja gospodarcza Chin doprowadziłaby do szybkiego uzależnienia się od nich Grenlandii. Na dodatkową uwagę zasługuje fakt, iż Chińczycy przez swą konsekwentną politykę już teraz dążą do coraz większej i mocniejszej obecności na tym obszarze, czego dowodem była udaremniona przez rządy USA i Danii próba otrzymania zgody na budowę trzech lotnisk na Grenlandii. Wobec powyższego kwestią czasu byłoby uzależnienie się rządu w Nuuk od Chin ${ }^{31}$.

29 L.K. Sadurski, Surowce Arktyki w politykach energetycznych państw Azji Wschodniej i Południowej, [w:] Bezpieczeństwo energetyczne wyzwaniem XXI wieku - edycja druga, red. Z. Lach, Warszawa 2014, s. 138-140.

30 A.M. Kamińska, Grenlandia i wielka gra mocarstw w Arktyce. USA kontra Chiny i Rosja, https://www.polskieradio24.pl/5/1223/Artykul/2357769,Grenlandia-i-wielka-gra-mocarstw-w-Arktyce-USA-kontraChiny-i-Rosja [dostęp: 18.01.2020].

31 P. Stępiński, Czy Trump kupi Grenlandię?, https://biznesa- 


\section{Wnioski}

Grenlandczycy, to naród zamieszkujący wielką wyspę. Nigdy nie posiadali własnego państwa żyjąc pod panowaniem obcych rządów i królestw pochodzących z zewnątrz. I choć nie stanowią licznej grupy, to postanowili się skonsolidować, by móc razem zadbać o własną przyszłość. Idea samostanowienia Grenlandczyków pojawiła się stosunkowo niedawno, bo w II poł. XX w. Sprzyjała mu naturalna regionalizacja obszaru jaki zamieszkują oraz możliwość zrzeszania się autochtonów w organizacjach, w których mogą się rozwijać. Pomysł ten pozwolił Grenlandczykom zaczać myśleć, iż oni, jako naturalni mieszkańcy tego terytorium, ponoszą za nie odpowiedzialność oraz za samych siebie.

Świadomość polityczna jaka się pojawiła wraz z ideą samostanowienia pozwala dążyć do realizacji własnych celów związanych m.in. z takimi kwestiami, jak podział władzy, współdecydowanie o wydobyciu surowców czy kierunkach rozwoju. Idea samostanowienia jest związana z poczuciem własnej wartości, z tym że potrafią sami zadbać o swój los. Grenlandczycy nie chcą już być poddanymi królowej Małgorzaty II. Stąd też konsekwentnie czynione przez nich kroki, zmierzające najpierw do uzyskania autonomii w ramach Królestwa Danii i później stopniowego poszerzania jej zakresu, który na dzień dzisiejszy określa ich język jako urzędowy, pozwalają na samodzielne decydowanie w kwestiach gospodarki surowcowej czy wreszcie zapis uznający Grenlandczyków przez Duńczyków jako naród i dający

lert.pl/trump-zakup-grenlandia-energetyka-bezpieczenstwo/ [dostęp: 18.01.2020]. 
możliwość secesji w momencie, jaki mieszkańcy Grenlandii uznają za stosowny.

Jednakowoż idea samostanowienia Grenlandczyków stanowi problem w relacjach z Kopenhagą, ponieważ stwarza ryzyko odłączenia się zasobnej w surowce, strategicznie położonej w świecie części państwa. Poza tym byłaby to dla Duńczyków strata wizerunkowa redukująca ich królestwo do niewielkiego obszaru w Europie. Dodatkowo Dania utraciłaby kontakt z Arktyką jako regionem i przestałaby się liczyć na regionalnej arenie międzynarodowej.

Chęć samostanowienia Grenlandczyków generuje konflikty, ponieważ następuje w tej kwestii walka o władzę nad częścią terytorium państwa. Duńczycy, chcąc utrzymać wyspę przy sobie, musieli zgadzać się na stopniowe oddawanie jej autochtonom. I choć obecnie wydawałoby się, że w relacjach duńsko-grenlandzkich powinien zapanować spokój, z uwagi na oddanie bardzo szerokich uprawnień nad wyspą rządowi w Nuuk, to jednak idea samostanowienia Inuitów grenlandzkich stanowi siłę, która niejako pcha ich nawet do łamania dotychczasowych ustaleń, zgodnie z którymi nie powinni otwierać własnego przedstawicielstwa w innym państwie. Z kolei z drugiej strony Duńczycy, choć zezwolili na samodzielną politykę surowcową Grenlandczykom, to starają się ingerować w nią szukając pretekstu związanego $\mathrm{z}$ pozostającymi w ich gestii prerogatywami dotyczącymi obronności, chcąc w ten sposób narzucić własną wolę.

Patrząc z szerszej perspektywy, konflikt grenlandzko-duński wpływa na bezpieczeństwo w wymiarze regionalnym, a dokładnie rzecz ujmując - na bezpieczeństwo w euroatlantyckiej części Arktyki. Dzieje się tak z uwagi na fakt, iż Grenlandia jest położona w strategicznie ważnym geograficznie miejscu, które stanowi kluczowe ogniwo w sys- 
temach bezpieczeństwa zbiorowego państw zachodnich mających odzwierciedlenie w zrzeszającej je organizacji NATO. Położenie to jest ważne także ze względu na ekonomiczne powiązania między Unią Europejską a Kanadą i Stanami Zjednoczonymi. Zgodnie z tym każdy duży konflikt pomiędzy rządami Nuuk i Kopenhagi nie służy zachowaniu spokoju w tym regionie. Jest to spowodowane chęcią wykorzystania tych niesnasek przez mocarstwa globalne, takie jak USA i Chiny, które realizują tam swoje interesy.

Dalsze napięcia o podłożu niepodległościowym mogą skutkować zbyt wczesnym odłączeniem się Grenlandii od Królestwa Danii, w momencie gdy Grenlandczycy nie będą na to całkowicie przygotowani. Obecnie nie byliby w stanie pokryć kosztów socjalnych funkcjonowania państwa, zrównoważyć poziomu dotacji duńskiej. Poza tym borykają się z małą liczbą ludności w stosunku do powierzchni wyspy jaką musieliby zagospodarować, brakiem wykwalifikowanej kadry potrafiącej zarządzać polityką surowcową oraz brakiem odpowiednich sił zapewniających bezpieczeństwo wewnętrzne i zewnętrzne. Taka sytuacja stworzyłaby tzw. „próżnię bezpieczeństwa", która zapewne zostałaby szybko zagospodarowana przez silniejsze państwa. W ten sposób Grenlandia z powrotem utraciłaby suwerenność - tym razem na rzecz światowego hegemona, który zapewne nie podchodziłby tak ochoczo do kwestii współpracy i ustępstw jak rząd Danii. Choć oficjalnie Grenlandia byłaby niepodległym państwem.

Pierwszy scenariusz rozwoju sytuacji, polegający na zachowaniu obecnego stanu bez zmian, jest najkorzystniejszą opcją pod względem bezpieczeństwa, ponieważ nie zmienia architektury istniejących systemów bezpieczeństwa w tym regionie. Niepodległość Grenlandii skutkowałaby usunięciem Danii z grona państw arktycznych i przemeblowaniem 
organizacji oraz forów działających na rzecz współpracy i rozwoju Arktyki, zastępując ją członkostwem Grenlandii. Państwo to ze względu na swój obecny potencjał bardziej byłoby szukającym wsparcia niż dyktującym warunki i przez to obniżyłby się poziom bezpieczeństwa w całym kompleksie regionalnym. Scenariusz zachowania obecnego status quo wydaje się być jak na razie najlepszą opcją dla bezpieczeństwa regionalnego i mającą największą szansę realizacji.

Drugi scenariusz, dotyczący uzyskania niepodległości przez Grenlandię, skutkowałby pojawieniem się w regionie państwa o słabym potencjale militarnym, gospodarczym (mimo posiadanych złóż surowców) i ludnościowym. Ze względu na bliskość Stanów Zjednoczonych, ich strategiczne interesy oraz posiadanie na terytorium Grenlandii baz wojskowych, bardzo prawdopodobne byłoby działanie Waszyngtonu zmierzające do podporządkowania sobie tej wyspy. Wobec tego Grenlandia na powrót utraciłaby możliwość swobodnego decydowania o sobie, choć z drugiej strony zyskałaby silnego protektora, który jednak nie musiałby chcieć liczyć się z głosem społeczeństwa grenlandzkiego.

W szerszym ujęciu, euroatlantycki region Arktyki mógłby podnieść potencjał bezpieczeństwa przez głębsze wejście mocarstwa jakim są Stany Zjednoczone. Chociaż z drugiej strony musiałyby one zaangażować więcej swoich sił na tym obszarze, na co niekoniecznie byłoby je stać. Najprawdopodobniej skończyłoby się to wycofaniem swych sił z innego, nie mniej ważnego dla interesów USA, regionu świata. Z drugiej strony przejście Grenlandii spod władzy zwierzchniej Danii pod kuratelę USA mogłoby wywołać konflikty z innymi państwami regionu, obawiającymi się chęcią zdobycia większych wpływów w Arktyce przez Stany Zjednoczone. Dodatkowo wycofany stamtąd potencjał militarny Danii, bądź co bądź 
członka NATO, przyczyniłby się do zmniejszenia znaczenia funkcjonującego w euroatlantyckiej części Arktyki Organizacji Traktatu Północnoatlantyckiego i mógłby skutkować obniżeniem poziomu bezpieczeństwa w regionie (ze względu na niewystarczające siły amerykańskie).

Następną konsekwencją objęcia Grenlandii wpływami Stanów Zjednoczonych byłoby „zamknięcie” Kanady wewnątrz amerykańskiej strefy wpływów poprzez geograficzne otoczenie jej z trzech stron i rozgrywania tego w kontekście wykorzystania wód arktycznych jako arterii żeglugowej skracającej drogę morską między Europą a Azją. Otoczenie Kanady skutkowałoby posiadaniem wpływu USA na oba wejścia Przejścia Północno-Zachodniego, od strony wschodniej (gdzie u jego ujścia jest Grenlandia) i zachodniej (gdzie u jego ujścia jest Alaska), blokując aktywność kanadyjską zmierzającą do uznania przez społeczność międzynarodową tej drogi morskiej za wody wewnętrzne Kanady. Taka sytuacja byłaby problemem dla rządu w Ottawie, co zapewne generowałoby konflikty w regionie arktycznym, a to mogłoby się przełożyć na spadek współpracy w ramach NATO i sprzyjać osłabieniu tego kolektywu.

Z kolei trzeci scenariusz, polegający na uzyskaniu niepodległości przez Grenlandię i wejście jej w chińską strefę wpływów ze względu na ich wspólne powiązania gospodarcze również miałby niebagatelny wpływ na poziom bezpieczeństwa w euroatlantyckiej części Arktyki. Jednak byłby on najtrudniejszy do zrealizowania w obecnej chwili. Biorąc pod uwagę kwestie twardego bezpieczeństwa, mogłoby to stanowić duże zagrożenie dla interesów Stanów Zjednoczonych ze względu na ich bliskie sąsiedztwo. Dodatkowo po ogłoszeniu niepodległości Grenlandia musiałaby stawić czoła problematycznej sytuacji, gdzie na jej terytorium stacjo- 
nowałyby wojska amerykańskie, a jednocześnie Chińczycy mogliby również prowadzić różne operacje wojskowe przeciwko USA wykorzystując tamtejszą infrastrukturę.

Stając się teatrem takich działań Grenlandia nie mogłaby korzystać z pełnej niezależności, a dodatkowo bezpieczeństwo regionalne na tamtym obszarze byłoby zagrożone poprzez powstanie u wybrzeży Stanów Zjednoczonych nowego ogniska sporów, które mogłyby doprowadzić do eskalacji napięcia między dwoma światowymi mocarstwami w Arktyce. Ponadto coraz większa obecność Chin na Grenlandii nie obyłaby się bez skupienia uwagi innych państw arktycznych, zwłaszcza tych skupionych w ramach NATO. Strategiczne położenie wyspy pomiędzy Ameryką Północną a Europą na północy sięgając Arktyki stanowiącej najkrótszą drogę morską oraz powietrzną między Azją a Ameryką Północną decyduje o możliwościach wywierania wpływu przez tamtejsze państwa względem siebie. Między Rosją a USA i Kanadą z jednej strony, między Stanami Zjednoczonymi i Kanadą a państwami Europy Zachodniej z drugiej strony. Grenlandia pod protektoratem chińskim stanowiłaby „wyłom” w strukturze systemu Organizacji Traktatu Północnoatlantyckiego a zarazem prowadziłaby do obniżenia poziomu bezpieczeństwa w samym środku euroatlantyckiego regionu ze względu na sprzeczne interesy chińskie i państw zachodnich.

Wchodząc pod protekcję Chin Grenlandia stałaby się niejako „koniem trojańskim” w samym sercu zachodniej struktury bezpieczeństwa ekonomiczno-militarnego, dając pretekst rządowi w Pekinie do ingerencji w tym regionie, co skutkowałoby rozsadzaniem dotychczas spójnej struktury bezpieczeństwa w tej części świata.

Konflikt duńsko-grenlandzki o samorządność Grenlandii ma wpływ na bezpieczeństwo w euroatlantyckiej części Ark- 
tyki. Toczenie dalszych sporów między tymi stronami będzie prowadziło tylko do wzrostu napięcia po każdej z nich. Najlepszym rozwiązaniem byłoby trzymanie się zapisów dokumentu z 2009 r. poszerzającego autonomię Grenlandczykom bez prób przekraczania ich przez którąkolwiek ze stron czy szukania pretekstów do okazania własnego stanowiska jako słusznego. Zalecany byłby dialog w kwestiach mogących wywoływać spór. Zmiany klimatu i rozwój technologii wydobywczej w Arktyce doprowadzą zapewne w przyszłości do pełnego usamodzielnienia się Grenlandii. Jeśli jednak Dania obawia się kwestii związanych z obronnością, to powinna czynić starania, by na wyspie znajdowali się ludzie rozumiejący ten problem i byli na tyle wykształceni, aby móc poradzić sobie w meandrach światowej polityki. Jest to też kwestia do rozwiązania dla samych Grenlandczyków, by nie zachłysnęli się wizją uzyskanej niepodległości i nie posiadając stosownych umiejętności, stać się łatwym łupem dla mocarstw globalnych de facto wchodząc samemu pod obce panowanie. Takie działanie wygeneruje tym samym jeszcze większe problemy - tym razem na arenie międzynarodowej skutkujące pojawieniem się silniejszych konfliktów, tym razem między państwami, co przyczyni się do zaognienia stosunków między nimi i obniżeniem poziomu bezpieczeństwa w regionie, czego konsekwencje odczują sami Grenlandczycy.

\section{Bibliografia}

Barkham P., Niepodlegtość na Grenlandii?, https://www.polityka.pl/tygodnikpolityka/swiat/279999,1,niepodleglosc-dla-grenlandii.read.

CIA Factbook, https://www.cia.gov/library/publications/ the-world-factbook/geos/gl.html. 
Duński wywiad ostrzega przed konfliktem mocarstw na Grenlandii, https://www.tvp.info/45564599/dunski-wywiad-ostrzega-przed-konfliktem-mocarstw-na-grenlandii.

Grenlandia niepodległa? Dania zaniepokojona planami wyspy, https://wiadomosci.dziennik.pl/swiat/artykuly/444086,grenlandia-oderwie-sie-od-danii-kopenhaga-zaniepokojona.html.

Grenlandia pozwala u siebie kopać $i$ wiercić. Koniec z polityka „zero tolerancji” dla uranu, https://www.tvn24.pl/ wiadomosci-ze-swiata, 2/grenlandia-pozwala-u-siebie-kopac-i-wiercic-koniec-z-polityka-zero-tolerancji-dla-uranu,365998.html.

Ile trzeba bytoby zaptacić za Grenlandię? Kwota może sięgać bilionów dolarów, https://businessinsider.com.pl/wiadomosci/grenlandia-ile-kosztowalby-zakup-panstwa-oddanii/wmzlbjv.

Irząbek J., Wyspa chce niepodlegtości, „Polityka”, https://www. polityka.pl/tygodnikpolityka/swiat/250999,1,wyspa-chceniepodleglosci.read?page $=106 \&$ moduleId $=4781$.

Jendroszczyk P., Grenlandia to nie Katalonia, https://www. rp.pl/Polityka/304259907-Grenlandia-to-nie-Katalonia. html.

Kamińska A.M., Grenlandia $i$ wielka gra mocarstw w Arktyce. USA kontra Chiny i Rosja, https://www.polskieradio24.pl/5/1223/Artykul/2357769,Grenlandia-i-wielkagra-mocarstw-w-Arktyce-USA-kontra-Chiny-i-Rosja.

Konflikt o grenlandzki uran: Dania boi się eksploatacji surowca, https://forsal.pl/artykuly/732404,konflikt-o-grenlandzki-uran-dania-boi-sie-eksploatacji-surowca.html. Lach Z. (red.), Bezpieczeństwo energetyczne wyzwaniem XXI wieku - edycja druga, Warszawa 2014. 
Le Danemark réagit vivement aux visées américaines sur le Groenland, https://www.euractiv.fr/section/all/news/ledanemark-reagit-vivement-aux-visees-americaines-sur-le-groenland/.

Łuszczuk M. (red.), Arktyka na początku XXI wieku. Między rywalizacją a wspótpraca, Lublin 2013.

Opitz Ch., Etzold T., Grenlandia: Dążenie do niezależności bez uwzgleddnienia podstaw ekonomicznych, https:// www.euractiv.pl/section/polityka-wewnetrzna/opinion/ grenlandia-dazenie-do-niezaleznosci-bez-uwzglednienia-podstaw-ekonomicznych/.

Spór o uran na Grenlandii, http://www.elektroonline.pl/ news/6942,Spor-o-uran-na-Grenlandii.

Stępiński P., Czy Trump kupi Grenlandię?, https://biznesalert.pl/trump-zakup-grenlandia-energetyka-bezpieczenstwo/.

Symonides J., Arktyka - region wspótpracy czy konfliktów, „Stosunki Międzynarodowe” 2011, nr 3-4 (44).

Szymborski W., Międzynarodowe stosunki polityczne, Bydgoszcz 2012.

Touriel A., Les ressources naturelles du Groenland ne suffiraient pas à son autonomie, https://www.euractiv.fr/ section/developpement-durable/news/les-ressources-naturelles-du-groenland-ne-suffiraient-pas-a-son-autonomie/.

Walewska D., Grenlandia: obiekt pożadania Trumpa, największa wyspa świata, https://www.rp.pl/Gospodarka/308229865-Grenlandia-Obiekt-pozadania-Trumpa-najwieksza-wyspa-swiata.html. 


\begin{abstract}
Abstrakt
Dania jest państwem arktycznym dzięki swemu terytorium autonomicznemu - Grenlandii, która stanowi część Arktyki. Na wyspie tej znajdują się złoża kopalne, głównie zasoby metali rzadkich. Odkrycie ich w tamtym miejscu pobudziło Grenlandczyków do mocniejszego wyrażania chęci oddzielenia sie od metropolii. Natomiast Dania, poprzez dostęp do Arktyki, dąży do zapewnienia sobie bezpieczeństwa energetycznego i prowadzenia międzynarodowej polityki tworzącej arktyczne środowisko bezpieczeństwa.

Jednocześnie Grenlandia stanowi ważny komponent dla bezpieczeństwa euroatlantyckiego w regionie arktycznym. To skutek znajdowania się Królestwa Danii w NATO. Konflikt na linii Nuuk-Kopenhaga wpływa na współczesny poziom bezpieczeństwa w tym regionie. Daje on m.in. możliwość wykorzystywania tychże napięć przez Chiny biorące udział w eksploatacji surowców na wyspie.

Celem wystąpienia jest przedstawienie tego konfliktu i tego jaki niesie wpływ na współczesne bezpieczeństwo w euroatlantyckiej części Arktyki. Do osiągnięcia celu wykorzystano metodę badawczą porównawczą, aby porównać stanowisko duńskie z grenlandzkim, metodę historyczną w odniesieniu do okresu przedstawionego zagadnienia przypadającego na lata 2009-2018 oraz metodę prognostyczną, wykorzystaną do pokazania możliwych scenariuszy rozwoju sytuacji w regionie.

Wnioski z badań pokazują, iż relacje między Duńczykami a Grenlandczykami są konfliktogenne. Spory między tymi nacjami są wykorzystywane przez USA i Chiny, które chcą realizować własne interesy w Arktyce. Oddziaływanie konfliktu wpływa negatywnie na bezpieczeństwo $\mathrm{w}$ regionie, sprzyjając rozpadowi istniejącej tam struktury NATO.
\end{abstract}

Słowa kluczowe: Dania, Grenlandia, Arktyka, konflikt, bezpieczeństwo, NATO

\begin{abstract}
Denmark is an Arctic state thanks to its autonomous territory, Greenland, which is part of the Arctic. The island has fossil deposits, mainly of rare metals. The discovery of these deposits there has prompted the Greenlanders to express more strongly their desire
\end{abstract}


to separate themselves from the metropolis. By contrast, Denmark, through access to the Arctic, is seeking to ensure its energy security and to pursue an international policy that creates an Arctic security environment.

At the same time, Greenland is an important component for Euro-Atlantic security in the Arctic region. This is the result of the Kingdom of Denmark being in NATO. The conflict between Nuuk and Copenhagen affects the modern level of security in the region. Among other things, it gives the opportunity for China, which is involved in the exploitation of the island's raw materials, to exploit these tensions.

The aim of the speech is to present this conflict and its impact on modern security in the Euro-Atlantic part of the Arctic. A comparative research method has been used to compare the Danish and Greenlandic positions, a historical method for the period presented for 2009-2018 and a predictive method used to show possible scenarios for developments in the region.

The conclusions of the study show that the relationship between the Danes and the Greenlanders is conflicting. Disputes between these nations are exploited by the USA and China, which want to pursue their own interests in the Arctic. The impact of the conflict has a negative impact on security in the region, encouraging the break-up of the NATO structure that exists there.

Keywords: Denmark, Greenland, Arctic, conflict, security, NATO 